\title{
The emerging health agenda
}

Citation for published version (APA):

Theofilatou, M. (2000). The emerging health agenda: the health policy of the European Community.

[Doctoral Thesis, Maastricht University]. Universiteit Maastricht. https://doi.org/10.26481/dis.20001004mt

Document status and date:

Published: 01/01/2000

DOI:

$10.26481 /$ dis.20001004mt

Document Version:

Publisher's PDF, also known as Version of record

\section{Please check the document version of this publication:}

- A submitted manuscript is the version of the article upon submission and before peer-review. There can be important differences between the submitted version and the official published version of record.

People interested in the research are advised to contact the author for the final version of the publication, or visit the DOI to the publisher's website.

- The final author version and the galley proof are versions of the publication after peer review.

- The final published version features the final layout of the paper including the volume, issue and page numbers.

Link to publication

\footnotetext{
General rights rights.

- You may freely distribute the URL identifying the publication in the public portal. please follow below link for the End User Agreement:

www.umlib.nl/taverne-license

Take down policy

If you believe that this document breaches copyright please contact us at:

repository@maastrichtuniversity.nl

providing details and we will investigate your claim.
}

Copyright and moral rights for the publications made accessible in the public portal are retained by the authors and/or other copyright owners and it is a condition of accessing publications that users recognise and abide by the legal requirements associated with these

- Users may download and print one copy of any publication from the public portal for the purpose of private study or research.

- You may not further distribute the material or use it for any profit-making activity or commercial gain

If the publication is distributed under the terms of Article $25 \mathrm{fa}$ of the Dutch Copyright Act, indicated by the "Taverne" license above, 


\section{The Emerging Health Agenda: The Health Policy of the European Community}




\title{
The Emerging Health Agenda: The Health Policy of the European Community
}

\author{
Proefschrift
}

ter verkrijging van de graad van doctor aan de Universiteit Maastricht, op gezag van de Rector Magnificus, Prof.dr. A.C. Nieuwenhuijzen Kruseman volgens het besluit van het College van Decanen, in het openbaar te verdedigen op woensdag 4 oktober 2000 om 16.00 uur

door

Maria Theofilatou

Geboren op 22 augustus 1962 te Kefallonia 


\section{Promotor:}

Prof.dr. J.A.M. Maarse

\section{Beoordelingscommissie:}

Prof.dr. W.N.J. Groot (voorzitter)

Prof.dr. R. Leidl (Universität Ulm)

Prof.dr. R. ter Meulen

Prof.dr. H.F.L. Nys

Prof.dr. S. Robolis (Panteios University Athens) 
to my parents and to my dear old summer 


\section{PREFACE}

The book aims at developing an analytical framework to explain the role of the EC in health policy matters, the political perspectives and the limitations that underlie it. Public health is a new field of Community policy and this study follows the events until 1998.

It was assumed that Community policy making in the health field would be embedded into Community institutions, rules and policy making practices influencing the manner in which issues emerge, policy is made and the policy making outcomes.

After the general introduction, therefore, the chapters two and three provide with an understanding of the role of the main EC institutions and the rules governing law making and budgeting. Our analysis is completed in chapter four, which addresses the question, what kind of political organisation is the Community?

The remaining four chapters examine the expansion of the Community's health agenda in relation to three main areas of Community action, namely, single market, social policy and research. The selection of these activities should not imply that they form a coherent policy framework. We can only expect that the new Treaty provisions on public health may alter the legacy of an ad hoc and segmented approach into a more institutionalised planned framework to discuss Community health priorities and means for action.

This study was carried out with an EC research training fellowship to the Faculty of Health Sciences of the Maastricht University for September 1993 - February 1995. The Faculty of Health Sciences of the University of Maastricht appointed me as a research fellow for January 1996 - July 1998, in order to enable me to complete my work.

My first debt of gratitude is to my promoter Professor Hans Maarse, who spent a great amount of his time to provide me with guidance. Working with Professor Maarse was for me a great learning, analytical, cultural and human experience.

I am grateful to Ricardo Petrella, who introduced me to the arguments of health technology assessment. I am also grateful to Giovanni Fracchia, with whom I had a fruitful working experience in the field of health services research. I should also record my gratitude to Professor Christa Altenstetter and to Professor Reiner Leidl for helping me with the issues of internal market and health. I should like to give special thanks to my friend Tassos Kanatouris, who followed closely my work, helped me and encouraged me during a very difficult period of my life, if not the most difficult.

Anyone who works on European policy will know how much time and effort can be spent trying to locate (or acquire) books, articles and documents. In this regard, I am grateful to Nikos Papadimitriou responsible of the Greek library of the Commission's translation service. Both the central library of the European Commission and the library of the University of Maastricht were resourceful places. For relevant material, discussions and comments, I am grateful to many people working for the European 
Commission, the European Parliament, the European Social Observatory and the European Public Health Alliance.

For hospitality, political science articles and remarks, I am grateful to my colleagues Jan van de Made and Harm Lieverdink. The same gratitude is expressed for all colleagues and friends at the Department of Health Policy, Organisation and Economics. For providing me with computer support, I am grateful to Jan van Emmerik. For her invaluable help in editing the English manuscript, I should give thanks to Pauline Bickley. 


\section{Overview}

1

General Introduction

2

The Institutions of the Community

3

Community Policy-Making:

Fundamental Political Processes

4

Theories on Community Policy-Making

5

European Community Harmonisation \& Spillovers into Health Regulation

6

Social Security \& Health (care) Systems:

from Harmonisation \& Convergence to the Reality of Monetary Union

7

EC Public Health Activities \& Programmes:

Prevention, Health Information, Education \& Research

8

Conclusions 


\section{Contents}

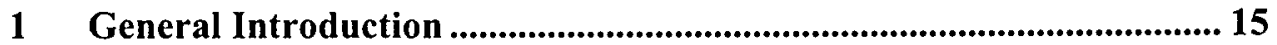

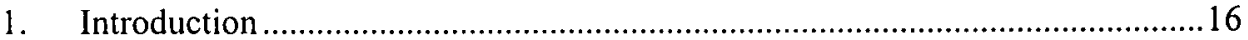

2. Community health policy and healthy Community policy .................................19

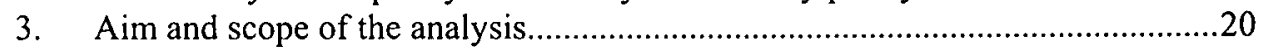

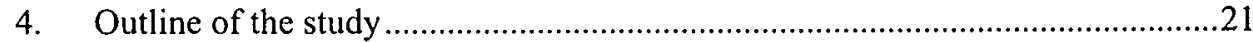

5. Policy and Institutional Framework of the Community...................................24

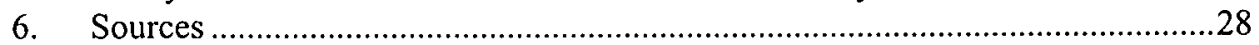

2 The Institutions of the Community................................................... 31

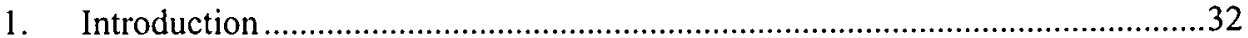

2. The decision-making body: Council of Ministers and the European

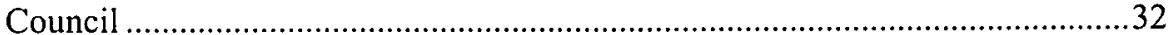

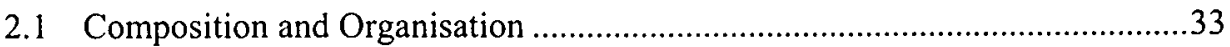

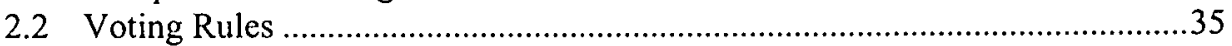

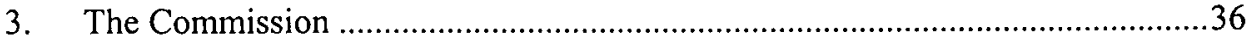

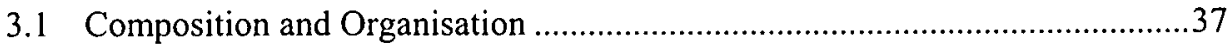

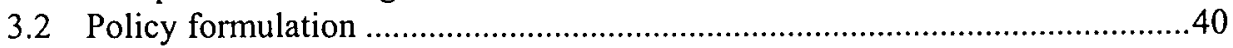

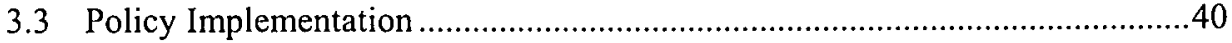

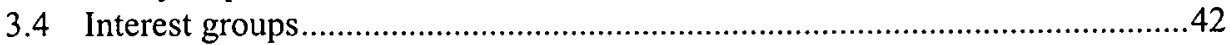

4. The European Parliament.............................................................................44

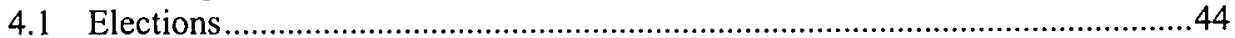

4.2 The European Parliament Party System .......................................................46

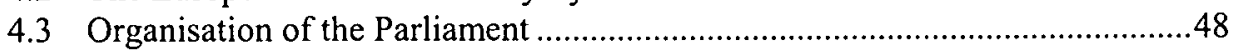

4.4 The role of the Parliament in policy-making ................................................49

5. European Court of Justice and the European Community Legal Order .............51

5. 1 Court of Justice: Powers and Responsibilities...................................................51

5.2 The Court of Justice: Direct applicability, direct effect and primacy of Community Law ..........................................................................................52

5.3 Judicial interpretation: The Court in the European Policy Process...................53

6. Summing up and conclusions ....................................................................5

3 Community Policyu-Making: Fundamental Political Processes ........... 63

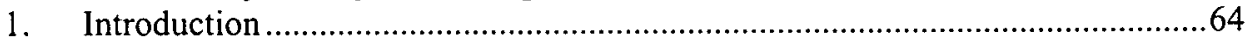

2. The Legislative Process ..................................................................................64

2.1 Community legislative procedures: From consultation to co-decision .............65

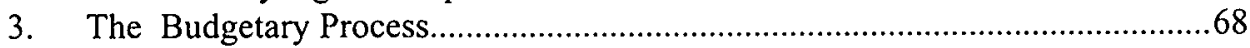

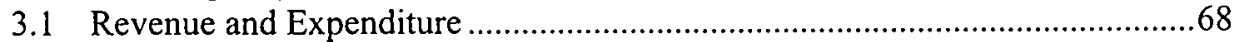

3.2 The adoption of the annual budget ………….............................................

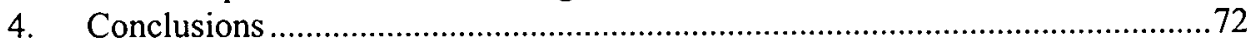

4 Theories on Community Policy-Making .................................................... 75

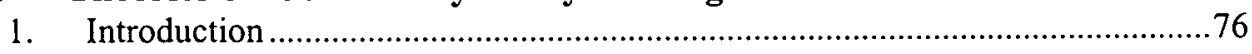

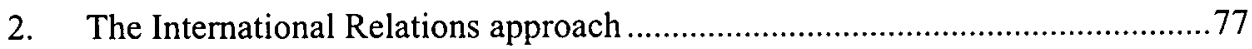

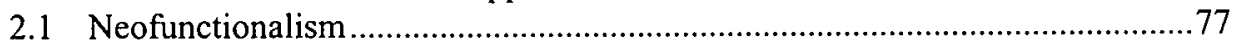




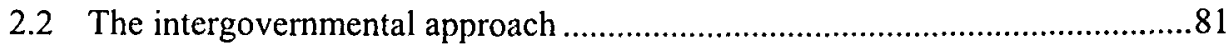

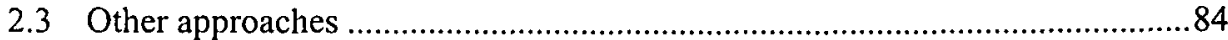

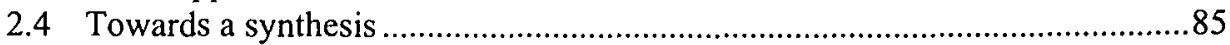

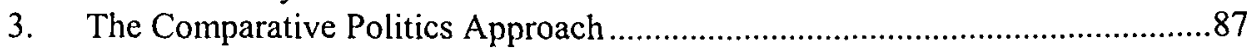

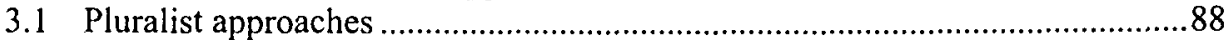

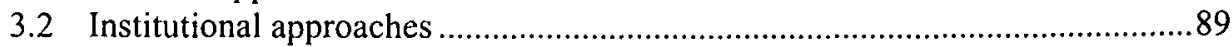

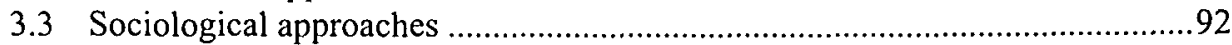

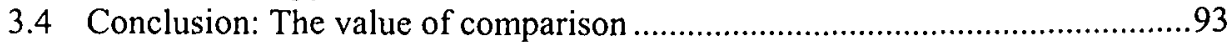

\section{European Community Harmonisation \& Spillovers into Health}

Regulation ........................................................................................99

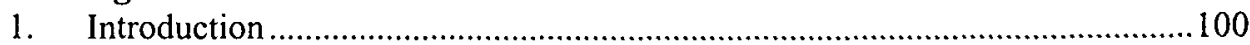

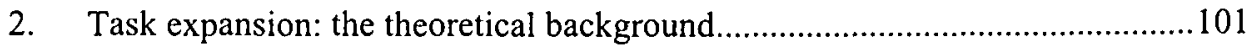

3. Legislative data: preliminary presentation and analysis................................104

4. Free movement of goods and EC policy in the field of medicines..................110

5. Free movement of goods, and environmental, consumer and public health

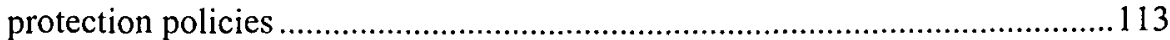

6. Free movement of goods, working environment, and occupational health

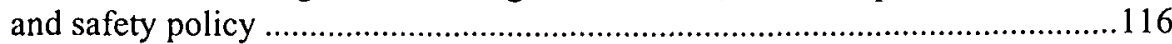

7. Free movement of persons, the right of establishment, and education of

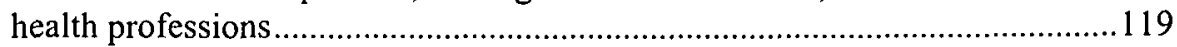

8. Free movement of persons, workers and social security ................................120

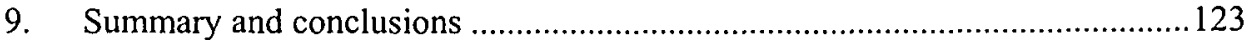

6 Social Security \& Health (care) Systems: from Harmonisation \& Convergence to the Reality of Monetary Union ..................................... 129

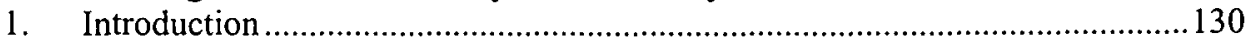

2.1 The Social Provisions in the EC Treaties ..................................................132

2.2 Harmonisation of the social security systems: Elements of a heated

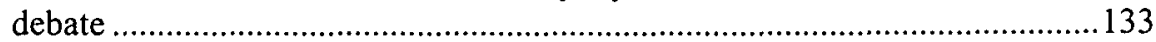

2.3 From the Social Charter to the Convergence of Social Protection

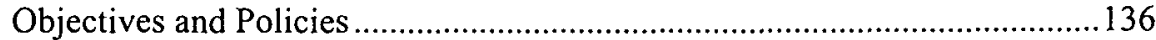

2.4 The Social Protocol and the Social Policy Agreement..................................140

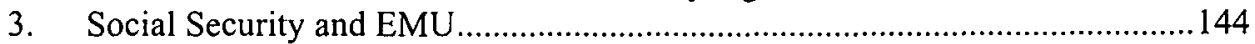

3.1 Social and Political Implications of EMU for Social Security ........................144

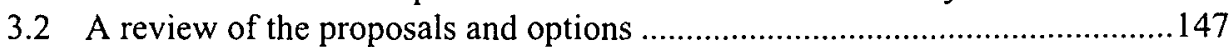

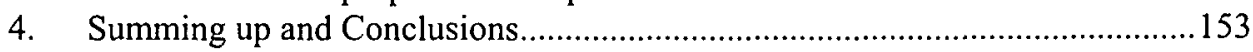

7 EC Public Health Activities \& Programmes: Prevention, Health Information, Education \& Research .................................................... 161

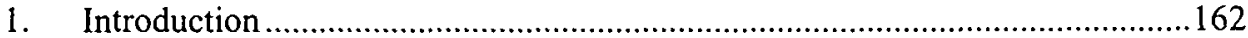

2. Public Health Activities: Prevention, health information and education ..........163

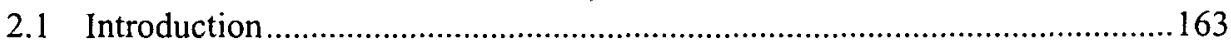

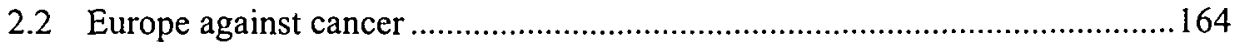

2.3 Europe against AIDS ................................................................................170

3. Medical and Health Research as a part of Community's Research Policy .......175 
3.1 An introduction to the EC research and development (R\&D) policy: The Framework Programmes

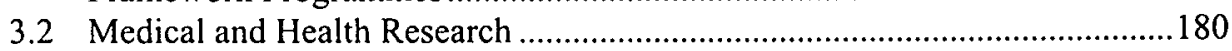

3.3 The co-ordination of projects in the field of Health Services Research (HSR)

4. Public Health Policy after Maastricht and Amsterdam ...................................188

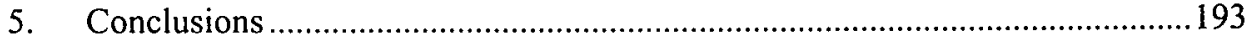

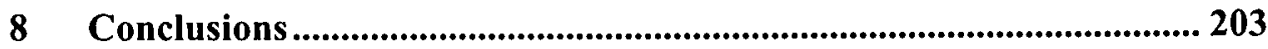

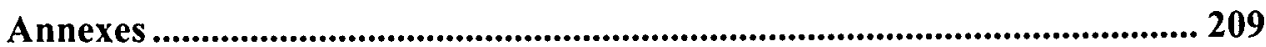

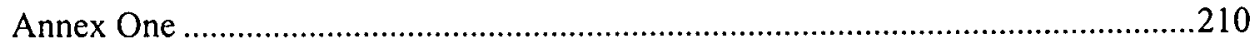

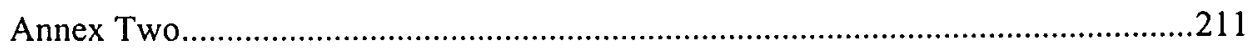

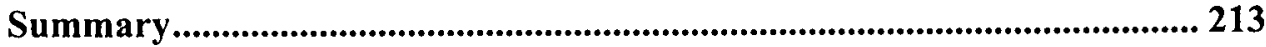

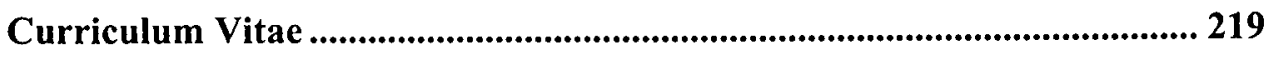

Publications ........................................................................................................... 219 


\section{1}

General

\section{Introduction}




\section{Introduction}

It is widely recognised that for most of its existence the European Community had only limited competence in public health. ${ }^{.}$This lasted until the nineties when public health was explicitly defined within the Community's competence. Article 129 of the Treaty of the European Union (1993), often named as the Maastricht Treaty, identified public health as a new general policy field for the Community and also formulated an objective to be achieved, namely "a high level of human health protection". More concretely, it was stated that,

"community action shall be directed towards the prevention of diseases, in particular the major health scourges, including drug dependence, by promoting research into their causes and their transmission, as well as health information and education".

Article 129 of the Maastricht Treaty not only formally broadened the possibilities of the Community to develop a health policy. It also went one important step further by stating that it was the responsibility of the Community to develop, what may be called, a healthy Community policy. Such a policy was implied by the statement that,

"health protection requirements shall form a constituent part of the Community's other policies".

The Community's competence in public health was reconfirmed and somewhat extended in the Treaty of Amsterdam of 1997. Due to various food related issues, in particular the BSE crisis (mad cow disease), and other typical public health concerns such as long-standing environmental problems, the objectives of Community action were redefined. A new Article, 152, states that,

" a high level of human health protection shall be ensured in the definition of all Community policies and activities".

It is furthermore stated, that,

"Community action (.....) shall be directed towards improving public health, preventing human illness and diseases, and obviating sources of danger to human health".

Such action,

"shall cover the fight against the major health scourges, by promoting research into their causes, their transmission and their prevention, as well as health information and education".

When these formulations are compared with those in article 129 of the Maastricht Treaty, the conclusion may be drawn that, at least prima facie, the declared objectives of Community healthy policy in the Amsterdam Treaty look more demanding than they were in the Maastricht Treaty, and that the responsibility of the Community for public health has increased. ${ }^{2}$ This conclusion is reinforced by the fact that the policy 
tools in the hands of the Community were somewhat extended in the Amsterdam Treaty, a point to which we will return at the end of this section.

The recent formulation of public health as the Community's competence may suggest that Community intervention in health issues is completely new. This, however, would be a wrong conclusion. In fact, the Community has always dealt with health issues since its creation in the fifties. Health and safety at work were mentioned, for instance, in the European Coal and Steal Treaty (1951), in the Euratom Treaty (1956), and in the Treaty of European Economic Community 1957, (also named the Treaty of Rome) which extended the provisions on health and safety at work to all industries. A fundamental underlying idea of the EEC Treaty was the recognition that the realisation of the common market, in particular the free movement of goods and persons, should not be achieved at the expense of an adequate protection of human and public health. Some articles in the Treaty allowed the member states to make exceptions to the rules designed to achieve the free movement of goods and persons as far as these exceptions were held necessary for the protection of human and public health. ${ }^{3}$ Health was also mentioned in the Single European Act (1987), with article 100a stating that the Commission, in its proposals to issue directives for the establishment of the common market,

\section{"concerning health, safety, environmental protection and consumer protection, will take as a base a high level of protection".}

The Community's involvement in health prior to Maastricht and Amsterdam was also illustrated by the launching of two typical public health programmes, namely "Europe against Cancer" in 1988 and "Europe against AIDS" in 1991.

In the light of all this early Community action on health, it may be argued that, the new treaty powers on public health should be understood as a codification of existing policies and practices. In our view, however, this is only part of the truth. The new treaty provisions have broadened the possibilities for placing public health concerns on the general policy agenda of the Community. Thus, they provide opportunities for modification as well as codification.

Generally speaking, it can be said that the Community's involvement in health followed different interrelated tracks. The first track is directly linked to the primary goal of the Community, namely the creation of a single market by the removal of all barriers to a free movement of goods, services, labour and capital. Regulations on the internal market worked as a source of legislation in the field of health. They covered, for example, pharmaceutical and medical devices, and the health rights of workers moving within the Community. Regulations also covered areas where the Community has acquired legislative powers such as consumer policy and environmental policy. For example, one of the objectives of consumer policy is to protect the health and safety of consumers. Many of the activities in this area concern product and food safety. Protecting human health has also been one of the objectives of the Community's environmental policy through, for example, the improvement of air and water quality.

Under the umbrella of social policy the Community deals with the issue of social security or social protection including the right of access to health care and benefits. 
This right was already laid down in the famous Regulations $1408 / 71$ and $574 / 72$ of the Treaty of Rome on cross-border care. The right of access to health care and benefits also formed part of the Community Charter of the Fundamental Social Rights of Workers which was adopted in 1989 by all Member States with the exception of the United Kingdom. According to this Charter,

"every worker of the European Community shall have a right to adequate social protection and shall (.......) enjoy an adequate level of social security benefits".

The protection of health and safety at work is another noticeable part of social policy where the Community has undertaken legislative action.

The growing interest of the Community in stimulating scientific research and development implied a further extension of the Community's involvement in health. It is fair to say that the "health and medical industry" in Europe have greatly benefited from the Community's research policy and programmes. Its co-ordination and finance of medical and health research projects started in 1978. It led to the initiation of typical public health programmes and culminated in explicit definitions of public health as being within the Community's competence in the Maastricht and Amsterdam Treaties.

In this study we aim at a more in-depth analysis of the Community's involvement in health. How and why did the Community move into health? In addressing this question we shall also discuss the institutional and policy-making context of the Community, which is essential since the increasing involvement of the Community in public health cannot be properly understood without taking its institutional context into account.

A study on the Community involvement in health can be conducted from different perspectives. One perspective is to ask what the Community has done and achieved so far in the field of health; how its policies were developed and what factors influenced the policy-making process. But there is also a different perspective, which focuses upon the limits to Community policy-making in health. In this perspective, the leading question is not what the Community has done, but what the Community has not done, cannot do and why? These are important issues, which have drawn the attention of Community policy analysts. Although there are certainly differences in how the Community's opportunities for policy-making in the field of health are appreciated, consensus exists on the fact that these opportunities should not be overestimated and are in fact subject to serious limitations. These limitations are clearly highlighted, for instance, in the Maastricht Treaty, when one takes a closer look at the policy instruments available to the Community to achieve its goals in public health. Article 129 of the Maastricht Treaty speaks of adopting,

\section{"incentive measures, excluding any harmonisation of the laws and regulations of the Member States".}

In other words, regulations and directives are ruled out as policy instruments in the field of public health. Furthermore, the Community is explicitly denied a formal competence to harmonise national health care systems. Recommendations, the weakest form of Community intervention, require a qualified majority in the Council of Minis- 
ters. Finally, it is explicitly stated that the promotion and protection of public health is certainly not the exclusive competence of the Community. According to the principle of subsidiarity, the main powers remain in the hands of the member states. The Community is only entitled to act, where the objectives of public health cannot be effectively achieved through national action and where Community action would result in some kind of additional 'European value'. In the Amsterdam Treaty the Community's competencies were somewhat extended, but still remained limited. The public health powers of the Community were imbued with the notion of subsidiarity, and an additional paragraph underscores that Community action in public health must fully respect the responsibilities of the Member States with regard to the organisation and delivery of health services and medical care. Health care systems remain the exclusive competence of national governments, which are reluctant to give up their powers.

In this study, then, we will not only discuss the development of the Community involvement in health. It is also our intention to analyse and assess the limitations to Community policy-making on public health. The sources of these limitations can be partly found in the formal competencies of the Community and they are also related to political and economic interests as well as cultural differences.

\section{Community health policy and healthy Community policy}

Before further elaborating our research questions, we shall first briefly discuss some concepts on health. Let us begin by pointing out the basic difference between medicine and public health. While medicine generally focuses on the health of the individual, public health emphasises the health of populations. Individual health can be considered the concern of medical and other health services. By contrast, public health may be defined as "...(ensuring) the conditions in which people can be healthy.", Thus, public health has a distinct health-promoting goal. It underscores the prevention of disease, disability and premature death.

From a public health perspective, the availability of medical and other health care facilities constitutes one of the basic conditions for health. But it is not synonymous with health, because the health status among populations cannot be attributed only to health care. In other words, health care is a necessary but not sufficient condition for health. Health is influenced by many other determinants, such as life style, nutrition, safety, and education, housing, cultural, environmental, working and other living conditions.

A health policy ${ }^{5}$ (or public health policy) may be defined as a policy which, through the use of various policy instruments, attempts to promote the health of the population. These policy instruments may take the form of regulations, incentives or disincentives, communication or information. Since the health of the population is subject to so many determinants, any health policy must encompass a broad range of policies and programmes of which the nation's health care policy is only one part. This broad range not only presents a challenge to the policy-makers, but is also a source of weakness. The boundaries of health policy are fuzzy and policy-makers who want to promote 
public health must engage in inter-sectoral policy-making. Take for instance the issue of the quality of food. The quality of food can be considered an important determinant of health and, therefore, should be addressed in a health policy. But food is also linked to other issues of employment, agriculture, industry, trade, consumer preferences. For that reason health policy-makers must bargain with policy-makers in other policy sectors. The underlying belief of a health policy is that health problems can only be effectively addressed if contributions are made from different policy sectors.

A public health policy can be distinguished from a healthy public policy. Whereas a health policy starts from a health perspective, a healthy public policy starts from another sectoral perspective, for instance an agriculture or an international trade perspective. The essence of a healthy public policy is that each policy sector should judge its policies and programmes not only, for instance, on economic aspects, but also on public health consequences. ${ }^{6}$ Needless to say that a health policy and a healthy public policy are closely intertwined.

The distinction between a Community health policy and healthy Community policy is also underlying Article 129 of the Maastricht Treaty. The Community health policy aims at "a high level of human protection". At the same time, it is said that "health protection requirements shall form a constituent part of the Community's other policies". This is the essence of a healthy Community policy.

\section{Aim and scope of the analysis}

This study aims at a description and analysis of the gradual expansion of Community involvement in public health and the perspectives that underlie it. In performing this task, we shall see the Community in the terminology of Sbragia as a "partial polity." In this view, Community health policy is conceptualised as the output of Community policy-making. Thus, our level of analysis will be the Community level, not the national level. This analytical choice has important implications. The (health) policies of the Member States are only of interest for us to the extent that they influence Community policy-making on health. More importantly, however, we shall not present an investigation of the impact of Community health policy on the health policies of the Member States. Of course, this is an interesting topic of research, but it remains beyond the aim and scope of our study. A full analysis of the implementation of the Community regulations, directives and decisions and their impact upon the domestic health policy would require a different study plan than presented here. It is wellknown, however, that the implementation of many Community policies has been far from self-evident and is influenced by many domestic variables such as national interests, political preferences, the role of interest groups, and the power balance in the policy arena ${ }^{8}$.

We shall study the Community policy-making on health within the general institutional context of the Community. Our analysis is based upon the assumption that the institutional structure and the rules for policy-making are of importance in the health field . Community policy-making on health does not take place in an institutional vacuum, but is strongly influenced by the activities of the major 
Community policy players: the way they define their responsibility for policy-making; and the major decision-making procedures as set out in the Treaty of Rome, the Single European Act, the Treaty of Maastricht and, finally, the Treaty of Amsterdam.

Community policy-making on health is also affected by general policy contexts. In section 1 we saw how Community involvement in health followed different, but closely intertwined tracks, and was closely linked to the development of the Single European Market, social policy and research. Thus, the study of the expansion of the Community's health agenda should also be placed within the context of these broader policy developments in the Community.

\section{Outline of the study}

Our analysis starts with an analysis of the Community institutions. Chapter 2 examines the chief characteristics of the three main institutions involved in policy-making: the Member States acting within the Council of Ministers and the European Council, the European Commission, and the European Parliament. In general terms, it may be said that the formal institutions established by the Treaty of Rome in 1957 and the rules governing the relationships between those institutions, indicated a pattern of policymaking in which the Commission would propose, the Parliament would advise, and the Council would decide. The general balance between the institutions has always remained more or less the same. Yet, changes introduced by the Single European Act and the Maastricht Treaty altered the policy-making role of these institutions. The implications of those changes for health policy-making will be therefore in the focus of analysis. Chapter 2 also contains a brief description of the European Court of Justice. Although the ECJ is not a policy-making institution itself, it can be stated that its decisions often have important implications for policy-making in the Member States. In a sense therefore, the ECJ can be seen as a quasi policy-making institution.

The policy instruments provided in the field of health consist of a capacity to frame common legislation and to develop spending programmes. A preliminary step to a more detailed analysis of existing and ongoing activities, therefore, is to outline the concrete institutional rules governing the making of Community law and budget. Chapter 3 focuses on the decision rules of two policy-making processes: the legislative process and the budgetary process. As we shall see, the power balance between the institutions is different in these two processes. For example, the Parliament's room for manoeuvre has traditionally been greater in the budgetary than in the legislative process. However, as a result of recent changes, the Parliament cannot only use its budgetary powers and affect the funds allocated to health programmes, but can also make use of its new co-decision powers with the Council in the legislative process and affect the development and the content of health policy programmes.

Our analysis of the Community's institutions is completed in chapter 4, which addresses the question, what kind of political organisation is the Community? Two theoretical perspectives to the study of Community politics are differentiated: International Relations and Comparative Politics. The distinction refers more to the discourse than the methods used by various scholars. The academic discourse of 
international relations has dominated the debate since the inception of the Community in the 1950s. Scholars have concentrated largely on the nature of activity among sovereign nation-states and relied on different assumptions to explain the process of regional integration in the Western Europe. There are two major theoretical perspectives here. In the first perspective the Community is conceptualised as a supranational organisation. A central role is envisaged for supranational institutions, in particular the Commission, in the Community policy-making process . It is the complex interaction between a multitude of agents such as interest groups, national and European political elites, which determines integration in the Community. This first perspective is usually referred to as the neo-functionalist perspective. The early neofunctionalist contribution to the study of the Community represents an important attempt to understand the significance of the Community treaties and the commitments that followed from these. Neo-functionalism represents the first theoretical effort to explain and predict Community task expansion - that is, the movement from the removal of barriers to trade to the pro-active co-ordination of common policies in order to fulfil economic and welfare objectives. The alternative approach, often labelled as the realist (intergovernmetalist) perspective, sees the Community more as an international than a supranational organisation. In this perspective, regional integration proceeds insofar as it is in the interest of the Member States. As a result, the progress towards integration has been slow, difficult and far from continuous. Policy-making is dominated by the Member States, which are primarily interested in the promotion and defence of their national interests. Government leaders are motivated by the desire to maintain and enhance their power position in the international arena. Realist interpretations of the integration process focus attention on the central role of the governments in the Community policy-making. They also pay attention to the significance of the similarities and differences in the national circumstances, historical experiences and practices of the units that are engaged to integrate. According to J. Bailey,

"the power of cultural and historical experience to resist new demands coming from 'outside' and the attempts by international agencies to overcome these resistance's is the history of the European Community"

The making of Community policy has considerably increased in recent years. The political controversy regarding both the governance and the policy capacity of the Community has considerably increased as well. Now, the political and scholarly debate is not so much about its uniqueness among international organisations but about classical political issues such as participation and representation, authority and legitimacy, power and accountability, conflict and compromise, effectiveness and justice. We shall see that the Comparative Politics approach opens the way to conceptualise the Community as a (partial) polity. It applies concepts and principles deriving from the study of the nation state to the analysis of Community politics and policy-making. The underlying idea is that the use of theoretical concepts, which have their roots deep inside the domestic political systems of the member states, may yield interesting new insights in the structure of Community integration and policy-making. 
The remaining four chapters are all concerned with a more detailed presentation of health policy developments. The expansion of the Community's health agenda is examined in relation to three areas of Community action, namely single market, social policy and research. The selection of these activities should not imply that they form a coherent policy framework. These activities represent cases with their own trajectories and established precedents within the history of the Community. The analysis of the expansion of Community's health agenda will focus on policy outputs as measured in legislation (directives, regulations, etc.) and budgetary expenditures.

Chapter 5 describes and explains the expansion of the Community policy agenda to health legislation. The existence, timing, and content of Community regulatory action regarding health are explained primarily in terms of functional spillover from the single market. We shall see how the single market programme has led to significant progress in Community harmonisation of national legal measures and in the introduction of legal measures concerned with health and health care. This process has been accelerated in recent years. Community legal measures examined are concerned with medicines, environment, consumer protection, worker safety, education of health professions and the rights to social security of the migrant workers and migrant selfemployed. The purpose of Community regulation is primarily concerned with problems of market failure - especially negative externalities and information failures. It represents an important area of Community involvement in health, safety, and more generally quality of life.

Chapter 6 focuses on certain facets of health and Community social regulation. Following some observations about the main features of social and health protection systems in the Community countries, an introduction to the Community's 'social area' and to its broad orientations appears appropriate. We focus on the provisions pertinent to social policy in the treaties and conclusions are drawn as to their significance for Community involvement in social and health protection systems. We discuss also the recent developments concerning the Community Charter of the Fundamental Social Rights of Workers as well as the Social Protocol or the Social Policy Agreement. Finally, attention is drawn to the impact of the monetary union on social protection systems and we examine existing proposals and policy options for the Community to play a more active role in income redistribution and indeed in social protection programmes. As we shall see, the harmonisation of social and health protection systems has been the focus of debate since the establishment of the Community in the 1950s. Harmonisation has never been implemented. In recent years, however, the term "convergence" comes to the fore. Discussions have been axed as to whether social protection standards should be established at the Community level and, if so, in which way. Instead, the discussions have shifted to the impact of monetary union and convergence criteria (inflation, budget deficits, public debt) on social protection programmes.

Chapter 7 concentrates first on policy responses - prevention, health information and education - to major public health problems, such as cancer and AIDS, all of them initiated in the middle 1980s. We discuss the policy-making processes from which these programmes resulted as well as their priorities and content. Moreover, chapter 7 reviews policy developments in the field of research. It addresses first the broad 
orientations of the Community's R\&D policy. Following these observations, the analysis is concerned with the evolution and priorities of biomedical and health research, and the co-ordination of activities in the field of health services research in particular. The policy salience of research has increased considerably during the last decade and especially after the introduction of the Single European Act in 1987. Economic preoccupations and technological objectives dominated the broad orientations of the Community R\&D policy. However, biomedical and health research activities increased in the context of this policy. Finally, recent policy developments after the Maastricht Treaty are discussed, as is the revision of public health provisions initiated by article 129 of the Treaty of Amsterdam. Their significance for the development of a planned Community framework for public health action is examined.

Finally, chapter 8 picks up some of the observations and conclusions of the preceding chapters and adds to them an analysis of the limitations to Community policy-making on health. This analysis not only leads us back to the Treaties of the Community, but also directs our attention to economic, political, bureaucratic, cultural and other obstacles.

In the next section we shall present a brief overview of the development of the Community, its political and institutional framework, and its main policy orientations.

\section{Policy and Institutional Framework of the Community.}

The three founding treaties of the Community entered into force during the 1950s: the European Coal and Steel Community (ECSC, signed in Paris in 1951); the European Economic Community (EEC, signed in Rome in 1957); and the European Atomic Energy Community or the Euratom treaty (EAEC, signed in Rome in 1957). These all constitute the fundamental legal and policy framework on which the Community is based.

Six member states originated the first agreements resulting to these treaties: Belgium, France, Germany, Italy, Luxembourg and the Netherlands. With four successive enlargements the size has grown: from six to nine (the United Kingdom, Ireland and Denmark, 1973), to ten (Greece, 1981), to twelve (Spain and Portugal, 1986), and most recently to fifteen (Austria, Sweden and Finland, 1995). New members had to adopt to the existing institutional structure and priorities of the EC. Successive enlargements affected the policy framework of the EC as the new members brought with them their own concerns and requirements.

Our discussion about Community involvement in health policy is based on the treaty establishing the European Economic Community (EEC), amended by the Single European Act in 1987, and by the treaty on the European Union in 1993 (the Treaty of Maastricht). Recent amendments by the Amsterdam Treaty, particularly in relation to the public health article will also be discussed. Of the three founding treaties, the EEC treaty is by far the most important. The objectives of the EEC, as laid down in article 2 of the EEC treaty in 1957, were primarily economic. They were defined as, 
"an harmonious development of economic activities, a continuous and balanced expansion, an increase in stability, an accelerated raising of the standard of living and closer relations between the States belonging to it".

To this end, "establishing a Common Market" and "approximating economic policies", were to be the means for reaching the desired ends ${ }^{10}$. At the heart of its policy framework, therefore, have been the so-called common market policies, such as policies designed to encourage the free movement of goods, persons, services and capital; policies to foster market competition and to eliminate prohibitions on restrictive practices, dominant trading positions, and state aids; policies to establish the customs union or the common external tariff put in place by 1968; and, finally, the common external trading policy. Further fields of EEC policy listed included a common policy in agriculture, transport policy, economic policy, social policy and the European Investment Bank.

Extensive and intense negotiations between governments concerned changes to the EEC Treaty that have resulted in important policy developments in recent years. Firstly, in 1985 a decision was made to complete the internal market by removing all physical, technical and fiscal barriers within the Community by 31 December 1992. In 1987, the first major revision of the Treaty establishing the EEC, the Single European Act (SEA), came into force and altered the operations of the Community to facilitate its legislative procedures. New policies were also placed upon the Community agenda such as economic and social cohesion, research and technological development and environment. The EEC treaty was amended by the Treaty on European Union, which came into force in 1993. The Maastricht Treaty establishes the European Union and has a particularly complex structure. It is based on three pillars. The EEC is now to be called the European Community and constitutes the first pillar. The Common Foreign and Security Policy and the Co-operation in the Fields of Justice and Home Affairs were to constitute the second and the third pillars respectively. (See also table 1 on the contents of the Treaty on European Union). These policy developments are now a major discourse object of popular concern. They are the focus of enormous media coverage, of constitutional discussions, of political warnings, of ideological disputes, of fears, and of anxiety.

The objectives of the European Community were amended and redefined in the Treaty of the European Union as,

"an harmonious and balanced development of economic activities, sustainable and non - inflationary growth respecting the environment, a high degree of convergence of economic performance, a high level of employment and of social protection, the raising of the standard of living and quality of life, and economic and social cohesion and solidarity among Member States".

"Establishing a common market, and an economic and monetary union, and by implementing the common policies and activities". " 
are considered the principal tools for reaching the objectives of the Community. Whilst existing Community policies are reinforced, new competencies include, among others, consumer protection and public health.

The last treaty comprises, all the forms of co-operation that have been built up on foreign and security policy, justice and home affairs. These remain essentially fields of intergovernmental co-operation. The Community policy framework has become so extensive that it now incorporates initiatives and developments in virtually every sphere of public policy. In many cases responsibilities have been clearly transferred away from national governments to the Community. This is particularly true for economic management. Examples include the operation of a customs union, the negotiation of external trade agreements, the operation of the single market, competition policy and last but not least monetary policy. It is also true for agricultural policy, including the management of the agricultural market for those products on which prices have been agreed. Here, national authorities can be seen as partners in the policy process, but also act as agents of the Community.

The single market programme led to a considerable increase in Community competencies with regards to so-called legislative policies such as environment and consumer protection. The Community is now heavily involved in legislation with regards to health, safety, and more generally quality of life. Community involvement has also increased in regional policy, which is concerned with the countries of the south and Ireland. In most other policy sectors, Community funding allows financial contribution to projects in the member states, but in no sense replaces or overrides national policies. Examples include social policy, environment, consumer protection, research and technological development,

\section{Table 1: The Three Pillars of the European Union}

\section{PILLAR ONE}

The new European Community (EC) Treaty: Contents

(Provisions on the European Economic Community)

I Principles

II Citizenship of the Union*

III Community Policies**

1. Free movement of goods (the customs union, elimination of quantitative restrictions between member states)

2. Agriculture

3. Free Movement of Persons, Services and Capital

4. Transport

5. Common Rules (competition rules, tax provisions and approximation of laws)

6. Economic and Monetary Policy (this heading refers to the majority of the new provisions on European Monetary Union) 


\section{Common Commercial Policy}

8. Social Policy, Education, Vocational Training and Youth (c.f. there is also an agreement on social policy between the eleven which has been inserted to the treaty as a protocol)

9. Culture

10. Public Health

11. Consumer Protection

12. Trans - European Networks

13. Industry

14. Economic and Social Cohesion

15. Research and Technological development

16. Environment

17. Development Co-operation

IV Association of the Overseas Countries and Territories

V Institutions of the Community*** (The European Parliament, the Council, the Commission, the Court of Justice, the Court of Auditors, Provisions Common to several institutions, The Economic and Social Committee, The Committee of the Regions, European Investment Bank, Financial Provisions)

VI Final Provisions

\section{PILLAR TWO}

Provisions on a Common Foreign and Security Policy (including the eventual framing of a common defence policy) - Intergovernmental construct.

\section{PILLAR THREE}

Provisions on Co-operation in the Fields of Justice and Home Affairs (asylum policy, rules governing the crossing of external borders of the member states, immigration policy, drug addiction and fraud, judicial co-operation, customs cooperation and police co-operation) -Intergovernmental construct.

* Added by the Treaty on European Union

** New Titles: Culture, Public Health, Consumer Protection, Trans-European Networks, Industry

*** The Committee of the Regions is a new institution

education and public health. The pattern of policy-making varies considerably from sector to sector depending on the extent of the Community involvement, the type of instruments used (legal or financial) and the continuing importance of national policies. 
Finally, the subsidiarity principle, which was already implicit in previous Treaties, is placed in the preamble of the Maastricht Treaty. It is stated that,

"in areas which do not fall within its exclusive competence, the Community shall take action, in accordance with the principle of subsidiarity, only if and in so far as the objectives of the proposed action cannot be sufficiently achieved by the Member States and can therefore, by reason of the scale or effects of the proposed action, be better achieved by the Community. Any action by the Community shall not go beyond what is necessary to achieve the objectives of this treaty $^{\prime \prime 2}$.

The principle of subsidiarity may be used in future as a criterion to justify Community action in areas that do not fall under its exclusive competence. Much depends here on the interpretation, which may range from broad to narrow. Public health is an area where the Community interpretation of the subsidiarity principle may affect the scope of its action.

Jacques Delors once summarised this principle by saying,

"that what can be done at the company level should not be done elsewhere, that what can be done at the regional level should not be done at the national level, and, finally, that what can be done in the member states should not be done in Brussels."

Subsidiarity is originally deeply rooted in the social theory of the Catholic Church. From the viewpoints of philosophy and political science subsidiarity is a guiding principle in the evolution of the constitutional theory and governmental practices of the federal states. In essence, it is concerned with both the repartition of tasks between central government and its constituent units, and the regulation of this repartition. Subsidiarity has become an integral part of Community discussions about economic and political integration and the distribution of powers between the national governments and the Community. In the EEC Treaty, article 235 gave the Community the competence to act in the absence of specific authorisation in all those cases where Community action is required in order to complete the common market. In 1984, the European Parliament included the subsidiarity principle in its Draft Treaty for European Union, known as the Spinelli draft. Subsidiarity was mentioned explicitly in the Single European Act in relation to Community action in environmental affairs (art. 130r). The principle of subsidiarity was further elaborated in the Delors' Report on Economic and Monetary Union. It became a key element in the work of the Intergovernmental Conferences on Economic, Monetary and Political Union and appeared finally in the Maastricht Treaty. Its explicit reference here shows the increasing interaction between national and Community competencies ${ }^{14}$.

\section{Sources}

Our data come from different sources. First, theoretical literature provides information about the main features of the political system, including the decision-making 
environment and the institutional design process. The legislative and the budgetary process of the European Community are both well documented and reported. Community documentation is used for all levels of analysis and particularly for topics mentioned in relation to the three areas explored by this study.

The Community issues a vast amount of material, from brief information leaflets to weighty reports. A detailed review of Community publications is not possible here. What follows is merely an outline guide to major publications. The Treaties establishing the European Communities should naturally be consulted by those who wish to understand the nature and functioning of the Community. The Office has published them in several editions, among others, for Official Publications of the EC. The Official Journal of the European Communities (OJ) is issued on most weekdays and provides the authoritative record of decisions and activities of various kinds.

The most detailed analysis and information about Community policies are usually to be found in documentation produced by the Commission. Useful material stemming from other institutions regularly includes Reports, Dossiers, and Research Documents of the European Parliament.

Information comes also from interviews. About fifty people were asked about facts concerning topics and their opinions about events. The interviews were open-ended in nature and are considered an important source of Community documentation. Amongst the interviewees were: officials working at the European Commission (Directorate General V, XII, XIII); members of the committees of the European Parliament (Committee for the Environment, Consumer Protection and Public Health); Research Committee; and the European Parliamentary Office of Technology Assessment (STOA); national representatives; non governmental organisations such as the (European Public Health Alliance - (EPHA); the European Social Observatory (OST); and trade unions (European Trade Union Confederation - ETUC).

\section{Chapter One References}

1. M. McKee, The influence of Europe on national health policy, in: L.J. Gunning-Schepers, G.J. Kronjee, R.A. Spasoff, Fundamental questions about the future of public health, Netherlands Scientific Council for Government Policy, The Hague, 1996, pp. 217-242.

2. A.P. van der Mei, L. Waddington, Public Health and the Treaty of Amsterdam, in: European Journal of Health Law, vol. 5, 1998, pp. 129-154.

3. ibid, p. 132.

4. Institute of Medicine, Future of Public Health. Washington DC, National Academy Press, 1988. 
5. See for instance E. de Leeuw, Health policy. An exploratory inquiry into the development of policy for the new public health in the Netherlands, Maastricht, 1989.

6. M. Goumans, Innovations in a fuzzy domain. Healthy Cities and (Health) policy development in the Netherlands and the United Kingdom, Maastricht, 1998.

7. A. Sbragia (ed), Europolitics. Institutions and policymaking in the "New" European Community, Washington, The Brookings Institution, 1992.

8. H. Siedentopf and J. Ziller (eds), Making European Policies Work: The Implementation of Community Legislation in the Member States, Vol. I, Comparative Syntheses, European Institute of Public Administration, London, Sage Publications, 1988; J. Richardson, Eroding EU policies, implementation gaps, cheating and re-steering in $\mathrm{J}$. Richardson (ed), European Union, Power and Policy-Making, London and New York, Routledge, 1996; S. Mazey and J. Richardson, The logic of organisation, Interest Groups, in J. Richardson (ed), European Union, Power and Policy-Making, London and New York, Routledge, 1996.

9. J. Bailey, Social Europe: unity and diversity - an introduction, in J. Bailey (ed), Social Europe, London and New York, Longman, 1992, p 7.

10. Treaties establishing the European Communities, Luxembourg: Office for Official Publications of the EC, 1987.

11. Treaty on European Union, Luxembourg: Office for Official Publications of the EC, 1992.

12. ibid

13. Quoted from Chr. Altenstetter, Health Policy Regimes and the Single European Market, in: Journal of Health Politics, Policy, and Law, vol. 17, Winter 1992, pp 813-846, pp. 823-824,

14. Proceedings of the Jacques Delors Colloquium, Subsidiarity: The Challenge of Change, European Institute of Public Administration, Maastricht 1991. 


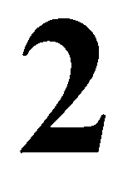

\section{The Institutions of the Community}




\title{
1. Introduction
}

\begin{abstract}
"Policies, once adopted, are embedded into institutions. They are associated with rules, expectations, and commitments. By affecting attention and aspirations, they affect the future search behaviour of political participants"
\end{abstract}

James G. March and Johan P. Olsen'

As a preliminary step to a more detailed description and analysis of Community health activities, this chapter addresses the main attributes of the Community's policy-making institutions. A great number of official and unofficial actors are involved in the Community policy-making process. The role of official institutions in policy-making, that is the institutions that are based upon the Community treaties, should be considered crucial. There are four main institutions: the Council of Ministers and the European Council, the Commission, the European Parliament, and the European Court of Justice. We will not attempt to present any full-scale description of the nature of these institutions. That task has been done thoroughly elsewhere. ${ }^{2}$ We restrict ourselves to pointing out several salient features of these institutions, paying attention to how they are involved in Community policy-making on health.

\section{The decision-making body: Council of Ministers and the European Council}

The Council, comprising representatives of the governments of the Member States, is generally portrayed as the preponderant authority in making Community decisions. The Treaties do not provide an equivalent to the distinction between the legislature and the executive as do national constitutions. The Council, which is composed of the representatives of the governments of the Member States, is the legislature of the Community, not the European Parliament. As Deirdre Curtin pointed out, the discussion about democratic accountability has focused over the years not on substituting the European Parliament for the Council in the legislative role but on the development of a system enabling the Parliament to participate in law making decisions $^{3}$. The Council does not operate as a more or less independent institution within the Community's institutional framework. Community law requires that every act of the Council (regulations, directives and decisions) be adopted on the basis of proposals initiated by the Commission. Moreover, the Council must take account of the advice from the European Parliament.

According to Guy Peters, the Council may be depicted as the institution most similar to one found in a conventional international organisation. It represents the nationstates that constitute the Community. Its interactions depend more on diplomacy and bargaining among national representatives than upon collegial interactions. ${ }^{4}$ Nowadays, often fifteen competing opinions must be considered before arriving to an acceptable compromise on a Commission proposal. 
Over time, the Council has greatly enhanced its policy initiation role and has also ensured that national governments are centrally placed to influence most aspects of Community politics. It did this by encroaching on the Commission's role in policy initiation and by becoming a forum exercising important responsibilities of mediation and consensus building. ${ }^{5}$

The presidency of the Council of Ministers rotates among the member governments every six months. At the end of each presidency there is a meeting of the European Council. This is the institutionalised forum for the meetings of Heads of State and Government, the foreign ministers of each of the fifteen member countries, the president of the Commission and one other commissioner. The summits of the European Council were regularised in 1974, but remained outside the institutional framework of the Community treaties until the Single European Act (1987). They are distinct organs of the Community, separate from and superior to the Council of Ministers. The European Council neither acts subject to a proposal from the Commission nor is subject to any parliamentary control. However, to the extent that the Council adopts acts pursuant to the European Council guidelines, they are subject to the decision making rules governing the functioning of the Community and also to the judicial control exercised by the European Court of Justice. It is at the level of this intergovernmental organ that the most visible decisions on bringing Europe towards greater economic and political integration are announced. In addition, the European Councils have increasingly launched their own policy initiatives when a powerful coalition of some states (always including France and Germany) supported them ${ }^{6}$. They have also increasingly dealt with specific sectoral policy issues. It was for instance at the level of the European Council that the initiative to set up a first public health action program to fight cancer was undertaken.

\subsection{Composition and Organisation}

As its name implies, the Council of Ministers consists of ministers appointed (one each) by member governments. Members of the Council of Ministers are elected from the member countries and rotate according to the subject being discussed. The minister on foreign affairs is regarded as the country's main representative in the Council. The ministers of agriculture, transport, economic and financial affairs, industry, social affairs, environment, science and technology, health and so on meet for specialised Council meetings. Each specialised Council establishes a basis for ongoing personal co-operation and negotiation among executives working in the respective policy sector. As a result of the Maastricht Treaty, the Council is also made responsible for intergovernmental co-operation in the fields of common foreign and security policy, justice and home affairs.

The ministers in the Council are leading political figures in their own countries. It is unusual for a politician to be in power for the full duration of the Commission's term without facing interim elections. Electoral uncertainty, crises and general elections may thus have an impact on Community decision-making. According to Lodge, party affiliations may affect the way in which subgroups coalesce on particular issues within the Council and may influence different policy sectors differently ${ }^{7}$. Furthermore, as the 
populations of the member countries become increasingly aware of the importance of Community decision-making, ministers must be concerned about the impact of the decisions made in Brussels on the people back home and about the impact of those decisions on any upcoming elections. To some extent, it may therefore be argued that decision-making in the Community resembles Putnam's idea of a two-level game in which Council ministers are not only international players but national players as well. ${ }^{8}$

The number of days spent on Council meetings has increased from 83 in 1980 to 98 in 1995. The regularity of meetings of individual Councils clearly reflects their importance in the Council system and the extent to which there is Community activity in a specific policy area. In 1995, for example, the most frequent meetings included: fourteen on general affairs, ten on agriculture, nine on finance and economics. The less frequent meetings, numbering no more than three or four were in areas such as labour and social affairs, industry, research, transport, culture and environment. The least frequent meetings, numbering no more than two, were in telecommunications, energy, education, consumer affairs, health, culture, civil protection and tourism ${ }^{9}$. So, health is certainly not among the overarching priorities of the Community. Yet, the meetings of Health Ministers signal that public health has become a Community competence in the 1990s.

Below the level of ministers operates the Committee of Permanent Representatives (COREPER) at ambassador and deputy levels, responsible for preparing the work of meetings of the individual councils. COREPER is assisted by a complicated network of about 180-200 working groups comprising members of the permanent missions of the Member States as well as national civil servants drawn from national bureaucracies. COREPER analyses the proposals coming from the Commission to the Council. It is responsible for judging at what point a dossier needs further consideration by the national experts in the working groups or the point at which a political decision is required by ministers ${ }^{10}$. The result is a complex network of committees linking the Council of Ministers and the Commission to national bureaucracies. This network is also the arena where, in the words of Guy Peters, the bureaucratic politics within the Community take place. ${ }^{11}$

At every level of the Council's operations, the Commission has a representative to present draft texts and to defend its position. Thus, although national positions are voiced in opposition to specific proposals of the Commission, the links between the two institutions mean they can resolve most potential conflict over policy in committee. Some observers note that,

"the 'elevators' of decision move the dossiers up and down this hierarchy of committees, resolving points (without votes) at the lowest level possible".'2

Also, according to those observers, estimates suggest that around 70 per cent of business is agreed at working group level, thus appearing on Part I of the COREPER agenda, with 15-20 per cent of the business agreed by senior officials and passed to the Ministers as ' $\mathrm{A}$ ' points, leaving the Council 10-15 per cent of the business to resolve. In 1995, the number of days spent on meetings of Ambassadors and ministerial 
delegations was 112 whilst 2365 days were spent on meetings of preparatory committees and working parties ${ }^{13}$. With the increase in the number of layers of negotiations bargaining has become more complex. In the view of Wallace,

"the Council of Ministers works within the limitations of a consensusbased system of bargaining and through fragmented channels of decision". ${ }^{14}$

\subsection{Voting Rules}

Changes in the voting rules in the Council have altered its policy-making role and to some extent changed the entire Community. After the so-called Luxembourg Compromise in 1966, Commission proposals could not be pushed to a vote in the Council when disagreements between the Member States existed. Even when the rules of majority voting were applying to the proposals under consideration, the Compromise allowed member governments to prevent agreement by claiming that vital interests were at stake.

The Luxembourg Compromise resulted from the French government's opposition, and in particular President De Gaulle's, to Commission proposals that were linked to the completion of the Common Agricultural Policy. The policy's aims were to give greater powers of control to Parliament, and to change the basis of Community income from national contributions to own resources. When no agreement could be reached in these matters, France withdrew its representatives from the Council. This policy of 'empty chair' lasted for six months and was ended only after the French government agreed to attend a special Council meeting in Luxembourg in 1966. The Compromise was thus an unofficial agreement, but it has been interpreted as meaning that any state has the right to be protected against an adverse majority vote on issues which affect its vital interests, whereby the states themselves determine when such interests are at stake. As a result, negotiations on most issues before the Single European Act had to be continued until unanimous agreement was reached ${ }^{15}$.

The decision rules have been changed by the Single European Act (1987) which introduced the co-operation procedure and changed the voting rule of unanimity by introducing qualified majority voting in the Council. A large number of matters, formerly subject to unanimity, have become subject to qualified majority voting. For a great deal of policy issues, qualified majority voting in the Council has thus removed the formal obstacle posed by the ability of any single member state to veto proposed legislation by the Commission. Policy-making now relies more on coalition building than on national vetoes for protection. The co-operation procedures (extended under the Maastricht Treaty) have not only altered the balance between the Council and member governments on the one hand, and the Commission and the European Parliament on the other hand, they also influenced the Council itself.

The rules governing the use of qualified majority voting were extended to the adoption of measures concerned with the completion of the single market. Qualified majority voting usually also applies to proposals designed to implement an established policy. 
Social security and health care issues still require unanimity, which may be interpreted as an indicator that national viewpoints and interests continue to carry weight. ${ }^{16}$

Under the voting rules for qualified majorities France, Germany, Italy and the UK have ten votes each; Spain has eight; Belgium, Greece, the Netherlands, and Portugal have five; Austria and Sweden have four; Denmark, Ireland and Finland have three; and Luxembourg has two. Of this total of 78 votes, 62 form a qualified majority and 26 a blocking coalition ${ }^{17}$. The underlying rationale of this voting procedure is that the four largest countries cannot make decisions on their own. They always need the support of a minimum of three smaller countries to form a winning coalition. Likewise, the smaller countries cannot force a decision on the larger countries, but need the support of two larger countries to form a winning coalition.

The Council remains at the centre of the stage of European decision-making after the Maastricht Treaty on European Union, but it cannot act alone. As Hayes-Renshaw and Wallace noted,
"it depends on the other institutions to play their parts in the process; it cannot neither control the inputs from the Commission nor dictate the interpretations of its decisions by the ECJ (European Court of Justice). And increasingly is forced to accommodate the preferences of the EP (MEPs) on particular issues"l's.

The Maastricht Treaty introduced the co-decision procedure between the Council and the Parliament, which gives the Parliament a greater influence on policy matters. Significant policy areas are now covered by this new procedure, including internal market legislation, public health, environmental action and the framework programme for research and technological development. In the case of research and development unanimity is required in Council on research and technological development. However, these are all health policy related areas that are covered by this study. A prior knowledge of the co-operation and/or co-decision procedure is important and we will focus on the operation of these procedures in chapter three.

\section{The Commission}

The Commission can be seen as a type of 'government' and 'administration'19. The Treaty of Rome, which established the European Economic Community in 1957, invested it with powers to initiate almost all policy proposals. In the so-called common market policies of the treaty, the Commission even has the exclusive right to introduce legislation to the Council of Ministers. The Council may or may not accept a proposal, but it cannot act without initiation by the Commission. Thus, the initiative is in the hands of the Commission which gives it tremendous influence over the setting and final shape of the policy agenda ${ }^{20}$.

Its role in policy initiation represents the most important policy-making function of the Commission. This role places importance on its mediative and bargaining capacities at the pre-decisional stage of formulating a proposal. It also underscores the ability of the Commission to act as a go-between in bridging differences between the Member States 
and to work on acceptable compromises. In addition, as a guardian of the treaties, the Commission is entrusted with administrative, supervisory and quasi-judicial functions to ensure that the provisions of the treaties and the Community measures resulting from these are carried through into practices ${ }^{21}$.

Apart from its role as an initiator of policies, the Commission has its own direct and indirect rule-making powers. As such, it is in a similar position to national public administrations. It makes secondary legislation governing the operations of the administration of the Community itself. For administrative matters it issues several thousands rules of its own annually. These rules can include significant policy matters such as proposed company mergers, state aids, or price and market support measures in the common agricultural policy. Further, the Commission may carry out investigations and can decide what cases should be submitted to the Court of Justice. Supported by decisions of the European Court of Justice, the Commission has also taken advantage of the rather broadly phrased treaty provisions regarding competition policy to develop the position on restrictive practices and to make rules on its behalf. This is nicely illustrated in the field of public health. Although the Treaty of Rome did not provide the Commission with a public health competence, this did not prevent it from undertaking some action. Through a creative use of its bureaucratic powers, it was able to develop several policy initiatives. ${ }^{22}$

The role of the Commission in policy implementation should be considered as limited because of the fact that it is dependent on the Member States' bureaucracies for executing the final decisions made by the Council of Ministers. ${ }^{23}$ It is here that the analogy between the Commission and public bureaucracy in a nation-state fails. Whilst public bureaucracies are intensively involved in the implementation of public policy, the Commission is less concerned with the direct implementation of laws.

\subsection{Composition and Organisation}

The Commission is an appointed body. It consists of twenty Commissioners who are appointed for a five-year term and can be re-appointed. Its President is chosen through a process of common accord by the member governments. The member governments nominate other members. As a result of the Maastricht Treaty, the Council appoints the President 'after consulting the European Parliament (article 127). Furthermore, the appointees to the Commission are subject, en bloc, to a vote of confidence of the Parliament. This means that it would be difficult for the Council to persist with a nominee who did not receive an affirmative vote from the Parliament. Each of the five larger countries has two Commissioners (France, Germany, Italy, Spain and the United Kingdom. The smaller countries have one each (Belgium, the Netherlands, Luxembourg, Ireland, Portugal, Greece, Denmark, Austria, Finland, Sweden). To a marked extent, the distribution of the policy portfolios among the other nineteen commissioners is a matter of heated discussions, negotiation and political balance.

Although the commissioners are collectively appointed, they are national nominees in practice. There are no rules or general understandings as to what kind of people, with what sort of experience and background, member governments should nominate. In general, it can be said that the member governments tend to nominate their 
commissioners to reflect national political pressures and issues. The five larger countries vary in what they do, but it is common practice to nominate one commissioner from the government party and a second one from the opposition party. The smaller countries tend to nominate somebody from or associated with their larger or their government party. The diverse political composition of the Community's national governments leads to a wide range of political opinions represented in the Commission.

The members are each in charge of particular policy areas and meet collectively as the College of Commissioners. According to the treaty, all its members are equal. In practice, there is a need for leadership that is fulfilled by the Commission President. ${ }^{24}$ It is up to the Commission President to decide whether he (or she) will adopt a technocratic, political or presidential style when providing policy direction to the work of the Commission. ${ }^{25}$ As is well documented, in exercising a political leadership, the Commission President can exert significant influence on the course of integration. Jacques Delors's two and a half term in office is the best manifestation of this potential ${ }^{26}$.

The Commission bureaucracy is divided into twenty-four Directorates General (DGs), usually referred to by their number rather than by their policy area (see table 1). The general model of the hierarchical structure is that commissioners are assigned portfolios and carry the main leadership responsibility in particular policy areas. Directors-general, responsible to appropriate commissioners, head DGs. A proliferation of Directorates and divisions is underneath the top leadership structure. All important matters and policy proposals are channelled through the weekly meetings of the College of Commissioners. Decisions are often taken unanimously, but sometimes also by majority vote.

The content of portfolio responsibilities changes for each Commission. The organisational location of new policy responsibilities may be the subject of bureaucratic dispute among the Directorates, but can be managed without having to alter titles and the organisation chart. ${ }^{27}$ As a result, some DGs have more than one commissioner responsible for part of their work. Further, the structure of DGs reflects a pattern of vertical divisions that discourages the co-ordination of related policy areas. Rather, each DG has been jealous of its competence and is often reluctant to cooperate with other DGs, even when there is an overlap of responsibilities ${ }^{28}$.

Depending on the policy aim, each policy proposal is elaborated within the various departments of the DGs assuming responsibility for the issue under consideration. For instance, most of the proposals for legislation of the pharmaceuticals and medical devices are elaborated within DG III (Industry). Legislative proposals establishing minimum common standards in the field of occupational health emanate from DG V (Employment, Social Affairs and Education). Legislative proposals concerning the coordination of social security systems for workers moving within the EC also came from DG V. Furthermore, legislation proposals initiated by DG XI (Environment, Consumer Protection and Nuclear Safety) and DG XXIV also have important repercussions for public health. Lastly, public health initiatives such as 'Europe 
against Cancer' or 'Europe against AIDS' come from DGV, while research and technology activities are located in DGs XII and XIII.

An emerging policy area such as health is a good example of fragmentation in Community institutions. As was already pointed out in chapter I, health constitutes an area with many different aspects and issues between which clear boundaries do not exist. As a direct consequence, various actors within the European 'machinery' are involved in health policy-making activities. This situation complicates, if not hinders, the development and co-ordination of a coherent European health policy, the more so because each DG will always defend its own policy and institutional interests and will bring in different and often conflicting views in the health policy arena. Institutional fragmentation inevitably adds to the need of political compromises.

The complex and fragmented structure of policy-making on public health was rather dramatically demonstrated in the recent BSE crisis (mad cow disease). A European Parliament's report about the Commission handling of this crisis revealed that 13 of the 24 directorates had direct responsibility for some aspect of the health policy. ${ }^{29}$

Finally, it may be illustrative to refer here to the comments of Vasso Papandreou, a former commissioner for Social Affairs. In the view of the new public health provisions in the Maastricht Treaty she recalled the interest of DGV in health-related problems, but at the same time regretted the lack of a coherent Commission policy, owing to the sharing of competencies on health matters between Social Affairs, Research, the Internal Market and the Environment ${ }^{30}$.

\section{Table 1: Directorates - General of the European Commission}

\begin{tabular}{|l|l|}
\hline & \\
DGI & External Relations \\
DGII & Economic and Financial Affairs \\
DGIII & Industry \\
DGIV & Competition \\
DGV & Employment, Industrial Relations and Social Affairs \\
DGVI & Agriculture \\
DGVII & Transport \\
DGVIII & Development \\
DGIX & Personnel and Administration \\
DGX & Information, Communication, Culture, Audio-visual \\
DGXI & Environment, Nuclear Safety and Civil Protection \\
DGXII & Science, Research and Development \\
DGXIII & Telecommunications, Information Market and Exploitation of \\
DGXIV & Research \\
\hline
\end{tabular}




\begin{tabular}{|l|l|}
\hline DGXV & Internal Market and Financial Services \\
DGXVI & Regional Policies and Cohesion \\
DGXVII & Energy \\
DGXVIII & Credit and Investments \\
DGXIX & Budgets \\
DGXX & Financial Control \\
DGXXI & Customs Union and Indirect Taxation \\
DGXXII & Education, Training and Youth \\
DGXXIII & Enterprise Policy, Distributive Trades, Tourism and Co-operatives \\
DGXXIV & Consumer Policy \\
\hline
\end{tabular}

\subsection{Policy formulation}

The preparation of a policy proposal requires an intense and extensive process of formal and informal consultations with many different actors such as supranational officials, officials from national and regional governments, expert groups, representatives of functional interests and client groups of various sorts. In the formulation phase of each proposal, an important role is played by a vast network of advisory committees, conferences, seminars and workshops. The committees established over the years are of two main types. The first type consists of the expert committees that comprise officials and experts nominated by national governments. Some of those national officials and experts are also members of Council working groups, where the proposals presented to the Council are examined formally. Consultative committees (comprising representatives of sectional interests appointed by the Commission from nominations made by representative Community level organisations) form the second type. The influential role of the expert committees should be considered as the most important since well-prepared consultations in these committees alert the Commission to what governments are likely to find acceptable at the future and final decision-making stage in the Council. ${ }^{31}$.

\subsection{Policy Implementation}

We have already seen that the role of the Commission in policy implementation is limited. National bureaucracies can bargain over a policy and its meaning in Brussels, determining interpretations and even redefining EC policy during implementation. As Richardson emphasised, there are various ways of defeating the aims and objectives enshrined in Community policies, should Member States, implementing agencies and interest groups so wish.

"Public policies may be 'peace treaties' agreed between competing member states, interests and institutions at the time policies are 
adopted, but the signatories to the peace treaties often find ways of not complying with what they have agreed". ${ }^{32}$

As the evidence shows, national legal acts can affect the implementation of Community rules such as directives and indeed alter the meaning of directives in practice. Different effects in implementing identical Community programmes may be explained by specific national interests and decision-making cultures in problemsolving. Empirical research also suggests that there is no development of separate administrative styles and patterns which can be associated to the implementation of EC legislation. The general picture is that the implementation of Community legislation follows the same patterns and meets the same obstacles as the implementation of national legislation. ${ }^{33}$

There are not only cross-national differences, but also major sectoral variation in the degree to which implementation is effective within Member States. Member States may have a good implementation record in one area and a bad record in another area. Hence, Richardson suggests that implementation is inevitably going to be variegated across the Community, as other 'federal' systems have discovered. ${ }^{34}$ He refers, among other examples, to the environmental field, with almost every member state having been brought before the European Court of Justice for non-compliance with certain aspects of Community environmental law. He also refers, to the agricultural sector, "a nightmare in terms of implementation problems". Further, he addresses current attempts by the Commission to encourage or enforce implementation, with the enforcement style being a mixture of persuasion and punishment through fines. In this context, he quotes the environmentalists calling for strengthened powers for the European Court of Justice to impose financial sanctions on Member States, and the strengthening of individual rights to bring actions to enforce against non-compliance.

Another aspect of a failing implementation is Community fraud. After examining a number of cases of Community fraud in the agricultural sector, Mendrinou suggests that fraud should not be seen only as an indicator of corruption. Rather, fraud also should be analysed as a symptom of manifest or latent tensions between the Community and the Member States as well as among Community institutions - the Commission and the European Parliament on the one hand and the Council on the other hand. In addition, Mendrinou suggests that fraud can be seen as a stimulus for change in the organisational structure of the Community. For example, in the attempts of Community institutions to tackle the issue, new structures are created which may eventually lead to a considerable increase in the powers of supranational institutions the Commission, the European Parliament and/or the Court of Auditors ${ }^{35}$.

In the previous chapter, we have briefly discussed the principle of subsidiarity. According to this principle the Commission should propose general framework laws, which should be worked out and implemented by Member States. As Richardson pointed out, subsidiarity may increase the scope of the Member States' discretion to implement Community policies in line with their administrative traditions or systemic non-compliance. ${ }^{36}$ 


\subsection{Interest groups}

The making of Community policy has considerably expanded in recent years. Under the Maastricht Treaty, texts in various policy areas modified, clarified, codified or extended EC competence and had repercussions for its involvement in health. The Community policy framework now incorporates legislation, initiatives and interventions in social policy, environment, consumer protection, public health and research. This has led interest groups and firms to improve their ability to participate in and to influence policy initiation by the Commission. A recent survey highlighted that officials from a range of DGs placed enormous importance on the consultation of interest groups, from problem identification and options search stage through to policy implementation. ${ }^{37}$

Before the introduction of the Single European Act only few associations and companies were involved in systematic attempts to influence the EC institutions. Most of the lobbying was directed towards the national governments that were adopting legislation usually by unanimous agreement in the Council. Understandably, Community interest organisations appeared first in those policies areas for which the Community was given responsibility by the Treaty of Rome. Founded in 1958, the Committee of Professional Agricultural Organisations of the European Community (COPA) is, in a corporatist way, involved in Community policy-making. Each year, the Commission, COPA and the Council decide on the level of support to be granted to the Community's farmers as part of the common agricultural policy. Other important Euro-interest organisations include the Union of Industrial and Employers' Confederations in Europe (UNICE), the European Trade Union Confederation (ETUC), and the European Centre for Public Enterprises (CEEP), representing public employers. In 1980, forty per cent of the interest associations recognised by the Community represented industrial employer interests and one third represented the food and agriculture sectors, totalling 71 per cent of all Euro-interest groups. ${ }^{38}$

The introduction of the Single European Act and its internal market programme provoked an explosive growth of lobbying in the Community. Because of the changes in the Community decision rules, there has also been an enormous growth in lobbying towards the Commission and the European Parliament. A survey in 1985/1986 registered 659 federations, which had a representation in Brussels. Furthermore, about 6000 lobbyists and national interest associations in member countries were considered to be of relevance to Community policy-making. ${ }^{39}$ Andersen and Eliassen estimated that in 1991 only about 30 percent of the interest groups lobbying in Brussels came from industry and agriculture. The new types of actors include associations representing other sectors or business and accounting firms, and representatives of individual firms, national associations, regional associations, cities and diplomats. New actors and business groups who are primarily interested in the regulation of their products or services in the marketplace may be expected to direct most of their lobbying towards the Commission. Interest organisations from other sectors of society such as trade unions, education, culture, social services and the environment numbered 126 , that is 29 percent of all Euro-groups. They have only recently strengthened their representation in Brussels. This can be explained by the growing importance of the 
Community in areas such as the social dimension and the environment. Today, these areas constitute the greatest proportion of organised interests represented in the EC. ${ }^{40}$

The European associations of employees (ETUC), consumers (BEUC), environment (EEB), and public health (the EPHA) direct their lobbying towards the Commission. As all these policy areas are genuinely political, these interest groups also direct a major part of their efforts towards the European Parliament. The European Public Health Alliance (EPHA) was officially launched in 1993, the year the Maastricht Treaty came into force, including the new article 129 on public health. It was initially developed as a sector within the European Citizen Action Service (ECAS) and continues to be affiliated to ECAS. The EPHA is also actively involved in the European Parliament. It co-ordinates the intergroups on public health in the European Parliament.

A recent study has shown that there is only limited evidence of Euro-interest activity in the field of social policy without funding or support from the Commission ${ }^{41}$. According to this study, the discussion about social security in the context of economic and monetary union is based primarily on the reports of the OST (Observatoire Social Européen). The OST, founded in 1984, was the result of a Belgo-Italian initiative of trade unions. The setting up of OST reflected the interest of the trade unions to prepare themselves better for possible future developments. It is a research and documentation centre on the social aspects of European integration aiming at providing empirical data and critical comments to a wide readership including trade unionists, researchers, politicians, officials, journalists and students.

In the 1970s, the Commission set in motion a process to start an ongoing dialogue with the Euro-organisations of labour and industry through the establishment of the Standing Committee on Employment and various Sectoral Committees attached to the Directorate General for Social Affairs (DGV). In the 1980s, it continued its attempts to establish tripartite bargaining, known as the Val Duchesse dialogue, but these attempts have failed to produce any concrete results ${ }^{42}$. In the 1990s, at the Commission's initiative, tripartite bargaining saw a renewed interest in the Social Policy Protocol and the attached Social Agreement, signed by all the Member States, with the exception of the United Kingdom. The new provisions assigned a key role to the social partners in negotiation, agreement and implementation of EC social policy. For the proponents of macrocorporatism, the Social Policy Protocol established the legal basis for a Community model of corporatism. Despite the possibilities for macrocorporatism, there are doubts about whether the EC possesses the institutional and financial means necessary for the maintenance of the protocol and whether the social partners are in the position of fulfilling the functions assigned to them ${ }^{43}$.

Another example of Commission attempts to co-operate closely with interest groups can be found in the debate on technology in the 1980s. The focus of this debate was on the potential loss of European competitiveness in both traditional industries and the more advanced industries vis-à-vis the United States and Japan. When the Commission engaged in policy-making in order to promote the competitiveness of particular industrial sectors, it formed an alliance with individual firms. Sectoral bargaining patterns have been institutionalised. Sectoral industry associations, the so-called 
FEBIs, are now widely recognised as interest groups heavily involved in the policy process from the level of broad industrial debates to the setting of standards and regulation and the allocation of resources within specific research and development programmes. These sectors include, among others, consumer electronics, pharmaceuticals, biotechnology, chemicals, and telecommunications.

\section{The European Parliament}

The European Parliament was first constituted as the Assembly of the European Coal and Steel Community (ECSC). It adopted the name of the "Parliament" in 1962. It initially consisted of members appointed by their national Parliaments. The European Parliament's direct election by universal suffrage was foreseen in the Treaty of Paris (1951) which established the ECSC, but the Member States agreed to introduce direct elections in 1976. The first poll was delayed until 1979. The European Parliament became the first directly elected international parliament in history. ${ }^{44}$

Although the citizens now have a direct electoral relationship with the Members of the European Parliament (MEPs), the powers of the European Parliament are not comparable to those of national legislatures. The members of the national parliaments are elected as members of political parties to support a government, or a potential government. Where the result of an election does not produce a party or coalition with a clear parliamentary majority, the actual formation of a government is often done outside the parliament by a small group of party leaders. In contrast to national parliaments, the European Parliament neither designates the executive, i.e. the Commission and/or Council, nor decides upon their policy programmes. Far from holding exclusive legislative power, the Parliament does not even hold equal decisionmaking power with the Council. ${ }^{45}$

While it is true that the European Parliament's powers are not comparable to those of national legislatures, developments over the years have come to give it, in practice, increasing influence in Community policy-making. Its influence can be seen in relation to four different tasks: through participation in law-making: through the budgetary process; through control and supervision of the executive; and through acting as a forum for debate and expression of view on matters of public concern. ${ }^{46}$

\subsection{Elections}

The European Parliament consists of 626 MEPs. The distribution of the members over the participating nations is presented in table 2 . 
Table 2: The Distribution of the Members of the European Parliament by country

\begin{tabular}{|l|l|l|l|l|l|l|l|l|l|l|l|l|l|l|}
\hline D & F & I & UK & E & NL & B & EL & P & SE & A & DK & FIN & IRL & L \\
\hline & & & & & & & & & & & & & & \\
99 & 87 & 87 & 87 & 64 & 31 & 25 & 25 & 25 & 22 & 21 & 16 & 16 & 15 & 6 \\
\hline
\end{tabular}

Source: Commission Europeenne, Les Institutions de l' Union Europeenne, Office des publications officielles des Communautes Europeennes, 1995.

Contrary to the treaty's provision under article 138 for a uniform electoral procedure (drafted by the Parliament and still to be adopted by the Council of Ministers), the elections of the European Parliament in 1994 were held, like the three preceding elections, on the basis of different electoral arrangements. The majority of Community countries, including Northern Ireland, favour list-system proportional representation on the basis of either multi-member national or regional constituencies. Britain, however, elects its MEPs on a single member constituency, the 'first past the post' majority system. The strong opposition of the British governments in the Council to any form of proportional representation (outside Northern Ireland) has been by far the biggest obstacle to the introduction of a uniform electoral system for the European Parliament elections. Tory hostility is based on the assumption that a proportional system for European Parliament elections would strengthen the campaign for an electoral reform of the Westminster Parliament ${ }^{47}$.

A subject that also has been much discussed in the context of Parliaments elections is voter turnout (see Table 3). In 1979, only 63 per cent of those eligible did so. In most countries the turnout was even lower in the following three general elections. The poll in 1994 was even worse: on average 56 per cent of those eligible did so.

The reduction in the turnout has been attributed to various factors. One such factor is that it is a reflection of the tendencies towards low turn-out in national elections. ${ }^{48}$ Another is a de-Europeanising, or indeed a nationalising, of elections through a lack of a uniform electoral procedure, different rules regarding state funding, limited media coverage and competing national, regional or local elections ${ }^{49}$. Furthermore, national political parties have attempted to play down the importance of European elections and interpret them as unofficial referenda on the national political situation ${ }^{50}$. Yet another explanation of the low turn-outs is that the European Parliament elections do not offer any prospect of change of government and changes in policy in the Community, and consequently do not generate popular interest or political excitement. 
Table 3. European Elections: participation rate (including abstentions and invalid votes) in relation to the total of registered voters

\begin{tabular}{|l|r|r|r|r|}
\hline & $\mathbf{1 9 7 9}$ & $\mathbf{1 9 8 4}$ & $\mathbf{1 9 8 9}$ & $\mathbf{1 9 9 4}$ \\
\hline Germany & 65.7 & 56.8 & 61.5 & 60.1 \\
\hline Denmark & 47.1 & 52.3 & 46.0 & 52.0 \\
\hline France & 60.7 & 56.7 & 49.3 & 52.3 \\
\hline Greece & & 77.2 & 77.7 & 71.0 \\
\hline Ireland & 63.6 & 47.6 & 68.3 & 41.0 \\
\hline Italy & 85.5 & 83.9 & 81.5 & 74.6 \\
\hline Luxembourg & 88.9 & 87.0 & 87.0 & 90.0 \\
\hline Netherlands & 57.8 & 50.5 & 47.2 & 35.6 \\
\hline United Kingdom & 31.6 & 32.6 & 36.0 & 36.6 \\
\hline Spain & & 68.9 & 54.8 & 59.6 \\
\hline Portugal & & 72.2 & 51.2 & 35.7 \\
\hline Belgium & & 92.0 & 90.7 & 87.0 \\
\hline Average & 63.0 & 61.0 & 58.5 & 56.2 \\
\hline
\end{tabular}

Source: P. Delwit et J-M de Waele, Les elections europeennes et l'evolution des groupes politiques au Parlement europee, in M. Telo (ed), Democracie et Construction Europeenne, Editions de l' Universite de Bruxelles, 1995, p 281

\subsection{The European Parliament Party System}

The members of the European Parliament (MEPs) are selected by national parties and then elected within national frameworks. They belong to a Parliament party group. Most of these groups, often referred to as supranational parties, are organised around traditional European political families: Socialists (Party of European Socialists, PES), Christian Democratic (European Peoples Party, EPP), Liberals (Liberal, Democratic and Reformist Group, ELDR), Left (United European Left and Left Unity).

A minimum of twenty-three MEPs of the same nationality is required to form a Parliament party group. If the members come from two countries, the minimum is reduced to eighteen, and if they come from three or more countries the minimum is reduced to twelve.

Table 4 gives a historical overview of the number of seats of the various European Party groups in the Parliament. From the outset of the first European elections and up to the fourth Parliament in 1994, the European Socialists' Party (PES) has remained the largest single group with the Christian Democratic European People's Party the second. 
The political role of the Parliament party groups is different to their national counterparts because they do not support a government or a potential government. The political activity of the party groups, however, should be explicitly linked to the institutional setting of the European Parliament, its power, and its position in the EC inter-institutional relations. In the European Parliament, for example, the need for tactical alliances between party groups subsumes the need for ideological purity. No matter what political issues divide them, majority requirements impose tactical Socialist-Christian Democrat alliances in all sorts of ways - from electing the President to voting on amendments to proposed legislative matters.

Table 4: Evolution of the EP party groups from July 1989 to July 1994

\begin{tabular}{|l|r|r|r|r|r|}
\hline & $\begin{array}{r}\text { July } \\
\mathbf{1 9 8 9}\end{array}$ & $\begin{array}{r}\text { April } \\
\mathbf{1 9 9 2}\end{array}$ & $\begin{array}{r}\text { January } \\
\mathbf{1 9 9 3}\end{array}$ & $\begin{array}{r}\text { January } \\
\mathbf{1 9 9 4}\end{array}$ & $\begin{array}{r}\text { July } \\
\mathbf{1 9 9 4}\end{array}$ \\
\hline $\begin{array}{l}\text { Party of European Socialists } \\
\text { (PES) }\end{array}$ & 180 & 179 & 198 & 198 & 198 \\
\hline European People's Party (EPP) & 121 & 161 & 161 & 162 & 157 \\
\hline $\begin{array}{l}\text { Liberal Democratic and } \\
\text { Reformist Group (ELDR) }\end{array}$ & 49 & 45 & 45 & 44 & 43 \\
\hline European Democrats & 34 & & & & \\
\hline Greens Group & 30 & 27 & 27 & 28 & 23 \\
\hline United European Left (UEL) & 28 & 29 & & & 28 \\
\hline $\begin{array}{l}\text { European Democratic Alliance } \\
\text { (RDE) }\end{array}$ & 20 & 21 & 21 & 20 & 26 \\
\hline Rainbow Group & 13 & 16 & 16 & 16 & \\
\hline $\begin{array}{l}\text { Technical group of the } \\
\text { European Right }\end{array}$ & 17 & 14 & 14 & 13 & \\
\hline Left Unity & 14 & 13 & 13 & 13 & \\
\hline Forza Europa & & & & & 27 \\
\hline European Radical Alliance & & & & & 19 \\
\hline Europe of Nations & & & & & 19 \\
\hline Non-Attached & 12 & 13 & 21 & 24 & 27 \\
\hline Total & 518 & 518 & 518 & 567 \\
\hline
\end{tabular}

Source: C. Lecureil, Prospects for a European Party System after the 1994 European Elections, in J. Lodge (ed), The 1994 Elections to the European Parliament, Pinter, 1996, (p 191) 


\subsection{Organisation of the Parliament}

The European Parliament largely makes its own decisions about its operation and functioning. In practice the responsibility for this falls mainly to the President, the Bureau, and the enlarged Bureau. The Bureau consists of the President and Parliament's fourteen Vice-Presidents, all elected in office for half the Parliament's five year term. For certain key purposes the members of the Bureau are joined by the Party Group's leaders. This constitutes the Enlarged Bureau. Of particular interest is the allocation of positions on the Parliament's permanent committees. There are nineteen of these committees (see Table 5). In practice political groups negotiate the share-out of committee membership on a basis proportionate to their size. The committee meetings of the Parliament are held in Brussels, while its plenary sessions are held in Strasbourg and its secretariat is located in Luxembourg.

After receiving a proposal from the Commission, the Parliament channels this directly to the respective committee. Depending on the policy aim proposals in relation to health are submitted, for example, to the committee for the environment, public health and consumer protection, the committee for social affairs or the committee for science, research and development. In each case, the committee chooses a chairman, the rapporteur, to report to the plenary session. Their views then may be adopted by the plenaries as a motion for resolution constituting the Parliament's formal opinion. The committees can make use of the Parliament's research facilities and staff; draw on outside expertise; send MEPs on fact-finding missions; hold public hearings; and, as necessary, set up sub-committees and committees of inquiry. The debate on institutional changes, prompted by the new public health provisions, raised the issue of fragmentation of health related matters between various Parliament committees. Simone Veil, a French MEP, attempted several times, without success, to set up a specific parliamentary Committee on public health ${ }^{51}$.

\section{Table 5: Standing Committees of the European Parliament}

\section{Committee on Foreign Affairs and Security}

2. Committee on Agriculture, Fisheries and Development

3. Committee on Budgets

4. Committee on Economic and Monetary Affairs and Industrial Policy

5. Committee on Energy, Research and Technology

6. Committee on External Economic Relations

7. Committee on Legal Affairs and Citizens Rights

8. Committee on Social Affairs, Employment and the Working Environment

9. Committee on Regional Policy and Regional Planning

10. Committee on Transport and Tourism

11. Committee on the Environment, Public Health and Consumer Protection 
12. Committee on Culture, Youth, Education and Media

13. Committee on Development and Co-operation

14. Committee on Civil Liberties and Internal Affairs

15. Committee on Budgetary Control

16. Committee on Institutional Affairs

17. Committee on the Rules of Procedure, the Verification of Credentials and Immunities

18. Committee on Women's Rights

19. Committee on Petitions

\subsection{The role of the Parliament in policy-making}

Under the treaty of the European Coal and Steal Community (ECSC) the "Assembly" was granted "supervisory powers" (Article 20 ECSC). It would meet at least once a year (Article 22 ECSC); and a vote of censure by two-thirds of its members would dismiss the High Authority, that is the Commission (Article 24 ECSC). The Assembly had no powers over the Council. It could, however, be invited to express its opinion "on such questions as may be put to it by the Council" (Article 22 ECSC).

The Treaty of Rome (1957) which established the European Economic Community (EEC) did not bring significant changes to the Parliament's powers. Its legislative role was kept limited to render opinions on Commission proposals before the Council took final decisions. The absence of a legislative function restricted the influence of the Parliament on the Community policy-making for many years. Since 1975, the Parliament has made extensive use of its budgetary powers, though limited, to affect the policy choices reflected in proposed Community expenditure.

Following the Single European Act (1987), the Parliament's influence in the legislative process has increased, notably, through the co-operation procedure. Far from acquiring a genuine legislative role, the changes in the decision rules allowed the Parliament, if supported by the Commission, to amend both Council legislation, relating mainly to the establishment of the internal market, and Council decisions relating to the implementation of established policies.

The importance of the European Parliament as a conditional agenda setter has been recognised in recent scholarly work ${ }^{52}$. Case studies have shown that the Parliament has been able to exert significant influence within the areas of environmental policy and research and technological development ${ }^{53}$. Another study concluded that the Committee on the Environment, Public Health and Consumer Protection,

"has consistently sought to involve itself at the pre-legislative stage through a conscious strategy of agenda setting ${ }^{\prime 54}$.

It has the reputation of being exceptional amongst the European Parliament's legislative committees in that it produces a considerable flow of 'own initiative' reports. It has had a notable success in prompting the Commission into legislative 
action. This has prompted a swarm of organised interests - industrial, environmental, and consumer groups - to attend and monitor the committee's meetings.

The European Parliament has been in favour of a Community health policy since the early 1980s and has put forward several resolutions in the field of health, notably: European health card; European Charter of patients' rights; environmental pollution; the ozone layer and air quality; pharmaceuticals; additives; foodstuffs and beverages; the cancer programme; health and safety at work; health and internal market; and health and the environment ${ }^{55}$.

A reference should be made to the several health-related intergroups in the European Parliament. They are informal discussion groups, established by the members of the Parliament, and provide a forum for cross-party debate of important issues. They deal with topics which include, among others, aspects of EC public health policy, health care professions, ageing, disabled people, social exclusion, complementary medicine, pharmaceuticals, bioethics, food and health, land use and food policy, and consumer issues.

There is also the technology assessment unit of the European Parliament, the Scientific and Technological Options Assessment Programme (STOA). The Parliament adopted the Linkohr report on setting up an office for technology assessment in 1985, and STOA was launched under the auspices of the Committee on Energy, Research and Technology in 1987. Its function is to provide the scientific and technical advice for MEPs and Parliamentary committees, which need to assess policy options. These may be options for science and technology policy, or they may be options in other areas such as public health, the environment, industrial policy and biotechnology. Projects launched so far deal with topics, which include, among others, bioethics, technology for the handicapped, food hygiene and public health issues, and vaccines. Since 1990, at the initiative of the European Parliament, a co-ordination network was set up among the Parliamentary Technology Assessment bodies in the Community, including, the STOA, the Parliamentary Office of Science and Technology (United Kingdom), the Netherlands Organisation for Technology Assessment (NOTA), the Technology Board (Denmark), the Parliamentary Office for the Assessment of Scientific and Technological Options (France), the Secretary of the Bundestag, Committee of Inquiry on Technology Assessment and Evaluation ${ }^{56}$.

Finally, as a result of further changes introduced by the Maastricht Treaty, the Parliament acquires a co-legislative role with the Council and can veto proposed legislation relating to the internal market as well as the decisions relating to the establishment of some policies. It is worth emphasising that these rules apply to the adoption of policy actions in the field of public health as well as to policy areas which are significant for public health protection, such as, environment and consumer protection, but also to social issues and to research policy. Inter-institutional dialogue may, therefore become critical for health policy-making. 


\section{European Court of Justice and the European Community Legal Order}

Political scientists have increasingly paid attention to the development of the Community's legal system - the body of law setting out the powers and the responsibilities of the institutions and the Member States and the authority to give independent rulings on what that law is and how it should be interpreted. They sought to provide a political account of the development of this system, its character and the role of the European Court of Justice within $\mathrm{it}^{57}$. Although not itself a state, the Community is more than merely another international organisation. Law provides the basic setting in which decisions are made and these decisions are binding on the Member States and on the nationals of these states. The Community is, therefore, an organisation in which states have voluntarily surrendered their legislative sovereignty, across a broad range of important sectors, to be independent in the determination and application of public policy. Thus, the states are obliged to submit to a legal system over which they do not have control.

It is not easy to assign Community law its rightful place in the legal order and to define the boundaries between it and national legal orders. Unlike a national legal order, the Community legal order relies on the support of the national systems for its operation ${ }^{58}$. The first illustration of the way in which the Community and national legal orders complement each other is the directive: national authorities enforce Community law, typically by enacting relevant legislation through parliament or administrative circulars. According to Nugent, the sources of the Community legal order are to be found in a number of places: the Treaties, Community legislation, international law, the general principles of law, and judicial interpretation ${ }^{59}$.

\section{1 Court of Justice: Powers and Responsibilities}

Like every legal order, the Community legal order provides a system of legal protection to deal with disputes or conflict between Community law and national law as well as to ensure the implementation of the Community law. The core of this system is the European Court of Justice and the associated Court of First Instance- both based in Luxembourg. The Court consists of one judge from each of the fifteen Member States. They are appointed by common accord of the Governments of the Member States for a term of six years, which may be renewed. Nine advocate generals advise the judges on cases brought to the Court. The jurisdiction of the Court of First Instance, established under the Single European Act, is limited to particular areas, such as, competition law or disputes between the Community and its staff.

The Treaty of Rome as well as the other Treaties establishing the EC provide for a Court of Justice to ensure that in the interpretation and application of the Treaty the law is observed (Article 164). A direct implication of this was that the Court, in making its judgements did not only need to regard written Community law, but the general principles of law as well. Written Community law was primarily concerned with economic activity. In this respect, as we shall discuss below, Court judgements had their greatest impact in areas where the Treaties were largely silent, notably, 
fundamental human rights. Articles 169 and 170 envisaged that the Commission or a member state might bring an action in the Court of Justice against a member state if it has failed to meet its Treaty obligations. These provisions centralised the monitoring of the implementation of Community law in the Commission and the Member States and set up potential conflicts between the Commission and Member States, and among Member States as well ${ }^{60}$. Under Article 173, the Court may be called upon to review the legality of the acts of the Council and the Commission and particularly those having binding force by either a member state, the Council or the Commission. In the words of this Article, grounds for annulment are the,

\section{"lack of competence, infringement of an essential procedural requirement, infringement of this Treaty, or any rule of law relating to its application, or misuse of powers".}

Article 173 also allows, although on a restricted basis, any 'natural or legal' person to invoke review. However, should the Council or the Commission fail to act on a matter provided for by the Treaty, Article 175 envisaged that the Member States, other Community institutions and, in restricted cases, any 'natural or legal person' may bring an action before the Court to have the infringement established.

Article 177 provides that should questions of interpretation of the Treaty or the validity and interpretation of the acts of the institutions of the Community arise before any national court or tribunal, the national court or tribunal may apply to the Court of Justice for a preliminary ruling. Without Article 177 it would have been difficult for individuals to both raise matters of Community law before their national courts and have the interpretation of Community law referred to the Court of Justice. However, it is the exclusive prerogative of the national judge to apply for a preliminary ruling and they do this so frequently that preliminary rulings now constitute the largest category of cases that come before the Court.

\subsection{The Court of Justice: Direct applicability, direct effect and primacy of Community Law}

It is widely recognised that the Court of Justice has played a crucial role in altering the legal character of the Community from that negotiated by the Member States ${ }^{61}$. As early as 1963, the Court declared that the Treaty of Rome constitutes a new legal order of international law that limits the States' sovereign rights. The Court also stated that Community law may confer rights or obligations on individuals which national courts are bound to recognise and enforce (case 26/62, Van Gend en Loos, 1963, ECR 1 at 12). In other words, the Court introduced the concept of "direct effect", i.e. that Community law as such creates rights within the legal systems of the Member States. In consequence, individuals could rely on Community legislation without requiring to implement national legislation. Although one form of Community legislation - the Regulation - is 'directly' applicable, the notion that Community law might have a "direct effect" in the legal systems of the Member States was not present in the Treaty. Equally, the Treaty did not contain explicit reference to the primacy or precedence of Community law over national law. A year after the Van Gend case, the Court proclaimed in the Costa case $(6 / 64,1964$, ECR 585) the supremacy of Community law 
in the event of conflict between that law and national law. As a result of the attribution of direct effect to Treaty provisions, the Court gradually extended, in subsequent cases, the direct effect principle to other forms of Community legislation, notably, directives and decisions.

According to Wincott, the process of establishing and extending the doctrines of direct effect and supremacy lies at the heart of what has to come be known as the 'constitutionalisation' of the Treaty. And as political scientists come to take the Court of Justice seriously in the analysis of European integration, the sense of a teleological legal process of ever closer union may be "swallowed whole". However, the process of 'constitutionalisation' does not inevitably follow-on once the initial steps have been taken, as the legal literature tends to conclude. Wincott warns that the fact that the Court has played a crucial role in European integration, should not be allowed to cover over the fact that even these founding doctrines had to be constructed ${ }^{62}$.

After these founding doctrines were established, the fact remained that the Treaty was not a constitution. Lengthy negotiations between the European Court and national Constitutional Courts took place over the issue of primacy of the Community's legal order. In October 1967, a decision by the German Constitutional Court questioned the democratic legitimacy of the Community's legal order and rejected its primacy over the national systems. The decision stated that the transfer of powers to the Community could not deprive (in this case German) citizens of the protection afforded them by national constitutional provisions on human rights. In other words, the Treaty of Rome contained no protection of human rights and thus, human rights could not be effectively protected by the Community legal order. Similar reservations were expressed by the Italian Constitutional Court some years later. Over a number of cases the European Court of Justice reversed this threat to its authority into an opportunity to develop a system for the protection of human rights. First the Court placed the protection of fundamental rights as a general principle of Community law and then developed its jurisprudence. It gradually found more plausible sources on which to draw, such as the European Convention on Human Rights and what it called 'constitutional traditions of the Member States' ${ }^{63}$.

\subsection{Judicial interpretation: The Court in the European Policy Process}

For the reasons explained earlier the Court has played a crucial political role in establishing, developing and broadening the Community's legal order, especially during the $60 \mathrm{~s}$ and the $70 \mathrm{~s}$. Certainly, the Court's ability to make policy is nonexistent. It can, however, have a significant impact on policy, usually by issuing judgements in many fields of apparent as well as restricted or marginal Community competence. For example, in cases of appeal and/or cases involving preliminary rulings on points of Community law that have been referred to it by national courts, the Court fills gaps in the law and creates new laws in relation to many Community policy areas.

In the area of the free movement of goods which was an explicit field of Community competence since its establishment, a particularly influential Court judgement was issued in 1979 in the Cassis de Dijon case (Case 120/78). In this case the Court 
established the principle of 'mutual recognition' and ruled that national food standards legislation can not be invoked to prevent trade between Member States unless it is related to "public health, fiscal supervision, and the defence of the consumer". Challenges to the principle of 'mutual recognition' were not ruled out. 'Mutual recognition' proceeded slowly and Member States continued to invoke health protection as a ground for a ban on imports. The Cassis case nurtured debates on the desirability of the 'mutual recognition, the free movement of goods and the subsequent harmonisation of national health and safety legislations and became an emblem of the internal market programme.

Community provisions on social security entitlements of migrant workers and members of their families provide another example of mutual recognition. In this area Member States wished to co-ordinate national social security systems and remove obstacles to the free movement of workers, but were unwilling to harmonise or establish Community social security standards. However, since the establishment of the Community and its provisions on social security, the Court has delivered 300 judgements on their interpretation ${ }^{64}$. This number clearly demonstrates that even with the limited scope and range of these Community provisions, their application to individual cases and their interpretation with regard to national law, were in practice far from evident. It clearly indicates also that the Court of Justice made a crucial difference in raising the issue of social security rights of citizens exercising their right to move and to stay within Europe.

The Commission reported in 1992 that few cases relating to health insurance entitlements (in particular the supply of medicines, dental and hospital services) have come before the Court ${ }^{65}$. However, the Court issued two influential judgements in 1998. These judgements may serve to illustrate the role of the Court in favouring the interpretation of Community rules concerned with the free movement of goods and services (art. 30 and art. 59). The interpretations eventually expanded their application on social security institutions, allowing insured persons to go to another Member State to receive services, even without prior authorisation of the competent social security institution. In the Decker's case (C-120/95) the Court ruled that articles 30 and 36 of the EC Treaty preclude national rules under which a social security institution of a member state refuses to reimburse an insured person on a flat-rate basis the cost of a pair of spectacles with corrective lenses purchased from an optician established in another member state, on the ground of the authorisation is required for the purchase of any medical product abroad. In the Kohll's case (C-158/96), the Court ruled that articles 59 and 60 of the EC Treaty preclude national rules under which reimbursement, in accordance with the scale of insurance, of the cost of dental treatment provided by an orthodontist established in another member state is subject to prior authorisation by the insured person's social security institution.

\section{Summing up and conclusions}

In general terms, it may be said that the formal institutions established by Treaty of Rome and the rules governing the relationships of those institutions, indicated a pattern of policy and policy-making in which the Commission would propose, the 
Parliament would advise, and the Council would decide. However, changes introduced by the Single European Act and the Treaty on European Union altered the policy agenda of the EC, the locus of decision-making (supranational versus intergovernmental) and the relationships between the three institutions.

The Member States acting within the Council of Ministers retain the final powers in making policy decisions and legislation in the Community. Thus, the main source of democratic legitimacy of EC decisions lies in the Council representing national governments, based on national parliaments. As a result of changes in voting rules, decision making in the Council relies more on coalition building than on national vetoes for protection for a large number of significant policy matters.

The Commission can be seen as both a kind of government and a kind of administration. It is a body appointed by the member governments and has only an indirect and vague representation through the European Parliament. The Commission is involved in EC policy-making at all levels and in relation to nearly all types of issues, from problem identification to options search stage. The Council may or may not accept a proposal, but it cannot act without initiation by the Commission. The Commission's agenda-setting role clearly represents its most important policy-making function.

An emerging policy area such as a health is an obvious example of fragmentation within the Commission and in the other institutions as well. For example, depending on the policy aim, the proposals related to health matters are prepared by the Directorates concerned with internal market, environment, consumer affairs, social affairs and research. Where responsibilities overlap, the directorates concerned may have developed different or competing views as to what should be done. They may also define health-related issues in a way that best suits one organisation or another. The role of the Commission in policy implementation is limited. National bureaucracies have great power over its implementation as it takes place in line with their administrative traditions.

The European Parliament, directly elected since 1979, is the only institution based on direct popular legitimacy. The European Parliament neither designates the executive, i.e. the Commission and/or Council, nor decides their programme. The absence of a legislative function has impeded any major impact on the establishment of policies until recently. The lack of coherence of most of the party groups and internal majority requirements further constrained the development of party-ideological positions on EC policy choices. However, after the introduction of the Single European Act, second readings, and the co-operation procedure allow the European Parliament together with the Commission to make amendments to Council legislation. The Parliament's powers of co-decision with the Council were increased by the Maastricht Treaty over a range of policy issues, including health policy issues. In addition, the Parliament has increasingly sought to involve itself in a conscious strategy of agenda-setting. Its Committee on Environment, Public Health and Consumer Protection has a good reputation in doing so.

Law, however, provides the basic setting in which Community decisions are made. The Community is, therefore, an organisation in which Member States have 
voluntarily surrendered part of their legislative sovereignty in the determination and application of public policy. The Community's legal order provides a system of legal protection to deal with disputes or conflict between the Community law and national law as well as ensure the implementation of the Community law. The core of this system is the European Court of Justice and the associated Court of First Instance, which are both based in Luxembourg. The Court has played a crucial political role in establishing, developing and broadening the Community's legal order, especially during the $60 \mathrm{~s}$ and the $70 \mathrm{~s}$. This role has been often associated with the process of establishing and subsequently extending the doctrines of direct effect and supremacy, which have to come be known as the process of 'constitutionalisation' of the Community Treaty. Furthermore, while the Court's ability to make policy is not existent, through judicial interpretation, fills gaps in law and creates new laws in relation to many policy fields of apparent, restricted and/or marginal Community competence. We referred to cases concerning the free movement of goods, provisions on social security entitlements of migrant workers and, and the provision of medical goods and services to insured persons within the Community, even without prior authorisation of the insured person's national social security institution.

Finally, the making of EC common policy has increasingly led interest groups and firms to systematically attempt to influence the Commission and Parliament over recent years. These include European associations of employees, consumers, the environment and public health. In addition, the Commission has actively encouraged, through funding and support, the formation of Euro-interest groups in relation to all those issues. Furthermore, the Maastricht Treaty has established an institutional framework for tripartite bargaining among the Euro-organisations of industry and labour, the Commission and the Council to discuss social policy issues. Sectoral industry associations are heavily involved to influence policy initiation by the Commission, from the level of broad industrial debates to the setting of standards and regulation and the allocation of resources within specific research and development programmes. These sectors include, among others, consumer electronics, biotechnology, pharmaceuticals and chemicals.

\section{Chapter Two References}

1. The New Institutionalism: Organizational Factors in Political Life, American Political Science Review, Vol. 78, pp 734-749, 1984 (p 745).

2. See N. Nugent, The Government and Politics of the European Community, London: Macmillan 1989. J. Lodge, The European Community and the challenge of the future, London: Pinter Publishers, 1989. A. Sbragia (ed), Euro-politics: Institutions and Policymaking in the "New" European Community, Washington D. C.: The Brookings Institution, 1992. J. Richardson (ed), European Union, Power and Policy-making, London and New York: Routledge, 1996. M. Telo (ed), Democracie et Construction Europeenne, Editions 1 de l' Universite de Bruxelles, 1995. 
3. D. Curtin, The Constitutional Structure of the Union: A Europe of Bits and Pieces, Common Market Law Review 30, 1993, PP 17-69 (p 34).

4. B. Guy Peters, Bureaucratic Politics and the Institutions of the European Community, in A. Sbragia (cd), Europolitics: Institutions and Policymaking in the "New" European Community, Washington DC: The Brookings Institution, 1992.

5. N. Nugent, The Government and Politics of the European Community, London: Macmillan, 1989.

6. J. Lodge, EC Policy Making: institutional considerations, in J. Lodge (ed), The European Community and the Challenge of the future, London: Pinter Publishers, 1989.

7. J.Lodge, The European Community and the challenge of the future, London: Pinter Publishers, 1989.

8. R.D. Putnam, Diplomacy and domestic politics: The logic of two-level games, in: International Organization, vol 42, Summer 1988, p. 427-460.

9. Council of the European Union, The Secretary-General's Report 1 January-31 December 1995, Luxembourg, 1997.

10. G. Edwards, National sovereignty Vs integration? The Council of Ministers, in J. Richardson (ed), European Union, Power and Policy-making, Routledge, 1996.

11. B. Guy Peters, Bureaucratic Politics and the Institutions of the European Community, in A. Sbragia (ed), Euro-politics: Institutions and Policymaking in the 'New' European Community, Washington D.C: The Brookings Institution, 1992.

12. F. Hayes-Renshaw and H. Wallace, Executive power in the European Union: the functions and limits of the Council of Ministers, Journal of European Public Policy, 1995, pp 559-582.

13. Council of the European Union, The Secretary-General's Report 1 January-31 December 1995, Luxembourg, 1997.

14. H. Wallace, Negotiation, Conflict and Compromise: The Elusive Pursuit of Common Policies, in H. Wallace, W. Wallace and C. Webb (eds), John Wiley and Sons, 1983.

15. N. Nugent, The Government and Politics of the European Community, London:Macmillan 1989.

16. C. Altenstetter, Health Policy Regimes and the Single European Market, in: Journal of Health Politics, Policy, and Law, vol. 27, Winter 1992, pp. 813-846.

17. Commission Europeenne, Les Institutions de l' Union Europeen, Office de publications officielles des Communautés européennes, Luxembourg, 1995.

18. F. Hayes-Renshaw and Helen Wallace, Executive power in the European Union: the functions and limits of the Council of Ministers, Journal of European Public Policy, 1995, pp 559-582, p.562.

19. K. A. Alison, Legitimacy, Effectivity and the Europeification of National Policy-Making, in M. Telo (ed), Democratie et Construction Europeenne, Bruxelles: Editions de l' Universite de Bruxelles, 1995. 
20. B. Guy Peters, Bureaucratic Politics and the Institutions of the European Community, in A. Sbragia (ed.), Euro-politics: Institutions and Policymaking in the "New" European Community, Washington D.C.: The Brookings Institution, 1992.

21. F. Vibert, Europe: A Constitution for the Millennium, England: Dartmouth Publishing Company, 1995.

22. M. Richonnier, Following the U.S. Example : How the European Community went into Public Health, in L. Fahey, Winning in the New Europe, taking advantage of the Single Market, Prentice Hall, 1992.

23. H. Siedentopf and J. Ziller (eds), Making European Policies Work: The Implementation of Community Legislation in the Member States, Vol. I, Comparative Syntheses, European Institute of Public Administration, London: Sage Publications, 1988.

24. T. Christiansen, A maturing bureaucracy? The role of the Commission in the policy process, in J. Richardson (ed), European Union, Power and Policy-making, London and New York: Routledge, 1996.

25. J. Lodge, EC Policymaking: institutional considerations, in J. Lodge (ed), The European Community and the challenge of the future, London: Pinter Publishers, 1989.

26. N. Nugent, The leadership capacity of the European Commission, Journal of European Public Policy, 2:4, December 1995, pp 603-23.

27. N. Nugent, The Government and Politics of the European Community, London:Macmillan 1989.

28. H. Wallace, Negotiation, Conflict and Compromise: The Elusive Pursuit of Common Policies, in H. Wallace, W. Wallace and C. Webb (eds), John Wiley and Sons, 1983.

29. See, Report of the Temporary Committee of Inquiry into BSE, European Parliament, A40020/97; The recommendations of the Temporary Committee of Inquiry into BSE, summarised by Rapporteur: Reimer Boge, Working Document No 1 of 15 May 1997, European Parliament 221.135; Report on the European Commission's follow-up of the recommendations made by the Committee of Inquiry into BSE, Rapporteur: R. Boge, European Parliament, A4-0362/97

30. European Parliament, Intergroup on Health meeting with Commissioner Papandreou in January 1991, minutes by the secretariat: European Public Health Alliance.

31. N. Nugent, The Government and Politics of the European Community, London:Macmillan 1989.

32. J. Richardson, Eroding EU policies, implementation gaps, cheating and re-steering, in idem (ed), European Union, Power and Policy-making, London and New York: Routledge, 1996, p 278.

33. Siedentopf and Ziller, Making European Policies work, The Implementation of Community Legislation in the Member States, Vol. I, Comparative Syntheses, European Institute of Public Administration, London: Sage, 1988.

34. J. Richardson, Eroding EU policies, implementation gaps, cheating and re-steering, in J. Richardson (ed), European Union, Power and Policy-making, London and New York: Routledge, 1996, p. 278. 
35. M. Mendrinou, European Community fraud and the politics of institutional development, European Journal of Political Research, 26, 81-101, 1994.

36. J. Richardson, Eroding EU policies, implementation gaps, cheating and re-steering, in idem (ed), European Union, Power and Policy-making, London and New York: Routledge, 1996.

37. S. Mazcy and J. Richardson, The logic of organisation, interest groups, in J. Richardson (cd), European Union: Power and Policy-Making, London and New York: Routledge, 1996.

38. A. B. Philip, Pressure Groups in the European Community, in R. Beuter and P. Taskaloyannis (eds) Experiences in Regional Co-operation, Maastricht: European Institute of Public Administration, Quoted from S. S. Andersen and K. A. Eliassen, Complex Policy-Making: Lobbying the EC, in S. S. Andersen and K. A. Eliassen (eds), Making Policy in Europe: The Europeification of National Policy-making, Sage, 1993.

39. B. Morris, K. Boehm and M. Vilcinskas, The European Community: A Practical Directory and Guide for Business, Industry and Trade, London: Macmillan, 1986 , quoted from S. S. Andersen and K. A. Eliassen, Complex Policy-Making: Lobbying the EC, in S.S.Andersen and K. A Eliassen (eds), Making Policy in Europe: The Europeification of National Policy-making, Sage, 1993.

40. S. Andersen and K. A. Eliassen, Complex Policy-Making: Lobbying the EC, in idem (eds), Making Policy in Europe: The Europeification of National Policy-making, Sage, 1993.

41. L. Cram, Policy-making in the European Union, London and New York: Routledge, 1997.

42. M. J. Gorges, Interest Intermediation in the EC After Maastricht, in A. W. Cafruny and G. G. Rosenthal, The Maastricht Debates and Beyond, Longman, 1993.

43. ibid

44. A. Duff, Building a Parliamentary Europe, in M. Telo (ed), Democracie et Construction Européenne, Editions de l' Université de Bruxelles, 1995.

45. R. Ladrech and P. Brown-Pappamikail, Towards a European Party System?, in M. Telo (ed), Democratic et Construction Européenne, Editions de l' Université de Bruxelles, 1995.

46. N. Nugent, The Government and Politics of the European Community, London: Macmillan, 1989.

47. A. Duff, Building a Parliamentary Europe, in M. Telo (ed), Democracie et Construction Européenne, Editions de l' Université de Bruxelles, 1995.

48. ibid

49. J. Lodge, The European Parliament - from 'assembly' to co-legislature: changing the institutional dynamics in the EC, in idem (ed), The European Community and the Challenge of the Future, London: Pinter publishers, 1989. 
50. P.Delwit et J.M. de Waele, Les elections europeennes et l'evolution des groupes politiques au Parlement europeen, in M. Telo (ed), Democracie et Construction Europeenne, Editions de l' Universite de Bruxelles, 1995.

51. EP, Intergroup on Health, The intergrpoup's role and activities, minutes of the secretariat: Public Health Alliance.

52. C. Tsebelis, The power of the European Parliament as a conditional agenda setter, American Political Science Review, Vol. 88, No 1, March 1994, pp 128-142.

53. D. Judge, D. Earnshaw and N. Cowan, Ripples or Waves? the European Parliament in the European Community policy process, Journal of European Public Policy, 1: 1 June 1994, pp 27-52.

54. D. Judge, 'Predestined to Save the Earth' : The Environment Committee of the European Parliament, European Parliament: Directorate General for Research, Environment, Public Health and Consumer Protection Series, Working Document-3, 1993.

55. European Parliament, Report of the Committee on the Environment, Public Health and Consumer Protection (Rapporteur: Ken Collins), on Public Health after Maastricht, PE 205.804/fin, 20 October 1993.

56. The Commission of the European Communities in co-operation with the Italian Ministry of University and Scientific and Technical Research, European Parliamentary Technology Assessment-EPTA-, The 2nd European Congress of Technology Assessment, Milano, 14-16 November, 1990.

57. See Nugent, The Government and the Politics of the European Community, London:Macmillan 1989; M. Shapiro, The European Court of Justice, in A. M. Sbragia (ed), Euro-politics, Institutions and Policymaking in the "New" European Community, Washington, D.C.: The Brookings Institution, 1992; D. Wincott, The role of law or the rule of the Court of Justice? An 'institutional' account of judicial politics in the European Community, Journal of European Public Policy 2:4, December 1995, p 583-602; D. Wincott, The Court of Justice and the European policy process, in J. Richardson (ed), European Union, Power and Policy-making, London and New York: Routledge, 1996.

58. Klaus-Dieter Borchardt, the ABC of Community Law, European Documentation (fourth edition), Luxembourg: Office for the Official Publications of the EC, 1994.

59. See Nugent, The Government and the Politics of the European Community, London:Macmillan 1989

60. D. Wincott, The role of law or the rule of the Court of Justice? An 'institutional' account of judicial politics in the European Community, Journal of European Public Policy 2:4 December 1995: 583-602.

61. See M. Shapiro, The European Court of Justice, in A. M. Sbragia (ed), Euro-Politics, Institutions and Policymaking in the "New" European Community, Whasington, D.C.: The Brookings institution, 1992; D. Wincott, The Court of Justice and the European policy process, in J. Richardson, European Union, Power and Policy-Making, London and New York: Routledge, 1996.

62. D. Wincott, The role of law or the rule of the Court of Justice? An 'institutional' account of judicial politics in the European Community, Journal of European Public Policy 2:4 December 1995: 583-602, p 591. 
63. For human rights in the Treaties, including the case-law of the Court of Justice see Christian Duparc, The European Community and human rights, Commission of the EC, Luxembourg: Office for Official Publications of the European Communities, 1993.

64. European Commission, Your social security rights when moving within the European Union: A practical guide, Luxembourg: Office for Official Publications of the European Communities, 1995.

65. Commission of the European Communities, Social security for persons moving within the Community, Social Europe 3/92, Luxembourg: Office for the Official Publications of the European Communities. 



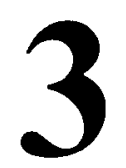

\section{Community}

\section{Policy-Making:}

\section{Fundamental Political Processes}




\section{Introduction}

The aim of this chapter is to provide a brief insight into the nature of Community legal acts, the institutional procedures for their adoption and the budgetary resources at the Community's disposal in the health field. It was indicated earlier that the record of policy outcomes in the health field presents several puzzles in different Community policy areas, for example single market, environment, consumer protection, social affairs and research. The pattern of policy-making varies considerably from sector to sector depending, for example, on the extent of the Community's authority and the type of policy instruments available to the disposal of Community institutions, legal or financial, for pursuing a given policy objective. The policy instruments provided in the health field consist of a capacity to frame common legislation and finance some activities.

With respect to the adoption of the legally binding acts in the health field, we describe and analyse three legislative procedures: the consultation procedure, the co-operation procedure and the co-decision procedure. As far as the Community budget is concerned, we concentrate on the rules governing its revenue, the size of the resources at the Community's disposal, their allocation among the Community policy fields and the procedure to adopt the annual Community budget.

\section{The Legislative Process}

Generally, the legal acts adopted by the Council or the Commission may take one of the different forms described by the article 189 of the EC Treaty. It is worth quoting this article in full,
"In order to carry out their task the Council and the Commission shall, in accordance with the provisions of this Treaty, make regulations, issue directives, take decisions, make recommendations or deliver opinions.

A regulation shall have general application. It shall be binding in its entirety and directly applicable in all Member States. A directive shall be binding, as to the result to be achieved, upon each Member State to which it is addressed, but shall leave to the national authorities the choice of form and methods. A decision shall be binding in its entirety upon those to whom it is addressed. Recommendations and opinions shall have no binding force."

Thus, recommendations and opinions do not bind member states. Nor do they formally constitute part of Community law whereas regulations, directives and decisions do. Regulations are binding in their entirety and take immediate legal effect across the Community once adopted, that is, without the need for national implementing measures. Directives are not binding in their entirety but only in "the result to be achieved". That is, they establish certain policy principles and allow each member state a given period to implement them, typically by enacting relevant legislation 
through parliament or relevant administrative circulars. Lastly, decisions are directed at those parties involved in a particular issue.

The Commission has its own direct and indirect rule-making powers and issues several thousands of administrative measures each year. Most of these are issued in the form of regulations and decisions. Administrative measures may be concerned with significant policy matters, such as competition policy and price supports in the common agricultural policy. However, the member states acting within the Council of Ministers retain the final powers in adopting common or at least approximation measures for the establishment and functioning of the internal market. These measures are usually enacted in the form of Council Directives. As we shall discuss in chapter five, the regulation of the common market did create pressures to expand the scope of Community health legislation in a number of fields that were previously the responsibility of national governments. Regardless of whether such acts would be treated, in national law, as having a legislative, regulatory, or administrative character, Community Directives now concern medicines, the environment, consumer protection as well as the working environment and occupational health and safety. Formal Council approval is also required to establish specific or general action programmes, to modify and further develop an existing policy framework, for example, in the field of public health, environment, consumer protection and research. In this respect, legislation mainly takes the form of Council Decisions. In the following section, we focus on the procedures to be followed by the Community institutions to adopt Directives or Decisions in the health field.

\subsection{Community legislative procedures: From consultation to co-decision}

According to the Treaty of Rome and its consultation procedure, the Commission has the exclusive right to introduce proposals for Council legislation. The Council takes the final decision, generally by a unanimous vote. In the consultation procedure the European Parliament must be consulted before a final decision by the Council. That is to say, Parliament is asked for an opinion on Commission proposals for Council legislation on only one occasion. The Council is under no obligation to take Parliament's amendments into account, and in practice the Council has often acted with little regard for Parliament's wishes'. From the establishing treaty of the Community until today, the workings of the consultation procedure apply to provisions relating to fiscal provisions and to the social security rights of migrant workers and their dependants. Legal binding acts take the form of regulations. We will discuss their implications for the Community co-ordination of national social security systems in Chapter five.

Under the Single European Act (1987), the traditional system of only one reading or consultation remained for most treaty articles. The Single European Act introduced the co-operation procedure, set out as article $189 \mathrm{c}$ of the treaty, for some ten articles relating mainly to the adoption of directives for the establishment of the internal market. In this harmonisation process, Article 100a of the Single European Act has been the most important legal instrument. Article 100a has also provided the legal basis to adopt health and safety standards for the production of pharmaceuticals, their 
marketing and post marketing control. It has been the primary source for task expansion to harmonise measures that are now concerned with environmental protection, consumer protection and public health. In addition, the co-operation procedure covers article $118 \mathrm{~A}$ that deals with the setting of minimum Community standards in the field of occupational health and safety.

First, and most importantly, the co-operation procedure changed the voting rule of unanimity by introducing qualified majority voting in the Council. Qualified majority voting was designed to remove the ability of any single member state to veto proposed legislation by the Commission and thus to facilitate the passage of directives relating to the harmonisation or approximation of national regulations for the establishment of the common market. Secondly, the co-operation procedure added a second reading for both Parliament and Council to the consultation procedure. In its first reading the Council is confined to adopt an initial common position on the Commission's proposal by qualified majority. This common position must be sent back to the Parliament for a second reading. The Parliament may accept, reject or propose amendments (by an absolute majority of its component members) to the Council's common position, which the Commission may incorporate into its proposal to the Council or reject. Parliament amendments that are rejected by the Commission require a unanimous vote by the Council to be incorporated in the final decision. If the Commission decides to incorporate the amendments into its own proposal, the Council requires a qualified majority vote to accept the proposal. In effect, the Commission can only formally amend its proposals. Furthermore, rejected legislative proposals by Parliament can still become law by a unanimous vote in the Council.

Under the co-operation procedure, Parliament continues to lack a genuine legislative role at second readings. Yet, this procedure encourages the Commission to take the views of the European Parliament seriously. In general, the Commission, on average, accepts between 70-80 per cent of Parliament's amendments at the first reading stage 2 , whereas the Council, on average, retains 50 per cent of the amendments at the first reading and 25 per cent at the second reading stage ${ }^{3}$.

In addition to these two procedures, the Maastricht Treaty introduced a third procedure, the co-decision procedure set out in article $189 \mathrm{~b}$, as well as a large number of variants of both the co-operation and co-decision procedure. In contrast to an act adopted by the consultation or co-operation procedures, which is simply an act of the Council, an act resulting from this new procedure is adopted jointly by the European Parliament and the Council ${ }^{4}$. The co-decision procedure replaced the co-operation procedure for some of these articles relating to the establishment and functioning of the internal market and, notably, to measures adopted under the general legal basis of article 100a. The new procedure also covers the adoption of specific and general action programmes in many policy areas, including public health, environment, consumer protection, and the general framework programme for research. All recent public health programmes (for example, Europe against cancer, Europe against AIDS) have been adopted through this procedure and, notably, all have been subject to conciliation between the Council and the European Parliament. In all cases, the budget was the major issue at stake and Parliament achieved additional financing in all conciliations on public health. It appears necessary to examine its workings in practice. 
The co-decision procedure follows the existing co-operation procedure as far as the adoption of the position by the Council at the end of the first reading. That is, after the Commission has submitted a proposal to both the European Parliament and the Council, after the European Parliament has forwarded its opinion to the Council, the Council has adopted a common position acting by a qualified majority. The common position is then communicated to the European Parliament. Once the Parliament has received the common position, it has three months to approve it or it can take no decision, in which case the Council adopts the act in question as it stands.

If the Parliament indicates, by an absolute majority of its members, an intention to reject the common position, the Council can then convene a meeting of a Conciliation Committee to explain its position and thus to try to effect compromise solution at this stage. If no meeting is called or if the Parliament confirms, by an absolute majority of its members, that it rejects the common position, the proposed act is deemed not to have been adopted. Alternatively, the Parliament may propose amendments to the common position by absolute majority which are forwarded then to both the Council and the Commission. If, within three months, the Council, acting by a qualified majority, approves all the amendments, it adopts the act in question. However, the Council acts unanimously to adopt Parliament amendments which have been rejected by the Commission. If the act in question does not meet the approval of the Council, the Council can then convene a meeting of the Conciliation Committee.

The Committee, when convened in both cases mentioned above, has the task to agree on a joint text within six weeks, by a qualified majority of the members of the Council or their representatives and by a majority of the representatives of the European Parliament. In the Conciliation Committee, the 15 members of the Council face 15 members of the Parliament. In fact a sitting of the Conciliation Committee comprises over 100 people on average ${ }^{5}$. If a joint text is agreed, it is then subject to the approval of both the Council of Ministers and the European Parliament. Both the Council and the Parliament have then a period of six weeks to approve it, the Council acting by qualified majority and the Parliament acting by an absolute majority of the votes cast. If one of the two institutions fails to approve, the act is deemed not to have been adopted.

If the Conciliation Committee fails to reach an agreement on a joint text, the Council has the power, acting by a qualified majority, to adopt the common position agreed before the Conciliation Committee was convened, with the possibility of including certain amendments proposed by the European Parliament. In this case, the Council text then stands, unless the Parliament, within six weeks of the date of the confirmation by the Council, rejects the text by an absolute majority of its members, in which case the act is deemed not have been adopted. ${ }^{6}$

From the perspective of the democratic legitimacy of the Community legislative process, the co-decision constitutes an improvement over the co-operation and certainly over consultation procedure. To use the words of Curtin, however,

"if the co-operation procedure pre-Maastricht was described as a real 'ceremonial chinois' in terms of its complexity, one shudders to 
In effect, the co-decision procedure gives a full veto to the European Parliament that may only be persuaded not to exercise its use by a process of conciliation. As a result, the influence of the Parliament over the Community law-making is increased. In addition, the influence of the Parliament over the establishment of policies, which in the past has always been very limited, has also been enhanced. Lastly, interinstitutional ideological dialogue may become critical as the co-decision procedure applies to many policy areas that have a strong ideological profile: free movement of workers, social policy, public health, culture, education, environment and consumer protection.

\section{The Budgetary Process}

\subsection{Revenue and Expenditure}

The fundamentals of the budgetary process in the Community are set out by the financial provisions (articles 199 to 209) of the Treaty of Rome, as amended by the Luxembourg Treaty of April 1970, and the Brussels Treaty of July 1975. The 1970 Treaty of Luxembourg established a Community system of 'own resources' and increased the influence of the Parliament in the drawing-up of the Community annual budget. In addition, following the revision of the Treaty in 1975, the European Parliament acquired the power to reject the annual budget. Before examining the budgetary procedure and the role of the Community's institutions in particular, there are some points about the budget that need to be emphasised at the outset.

It should be stressed first that the impetus of EC-dynamics over the last ten years has been more through legislative action and court rulings than through making considerable funds available (see table 1). Despite the enormous amount of political dispute it has generated and despite a significant upward trend of its budget in the 1980 s, the net result is that the Community budget remains much smaller than national budgets. It represented only about 1.2 per cent of the Gross Domestic Product of the member states in 1997 and about 2.4 per cent of public expenditure in the member states. At the same time, however, the Community budget is bigger than the budgets of other international organisations. In contrast to them, its operating expenditure is far greater than its administrative expenditure ${ }^{8}$.

A second feature of the Community budget is that its revenue enjoys an important degree of autonomy. The budget is financed by means of revenue which are available to the Community by the member states, but which in legal terms belong to the Community. That is, no member can be unwilling to make these resources available to it. The system of own resources which was established by the Luxembourg Treaty of 1970, provided for three kinds of revenues: first, custom levies and duties on products imported from outside the Community and subject to Common Customs Tariff; second, agricultural levies on products imported from outside the EC (as a result of the 
GATT agreements, the agricultural levies have largely been replaced by custom duties since 1995); third, an amount calculated by reference to the VAT revenue collected in the member states, for example, resulting from the application of a uniform rate of 1,4 per cent on the VAT base determined in accordance with common rules (since 1988 this base cannot exceed 55 per cent of GNP of each country) 9 .

Table 1: Community budget by sector of activity (payments) for 1997

\begin{tabular}{|c|c|c|}
\hline & $\begin{array}{r}\text { Expenditure } \\
\text { (million } \\
\text { ECU's) } \\
\end{array}$ & $\begin{array}{r}\% \text { of Total } \\
\text { Budget }\end{array}$ \\
\hline $\begin{array}{l}\text { European Agricultural Guidance and Guarantee } \\
\text { Fund- Guarantee Section }\end{array}$ & 41305,0 & 50,1 \\
\hline $\begin{array}{l}\text { Structural actions, structural and cohesion } \\
\text { expenditure, financial mechanism other agricultural } \\
\text { and regional operations, transport and fishery }\end{array}$ & 26654,9 & 32,3 \\
\hline $\begin{array}{l}\text { Training, youth, culture, audio-visual media } \\
\text { information, the social dimension and employment }\end{array}$ & 780,0 & 0,9 \\
\hline $\begin{array}{l}\text { Energy, Euratom nuclear safeguards and } \\
\text { environment }\end{array}$ & 199,3 & 0,2 \\
\hline $\begin{array}{l}\text { Consumer protection, internal market, industry and } \\
\text { Trans-European networks }\end{array}$ & 731,0 & 0,9 \\
\hline Research and Technological Development & 3160,0 & 3,8 \\
\hline External action & 4796,5 & 5,8 \\
\hline Common foreign and security policy & 30,0 & 0,0 \\
\hline Repayments, guarantees, reserves & 445,0 & 0,5 \\
\hline $\begin{array}{l}\text { Administrative appropriations of the Commission } \\
\text { and other institutions }\end{array}$ & 4283,6 & 5,2 \\
\hline Total & 82365,6 & 100,0 \\
\hline Expenditure as a per cent (\%) of GDP & 1,17 & \\
\hline $\begin{array}{l}\text { Expenditure as a per cent of public expenditure in } \\
\text { Member States }\end{array}$ & 2,4 & \\
\hline Per capita expenditure (ECU) & 226,8 & \\
\hline
\end{tabular}

Source: European Commission, The Community Budget: The Facts in Figures, Luxembourg: Office for Official Publications, 1997.

A third notable feature of the Community budget is that "the revenue and expenditure shown in the budget shall be in balance". There is no such thing as Community debt and so none of the problems associated with the financing of national debts. Further, an overall ceiling on own resources, limits the growth of the revenue (and the expenditure) which is expressed in terms of the GNP of the member states. This 
ceiling is determined by the member states. Following the Brussels European Council of February 1988, the member states have decided to increase it from 1 per cent of Community's GDP in 1988 to 1,2 per cent of Community's GDP for payments up to 1992. A further increase in the overall ceiling on own resources was approved by the Edinburgh European Council of December 1992, leading to 1,27 per cent of GDP in the Community in 1999. A fourth source of revenue mentioned was established based on prosperity (e.g. GNP) of each member state. Its precise size is determined by the gap left between agreed expenditure and the volume of revenue generated by all other sources of revenue. We note that the last two resources, based on VAT and GNP, which are the most important, are not collected directly from the tax-payer.

As we can see, the Community budget is not concerned with social security issues that take up a very large fraction of national budgets. Its financial and policy impact continues to be very important on agriculture. It is in this sector that the transfer of powers to the $\mathrm{EC}$ has gone furthest since its establishment. The guarantee section of the European Agricultural Guidance and Guarantee Fund, which exists primarily to maintain farm incomes, constitutes fifty per cent of the Community budget in 1997.

The decisions to increase the volume of the budget at the Brussels European Council in 1988 and the Edinburgh European Council in 1992 was mainly linked to an increase in the redistributive function of the budget. Financial commitments to structural, regional and social expenditure take up the second largest proportion of the budget (thirty two per cent). Whether in the regional, social or agricultural sector, structural spending is designed to divert resources from richer to poorer countries and to help the poorer regions of the Community.

There are four Community structural funds. The aim of the European Regional Development Fund (ERDF), created in 1975, is to reduce disparities in the levels of development and prosperity in different countries or regions of the Community. The European Social Fund is primarily concerned with employment policy, in particular vocational training. There was a provision for its establishment in the Treaty of Rome in 1957, but it started to play a role only in 1971. The Guidance section of the Agricultural Fund aims primarily to support declining rural areas and was created in 1964. Since 1993, the Cohesion Fund is making financial contribution to environmental projects and Trans-European transport infrastructure networks in countries with a per capita gross national product which is less than $90 \%$ of the Community average, that is, Spain, Greece, Ireland and Portugal.

Public health is not mentioned as a specific budget item. In comparison to the other areas of Community policy, research was given priority in the European Councils mentioned above and its share accounts for almost 4 per cent of the budget in 1997. However, the co-ordination of biomedical and health research programme which started in 1978, is financed within the framework of the research policy and managed by the Directorate General for research (DGXII). The public health programmes such as "Europe against cancer" and "Europe against AIDS", are financed under the third budget sub-division, in particular under the rubric of "social dimension and employment". They were initiated in the middle 1980s and are managed by the Directorate General for social affairs (DG V). Chapter seven will review mainly the 
public health programmes and the biomedical and health research activities supported by the DGV and DGXII.

It is fair to say that data presented in this study do not cover Community spending on public health activities concerning developing or Eastern European countries. It is also fair to say that the scope of the Structural funds, in particular the European Regional Development Fund (ERDF) and the European Social Fund (ESF), was extended in 1993 to include investments in health. According to the first report of the Commission "on the integration of health protection requirements in Community policies", those investments concern hospital/health centre construction, renovation, the purchase of medical equipment (ERDF), and continuing training for health professionals (ESF) in Ireland, Greece, Portugal and Spain ${ }^{10}$.

In 1995, the Commission reported that the projects agreed with the responsible authorities in the Member States, amounted to around MECU 2,000 with a total Community contribution of MECU 1350. (The total ERDF budget for 5 years is 100 BECU). In Portugal the investment primarily concerned basic training for administrative health staff and retraining of medical staff for qualifications linked to new medical technologies. In Greece it covered the setting up of a national centre for emergencies and telemedincine services and the retraining of health staff. In Belgium, a particular project was established for the prevention of major diseases (cardiovascular, liver cirrhosis, pulmonary tuberculosis) in Hainaut. Finally, in the French overseas Department of Martinique an insertion project included measures to facilitate access of marginalised populations to health services.

\subsection{The adoption of the annual budget}

Most of the Community's financing and spending activities, including public health and research activities, are raised within the framework of the annual budget. The annual budget does not cover all of that activity, but it is with the drawing up and the adoption of annual budget that this analysis is now concerned. Article 203 of the Rome Treaty (as amended in 1970 and 1975) established a budgetary schedule, in five stages. The Commission submits a preliminary draft budget to the Council in stage one, which begins on 15 June each year. In stage two, the Council has 45 days to examine and amend this preliminary draft budget and adopt a 'draft budget', which it then forwards to the Parliament. From September to mid-October, the Parliament examines the draft budget and proposes modifications and amendments. In stage four which takes place from mid-October to mid-November, the Council conducts its "second reading" of the budget, and accepts or rejects the changes proposed by Parliament. Finally, in stage five, which takes place from mid-November to mid-December, the Parliament conducts its second reading, and the final budget is officially adopted upon receiving the signature of the President of the Parliament. According to Article 203(8), however, the Parliament,

"acting by a majority of its members and two-thirds of the votes cast, may, if there are important reasons, reject the draft budget and ask for a new draft to be submitted to it". 
Its willingness to reject the budget has been frequently raised since the first direct elections in 1979.

The 1970 Treaty also introduced the crucial distinction between compulsory (CE) and non-compulsory expenditure that defines ultimately the budgetary authority of the European Parliament. Compulsory expenditure can be defined broadly as all expenditure resulting from the treaty or acts adopted in accordance with the treaty. It is mainly concerned with the agricultural guarantee price support (which represents 51 per cent of the total in 1993). All other expenditure is non-compulsory (NCE). That is, expenditure, which can be defined as other than that resulting from the treaties or acts, adopted in accordance with the treaty. Regional, social, research and development, environment policy sectors and health policy are all 100 percent NCE.

Regarding the powers of the Parliament, the Parliament may propose modifications to items of compulsory expenditure in the Council's draft budget, but the decision of whether to accept these modifications is made by the Council in its second reading, and Parliament can not re-introduce its modifications at its second reading. Thus, for compulsory expenditure, the Council retains the last word. Moreover, the Parliament can propose amendments to non-compulsory expenditure, which are accepted or rejected by the Council in its second reading. The Parliament is not bound by the decisions of the Council and can reinstate these amendments in its second reading. For non-compulsory expenditure, therefore, Parliament has the last word. The Parliament is not, however, free to increase non-compulsory expenditures as much as it likes. Rather, the budgetary procedure ensures that the Commission fixes annually a maximum rate of increase in NCE. The Commission calculates this rate each financial year on the basis of a complex formula that takes into account growth in GNP, government spending and inflation in the member states. The Parliament can increase the total amount of NCE to a limit that is equal to one-half of this maximum rate.

According to Pollack, Parliament has since 1975 used its limited powers to increase non-compulsory spending, particularly in new and popular policies. Although the sums are relatively small, this shows that gradual, and Parliament led budgetary growth accounts for all of the growth of the Community budget for culture and consumer protection, and for varying levels of annual increase for environment, technology, education and regional policy. He also argues that this "Parliamentary creep" can be explained in terms of the partially supranational budgetary system of the Community, which gives the European Parliament limited powers to increase noncompulsory expenditure." The budgetary authority of the Parliament can thus be considered as important in relation to new policies such as health, where small financial increments might make a significant difference.

\section{Conclusions}

The Community has the power to use legal and financial instruments in the health field. We focused on the procedures to be followed by the Community institutions for adopting policy measures in the health field. We have been concerned first with the workings of the consultation procedure, which applies to the Treaty provisions relating 
to the social security rights of employed persons. That is to say that the Council adopts the legal measures (regulations) by a unanimous vote in the social security field and the Parliament is asked only for an opinion and on only one occasion.

We have then been concerned with the workings of the co-operation procedure introduced by the Single European Act and the co-decision procedure introduced by the Maastricht Treaty. They both altered the policy-making role as well as the relationships between the three policy making institutions, the Council, the Commission and the European Parliament.

The co-operation procedure covered and/or accelerated the adoption of legally binding acts such as directives related to medicines, environmental, consumer protection as well as occupational health and safety. Their adoption was part of the internal market programme. We will discuss in detail this harmonisation process and its implications for Community health regulation in chapter five.

The co-operation procedure changed first the voting rule of unanimity, by introducing qualified majority voting in the Council, for some ten articles relating mainly to the adoption of directives for the establishment of the internal market. The most important article covered by the co-operation procedure was article 100a which was also the most important legal instrument and indeed the primary source of task expansion into health legislation. Further, second readings and the co-operation procedure allowed the European Parliament together with the Commission to introduce amendments to Council legislation.

Today, the workings of the co- decision procedure introduced by the Maastricht Treaty cover the provisions relating to the internal market and, notably, article 100a. The new procedure was also introduced for articles relating to the adoption of action programmes in many policy areas and, notably, public health, consumer protection, environment and the general framework programme for research. In terms of democratic legitimacy, the co-decision procedure constitutes an improvement over the co-operation and certainly over the consultation procedure. In contrast to the act adopted by the latter procedures, which is an act of the Council, the act resulting from co-decision is adopted jointly by the European Parliament and the Council. It is a very complex procedure, but it increases the influence of the European Parliament over the establishment and the content of policies, which in the past has been very limited.

The power of the Community to use legal instruments may have increased. The power to use financial instruments is modest and relatively new. Most of the funds to support health action were raised during the last decade. In essence, the budget for health is subject to the overall limitations of the Community budget. Despite the enormous amount of political dispute it generated, and despite a significant upwards trend in the 1980 s, the Community budget remains much smaller than national budgets and represented about 2,4 of those budgets in 1997. An overall ceiling on own resources limits the revenue (and the expenditure), and this ceiling is determined by the member states. The Community budget is not concerned with social security. Further, public health is not even mentioned as a specific budget item. However, some public health programmes and research activities are supported by the Community budget. Chapter seven will review the development of these activities and the money involved. 
The European Parliament has since 1975 used its limited powers to increase noncompulsory spending, particularly in new policies, including consumer protection, environment and research and technology. Both the co-decision power and the budgetary authority of the European Parliament can thus be considered as important in relation to new policies such as health, where small financial increments might make a significant difference.

\section{Chapter Three References}

1. Mark A. Pollack, Creeping Competence: The Expanding Agenda of the European Community, Journal of Public Policy, No 14, 1994, pp 95 - 145.

2. N.Nugent, The Government and Politics of the European Community, London: Macmillan, 1989.

3. D. Guégen, A Practical Guide to the EC Labyrinth, Rennes: Editions Apogee, 1992.

4. See A. Dashwood, Community Legislative Procedures in the Era of the Treaty on European Union, European Law Revicw, Vol. 19, No 4, August 1994, p. 343-366; D. Earnshaw and D. Judge, From co-operation to co-decision, The European Parliament's path to legislative power, in J. Richardson (ed), European Union, Power and Policy Making, London and New York : Routledge 1996; Silvestro and C. Albani Liberali, La codecision a été un succès, Il faut aller de l' avant, Revue du Marché commun et de l'Union européenne, $\mathrm{n} \sqcup$ 406, mars 1997, p 166 - 169.

5. S. Boyron, Maastricht and the co-decision procedure: a success story, International and Comparative Law Quarterly, Vol 45, No. 2, April 1996, p 293 - 318.

6. N. Foster, Institutional and Jurisdictional Questions: The new Conciliation Committee under Article 189 b EC, European Law Review, Vol 19, No 2, April 1994, 185 - 194.

7. D. Curtin, The Constitutional Structure of the Union: A Europe of Bits and Pieces, in Common Market Law Review 30, 1993, p 17-69. (p 38).

8. For Community financing see M. Shackleton, Financing the European Community, Royal Institute of International Affairs, London: Pinter Publishers, 1990; For the budgetary procedure see S. Walder, The budgetary procedure of the European Community, Wien, Koln, Weimar: Bohlaus, 1992.

9. European Commission, The Community Budget: The Facts in Figures, Luxembourg, 1997.

10. Commission of the European Communities, Report from the Commission to the Council, the European Parliament and the Economic and Social Committee, on the integration of health protection requirements in Community policies, COM (95) 196 final.

11. Mark A. Pollack, Creeping Competence: The Expanding Agenda of the European Community, Journal of Public Policy, No 14, 1994, pp 95 - 145. 


\section{4}

Theories

on

Community

Policy-Making 


\section{Introduction}

The previous two chapters were devoted to an analysis of the institutional structure of the Community. This was based on the assumption that institutions matter for political decision-making in the Community on 'constitutional' as well as on substantive policy issues such as public health. We stressed from the outset that Treaties themselves play a key role through: their law-making functions; their definitions (or lack of) of authority and competence; their establishment of procedures; and the range of instruments involved in the implementation of common policies.

We discussed first the four main agents in Community policy-making: the Council of Ministers/European Council; the Commission; the European Parliament; and the European Court of Justice. We provided a first insight into the nature of the legal acts, particularly the binding acts in the health field such as regulations, directives and decisions, the procedures for their adoption and the share of responsibilities among the Community institutions. We also provided a first insight into the budgetary resources at the Community's disposal and their modest contribution in the health field.

But an institutional analysis of the Community leaves many questions unanswered. The Treaties, their institutional arrangements and the binding nature of the acts resulting from those arrangements have raised important questions since the establishment of the Community in the 1950s. What kind of political organisation is the Community? Is it a supranational body, an international regime or a new political structure? Which factors explain the institutional development of the Community? To what extent can it be considered as a polity of its own which must solve the classic problems of participation and representation? And to what extent can one distinguish the predominant patterns of Community policy-making from patterns observable in other political systems, national and international?

Various theoretical frameworks have been developed to answer such questions. Following Hix, these can be grouped in two major categories. The first has been named the "International Relations approach" and the second the "Comparative Politics approach"'. The International Relations approach is the more dominant of the two. It sees Community integration and policy-making within the context of relationships between nations. Within this approach considerable differences exist, and these differences will be briefly overviewed in this chapter. Attention will be paid to their main theoretical propositions, especially those of neofunctionalism and intergovernmentalism, of which we will critically assess the strengths and weaknesses. Finally, we will argue that both approaches should not be seen as competing but, instead, as complementing each other usefully in an analysis of Community policymaking on public health.

The Comparative Politics approach suggests that the Community should be seen as a political system of its own, with its own government, bureaucracy, political parties, system of representation, participation, and so on. The underlying assumption of this approach is, according to Hix, that, 
".politics in the $E U$ is not inherently different to the practice of government in any democratic system".

This assumption makes it possible to use theories of political science and sociology in the study of the Community structure and dynamics and to overcome the weaknesses of International Relations approaches. In the second part of this chapter we briefly discuss the Comparative Politics approach, including a brief overview of relevant critiques. The final question to be addressed is what lessons can we learn from the Comparative Politics approach for the study of Community policy-making on public health?

\section{The International Relations approach}

A common characteristic of theoretical frameworks belonging in the International Relations approach or paradigm is that they take territorially-based states as their unit of analysis. As Goldmann put it,

"if the state does not exist, neither would IR". 3

Regional integration, in this view, is the outcome of political interaction between nation-states. In this section we discuss two typical IR approaches: the neofunctionalist and the intergovernmentalist, which have often been depicted as competing and mutually exclusive.

\subsection{Neofunctionalism}

The purpose of neofunctionalism is to find an adequate explanation for the process of integration in the Community. One of the leading scholars in this approach is Haas, who defined political integration as,

"the process whereby political actors in several distinct national
settings are persuaded to shift their loyalties, expectations and
political activities towards a new centre, whose institutions possess or
demand jurisdiction over the pre-existing national states."

In his view, political integration is a complicated and long-term process that goes far beyond technical or functional co-operation between nation states. Such a co-operation is seen as the first step in the process of political integration.

Neofunctionalists claim that Monnet and Schuman, the founding fathers of the Community, adopted a neofunctionalist approach. It was their belief that a technical, sector-specific integration in Europe would eventually be followed by political integration. For Schuman, the pooling of resources in the European Coal and Steel Community was 'a first step in the federation of Europe. ${ }^{5}$ The emphasis on technical co-operation helped to avoid sharp ideological conflicts on the (partial) surrender of national sovereignty. Hoffmann, one of the leading theorists of the intergovernmentalist framework, called this the 'Monnet method' which he held for naive. 
The neofunctionalist approach has strong roots in pluralism. Policy-making in the Community is conceptualised as the outcome of political interaction between a multitude of players at several layers (political leaders, political parties, technical experts, interest groups e.g. employer and employee associations, industrial elite and the institutions of the Community). Within the Community, a complex network of domestic and transnational relationships has developed. In this 'cobweb' the institutions of the Community and particularly the Commission are allotted a key role as potential 'agents of change'. The Commission fulfils a stimulating role in the integration process. It is also expected to facilitate the transfer of elite loyalties to the European level and to develop acceptable compromises to overcome the political resistance of recalcitrant nation-states. The Commission also seeks political support among the elite groups who entertain positive expectations from the common market.

Neofunctionalists do not consider political integration in the Community as a linear process, characterised by comprehensive planning and the absence of miscalculations and political manipulation. Rather, they understand it as a step-by-step process that once began with the establishment of the European Coal and Steal Community from which then slowly the European Community evolved in an incremental way.According to Haas, the integration process has been characterised by,

"indirection, trial and error, miscalculation on the part of the actors desiring integration, manipulation of elite social forces on the part of small groups of pragmatic administrators and politicians in the setting of a vague but permissive public opinion. "Functionalism" and "incrementalism" are the key terms used in describing this theory".

Neofunctionalists assume that the integration process in the Community is driven forward by a growing convergence of interests on the part of significant economic groups and that, eventually, everybody can gain from it. Unlike intergovernmentalists, they conceptualise regional integration as a positive-sum game. In their view, national governments are increasingly unable to cope effectively with the challenges emerging from the internationalisation of national economies. Giving up some sovereignty and transferring some parts of the national policy-making competence to a supranational level is an inevitable and appropriate answer to the ever-growing interdependencies in the economic world.

In this respect, it is also important to point out that the policy framework of Community integration was guided by a free-market ideology. All treaties stressed the virtues of a free competitive economy and held that increases in living standards could only be achieved as a result of more effective competition rather than direct planning.

How, then, does the integration process proceed? Haas's concept of spillover can be regarded as a cornerstone in his neofunctionalist framework. Spillovers give the integration process a kind of momentum of its own. There are two basic types of spillovers. Functional, or sectoral, spill-over refers to the situation in which a given action, related to a specific goal, creates a situation in which the original goal can only be assured by taking further actions, which in turn create a further condition and a need for more action, and so forth. ${ }^{7}$ In this view, when Member States agreed (in the treaties) to create a free competitive market, they inherited the political problem of 
compensating for market failures, supervising rules and resolving conflicts. Cooperation in the common market triggered (spillover) co-operation in other sectors and would eventually lead to the development of common fiscal, labour and welfare measures. This is the logic of functional spillover.

Political spillover consists of a convergence of the expectations and interests of national elites in response to the activities of the supranational institutions. It may result in a transfer of loyalties (authority-legitimacy transfer), or, at a minimum, in a transformation of political activities of national elites in favour of new supranational policies. Haas sees political spillover as a consequence of functional spillover through which Community policy-making increasingly becomes a natural focus of competing economic and social interests. The transfer of political loyalties of interest groups will accompany the gradual shift of the centre of economic policy-making towards Brussels. Thus, the articulation of demands towards the Community reinforces the authority of the system as a whole. As a result neofunctionalism predicts the movement from negative integration (the removal of barriers to trade) to positive integration (the pro-active co-ordination of common policies in order to fulfil economic and welfare objectives).

In Haas's view the gradual process of economic and political integration makes the Community a new and singular system, neither international nor national but supranational. Governmental authorities involved in the Community are closer to the archetype of federation than any past international organisation, but are not yet identical with it.

Neofunctionalism has been subject to much criticism. ${ }^{8}$ First of all, its empirical validity has been questioned. The development of regional integration in the Community has been more problematic and has proceeded with more up and downs that the neofunctionalists tend to assume. Dramatic political actors may upset the rhythm and predictability of the policy-making process.

The emphasis upon the institutional logic of functional spillover presents another criticism. Neofunctionalists implicitly assume a distinction between political and technical issues. The 'automaticity' of functional spillover is explained by the technicality of many issues. National experts co-operate with the experts of the Community institutions to solve these issues. Successful incrementalism presupposes the existence of a condition whereby political parties and interest groups avoid sharp ideological conflict and technocrats play a leading and indispensable role in the integration process. However, the practice of Community policy-making is often quite different. Issues, which at first sight may look quite technical, often turn out as very political and may even be defined by their governments as a national priority. In other words, the distinction between political and technical issues is highly misleading. Due to their technocratic model of policy-making neofunctionalists tend to neglect the political dimension in Community policy-making.

The pluralistic character of the policy-making process in the Community has been put forward as a third weakness of neofunctionalism. Neofunctionalists assume that interest organisations such as trade unions, employer and consumer associations enjoy equal access to the Community political process. But the influence of interest groups 
upon Community policy-making is contingent upon many factors, such as the strategic position and political status of these groups within their society. ${ }^{9}$ Whereas some (transnational) groups have excellent contacts with the Commission and seem rather powerful, others lack such contacts and are less influential. Another aspect of this critique is that the concept of equal access is a myth even within the bureaucratic machinery of the Community. The power balance between the Directorates General under the Commission is even less than the analysts would assume.

A fourth weakness is that neofunctionalists tend to overestimate the strategic role of the Community institutions, particularly the Commission, which has often been depicted as the core in the 'cobweb' of the Community network of relations. Advocates of the intergovernmentalist framework postulate that neofunctionalists dramatically underestimate the role of national governments in the Community. The Commission's room for manoeuvring is limited by national governments, which often resist giving up their autonomy in policy-making. They interpret the formal incorporation of the European Council in the institutional structure of the Community 1974 as an evidence of the preponderant role of national governments in Community policy-making. The Commission's role is also undermined by the fragmented structure of internal policy-making arenas. The interests and policy objectives of the participating Directorates General are often highly conflicting. The development of active interventionist policies to satisfy manifest and latent interests is also hindered by the lack of sufficient fiscal and institutional resources at the disposal of the Community institutions. Although the Community budget has grown, it still represents a tiny fraction of national budgets: its revenue is made available by the Member States and is collected by national officials. Neofunctionalism did not adequately address the problem of democratic control of the functionally integrated tasks. Issues of democratic legitimacy and authority still remain important and controversial issues. Last but not least, task expansion did not avoid sharp ideological conflict between neoliberal and social protectionist coalitions; and between Socialists, Christian Democrats and "free market" Conservatives.

The stagnation of the Community integration process has challenged the writings of the neofunctionalist scholars in the late 1960s. Haas himself analysed the shortcomings of his regional integration theory in his later work. In particular, he questioned the expansive logic of sectoral integration and the central role of the Commission in policy processes. In his view the incrementalist rationality posited by neofunctionalist theory did not, in fact, characterise the behaviour of Community Member States. Instead, he suggested States behave in terms of a rationality he called 'fragmented issue-linkage'. Under conditions of uncertainty and turbulence therein, the functional links among sectors are unclear, and linkages are more likely to be contrived than deliberate. Successful extension of integration to new sectors therefore, might well take place, not because of functional spillover from the common market, but in response to 'imperatives' of an external nature not captured in regional integration theories. ${ }^{10}$

Neofunctionalism has witnessed a revival in recent years which stems from a hope of using this theory to explain the new momentum of Community integration - the development from the negative integration of the Single European Act in the eighties 
to the positive integration of the Treaty on European Union in the nineties." Nevertheless, many of the original critiques concerning the limitations of the functionalistic logic of spillover to explain the development and growth of Community politics still hold. Yet, the fundamental reliance on the voluntary actions of functional interest groups and political parties to stimulate spillover and indeed Community task expansion into social policy, social security and health care has been eroded.

\subsection{The intergovernmental approach}

Scholars using the intergovernmental (or realist) approach conceptualise Nation-States as the most important agent in international politics. The nation-state is seen as a cohesive and organised entity that aims at defending its national interests in an adversarial international world. States are motivated by their desire to maintain and enhance their power relative to that of other States. Of course, States differ as to their capability to preserve their national interest, depending on their size, wealth, power, form, and other factors. ${ }^{12}$

From an intergovernmental perspective the Community represents a gathering of sovereign States. It has an intergovernmental or international rather than a supranational structure. The accumulation of power in the newly created 'supranational' institutions is limited by the fundamental resistance of the national governments to delegate much of their autonomy in policy-making to the Community institutions. According to Hoffmann, the Community was historically supranational in intention but intergovernmental in practice. ${ }^{13}$

Intergovernmentalists also reject the cobweb model of the Community of the neofunctionalists and replace it by a billiard ball model. In this model nation States are seen as billiard balls and their interactions as the bumping of these balls. Intergovernmentalists also develop a different view of sovereignty and 'the national interest' than do neofunctonalists. Intergovernmentalists regard sovereignty as a crucial national value which national governments will never consider negotiable in an international context. By contrast, neofunctionalists take a more functional view of sovereignty. They stress what could be called the sovereignty-capacity equation. As nations are increasingly caught in a web of international economic relations, a purely sovereign approach is no longer appropriate and would inevitably fail. In the neofunctionalist view, sovereignty is not indivisible, but linked to the legitimate and effective performance of tasks. Intergovernmentalists also postulate that 'the national interest' exists and that national governments are able to define it. In their view, the national interest is not subject to domestic claims and counter-claims. Neofunctionalists reject such a monolithic view of the national interest and argue, in the pluralist tradition, that interest groups usually articulate rivalling definitions of the national interest in the transnational policy-making arena of the Community. Furthermore, intergovernmentalists argue that the concept of a national interest is eroded by the growing emphasis of transnationally-operating sectional groups upon common or transnational interests. ${ }^{14}$

In the intergovermentalist perspective the prevailing image of politics and policymaking in the Community is one of lengthy and hard bargaining processes in the 
intergovernmental fora of the Community, that is in the Council of Ministers and, above all, the European Council. These institutions are depicted as evidence of the fact that national governments constrain the growth of the Community's supranational institutions and policy scope. The intergovernmentalist image of the Community also reflects the legacy of certain political leaders, most notably De Gaulle and Thatcher, both of whom lost no opportunity to assert the primacy of the nation-state in Europe. ${ }^{15}$ The creation of the Committee of Permanent Representatives (COREPER) is interpreted as another evidence of the growing domination of Community policymaking by national governments.

The intergovernmentalist view of the Community was formulated by Hoffmann. He argued that government willingness or refusal to go along with functional co-operation while resisting co-operation in politically sensitive areas (such as foreign policy, defence and macroeconomic policy) constituted the main reason for the failure of the neofunctionalists to predict accurately the outcome of European integration. He suggested a distinction between 'high' and 'low' politics. Issues in the national arena could be categorised as 'high' if they involved essential matters of state security, independence, provision of vital resources, indeed anything that touched on the survival of the state itself. By contrast, 'low' politics related to technical or less controversial issues such as economic or administrative matters. Hoffmann postulated that national governments could not be expected to concede a role to international institutions in matters of 'high' politics. They may be prepared to collaborate in the domain of 'low' politics to the extent where co-operation in these areas could be justified as a pragmatic exercise. ${ }^{16}$

Whereas neofunctionalists see Community integration as a positive-sum game, intergovernmentalists take a different view. Hoffmann suggests that it is a zero-sum game in which governments are inclined to define their position in rigid terms,

"on a vital issue, losses are not compensated by gains on other (and especially not on other less vital) issues(...). Ambiguity lures and lulls the national consciousness into integration as long as the benefits are high, the costs low, the expectations considerable. Ambiguity may arouse and stiffen national consciousness into nationalism if the benefits are slow, the losses high, the hopes dashed or deferred. Functional integration's gamble could be won only if the method had sufficient potency to promise a permanent excess of gains over losses, and of hopes over frustrations. Theoretically, this may be true of economic integration. It is not true of political integration" "I7.

Hoffmann also casted profound doubts about the application of a Federalist model to the 'making of Europe'.

"Not only is there no general will of a European people because there is as of now no European people, but the institutions that could gradually (and theoretically) shape the separate nations into one people are not the most likely to do so. For the domestic problems of Europe are matters for technical decisions by civil servants and ministers rather than for general wills and assemblies (a general will 
to prosperity is not very operational). The external problems of Europe are matters for executives and diplomats. As for the common organs set up by the national governments, they are both condemned to operate in the fog maintained around them by governments and slapped down if they try to dispel the fog and reach the people themselves. ${ }^{\prime \prime}$

The intergovernmental view of the Community integration process has not gone unchallenged in both theory and practice. For example, national governments have taken important political decisions with regard to market integration and the monetary union. These decisions can be considered a major institutional and policy innovation in recent years. The Community moved away from neatly defined and relatively selfcontained sectors into the uncertain world of macro-economic policies and industrial adjustment.

The monolithic view of the notion of the national interest is another aspect of critique. Detailed case studies of Community policy-making showed that the definition of the national interest often diverges and is heavily shaped by the interests of the sectional groups participating in the policy-making process. What emerges from the case-studies is that a government's role in integration processes often appears much less consistently orchestrated than the Intergovernmentalists tend to assume. Webb has spelt out, that intergovernmentalists neglect what is called the intragovernmental and transgovernmental dimension in the Community policy-making process. The intragovernmental dimension refers to the domestic co-ordination of a government's participation in the policy-making process. Given the tremendous complexity of the policy issues and the broad variety of interests at stake, it is a far from easy task to define the national interest and to keep every participant upon the same consistent line. The transgovernmental dimension calls attention to the multiple contacts between governments at several layers of decision-making.

Intergovernmentalists have also been criticised for their distinction between 'high' and 'low' politics. Such a distinction is considered artificial and inappropriate since 'low' political issues may easily turn into 'high' political issues. Furthermore, the intergovernmentalist interpretation of the integration as a zero-sum game has been rejected as too simple. When common advantages come into play, the zero-sum condition does not apply.19 An important driving force behind the recent developments in European integration was the fact that Member States had decided that a supranational approach of various common problems best services the national objectives and interests.

Detailed case studies of Community policy-making suggest a different picture of political decision-making than the intergovernmentalists put forward. Intergovernmentalists emphasise the prominent role of government leaders in Community decision-making fora. But much of the policy-making work is done somewhere in the Brussels machinery where the bureaucrats of the Community meet with national and other experts. These persons have often known each other for many years and have seen each other on many occasions. They may see it as their common task and in their interest to work on acceptable compromises. 
Despite these criticisms, the intergovernmental approach helps to explain why the Community integration process often proceeds slowly and stagnates upon national interests expressed by government leaders and their representatives in the decisionmaking fora of the Community. The neofunctionalist assumption of an economicpolitical continuum is rightly questioned. Limited sectoral co-operation will not automatically lead, through the mechanism of spillovers, to political co-operation. Intergovernmentalism also provides a better theoretical framework for explaining the evolution of the Council-Commission relationship in a direction, which has been more to the advantage of the Council of Ministers. The Luxembourg compromise ending France's six-months of withdrawal from the Council of Ministers by agreeing that a state's 'very important' interests would be protected against an adverse majority vote in the Council, can probably explained as the most dramatic evidence of the preponderant role of nation sates in the Community integration process.

More recently, some scholars have attempted to refine the intergovernmentalist argument by focusing on the new political developments in European integration like the Single European Act or the Treaty on European Union. Moravcsik, for example, has formulated a liberal intergovernmentalist view of the Community, which combines a liberal theory of national preference formation with an intergovernmentalist theory of international negotiation ${ }^{19}$. In this view, member state governments remain the crucial actors in European integration. The interests or preferences of these actors are products of liberal interest-group politics within each member state. Member governments then bring these preferences into intergovernmental bargains, which in turn reflect the preferences and the bargaining power of the various member governments. In this sense, Moravcsik abandons the notion of the 'vital' national interests and adds an explicit theory of bargaining which addresses (a) the sources of, and differences in bargaining power among member governments, which are explained in terms of the intensity of preferences, and (b) the conditions under which member governments might be willing to pool or delegate sovereignty. ${ }^{20}$

\subsection{Other approaches}

It would be too simple to assume that the neofunctionalist and the intergovernmentalist approach to the study of Community integration and policy-making are the only analytical frameworks using an International Relations perspective. Another framework in this perspective, which has drawn some attention, is the interdependence approach. $^{21}$ Interdependence analysts ${ }^{22}$ do not offer a theory of Community integration, but, more generally, centre their analysis upon the problem of political management of economic exchanges in Western Europe. In their view, national boundaries loose their importance as the globalisation of economic and security issues increase. Growing interdependencies between nations are seen as the primary source of erosion of national authority.

By their strong focus upon the underlying structural forces, interdependence analysts do not develop an agent-biased theory of Community integration as do the neofunctionalists and intergovernmentalists with their emphasis upon the role of national governments and other groups in the integration process. In contrast to 
neofunctionalists, interdependence analysts do not see the Community institutions as effective agencies since they lack sufficient political and economic instruments. The prevailing image is one of an increasingly fragmented and uncontrollable political process. For that reason, interdependence analysts also prefer to avoid the concept of integration as it is held as misleading, and replace it by the more neutral concept of interdependence.

Interdependence can be classified as a structural approach to the study of the Community. Another example of the structuralist family is the Marxist interpretation of the Community in which the integration of Europe is seen as a response to a new historical phase in the development of capitalism. The concept of disorganised capitalism is used to denote a general transformation in the mode of production and exchange. Major global tendencies include, among other things, the dominance of footloose multinational capital, transfers of capital within multinational corporations, and the movement from secondary to tertiary production ${ }^{23}$. In the course of this transformation process, the Community is envisaged as a means of the capitalist state to cope with the modified forms of competition. Indeed, the single market programme would be impossible without the consolidation of a system of States that tries to introduce capitalist regulation. ${ }^{24}$

The concept of capitalist regulation denotes the need for an analysis that encompasses the economic system as a whole. In this perspective, Community regulation cannot be limited to a mere analysis of its functional purpose or instrumental role. Rather, it acquires its full meaning through the introduction of a new set of social rules that govern the production and distribution of the means of existence of human beings organised in social groups. The interaction between the transformation in the conditions of existence of the wage- earning class and the change in forms of competition, is at the heart of the problems of capitalist regulation and Community regulation in particular. This contradictory process does not take place without transforming the structure of the Member States themselves. It is also embodied in the creation of new structures that take the form of organised Community institutions. Consequently, Marxist theories explicitly introduce a political dimension of conflict to Community politics, that is the class conflict inherent in capitalism. In this view, the Community represents essentially a neoliberal order of capitalist regulation.

\subsection{Towards a synthesis}

In this section we discussed different theoretical approaches to the scientific study of the Community with a special emphasis upon the neofunctionalist and the intergovernmental approach. Both approaches have in common a focus upon the process of Community integration. Whilst neofunctionalists are rather optimistic about the evolution of the integration process, intergovernmentalists are more sceptical. Intergovernmentalists point much more vehemently to the political limitations to Community integration than the neofunctionalists.

The neo-functionalist approach sees the Community as a kind of supranational organisation. It is the result of an incremental integration process in which a pluriform set of actors (ranging from the political leaders of the Member States, and the Com- 
mission and the European Parliament, to national and transnational interest groups, political parties and other political and social elites) always play a prominent role. Neofuctionalism, however, represents the first theoretical effort to explain and predict Community task expansion, that is, the movement from the removal of barriers to trade to the pro-active co-ordination of common policies in order to fulfil economic and welfare objectives. Essential to this concept has been the problem inherent in the institutional logic of the common market: since the member governments decided to create a common market, they would have to face the political problem of regulating that market, compensating for market failures, supervising rules, resolving conflict, and fine-tuning. In this perspective, a central role was envisaged for the Commission in the policy-making process.

The intergovernmentalist approach on the other hand emphasises the dominant role of the Member States in the integration process. The Community is conceptualised as an international rather than a supranational entity in which the evolution of regional integration is determined by the way Member States define their national interests and appreciate how a community approach would contribute to their national interests. Integration proceeds to the extent that it is in the interest of the Member States and helps them to protect or enhance their power position relative to others. In this perspective, the governments of the Member States and indeed the Council of Ministers dominate policy-making. Early realist interpretations of the EC did not only pay attention to the central role of governments in Community integration and policymaking, they also helped to focus attention on the significance of the differences in the national circumstances, cultural experiences and institutional practices of the countries that are engaged to integrate.

Following Cameron, we believe that we should not choose either one of these approaches. Neither functionalism nor intergovernmentalism provides an adequate explanation of Community integration and policy-making. In his analysis of the establishment of the monetary union ('the 1992 initiative') he concludes,

\section{"that both neofunctionalism and realism - taken together rather than as alternative approaches - are useful for, and indeed necessary to, an understanding of the 1992 initiative.}

This eclectic approach to the Community will also be practised in our analysis of the development of a public health policy. In the next chapter, we will use the neofunctionalist theory to study Community task expansion in health regulation. The development of health legislation across various policy fields will be explained largely in terms of the functional linkages between these fields and the common market.

The intergovernmentalist perspective is also helpful to understand Community policymaking on public health. This perspective is particularly helpful in the analysis of the political limitations to a common approach to public health. In chapter 1 we saw, for example, that the Community is explicitly denied a formal competence in harmonising national social security systems. More generally, it was stated that according to Article 129 of the Maastricht Treaty, the formal competencies of the Community are still rather limited, although they were somewhat enhanced in the Amsterdam Treaty. These limited competencies suggest that national governments are still unwilling to 
give up much of their sovereignty in the provision and organisation of health (care) services in favour of a common European public health policy. In the next chapters we will see other evidence of the political constraints of such a policy.

The structural approach to Community integration and policy-making is also helpful for the study of public health in the Community. This approach particularly points to the political left-right dimension of conflict involved in developing a European policy in the health sector. In this perspective, the Community is envisaged as a means of the capitalist state to cope with global transformation in the mode of production, exchange and the modified forms of competition. In their view, thus, neither the single market programme nor the economic and monetary union would be possible without the consolidation of a system of States that try to introduce new forms of capitalist regulation. Therefore, a central role and indeed responsibility is envisaged for national governments in the integration as well as the Community policy-making process. Nevertheless, the point here is to emphasise that new forms of market regulation or monetary arrangements have implications for the welfare state, social security and health care arrangements. In chapter six, we will highlight the heated discussions about the implications of the new rules governing market and exchange for social security and health care.

\section{The Comparative Politics Approach}

The Comparative Politics approach does not conceptualise the Community as a process of interactions between Nation-States but, rather, as a polity or political system of its own. The comparative approach is a method of analysis, based upon the underlying assumption that the Community represents a new level of governance. Thus it is a systematic comparison of the Community with other political entities, in particular the nation state and is not a comparison of apples with oranges.

This perspective opens the way to the use of political concepts and principles derived from the study of the nation-state in the study of the Community system and its policymaking. The expectation is that a comparative analysis may greatly contribute to our understanding of Community integration and policy-making and may yield interesting new insights into the structure and dynamics of the Community and its structural problems.

Expectations are high. In the words of Sbragia,

"thinking about the Community comparatively will prove to be more fruitful analytically than simply describing the Community as "unique" and consequently analysing it exclusively on its own terms. ${ }^{226}$

In a similar way Hix argues,

"that the comparative politics paradigms often produce more profitable insights for the study of EC 'politics'". ${ }^{27}$ 
According to Hix, the comparative politics approach is still in its infancy. Yet, several examples of it can be found in the literature. We shall briefly discuss here what calls Hix pluralist approaches, institutional approaches, and sociological approaches.

\subsection{Pluralist approaches}

Pluralist approaches focus upon the process of articulation and mediation of interest groups in a political system. Governance is not a unilateral activity of a government. Rather, pressures articulated by interest groups in the political arena shape it. Pluralist scholars analyse Community policy-making as the outcome of political interactions between a plurality of competing groups all defending or promoting their sectional interests in the political arena of the Community.

Pluralism presents in fact a category of theoretical approaches. A single pluralist theory does not exist. In its most pure, American-style, form interest groups should be multiple, voluntary, competitive, non-hierarchically ordered, self-determined, not monopolistic, and not supported by the government. They all should have equal access to the decision-making bodies, which operate as more or less neutral arbiters between conflicting interests. $^{28}$ The neocorporatist and European variant of pluralism postulates the existence of intimate relationships between the government and interest groups. The government parties and the 'co-opted' peak organisations of business and labour, which operate as monopolistic articulators of group interests, control policymaking. They are often given a formal role in the decision-making process. Emphasis is put upon consensus-building and collective interests rather than upon political conflict and group interests. ${ }^{29}$

The basic questions are, then, to what extent Community policy-making can be accurately analysed in terms of pluralism, and what we can learn from this perspective? According to some scholars, policy-making in the Community is more open to interest groups than in the neocorporatist-type political system. The 'open' and fragmented structure of Community policy-making also helps to explain why, since the mid-eighties, interest groups have rapidly expanded their lobbying activities in Brussels and why the number of interest groups has dramatically grown. In each specific area of Community activity, policy-making is controlled, to a large extent, by special interest coalitions. Yet, interest mediation in the Community is far away from the pluralist ideal type of policy-making. The concept of equal access of interest groups to the policy-making machinery in Brussels is a myth. Whereas some groups appear very influential, particularly in the agricultural and economic sector, other groups, for instance consumer and environment groups, are still much less influential.

Furthermore, decision-makers in the Community do not operate as neutral arbiters, but rather as active agents proactively taking account of opposing interests and seeking political support for their policy ideas. Parts of Community policy-making even resemble the neocorporatist way of policy-making. For example, in the field of social policy the Commission has deliberately sought to establish standing relationships with the transnational representatives of the employers and employees. We refer here to the special status of the UNICE and the ETUC in the development of legislation under the Social Charter. 


\subsection{Institutional approaches}

Scholars following an institutional approach in the study of polities place institutional structures and procedures at the heart of their analysis. They are thought to reflect the basic principles of the polity and to cover critical issues of governance and legitimacy, such as: the election of representatives in legislative assemblies; the allocation of power among the legislative, the executive and the judicial powers; and the issues of political authority and autonomy. The identification of the institutional rules and structures that govern the making of political decisions is considered of fundamental importance to the interpretation of policy outcomes.

An example of an institutionalist approach is Sbragia's analysis of the Community ${ }^{30}$. In his view the Community is only a 'partial polity', due to the key role of national governments in the Community, the strength of the territorial dimension and the democratic deficit. He concludes his analysis by asserting that the Community most resembles the German model of federalism.

Sbragia emphasises that the Community is a creature of treaties rather than a constitution. The evolution of the Community heavily depends on how national governments view the Community and their role in it. In negotiating treaties national governments determine the timing and shape of institution building in the Community. National governments also decide upon the competencies of the Community institutions and upon which competencies they want to keep in their own hands. In his view, the process of creating institutions by treaty maximises the power of the executive within all national governments concerned.

Another key issue in Sbragia's analysis concerns the territorial dimension of the Community. For instance, most individuals in the Community speak their own national language and, thus, cannot communicate across territory. Another cultural dimension of territory is that a common European identity does not exist. He stresses that the conflict between the representation of territory and the representation of voters remains a crucial element in the debate over the future appropriate decision-making role of national governments in the Community.

Finally, the Community suffers from a democratic deficit. Although the European Parliament has strengthened its position in Community policy-making in the Single European Act and the Treaty on the European Union (Maastricht Treaty), it still lacks, by comparative standards, power to intervene and exercise control of the executive. According to Sbragia, 'the Parliament is too weak to provide the kind of democratic accountability conventionally implied by the term democracy' ${ }^{31}$.

What kind of political system, then, is the Community? Sbragia here suggests that the insistence in the Community on the representation of territorially defined governments makes the German rather than Anglo-American model of federalism a possible useful guide to thinking about future institutional arrangements in the Community. This applies to the critical questions of both the allocation of power among institutions and its democratic legitimacy, and the exercise of public authority. In the German federal model, Länder governments are not represented but are participants and decisionmakers in national policy-making. Furthermore, the responsibilities are not divided 
between the federation and the States by policy areas, but by functions in the policymaking process. It is a system of mixed competencies. Policy tasks are not simply allocated to a single constituent part of the political system but shared by the Länder and the federal government in Bonn. The German model allows one to think about the exercise of public authority without imposing a centre-periphery division model on such an exercise. It is thus in this regard that the German federalism is most comparable to the Community.

Hix suggests Lijphart's theory of a consociational democracy ${ }^{32}$ as another example of the institutionalist study of the Community ${ }^{33}$. Lijphart proposed his theory to explain how severely divided (segmented) societies such as the Netherlands, Belgium, Austria and Switzerland, can remain stable democratic regimes as a result of behaviour and rules that produce 'elite accommodation'. This last term denotes the settlement of divisive issues and conflicts in a largely non consensual context. The key element of a consociational democracy is that the leaders of the self-contained blocks or 'pillars' must be particularly convinced of the desirability of preserving the system. So there is a minimum of consensus in the system. The 'cartel' of political leaders of all significant segments, therefore, co-operates to govern the country. Political leaders are willing and capable of bridging the gaps between the mutually isolated blocs. Another essential feature of a consociational democracy is that the mutual veto or 'concurrent majority' rule protects vital minority interests. Furthermore, proportionality is used as the principle standard of political representation, civil service appointments, and allocation of public funds. Finally, each 'pillar' is allotted a high degree of autonomy to run its own affairs.

The Community displays several features of consociational democracy. First of all, there is a minimum consensus among the political leaders in the Community, that the existing Community system should be maintained and not be allowed to disintegrate. Secondly, the Community can be considered a 'territorially' pillarised system because individual interaction and loyalty is primarily focused within the Nation States. Thirdly, there is a 'cartel of elites' at European level because of the elite/governmental nature of decision making in the Community and because of the rules to ensure elite accommodation. Fourthly, the desire of governments in the Community to protect their national sovereignty is the equivalent of segmental autonomy within territorially pillarised federal systems. Fifthly, proportionality is ensured in the system of representation in the Council of Ministers and the European Parliament, in the allocation of jobs in the institutions' administrations, and in the allocation of Community resources. Sixthly, the Luxembourg Compromise guarantees the mutual veto in the Community, which allows a member state to exercise veto in the case of a threat to a vital national interest.

Also, Taylor considers what he calls 'consociationalism' as more relevant than federalism for explaining the process of regional integration and central decision-making in the Community ${ }^{34}$. He points to the symbiotic character of Community integration in the 1980s and early 1990s. The state and the international organisation appear capable of being mutually reinforcing. The theory permits an understanding of the effects of functional co-operation as positive, in the sense that links are strengthened and political attitudes towards the Community modified. But consociationalism also 
permits an understanding of its negative effects. Strengthening regional functional systems may help to sharpen rather than soften cleavages in the existing society of nations. Comprehensive international arrangements may challenge rather than reinforce the process of developing a transnational socio-psychological community. Integration itself, therefore, produces pressures, which tend to reinforce segmental autonomy. Political leaders of all significant segments (the members of the Council of Ministers and the European Council) are likely to be faced with a dilemma: they will have an interest in increasing the share obtained by their own segment, whilst at the same time presenting themselves as leaders and agents of a distinct clearly defined community.

Taylor points to two ways in which the special interests of the elites may be stressed in the process of regional integration. Members of the cartel of elites may make agreements together for their own purposes, even if these conflict with those of the segments which they nominally serve. They may also seek to use the context of the common arrangements to promote changes, which suit better the interests of their key supporters in their particular segments, so that their power within is consolidated. In contrast to a federalist integration process where the idea of a central government which identifies and acts upon a common interest is relatively strong, consociationalism reinforces the search for the lowest common denominator. In sum, whereas federalism and other integration theories expect elites to act in the interests of the greater number in the longer term, consociationalism highlights the ways in which existing political elites might pursue international integration for their own selfish reasons at the cost of community solidarity. Indeed, it shows how the Community can develop as a framework for co-operative activity without undermining the desire of governments to protect their sovereignty.

As a final example of an institutionalist approach to the study the Community, Scharpf $^{35}$ focuses on the problems of the democratic deficit at the Community level, that is the lack of Parliamentary responsibility in the Community system combined with the Council as the main decision-making body over important matters including economics, politics, ecology and technology. He also points to the lack of political control of the Commission, which plays an important role in agenda setting. In addition, he refers to the lack of a European collective identity. In sum, after forty years of European integration, the Community is in his view far away from constituting a European public sphere and there is nothing like a Europe-wide discourse of the key issues of the European agenda. The elections for the European Parliament do not provide the forum for a European electoral campaign. There are few who know to what extent the balance between the parliamentary groups will be modified after the elections. In addition, there is nothing like a European press or a European media. Citizens know little about each other's affairs and are far from feeling 'comme de compagnons de destin et comme une seule unite d'action. ${ }^{36}$ This should not be seen only as the result of the differences in economic development between the Member States, but it should most importantly be linked with the ethnic, linguistic, cultural and institutional heterogeneity of the European nations and regions. Scharpf, therefore, does not see either the German or the Anglo-American model of federalism as a solution of the current legitimacy gap. Even if the President of the Commission will be 
politically elected and the European Parliament substantially increase its powers, he sees the European political order as remaining carefully restricted to issues that transcend national frontiers. To avoid the trap of delegitimation, he suggests a dual federalism, a kind of the Swiss segmented communalisation, with clear-cut political powers and guarantees of democratic responsibility (according to competencies) for both the central institutions of the Community and for the national and regional institutions.

\subsection{Sociological approaches}

Hix also discusses what he calls sociological approaches to the study of the Community. He refers in particular to Almond's influential political sociology theory, which laid the foundations for the application of certain sociological and anthropological concepts to the comparative study of political systems during the $1960 \mathrm{~s}$ and $1970 \mathrm{~s}^{37}$. The study of the interrelationship between social structures and political institutions has been central to the general conceptual and theoretical concerns of political sociologists interested in comparing political systems ${ }^{38}$. Although such approaches can shed an interesting light upon the Community, they are still rare.

In order to illustrate the 'added value' of sociology to the study of the Community, Hix addresses the issue of nation building, a central theme in the work of Lipset and Rokkan $^{39}$. Building upon Parsons' systems theory of politics, these authors propose a model of nation building according to which each political system must find an adequate solution to two fundamental problems or cleavages in society. The first problem he names the centre-periphery problem. A classic version of this problem is the Church versus the State problem, which nations have solved quite differently. The industrial revolution gave rise to land versus urban, and middle-class versus workingclass conflicts. Within the context of the Community, the centre-periphery problem refers to the conflict between integration and national sovereignty. The second problem is the basic left-right problem: the (re)distribution of vital resources in society and the balancing of economic interests with other interests, such as the interests of the working class, the environment, and the consumers. Within the context of the Community, the left-right dimension in Community policy-making focuses the analysis upon the balance between the free market and Community intervention. Hix observes an increasing politicisation in the Community on socio-economic and other substantive policy issues, which is not properly understood when only studying them in terms of more or less supranational integration. Differing opinions about these issues may not only be shaped by national interests of protecting national sovereignty, but also by political ideologies cross-cutting national boundaries. In his view, then, the study of Community policy-making in terms of a continuum ranging from supranational integration at one extreme to national interdependence at the other is incomplete. Such an analysis must be made more complete by introducing a second continuum ranging from a left stance toward substance policy issues to a right stance. 


\subsection{Conclusion: The value of comparison}

From the perspective of a Comparative approach, we first considered the recent attempts to understand both transnational interest group formation and the nature of interest intermediation in the political arena of the Community. A primary question here familiar from the studies of national interest group systems is to what extent does interest formation fit American style pluralism and its European neocorporatist variant? The institutionalist framework, on the other hand, focuses attention upon institutional structures and procedures and analyses how the classic political questions of participation and representation have been solved (or not). One of the primary questions here refers to the weakness of the European Parliament and the so-called democratic deficit in the Community.

Another issue is to what extent the Community may be conceived as a kind of federal political system or a consociational regime. Scholars who draw on comparative federalism put emphasis on the strong dimension of territorial politics in the Community and concentrate on the problem of government representation in Community policy-making. Consociationalists emphasise the problem of cleavage structures of the Member States (ethnic, linguistic, cultural, institutional, economic, etc.). They concentrate, thus, on the settlement of divisive issues and conflicts in a largely non-consensual multinational context and the formal, informal and implicit rules that ensure 'elite accommodation' throughout the Community policy process, but also the 'trap of delegitimation' inherent to this kind of policy process. A sociological approach of the Community is still rare. But a promising approach may be to study Community integration and policy-making from the perspective of nation building. Following this perspective the Community must find a viable solution the centreperiphery problem and the problem of how to balance the free market and Community intervention.

Hix's idea to study the Community from a comparative perspective provoked much criticism. Hurrell and Menon ${ }^{40}$, for instance, argue that Hix has based his analysis upon an untenable distinction between integration and 'politics'. Integration is as political as other substantive policy issues in the Community. Even more important, as neofunctionalists have always put forward, they are very much intertwined. Common policy-making in substantive policy areas will lead to further institutional developments at the supranational level. In the view of Hurrell and Menon,

"an exclusive and excessive concern with the 'grand bargains' of integration, as evinced by many international relations theorists, provides a misleading picture of an integration process which often proceeds 'informally'"."4l

We fully agree with the emphasis of Hurrell and Menon upon the critical link between integration and politics.

More problematic, however, is their argument that Hix (and other comparative analysts) misunderstands the Community by treating it as a nation state. We believe that this argument is not valid. Comparative analysts do not argue that the Community is a nation state. They only postulate the existence of similarities between the 
Community and the nation state. They are not comparing apples with oranges. As William Wallace put it "the Community incontestably represents a new level of government", simply because it possesses authority and resources, which effectively limit the behaviour of the Member States.

\begin{abstract}
"Whether (the Community) is above, alongside, or outside the nationstates which are its members is a matter for semantic disputation; the governments and political processes of those states are so closely enmeshed in its operations in particular sectors of policy as to make all of these terms oversimplifications ",
\end{abstract}

William Wallace and other commentators argue on the basis of the incorporation of a wide range of policy issues into the Community agenda from the outset. The initial acceptance by the member governments of the removal of barriers to trade, competition policy, commercial policy and agriculture was followed by the development of regulatory policies in environment, consumer protection and public health. The Community has now developed a regional policy, and to a limited extent a research policy. On a modest scale it allocates resources within sectors of policy such as public health. It has authority over the value of the national currency, the central symbol of sovereignty and an instrument of national economic management. The extent of Community policy-making, established in agriculture, trade, economic and monetary policy, is still lacking in areas of social policy and/or social security and health care. Nevertheless, it takes the Community into significant and sensitive areas of domestic health politics.

Therefore, in their view, it makes sense to compare the Community with the nation state. The critical question, is whether a comparative analysis of the Community yields new interesting insights into the structure and dynamics of the Community as well as into the basic similarities and differences between the Community and the nation state. In other words, does the Comparative Politics approach provide added value to the study of the Community? It is beyond the scope of this study to give an in-depth answer to this question as there are many different politics which could be considered.

Having accepted that the Community does represent a new level of governance, successive commentators suggest political concepts and principles derived from the study of the nation-state to the extent that help us to better understand the presence (or absence) of Community authority, the established framework of policy, the repartition of competencies between the national and the European level within this particular sector of policy, the rules and the procedures for the adoption of specific acts, interest formation and intermediation and more generally Community policy-making. Yet, the Treaties are not constitutions. Norms, rules and decision-making procedures may exist, but the Community authority is still actively contested and the balance between Community and national authorities unsettled. Comparisons, therefore, provide a useful way to understand better the classical political questions of authority, legitimacy, accountability, effectiveness and justice, all the structural problems related to the governance that the Community must solve in order to develop further in future.

Before discussing Community policy-making in the health sector we should emphasise that there is a clear relationship between the Community's limited legitimacy and the 
problems of transfer of authority over health matters to the Community level. In the following chapters, we will be concerned with developing an analytical framework to discuss how and why the Community has been involved (or not involved) in health policy matters. Comparative analysis points out that, even in Community policy sectors operating within a relatively well established consensus, the principles are in dispute, the rules are not yet defined or constantly redefined and the objectives hotly contested. While this applies also to Community policy-making in the health sector, our analysis is faced with even more difficulties. The Maastricht and Amsterdam Treaties have registered only a limited consensus upon developing public health policy as well as about objectives and procedures. Thus, policy-making in this field lacks a coherent institutional structure. It displays characteristics markedly different from those within established Community institutional structures which articulate issues, conflicts, negotiation and choices, and thus focus the debate.

It should also be stated that patterns of policy-making in the health field are markedly different from those in the Member States because the issues at stake are different. The financing of social security programmes, "the right to health care", the access to available or new health services, their financing and organisation, all are predominant issues within national agenda. Whether proposals are based on Article 100,100a, or other specific articles, we shall see in the next chapter that health and safety issues dominate Community agendas mainly through their limits to the regulation of the internal market programme.

Issues of harmonisation of social security and the establishment of Community social rights (and health rights) were there within the Treaties, but largely in non-specific and conditional terms. In chapter six, we shall see that the Social Charter and the Agreement on Social Policy (the Social Protocol) establish a framework for governments, Community institutions, trade unions and employers, which may help to focus debate around those issues. However, we find that this structure is not a forum for debating Community social rights. It is also not suitable for clarifying the implications of monetary union, the Maastricht criteria and associated rules for budgetary policies, for national health policies. The Community was given authority over national currencies, and, implicitly or explicitly, over domestic budgetary policies, but it lacks the capacity, structure, budget and even the legitimacy to discuss and develop a more active role in social security and health care policy.

In chapter seven, we find that the new public health provisions codified the lack of consensus over Community policy in health care by explicitly excluding Community intervention in the financing and organisation of care. No one really expected that the next revision of the treaty (the Amsterdam Treaty) would change the limited consensus over Community public health action, whether in the field of prevention or research, which was registered in Maastricht. The BSE crisis revealed that health and safety issues, which were traditionally dealt with by ministries for health at the national level, were treated as agricultural or internal market matters at the Community level. The chapters that follow discuss all these issues, the way in which they entered the Community agenda; and which issues became more important than others and why. 


\section{Chapter Four References}

1 S. Hix, The Study of the European Community : The Challenge to Comparative Politics, West European Politics, Vol. 17, No 1, January 1994, p 1-30.

2. ibid, p.1

3. K. Goldmann, International Relations: An Overview, in R. E. Goodin and H-D Klingemann, A New Handbook of Political Science, Oxford University Press, 1996, p. 404.

4 E. Haas, The Uniting of Europe: political, social and economic forces, 1950-1957, Stanford University Press, second edition, 1968, p. 16.

5. L. Cram, Policy - making in the EU, London and New York: Routledge, 1997, p. 11.

6. Haas E. The uniting of Europe: political, social and economic forces, 1950-1957. Stanford: Stanford University Press, 1958, 1968, author's preface.

7. Also see, L. N. Lindberg, The Political Dynamics of European Economic Integration, Stanford University Press, 1963.

8. See C. Webb, Theoretical Perspectives and Problems, in H.Wallace, W. Wallace and C Webb (eds), Policy Making in the European Community, 2nd edition, John Wiley and Sons, 1983.

9. C.Offe, Disorganized Capitalism, Polity Press, 1985.

10. Quoted by M. A. Pollack, Creeping Competence: The Expanding Agenda of the European Community, Int. Journal of Public Policy, vol. 14, number 2, pp. 95 - 145.

11. P. Taylor, The New Dynamics of EC integration in the 1980 s, in J. Lodge (ed.), European Community and the Challenge of the Future, London: Pinter Publishers 1989.

12. For the classic statements of realism and neorealism see, respectively, H. J. Morgenthau, Politics among Nations, Knopf, 1948; and Keneth N. Waltz, Theory of International Politics, Addison - Wesley, 1979. For the development of Community intergovernmental (realist) practices see, J. Lodge, EC Policymaking: institutional considerations, in idem (ed.), The European Community and the challenge of the future, London: Pinter Publishers, 1989.

13. S. Hoffmann, Obstinate or Obsolete: the fate of the nation-state and the case of Western Europe, Daedalus, Vol. 95, 1966, p 862-915.

14. See C. Webb, Theoretical Perspectives and Problems, in H.Wallace, W. Wallace and C Webb (eds), Policy Making in the European Community, 2nd edition, John Wiley and Sons, 1983.

15. D. R. Cameron, The 1992 Initiative: Causes and Consequences, in A. M. Sbragia (ed.), Euro-politics: Institutions and Policymaking in the "New" European Community, Washington, D.C.: The Brookings Institution, 1992.

16. S. Hoffmann, Obstinate or Obsolete: the fate of the nation-state and the case of Western Europe, Daedalus, Vol. 95, 1966, p 862-915. 
17. ibid, $\mathrm{p} 882$

18. ibid, p.909, p. 910.

19. See A. Moravcsik, Negotiating the Single European Act, in Keohane and Hoffmann (eds.), The New European Community, Boulder: Westview Press, 1991, pp. 41 - 84. and idem, Preferences and Power in the European Community: A Liberal Intergovernmentalist Approach, Journal of Common Market Studies, Vol. 31, No 4 (December), PP 473 - 524.

20. A. Moravcsik, Preferences and Power in the European Community: A Liberal Intergovernmentalist Approach, Journal of Common Market Studies, Vol. 31, No 4 (December), PP 473 - 524.

21. C. Webb, Theoretical Perspectives and Problems, in H.Wallace, W. Wallace and C Webb (eds), Policy Making in the European Community, 2nd edition, John Wiley and Sons, 1983.

22. R. O. Keohane and J. S. Nye, Power and Interdependence: World Politics in Transition, Boston: Little Brown 1977.

23. C. Offe, Disorganized Capitalism: Contemporary Transformation of Work and Politics, Oxford: Polity Press, 1985; S. Lash and J. Urry, The end of Organized Capitalism, Oxford: Polity Press, 1987; and S. Holland, Uncommon Market, London: Macmillan, 1980.

24. M. Aglietta, A Theory of Capitalist Regulation: The US Experience, London: New Left Books, 1987; See also J. Grahl and P. Teague, The Cost of Neo - Liberal Europe', New Left Review No 114 (1989), PP 33-49.

25. D. R. Cameron, The 1992 Initiative: Causes and Consequences, in A. M. Sbragia (ed.), Euro-politics: Institutions and Policymaking in the "New" European Community, Washington, D.C.: The Brooking Institution, 1992, p. 30.

26. A. M. Sbragia, Introduction (p 13), in idem (ed.), Euro-politics: Institutions and Policymaking in the "New" European Community, Washington D.C.: The Brooking Institution, 1992.

27. S. Hix, The Study of the European Community : The Challenge to Comparative Politics, West European Politics, Vol. 17, No 1, January 1994, p 1-30, p 22.

28. Gerda Falkner, EU social policy in the 1990s: towards a corporatist policy community, London/New York, Routledge, 1998.

29. ibid.

30. See A. M. Sbragia, in idem (ed.), Euro-politics: Institutions and Policymaking in the "New" European Community, Washington D.C.: The Brooking Institution, 1992.

31. ibid, p 277.

32. A. Lijphart, the Politics of Accommodation: Pluralism and Democracy in the Netherlands, Berkeley and Los Angeles: University of California Press, 1968. See also, A. Lijphart, Democracy in Plural Societies: A Comparative Exploration, New Haven and London: Yale University Press, 1977. 
33. S. Hix, The Study of the European Community : The Challenge to Comparative Politics, West European Politics, Vol. 17, No 1, January 1994, p 1-30, p 20.

34. P. Taylor, The European Community and the State: Assumptions, theories and propositions, Review of International Studies, no 17, 1991, p 109-25.

35. F.W. Scharpf, Essai sur la democracie dans les systemes de negotiation, in M. Telo (ed), Democracie et Construction Europeene, Editions de l' Universite de Bruxelles, 1995.

36. ibid, p 152.

37. See G. A. Almond, Comparative Political Systems, Journal of Politics 18/2, 1956. See also G. A. Almond, A Discipline Divided: Schools and Sects in Political Science, London: Sage Publications, 1990.

38. See J. E. Lane and S. O. Ersson, Politics and Society in Western Europe, London: Sage Publications, 2nd edition, and 1991.

39. S. M. Lipset and S. Rokkan, Cleavage Structures, Party Systems and Voter Alignments: An Introduction, in idem (eds.), Party Systems and Voter Alignments: Cross-national Perspectives, NY: Free Press, 1967.

40. A. Hurrel and A. Menon, Politics Like Any Other? Comparative Politics, International Relations and the Study of EU, West European Politics, Vol. 19, No. 2 (April 1996), pp. 386-402.

41. ibid, p 389.

42. W. Wallace, Less than a Federation, More than a Regime: the Community as a Political System, in H. Wallace, W. Wallace and C. Webb (Des), Policy-Making in the European Community, John Wiley\&Sons, 1983, p 407. 


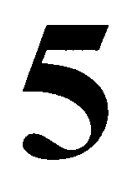

\section{European Community Harmonisation \& Spillovers into Health Regulation}


Based on Maria Theofilatou and Hans Maarse "European Community Harmonisation and Spillovers into Health Regulation" in R. Leidl (Ed.) Health Care and its Financing in the Single European Market, IOS Press: Amsterdam, 1998; 13-37.

\section{Introduction}

Health entered the institutional policy agenda of the EC only recently. The European Union's Maastricht Treaty introduced a legal basis, for action in the field of public health (article 129). Although public health policy is now often associated with provisions from the Maastricht Treaty, the latter actually represent only a step in the institution-building process that public health issues have been undergoing since the establishment of the EC. Community health legislation has developed incrementally since the 1950s and is characterised by a smattering of Regulations and Directives over various policy fields. Legislative action in the field of pharmaceuticals, for example, developed since the early 1970s, and is composed almost entirely of Community Directives regulating aspects such as the health and safety standards for their production, marketing and post-marketing control in the common market. Health protection measures became a constituent part of the environment and consumer protection policies, both of which also developed since the early 1970s, and consist of Community Regulations and Directives which regulate the activity of private actors. In social policy, legislative action in the field of social security has developed since the 1950 s and consists almost exclusively of Community Regulations which aim at protecting the rights of workers who cross borders within the Community. In addition, legislative action in the field of occupational health and safety that developed since the 1970s, was also accelerated in the 1980s and consists of Community Directives regulating minimum standards in this field.

It follows that there has been some harmonisation of certain aspects of member countries' health policies. The record of Community harmonisation in the field of health policy prompts us to ask the following questions: To what extent has health regulation of Member States been subjected to harmonisation by direct EC intervention? In which policy fields does this happen and in which not? How can we explain the variations in policy development from one policy field to another?

We begin first with a brief review of the theoretical literature on task expansion. Next, legislative data are presented. The principles underlying the process of Community regulatory harmonisation are discussed. The institutional decision rules governing the making of EC legislation are briefly outlined. Following these observations, the nature and content of legislative interventions, here termed direct harmonisation*, are

* Ingalil JM uses the term direct harmonization to refer to the planned consistencies in policies imposed by the EC authorities, that is as a result of political decision-making at Community level. He uses the term indirect harmonization, on the other hand, to refer to the final outcome of similarity as a result of the planned consistencies as well as for other economic, political and social forces [1]. 
examined. Fields examined include medicines, environment, consumer protection, health and safety for workers, as well as education of health professions and social security. Task expansion into health regulation is explained largely in terms of the functional linkages between specific EC interventions and the common market. General tendencies in each of the particular fields are discussed in order to establish the EC legislative choices.

\section{Task expansion: the theoretical background}

The term task expansion is borrowed from the neofunctionalist literature on regional integration. Neofunctionalism represents the primary theoretical effort used to explain the process of task expansion in the EC and provides long term predictions about future European integration. Haas applied the concept of task expansion in his early and classic theoretical study of the European Coal and Steel Community (ECSC) ${ }^{2}$.

Haas's process of functional and political spillovers, in which the initial decision by governments to place a certain sector (such as coal and steel) under the authority of the Community institutions inevitably creates pressures to expand the authorities of institutions in other policy sectors (such as currency exchange rates, taxes and wage policy). Furthermore, the number of claims and demands through EC institutional forms and practices, reinforces the authority of the system as a whole. As a result of this spillover process, neofunctionalism predicts the movement from 'negative integration' (the removal of barriers to trade) to positive integration (the proactive coordination of common policies).

Lindberg also applied the concept of spillovers in his early theoretical study of the European Economic Community (EEC). According to Lindberg,

"spill over refers to a situation in which a given action, related to a
specific goal, creates a situation in which the original goal can be
assured only by taking further actions, which in turn create a further
condition and a need for more action and so forth" 3 .

Haas saw the Community as a new and singular system, neither international nor national but supranational. That is to say, the EC involves the existence of governmental authorities closer to the archetype of a federation rather than any past international organisation, although, it is yet to be identical to it. Moreover, Haas' political analysis puts emphasis on a problem inherent to the institutional logic of the common market. That is, the political problem with respect to compensating for market failures, supervising rules, resolving conflict, fine-tuning, and providing public goods.

The policy framework indicated in the treaties stressed the virtues of a free competitive economy and held that improvements in living and working conditions were to be achieved as a result of more effective competition and trade rather than through direct planning. It is true, the treaties also allowed the development of macroeconomic and welfare policies. Any single Member State still had the power to veto proposed fiscal, labour, and welfare measures in the Council of Ministers. 
Haas took into account the limitations of a strong free market bias in the European project of economic integration. Nevertheless, he put emphasis and indeed relied on, the formation and action of transnational interest groups such as unions and employer organisations, investors and consumers, higher civil servants and politicians. $\mathrm{He}$ suggested that interest groups operating in an integrated sector would seek to eventually shape the making of EC policy decisions, and thereby transfer their loyalties, demands and expectations from national governments to new central institutions charged with running their sector. Spillovers were therefore based on interest groups politics, where rational actors were expected to pursue their interests and hence become an important force in favour of further integration.

On the other hand, Haas saw the role of the Commission (or the High Authority as it was then, which performed the executive and mediative functions) as an important agent of the spillover process. Indeed, the Treaty of the European Coal and Steel Community assigned a formidable array of rule making powers to the Commission. The Commission would seek to organise a consensus among all interested parties before embarking on any policy. Contacts between transnational interest groups and national civil servants were multiplied enormously by this practice which also facilitated the evolution of a consensus on specific issues. Administrators in the Commission may thereby shape the outcome of the multiple interactions among the political elite and link the policy outcome to an expanded mandate at the centre.

In effect, conditions concerning both group and institutional behaviour in the $\mathrm{EC}$ have been extensively criticised ${ }^{[4-7]}$. One of the important biases of neofunctionalist theories is that they tend to take interest representation as an independent variable rather than a variable dependent of public policy-making. At best, neofunctionalism assumes that interest organisations such as unions, trade organisations employer and consumer associations enjoy equal access to the Community policy process. We may also say that neofunctionalism overlooks the relevance of social and economic factors that affect the existence, strength, and articulation of interest organisations in the EC context. Indeed, the existence and strength of European interest organisations depend also on the social realities of a group's members. Factors such as the strategic location of these groups within society and the politico-institutional status the organisation may have, are likely to effect public policy decisions [8].

Moreover, the development of active interventionist policies aiming at the satisfaction of manifest interest or 'anticipated interest' also requires the existence of sufficient fiscal and institutional resources at the disposal of the central institutions. Haas' objective of political rationality implies that the Commission would be able to serve as many of the specific demand inputs as possible, so as to accommodate a maximum amount of special interests. The experience of the $\mathrm{EC}$ has shown a considerable range of conflict over the evolution of its budget, the nature of its financing and the size and scope of policies which are more or less interventionist. Despite a significant upward trend in the 1980s, the Community budget remains much smaller than national 
budgets*. It represented only $1.24 \%$ of the Gross Domestic Product of the Member States in 1994 or about $2.4 \%$ of the total Member States' public expenditures [11].

The Community did not replicate the politics of welfare state development. The Community budget is still not concerned with social security issues that take a large share of national budgets. In addition, the institutional parameters that have been established guarantee that problems or demands that have to be dealt with do not exceed the scope of available resources. According to article 199 from the Treaty of Rome,

\section{"The revenue and expenditure shown in the budget shall be in balance".}

Thus, there is no such thing as a Community debt and therefore, none of the problems associated with the financing of national debts are possible. Furthermore, the Community revenue (and the expenditure) is limited by an overall ceiling on the resources available to it by the Member States, and this ceiling is also determined by the Member States.

On the other hand, the intergovernmentalist school of EC studies rejected the neofunctionalist prediction of spillover. Intergovernmentalist scholars such as Hoffmann assumed that governments would defend the national interest of their state and resist making concessions, or be unwilling to concede a role to international institutions in essential matters which touched on the independence or the 'sovereignty' of the state itself [12]. Rather, intergovernmentalists would expect governments to negotiate low sectoral matters that would not determine overall government policy. Accordingly, the EC would remain merely an institutional arrangement that facilitates intergovernmental co-ordination. It would act as an international rather than a supranational organisation.

Intergovernmental analysis has been undoubtedly helpful in specifying a predominant role for national governments in Community decision-making and has offered some dimension to the relationship between the EC and its Member States. Nevertheless, intergovernmental interpretations of the $\mathrm{EC}$ have not gone unchallenged. The EC accumulated more and more direct powers within its decision making structure, and governments have accepted being bound by Community rules over a widening range of significant policy sectors in recent years.

More recently, Andrew Moravcsik put forward a 'liberal intergovernmentalist' view of the EC which seeks to account for new political developments in European integration such as the Single European Act or the Treaty on European Union [13]. In this view, while member governments remain the primary actors in European integration, the interests and preferences of these actors are products of liberal interest group politics within each Member State. Governments then bring these preferences into intergovernmental bargains, which in turn reflect the preferences and bargaining

* For a detailed discussion about the budget as well as the decision rules governing the adoption of the Community budget see [9-10]. 
power of various member governments that have distributional consequences. As Moravcsik put it, in negotiating policy co-ordination within the $\mathrm{EC}$,

"the terms will favour those governments able to remove negative externalities by opening markets to which others intensely desire access, modifying policies others intensely desire to change, or distributing resources others intensely desire to share." [ref:13 p.499]

In short, Moravcsik agrees with earlier intergovernmentalist's analysis of the EC. He also adds an explicit theory of bargaining among governments, which address the conditions under which these governments might be willing to either pool or delegate sovereignty. Whatever the extent of the new and expanded powers of the Community institutions Moravcsik suggests that the ultimate authority for controlling domestic affairs continues to reside within the Member States.

This liberal intergovernmentalist approach provides useful insights into the nature and process of the recent intergovernmental bargains leading to the Single European Act and to the European Union Treaty. Nevertheless, it underestimates the EC as an organisation with its own resources and institutional policy outcomes. We would certainly agree that national governments negotiate and sign EC treaties. Indeed, the use of treaties institutionalise the importance of national governments, since by definition a treaty is only binding for those countries that sign it [14]. This also means that governments determine the extent of rights and resources that are attributed to the Community. Yet, once the process of treaty making is concluded, all Member States are bound legally. The pool of resources is no longer employed by the decisions of individual governments, but by the appointed EC institutions. As a result, a new kind of political order comes into being [15].

The EC not only represents new and changing pathways of transnational political governance, but also experiments with new ways of regulating the economy and society [16]. Accordingly, as the scope of Brussels' jurisdiction encompasses more and more areas of public policy (particularly in the economic sphere) the political controversy surrounding welfare issues increases. Even if the EC neither became the supranational state nor replicated the politics of welfare state that neofunctionalists predicted, we shall argue, that the concept of spillover remains a valuable first step in explaining Community task expansion into the health regulation of Member States. Before we proceed any further, we shall present some legislative data and discuss the principles underlying the process of Community regulatory harmonisation.

\section{Legislative data: preliminary presentation and analysis}

At its founding the Community had no health policy. Nevertheless, since the 1960s, there has been a steady increase in aspects of broad health issues incorporated into the legislative agenda of the EC (see Figures 1 and 2 on Health Regulation). However, there is a striking contrast between the heavily regulated policy areas of environment, consumer protection, occupational health and to a lesser extent medicines and health professions when compared with social security, which features few directives. Although accentuated by comparing the choice of directives as the measure of 
regulatory output, this contrast is nevertheless real and raises the question as to why the Community harmonisation of national regulations has grown incrementally for some health issues, while remaining restricted in others.

Under the Treaty of Rome, Community regulatory harmonisation is related to the functioning of the common market. Article 100 quite clearly provides for the,

"approximation of such provisions laid down by law, regulation or administrative action in Member States as directly affect the establishment or functioning of the common market" [17].

Article 100 also specifies the means for this kind of Community regulatory harmonisation and is the directive.

Figure 1: Number of directives in force, by policy area

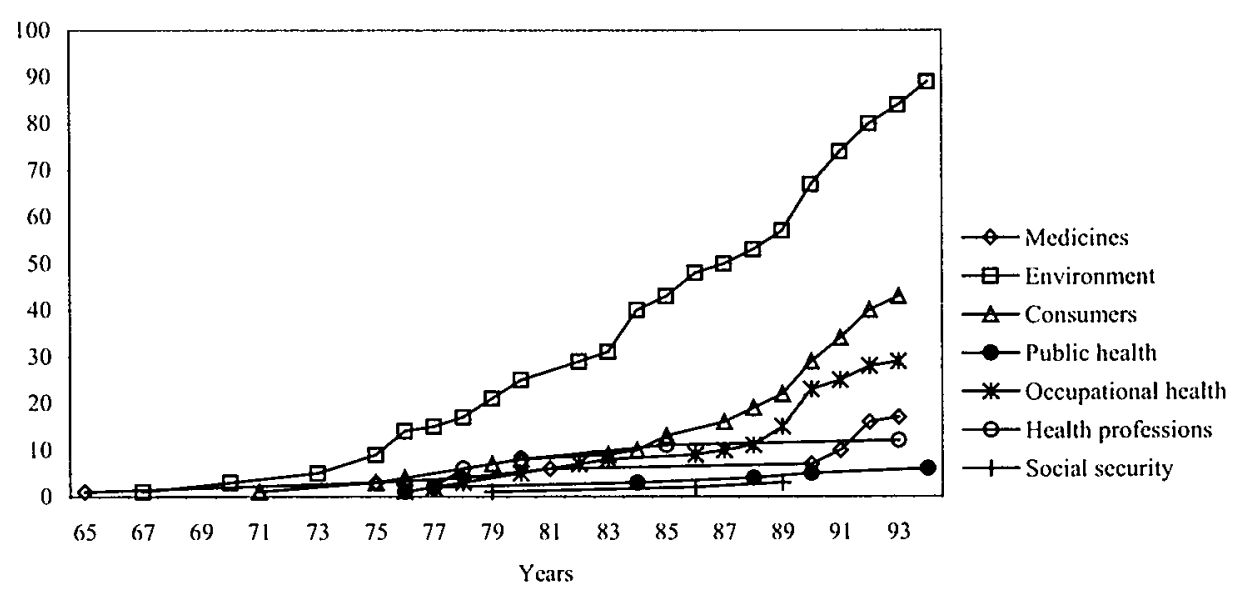

Source: based on data in: Journal Officiel des Communautés Européennes, Répertoire de la Législation Communautaire en Vigueur et d' Autres Acts des Institutions Communautaires, vol. 1: Répertoire Analytique, Bruxelles-Luxembourg: Communautés Européennes, 1995

It should be pointed out that a directive is only one form that Community legal acts may take. These acts may also take the form of regulations, decisions, recommendations or opinions. Recommendations and opinions do not bind Member States whereas regulations, directives and decisions do. Regulations are binding in their entirety and take immediate legal effect across the Community once adopted. There is no need for any national implementing measures. Directives are not binding in their entirety but are in 'the result to be achieved'. That is, they establish certain policy principles and allow each Member State a given period to implement them.

Typically this is done by enacting relevant legislation through parliament or relevant administrative circulars. Lastly, decisions are directed to those parties involved with a particular issue. 


\section{Figure 2: Number of directives in force, by policy area}

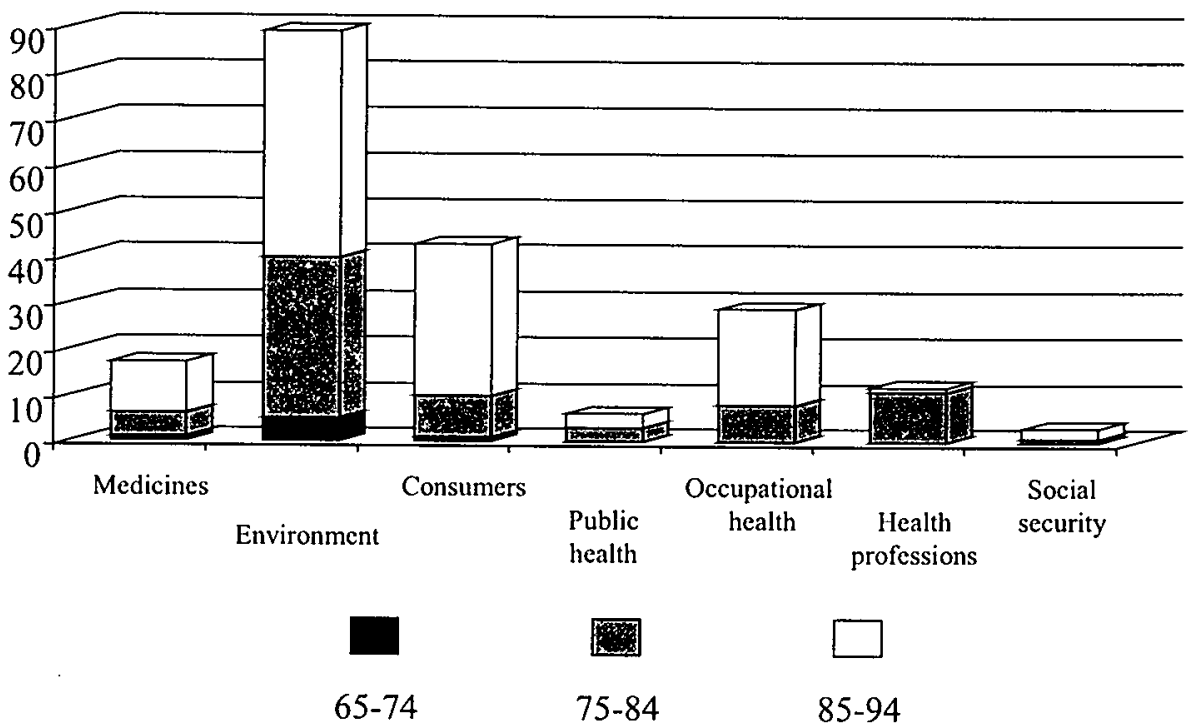

Source: based on data in: Journal Officiel des Communautés Européennes, Répertoire de la Législation Communatuaire en Vigueur et d' Autres Acts des Institutions Communautaires, vol. 1: Répertoire Analytique, Bruxelles-Luxembourg: Communautés Européennes. 1995

Moreover, recall that common market arrangements* entail first the removal of barriers that hinder the free movement of goods (especially industrial goods) within the EC and setting up a common tariff policy goods entering the EC. Tariffs, quantitative restrictions, as well as charges and measures having the equivalent effect of customs duties, and quantitative restrictions, need to be removed. In addition, the common market arrangement envisages the removal of barriers that hinder the free movement of factors of production such as capital, labour (and the professions) and enterprise, $\dagger$ as well as the institutionalisation of a system that ensures free competition within the common market.

* For a discussion of the economic principles underlying the creation of the common market see [18].

$\dagger \quad$ The free movement of goods was provided for in articles 9 to 37; the free movement of labour was dealt with by articles 48 to 51 ; the free movement of capital was covered by articles 67 to 73 ; the free movement of enterprise (known as the right to establishment) was dealt with in articles 52 to 58 while the free movement of services was governed by articles 59 to 66 . 
As far as barriers to intra-Community trade are concerned, both the removal of intraEC tariffs and the creation of a common external tariff were established one and half years ahead of schedule in 1968. Interest then shifted to the removal of a second type of barrier, generally referred to as non-tariff barriers (NTBs) to trade.

In principle, barriers such as the "quantitative restrictions on imports and all measures having equivalent effect" are prohibited under article 30 of the EC treaty. However, the treaty allows Member States, under certain circumstances, to continue to retain quantitative restrictions and measures which have the equivalent effect. Under article 36, Member States can justify these restrictions,

"on the grounds of public morality, public policy or public security; the protection of health and life of humans, animals or plants; the protection of national treasures possessing artistic, historic or archaeological value; or the protection of industrial and commercial property."

Thus, health protection measures have been invoked using these grounds for a ban on imports.

Article 100 provides the possibility to remove these restrictions through harmonisation of national regulations. According to article 100, Community harmonisation of national regulations arises insofar as these regulations impede free trade within the common market. It is this imperative to harmonise, which represents the primary instrument of functional spillovers from the common market to areas such as medicines, environment, and consumer protection.

As it has already been stated, various interest groups may come forward, seeking to influence EC policy decisions. Nevertheless, this can not automatically create policies. In this respect, in order to understand Community policies and interventions more fully it is essential show the ways which EC institutions make decisions. In terms of decision rules, the harmonisation process of article 100 was based on unanimous voting in the Council of Ministers, in the period prior to the Single European Act. The Commission had and still has the exclusive right to introduce proposals for Council legislation. The European Parliament was consulted on only one occasion. The Council was not under any obligation to take Parliament's amendments into account. However, the Commission used its agenda-setting power, to place before the Council a broad range of harmonisation proposals. Harmonisation proposals were frequently not adopted, since a single Member State could easily veto any proposed directive.

Thus, harmonisation under this 'legal and policy regime' proceeded slowly. A total of 158 directives were introduced by the Commission between 1968, when the first 'General Programme for the elimination of technical barriers to intra-Community trade' was launched, and 1983 [19]. Following the Single European Act, article 100 has been modified by the new article 100a. First, and most importantly, the unanimity 
voting rule was replaced by a required qualified majority voting in the Council.* The implementation of qualified majority voting has removed the ability of any single Member State to veto legislation. Proposals by the Commission are now more easily obtained and thus facilitate the adoption of directives relating to the establishment of the common market.

Moreover, the traditional system of one reading or consultation was replaced by a cooperation procedure i.e. a second reading for both the Parliament and the Council was introduced. The Parliament may accept, reject or propose amendments, which the Commission may or may not incorporate into its proposal to the Council. Parliamentary amendments rejected by the Commission require a unanimous vote by the Council to be introduced. If the Commission incorporates these amendments into its own proposal, the Council requires only a qualified majority vote to accept the proposal $\dagger$. However, rejected legislative proposals by the Parliament can still become law by unanimous vote in the Council.

We should emphasise that from the application of article 100a, topics relating to the rights and interests of employed persons were explicitly excluded as were those topics relating to fiscal provisions and the free movement of persons. In keeping with the concept of the common market, the Treaty of Rome provides for the free movement of labour (workers) and the right of establishment for self-employed professionals (articles 48-51). Regarding the free movement of workers, article 51 enables the Council,

\section{"acting unanimously on a proposal from the Commission, to adopt such measures in the field of social security as are necessary to provide freedom of movement for workers."}

Although, article 51 does not provide for the harmonisation of social security rights in the Community, it has had an important spillover, into the social security legislation of Member States. Moreover, article 57, which deals with the right of establishment for self-employed professionals, has also been an important source of functional spillovers

\footnotetext{
* Under the voting rules for qualified majorities France, Germany, Italy and the UK have 10 votes each; Spain has 8; Belgium, Grece, the Netherlands, and Portugal have 5; Austria and Sweden have 4; Denmark, Ireland and Finland have three; and Luxembourg has 2 . Of this total of 87 votes, 62 constitute a qualified majority and 26 a blocking coalition [20].

$\dagger$ The Single Act introduced qualified majority voting in the Council and second readings or the co-operation procedure for some ten articles relating to the internal market, but also to the decisions on the specific action programmes in regional policy, and research and development policy. In addition to the consultation and $\mathrm{Co}$ operation procedures, the last Treaty on European Union introduced a third procedure called the co-decision procedure. The co-decision procedure replaces the Co-operation procedure for some of these articles relating to the internal market, and most importantly for article 100a. The new procedure applies also to the adoption of gencral action programmes in many policy areas: social policy, public health, culture, education, research framework programme, environment and consumer protection. However, the legislation presented in this paper was adopted under the rules of the Co-operation procedure and we, therefore, do not discuss further the rules of the new co-decision procedurc.
} 
from the common market to the education of health professions, and most importantly to the harmonisation of professional training requirements.

The second strand of the Community harmonisation process relates to social policy (articles 117-127). Under the Treaty of Rome, article 117 looks at the need to promote working and living conditions, as well as social harmonisation. According to this article, Member States,

"believe that such a development will ensue not only from the functioning of the common market, which will favour the harmonisation of social systems, but also from the procedures provided for in this Treaty and from the approximation of provisions laid down by law, regulation or administrative action."

Further, article 118 indicates a number of social policy areas and includes matters relating to employment, labour law, basic and advanced vocational training, social security, prevention of occupational accidents and diseases, occupational hygiene, the right of association, and collective bargaining between employers and workers.

The essential message of articles 117 and 118 is the desirability of social system harmonisation. However, the Community was not given the power to harmonise national legal frameworks. For most social issues, including social security and occupational health, no specific targets were set and no timetables were laid down. Again, action in social security was limited to issues relating to the free mobility of workers. Article 121 enables the Council, acting unanimously to,

"assign to the Commission tasks in connection with the implementation of common measures, particularly as regards social security for the migrant workers referred to in articles 48-51."

Following the Single European Act, the only social policy area where the Community was given the power to harmonise national legislation, was health and safety for workers, and more generally, conditions in the working environment (118a). In accordance with the new article $118 \mathrm{a}$, the harmonisation directives would only require a qualified majority vote in the Council of Ministers. It should be pointed out that Community harmonisation of national health and safety measures for workers started even before the introduction of the new article 118a. Essential to the harmonisation of national legislations in this field was the view that differences in working conditions, (conditions of production) might lead to distortions in competition within the EC (thanks also to article 100a). Once again, the shape of Community regulatory policy was determined largely by the existence of the specific policy area dealing with free movement.

After the above discussion on the process of Community regulatory harmonisation, we have to recognise that it relates to the dominant economic rationale of the EC. Namely, the objective of creating a common market. In principle, Community harmonisation of national legislation arises insofar as national regulations impede free trade within the common market. The harmonisation of health and safety legislation in the fields of environment, consumer protection, occupational health, and medicines, may also be seen as an example of re-regulation taking place at the Community level. Nevertheless, 
it appears that what has passed as health and safety regulation in the EC is better understood as health and safety regulation for the proper functioning of the common market.

The changes introduced by the Single European Act and the Treaty on European Union altered the institutional rules governing the Community harmonisation process as well as the Community's health and safety policy agenda. Qualified majority voting removed the ability of any single Member State to veto proposed legislation by the Commission and thus accelerated the process of harmonisation in all the fields mentioned above. In addition, second readings and the co-operation procedure allowed the Parliament, together with the Commission, to make amendments to Council Directives.

Although the Maastricht Treaty extended the authority of the Community in public health, the Council (that is the Member States) avoided explicitly establishing any direct harmonisation policy, in the sensitive sector of social and health care. Article 129(4) states clearly that the Council

"...shall adopt incentive measures, excluding any harmonisation of the laws and regulations of the Member States."

The EC has not attempted to directly harmonise the social and health care policies of the Member States. However, the free movement of persons has been an important source of spillovers into the education of health professions as well as the coordination of social security legislations to protect the rights of migrant workers and self employed migrants*.

\section{Free movement of goods and EC policy in the field of medicines}

The EC initiated a process to remove non-tariff barriers (NTBs) from intra-Community trade for human and veterinary medicinal products in the early 1960s. For almost twenty years, the Community legislative harmonisation has been directed to ensure the free movement of pharmaceuticals by means of institutionalising the mutual recognition of national product authorisations. In the case where health and safety considerations could justify the existence of different national marketing regulations, the only way to remove NTBs to trade was through the harmonisation of the national evaluation and licensing procedures for drugs. The EC had thus acquired power as a regulator, in order to insure that medicines produced and registered in one Member State were both safe and effective for sale in other Member States.

As it was said above, the process of legislative harmonisation (article 100) was slow in the period prior to the Single European Act due to the unanimous voting requirement in the Council of Ministers. The introduction of qualified majority voting (article

* For a discussion about the impact of the single market on national health policies see [21]. 
100a) facilitated the adoption of thirteen proposals relating to pharmaceuticals that were put forward by the Delors white paper on the internal market. Responsible for the harmonisation of the national marketing regulations was Directorate General III (Internal Market and Industry).

As a result of the harmonisation process, a volume of Community legislation essential for health protection was produced. A new EC decision making process for drug approval was also introduced [22]. The new system involves three approaches: a European Agency for the Evaluation of Medicinal Products (EMEA), which handles central EC arrangements for licensing of medicinal products derived from biotechnology and other innovative products as well as issues a single Community wide authorisation which is valid in all Community Member States; a decentralised licensing procedure, which applies to the majority of medicinal products, permits the extension of a marketing authorisation granted by one Member State to one or more other Member States through a process of 'mutual recognition' (this procedure will become obligatory after 1998 for all requests to market a product in more than one Member State) and in the case of serious objections EMEA steps in to arbitrate in disputes; and a national procedure, limited to the requests to market a product in a single Member State.

The EC system of drug approval has to demonstrate its contribution towards the overall aim of promoting public health and ensuring the quality, safety and efficacy of medicinal products circulating within the Community or exported from it. Having said that, we should not forget that economic preoccupation dominated the vision of the Commission on drug legislation and registration. From the end of 1980s, the development of a single market for drugs was stated as a strategy to enhance the competitive strength of the European pharmaceutical companies vis-à-vis the USA and Japanese companies. Because of the actual and potential implications as well as the possibilities for developing new drugs, biotechnology has occupied a prominent place in the European public debate and in the Community regulatory framework.

In the words of the Vice President of the European Federation of Pharmaceutical Associations, it was not merely the European idea that convinced the industry about the necessity of an EC system for drug approval [23].: as a result of the new system of drug approval, the industry anticipates more rapid introduction of drugs in all EC countries. It also expects that a European registration dossier of high standard may convince American and Japanese authorities to take part in a single registration procedure.

As a part of its strategy to enhance innovative Research and Development in the European pharmaceutical industry, the European Commission has also introduced a Regulation on Supplementary Protection Certificate (SPC) for innovative drugs, which took effect on January 2, 1993 [24]. The SPC extends the effective patent protection for pharmaceuticals, with a maximum duration period of five years. In principle, the SPC compensates for the erosion of effective patent protection. These extended patents are needed to compensate for the years spent on research, development and registration procedures. The introduction of the supplementary protection certificate for the EC market can also be considered as a European policy response to the drugs 
patent extension law that was enacted in USA in 1984 and in Japan in 1986. In total, the EC regulation has provided the industry with an effective 15 year marketing exclusivity period, including protection by the basic patent and certificate protection.

Additional patent protection in the EC prevents generic producers from starting development of generic alternatives before the end of market exclusivity period. In the USA, for example, pharmaceutical companies are allowed to research and register new generic products while a drug is under patent. In Europe this is illegal. Some commentators argue that the EC's additional protection law may lead to higher consumption prices for existing drugs and, thus to rising costs to be paid out through premiums and direct consumer co-payments [25].

The regulatory power of the EC in drug legislation has increased, but the EC has limited powers to intervene and harmonise national regulation instruments and social security legislation on matters of drug pricing and reimbursement. The Council's directive 89/105/EEC constitutes the only EC legislation on medicine's pricing and reimbursement and is known as the 'transparency directive'. This directive does not attempt to harmonise prices themselves, but lays down rules on the regulation of prices by Member States. Its aim is to ensure that national decisions on price control and reimbursement are made visible and do not constitute quantitative restrictions to trade. Transparent prices, mean the regulation of prices in Member States can no longer favour domestic over foreign pharmaceutical suppliers. The transparency directive also lays down rules regarding decisions on pricing and reimbursement time limits and options for appeal for the concerned parties against the measures and a framework for information exchange. The Commission was required to offer a new proposal on transparency at the beginning of 1992.

Up until now, attempts by the Commission to define pricing and reimbursement issues have not been fully effective. Potential implementations of the internal market were watered down, with the help of the European Court of Justice. The case 249/99 has stressed the fact that EC law provides the Community authorities with power to ensure that no discrimination by a single country against imported drugs occurs. Still, this does not affect the power of Member States to regulate prices, reimbursement and profits. Accordingly, the Commission has ceased presenting new proposals about price regulation, control and social health insurance [26].

From the end of 1980s, the Commission's suggestions as market-economy regulator, linking price regulation to the internal market, were meant to increase price competition. Instead of state price and prescription controls, the Commission suggested restricting the growth of public pharmaceutical expenditure through increasing patients' co-payments, encouraging the use of over the counter medicines and promoting the private purchase of prescription medicines [27]. In addition, the Commission argued that direct price controls were ineffective because they only control prices and not volumes, they reduce profits, and reduce the possibility for further research and development.

There is a multitude of national regulation instruments and legislation, on matters of price control, profit margin controls, reimbursement policies, as well as positive and negative medicines lists. Most of the Member States regulate the prices of individual 
products [28]. Product by product price control is used in France, Belgium, Italy, Spain, Greece, and Portugal. Reference pricing, which is common in the Netherlands, Germany, Denmark and Sweden, standardises a basic price for entire drug classes. The insured person pays any excess above the reference price. Controlling pharmaceutical company profits rather than the price of their products is a method of control unique to the United Kingdom. Almost all countries set strict criteria or set different degrees of reimbursement for medicines. In addition, positive and/or negative lists are used to indicate which drugs permit reimbursement. Patient co-payment systems are used by all countries.

The array of regulatory controls contributes to considerable price differences among Member States. Wide price differentials exist within the EC for the same medicinal product. However, the number of directly controlled prices tends 4 to be low. Countries such as Greece and Portugal spend much more on pharmaceuticals relative to their total health budgets when compared to wealthier states of the Community. France combines low prices with high domestic pharmaceutical consumption and high medicine costs per head. In general, the northern EC states with the highest medicine prices at home also have the most successful foreign trade records (the Netherlands is an exception) and the lowest volumes of domestic prescribing (Germany is an exception).

The perpetuation of high price differences for different member countries seems at the very least inequitable. In the case of high price differences between identical branded drugs, the Commission has tolerated parallel importing. That is, the practice of buying licensed branded medicines from low-price countries and selling them to high-price countries. Although, this practice has grown, the market shares of parallel imports have never reached high enough levels to significantly influence relatively highpricing countries. In addition, the counter-argument to parallel importing is that lower earnings can jeopardise future research for pharmaceutical companies. On the other hand, too rapid transition to even pricing across Europe might cause real problems in countries with low incomes or a high use of medicines [29].

Overall, it may be said that in the future Community countries will continue to apply their pricing and financing systems and put limits on the marketing strategies for pharmaceuticals. However, it is possible to argue that common criteria can be established in relation to the preventive and therapeutic value of innovative drugs approved by the European Medicines Agency. In assessing new drugs, the agency's responsibility is to apply safety, quality and efficacy criteria. But the criteria are not established concerning the value of certain drugs. Perhaps, such a procedure could lead to convergence of price levels between countries' new drugs.

\section{Free movement of goods, and environmental, consumer and public health protection policies}

As discussed above, the Treaty of Rome contains no explicit reference to environmental, consumer and public health protection policies. Nevertheless, the earliest and most remarkable spillovers from the free movement of goods occurred in 
environmental health and consumer protection. In 1972, the European Council requested the Commission to develop a Community environmental policy. The Council of Ministers adopted the EC's first action programme for the environment in 1973. The first programme for consumer protection was approved in 1975. Community harmonisation then moved into the area of process harmonisation or the regulation of industrial production, to eliminate large differences in national regulation which potentially create significant non-tariff barriers to trade.

The first directives were adopted in the late 1960s and early 1970s. The legal basis was contained in article 100 , sometimes in combination with article 235 of the EEC Treaty. As was pointed above, article 100 authorised the harmonisation of all national regulations that affected the establishment of the common market. Article 235 provides that the Council acting unanimously on a proposal from the Commission after consulting the Parliament, could take appropriate measures if: such measures are necessary to attain one of the objectives of the Community, and this Treaty has not provided the powers necessary to take those measures.

Despite the requirement of unanimous voting in the Council, there has been a steady expansion in the scope of Community environmental (and consumer) regulations between the early 1970s and the mid-1980s. The EC legislation enacted during this period affected public health although this was not stated as an explicit objective in the texts. Directives, regulations and decisions covered industrial emissions, prevention of accidents, safety requirements for chemicals, water, air and noise pollution, and the transfer and disposal of waste. Environmental policy made it possible to argue, even in the early 1980s, that the EC had come to play an important role as the nation state $[30,31]$.

As mentioned above, under article 100 of the Treaty, the harmonisation of environmental regulations could be justified largely in terms of the functional linkages between specific policy areas and the common market. Indeed, most national governments significantly expanded and strengthened the scope of their own regulatory controls over industry during the late 1960s and early 1970s. Differences in national regulations posed a potentially serious threat to the free movement of goods within the EC. In the case of production standards, countries that had adopted more stringent controls than other member countries, were forced to choose between excluding goods produced by countries with weaker regulatory requirements or lowering their standards to those of the least regulated Member State. In the 1970s, for example, Germany adopted a series of strict environmental regulations on automobiles, petrol, and other industrial products; and these regulations, if unharmonised at EC level, would create significant non-tariff barriers to trade [32].

Following the revision of the Treaty of Rome by the Single European Act, the new article $100 \mathrm{a}$ stated explicitly that in harmonising national regulations for the common market,

"the Commission in its proposals ...concerning health, safety, environmental protection and consumer protection, will take as a base a high level of protection." 
Furthermore, a new title on environment, consisting of articles 130r, 130s, and 130t, was introduced into the Treaty of Rome. Both articles 100a and 130t explicitly allowed Member States the right to maintain or enact stricter environmental regulations than those approved by Brussels, provided that they did not openly constitute non-tariff barriers to trade. The Court of Justice was left to interpret whether a national regulation created a barrier to trade. The last treaty of the European Union further expanded the Community's environmental competence and introduced new titles on consumer protection (article 129a) and public health (129).

As we said above, under article 100a, legislation proposed by the Commission could be adopted on a qualified majority voting basis by the Council. Under the new environmental provisions, the approval of proposed legislation required unanimous voting in the Council. Between 1989 and 1991, the EC enacted more environmental legislation than in the previous twenty years combined. Most of the environmental directives enacted have been based on article 100a [31]. In the area of environment, as in consumer protection, the shift to qualified majority voting in the Council facilitated the adoption of directives that had hitherto been held up by national vetoes. However, the Commission's proposals were ultimately adopted for the proper functioning of the common market and never for their own sake.

There have been many controversial issues, some of which remain a bone of contention. Examples of these may include automobile emissions, the regulation of biotechnology and the recent crisis due to cattle brain disease. In the case of automobile emissions, it was argued that the enactment of stricter laws by some countries may drive the Community to establish stricter, Community-wide standards [33]. The Commission introduced a proposal for small-car emission standards to the Council in 1988. It proposed that emissions from small cars would be reduced by $58 \%$ by 1992-1993. The directive, which was finally adopted in 1989, required small and large vehicles to be equipped with catalytic converters. It was reported as a success story for the European Parliament, which insisted on the introduction of higher EC standards [33]. Given the preference of several countries for stricter standards, this directive also meant that EC environmental legislation could no longer reflect the lowest common denominator among the Member States.

The 1980s saw rapid development in the commercial interest in new biotechnology techniques as well as in the evolution of Community policy for biotechnology, including regulatory policy, its research policies and its technological development. Commercial potential has shifted the focus of basic research from the public to the private sector. Since the development of many biotechnology products requires the deliberate release organisms into the environment whose genomes have been manipulated, adverse health or environmental effects remain of paramount importance to the concerned public. Furthermore, the patenting of biotechnology, and in particular the licensing arrangements for agricultural genetically modified organisms, have been at the centre of the recent controversy over health and ethical issues raised by biotechnology [34].

In 1988, "if only to avoid regulatory fragmentation of the common market" [37], the Commission introduced legislation aiming to regulate biotechnology development, at 
the level of research, industrial production and product marketing. The proposed legislative initiatives covered the contained use of genetically modified microorganisms (GMMOs), the deliberate release of genetically modified organisms (GMOs), and worker safety vis-à-vis biological agents.

In the agricultural sector, the need to reconcile free circulation of agricultural products with the need to ensure consumer protection and public health also required the harmonisation of food laws, particularly those relating to hygiene [38]. The agriculture sector has had its responsibilities clearly transferred from national governments to the EC (since its establishment). Agriculture continues to take up the largest part of the Community budget. In 1994, $49 \%$ of the Community's budget was spent on the common agricultural policy [38].

Existing and proposed EC food legislation, governs everything from additives and contaminants in food to labelling (from presentation to advertising), and from foodstuffs for particular nutritional uses to novel products that are developed through biotechnology. The beef crisis arising from cattle brain disease (BSE) has provided the most recent battleground over public health and consumer protection issues. This was partially due to the removal of border controls within the Community [38]. The crisis has intensified the debate over the type of farming Europe would like to see. It has also pointed out the importance of co-ordinating national food inspection and enforcement agencies and the need to establish a Community food inspection agency.

Overall, it may be said that the free movement of goods has led to a steady expansion of Community legislation in the fields of environment and consumer protection. Both of these are important for the harmonisation of health protection measures. The growth in legislation is characterised by political spillover in these fields. Environmental and consumer protection have been further analysed as examples of expanding protective regulatory types of policy at the Community level[30,32].

As new environmental (or consumer protection) issues emerge, some Member States will enact regulations that will be perceived by other Member States as non-tariff barriers to trade. These differences in policy making may be seen as an important feature of agenda setting in environmental (or consumer) policy for the EC. Indeed, in the case of environmental (or consumer) regulation a high-quality policy alternative may be selected from a list of options that have been legitimated in one or more of the member-countries. However, even if such environmental (or consumer) legislation is adopted, it will be difficult to implement, given the co-ordination problems that exist between Brussels and the member-countries. This apparent imbalance between policy formulation and implementation may be a continuing policy-making problem [39].

\section{Free movement of goods, working environment, and occupational health and safety policy}

Protection of health and safety in the working environment is ensured through technical regulations for products and equipment used by workers, as well as through provisions regarding worker protection in the working environment. Before the Single 
European Act came into force there were already a number of directives applicable in the field of occupational health. The first European directive was adopted in 1959 under the Treaty that established the European Atomic Energy Community (Euratom). This body was concerned with the protection of workers and the public from ionising radiation dangers. Indeed, articles 30-39 of the Euratom Treaty explicitly provided the Community with powers to establish basic standards for the protection of workers and the public against the risks relating to ionising radiation.

In the case of the Treaty establishing the European Economic Community (EEC), article 118 requires the Commission to promote co-operation between Member States in relation to a number of social policy issues. These provisions include prevention of occupational accidents and diseases as well as occupational hygiene. However, the EEC Treaty did not assign legislative powers to the Community for the implementing of the harmonisation of national occupational health measures, and more generally for national health and social policies. Against this background, it is not surprising that no progress was made in the field of harmonisation of national occupational health measures during the sixties.

The Commission, eager to move into the social policy area, came up with policy guidelines for the first Social Action Programme in the early 1970s. This programme was adopted in 1974, and among other things called for the establishment of a first Action Programme on occupational health and safety. Under this action programme (which would be based on articles 100 and 235 of the EEC Treaty) Community harmonisation would move into the area of working conditions, and the regulation of production conditions when large differences in national regulation could distort competition*. In the period up to 1988, a total of seven new directives were adopted. These directives covered issues such as safety signs, a framework directive to protect workers from exposure to chemical and other hazardous agents, and four individual directives concerned with protection against risks from vinyl chloride monomer, lead, asbestos and noise. $\dagger$

Article 118a that was introduced by the Single Act, brought occupational health and safety into formal EC competencies. Indeed, occupational health is the only area of social policy that the EC was given direct power to harmonise national measures. In addition, qualified majority voting has been a crucial factor influencing far more ambitious and wide-ranging EC legislative action than has existed ever before. We should emphasise that harmonisation based on article $118 \mathrm{a}$ provides only for directives to lay down minimum requirements, rather than ensuring a high level of health, safety, environment and consumer protection specified in article 100a. While article 118a explicitly allows Member States to enact stricter requirements, there is nothing to prevent them from lowering existing national standards down to the level detailed in Community directives.

* For the complementarity of measures concerning the regulation of products and production processes and the measures relating to workers safety and more generally working conditions see $[40,41]$.

$\dagger \quad$ For a detailed discussion about the Community activity and its implications see [42]. 
Since 1988, about twenty new directives were introduced. Some of them amended existing ones on asbestos, noise, lead and other hazardous agents. Others, previously held up by national vetoes, were adopted, and are concerned with protection against carcinogenic agents and procedures for setting exposure limits. The Framework Directive $89 / 391 / \mathrm{EEC}$ is the most significant of the directives adopted under article 118a. It applies to all sectors of activity, both public and private and lays down a series of general principles concerning:

"the prevention of occupational risks, the protection of safety and health, the elimination of risk and accident factors, the informing, consultation, participation and training of workers and their representatives as well as general guidelines for the implementation of the said principles" [43].

The individual directives (most of them related to the framework directive) introduced minimum health and safety measures concerning the following [44]:

the organisation of safety;

selection and use of a plant and machinery;

selection and use of personal protective equipment;

manual handling of loads, particularly in relation to risks of back injury to workers;

revision of safety signs directive;

work with display screen equipment;

temporary and mobile work sites;

extractive industries;

health and safety for fishing vessels;

safety in construction;

protection from risks related to exposure to chemical, physical and biological agents;

carcinogenic agents;

cadmium compounds and pesticides;

protection of pregnant workers, and workers who have recently given birth;

the organisation of working time, including those relating to night work;

protection of workers with a fixed or temporary employment relationship.

The most controversial measure of all was the directive on the organisation of working time which, among other things, sets a maximum working week of 48 hours and minimum annual leave of four weeks. The UK government expressed doubts about whether the directive on working time was appropriate for consideration under article 118A. After seeing the directive adopted by majority vote, its legality was challenged in the European Court of Justice. The final Court ruling went against the UK 
government and the directive was kept (case 84/94, the UK Government versus Council, Court Decision of 12.11.96).

The Commission can also propose occupational health and safety measures under the Protocol on Social Policy appended to the last Treaty of the European Union. This Protocol applies to all Member States of the EC, excluding the UK, and entails an agreement to implement the Community Charter of the Fundamental Social Rights of Workers. The Community Social Charter was also adopted by all Member States except the UK, in the form of declaration in 1989 [45]. In essence, the Protocol provides a second legal framework (albeit complex and controversial) for social policy development in the EC, and extends qualified majority voting to concern the working environment proposals (including health and safety), as well as working conditions [46].

Moreover, the evidence available suggests that the directives adopted by the Council have significant implications for national legal frameworks for occupational health and safety. The introduction of the directives required national laws to be created that were not previously in existence in Greece, Portugal, Spain and Ireland. They sparked controversy in Italy over whether a new health and safety Bill (intended to harmonise Italian regulations with European measures) was inferior to existing legislation [42]. In countries such as the Netherlands, Germany, France, and the UK, the enactment of these directives required amendments and additional regulations creating the need for the introduction of new interpretations to existing national legal frameworks [47].

The impact of EC legislation is not limited to the enactment of Community Directives by the national authorities. Rather, the actual impact on worker protection depends on the extent to which the legislation is enforced by national authorities. Existing evidence shows that the implementation of Community legislation follows the same patterns and meets the same obstacles as the implementation of the respective national legislations*. Much will depend on existing national politico-administrative attitudes towards the implementation of law, and the availability of trained inspectors and financial resources to ensure their enforcement. Implementation problems (as well as other issues) prompted the establishment of the European Agency for Safety and Health at Work [49]. Indeed, the development of common approaches to enforce EC occupational health and safety legislation is likely to remain within the Community policy agenda.

\section{Free movement of persons, the right of establishment, and education of health professions}

The free movement of persons is dealt with in articles 48-58 of the EEC Treaty, and can be divided into two categories: the provisions for the free movement of workers;

* Siedentopf and Ziller, for example, studied the implementation measures taken by the Member States with respect to seventeen EC directives belonging to very different policy areas and representing the wide scope of EC legislation, see [48]. 
and the right of establishment for self-employed professionals. In relation to workers, freedom of movement entails "the abolition of any discrimination based on nationality". In addition, the freedom of one Member State's nationals to establish in the territory of another entails the right to take up and pursue an activity as a selfemployed person. So, all EEC nationals should receive equality of treatment whether they are workers or self employed.

The guarantee of equal treatment does not exhaust the possibility of other obstacles to freedom, notably, in the form of differing national regulations on the training and qualifications of self-employed persons. These differing national requirements can have the practical effect of preventing the establishment of self - employed individuals, including health professions. Article 57 of the EEC Treaty provided for the Council,

"to issue directives for the mutual recognition of diplomas, certificates, and other evidence of formal qualifications".

In the case of medical and pharmaceutical professions, paragraph three of the same article states explicitly that,

"the progressive abolition of restrictions shall be dependent upon coordination of the conditions for their exercise in the various Member States."

Since the mid-1970s, the mutual recognition of diplomas (rather than the harmonisation of the content of education) has been the object of a series of Community directives on health professions. These directives are concerned with the mutual recognition of professional qualifications for doctors, nurses, dental practitioners, pharmacists and other health auxiliaries. Few doctors have made use of their free mobility possibilities in the past and few may be expected to migrate in the future. It was estimated in 1991 that less than two thousand doctors received authorisation to work in a Member State other than their own [50]. About the same is true for nurses.

\section{Free movement of persons, workers and social security}

It was quite clear to the founders of the EEC that free movement of workers (employed and self employed) would never be realised unless the social security rights of those who chose to move, were protected. Indeed the co-ordination of social security systems between Member States seemed vital in order to run the market properly. Therefore it was decided that migrant workers must be given the same treatment as those workers who remain within a single Member State throughout their lives [51].

Article 51 of the EEC Treaty implements this policy of equal treatment and reads as follows:

"The Council shall, acting unanimously on a proposal from the Commission adopt such measures in the field of social security as are necessary to provide freedom of movement of workers; to this end, it 
shall make arrangements to secure for migrant workers and their dependants:

a aggregation, for the purpose of acquiring and retaining the right to benefit and of calculating the amount of benefit, of all periods taken into account under the laws of the several countries;

b) payment of benefit to persons resident in the territories of Member States."

Article 51 can therefore be said to have placed social security on a personal rather than a territorial basis for Community purposes. Rights remain with a worker whenever he moves within the Community. Apart from altering the territorial scope of national social security systems, article 51 does not change the system in any way. It merely coordinates the operation of the prevailing national social security systems in order to ensure the protection of a migrant worker. That is to say, the Member States remain responsible for the conditions necessitating the affiliation to a social security system, the level of contributions, the range and the level of benefits provided, and the conditions for entitlement to those benefits.

The system envisaged by article 51 was first implemented in EEC regulations $3 / 58$ and $4 / 58$. These were eventually replaced by regulations $1408 / 71$ and $574 / 72$, which have been repeatedly amended and are still in force. These regulations cover the social security rights of migrant workers, migrant self-employed and their family. Stateless persons and refugees residing within the territory of one of the Member States are also covered.

The regulations cover cash benefits and benefit in kind which are paid out for the following benefits: sickness and maternity benefits, disability benefits, old-age benefits, survivors' benefits, benefits with respect to accidents at work, and occupational diseases, death grants, unemployment benefits and family benefits. There are no official definitions of these concepts. According to the case law from the Court of Justice, sickness benefits in kind refer to the provision of health care services while cash benefits refer to the income maintenance of a worker during a period of illness [52].

Although the scope of EC co-ordination in social security has been limited, the implementation of Community regulations proved to be very difficult. A fundamental criticism expressed pertains to the complexity of these regulations [53]. The European Court of Justice has delivered more than 250 judgements concerning the application and interpretation of Community rules. However, few health insurance cases have been brought to the European Court [52].

Moreover, the EEC Treaty provisions concerning social policy have provided the basis for further discussions on the harmonisation of social security standards in the Community. In spite of the harmonisation of working conditions and living standards envisioned in article 117, the Community was not given power to implement social security law in Member States. The restrained role of the Community is also represented in the measures of article 118, which requires the Commission to carry out studies, deliver opinions and arrange consultations in the social field including social 
security. Community legislation therefore remained restricted to the regulations coordinating national schemes that benefit migrant workers and migrant self employed. The only harmonisation in social security concerns three directives that were adopted in the second half of the seventies regarding the principle of equal pay for equal work between men and women (article 119).

Arguments for and against harmonising national social security systems will be mentioned briefly. Social dumping which is the process whereby capital seeks out those countries where labour costs are lowest (perhaps because employment rights are least developed). This is not a new issue. It was raised in the intergovernmental conference that established the EEC in 1957. Indeed the introduction of articles concerning social policy $(117-122)$ were mainly the result of French concerns over 'social dumping' [54]. To avoid repeating the entire debate, we will point out that fair competition in a single market is still one of the main arguments in favour of harmonisation measures in the field of social security.

The opinion which prevailed considered harmonisation of social security as unnecessary. However, social security costs represent only one element of wage and labour costs. Divergences in social security costs, therefore, may still be compensated by differences in wage and taxation levels, or labour productivity differences. Further, available infrastructures, social climate, and overall taxation schemes also determine an industry's competitive position.

At the end of the 1980 s, the decision to establish the single market gave rise to much controversy about its social consequences. The dispute focused on the fact that labour cost would acquire a special importance as a factor for improving the competitiveness between enterprises. It was once again argued that countries would decrease social security contributions in order to boost the competitiveness of their enterprises.

It was noted that the establishment of the single market would impose limitations on the government policy mechanisms (for example, government subsidies, taxes, protection, interest rates). Therefore, the only factors determining competition would be technology and labour cost. In addition, it was argued that in the countries that participate in the Exchange Rate Mechanism (ERM) of the European Monetary System (which by definition can not use monetary policy in order to improve competition) wages and labour cost would become the only variables capable of absorbing external shocks and leading to the adjustment of national economies [55].

The debate on social security has been subordinated to the narrow logic of marketintegration as a means to avoid social dumping. That is to say that social security was dealt with as a cost factor affecting competition. Aspects such as the effect of redistribution were excluded. However, social security concerns have brought about government interventions to reduce the free play of market forces. This was done in order to affect patterns of income distribution, to ensure protection, and to provide care and social services.

The Single European Act left the respective competencies of the Community institutions unchanged. The adoption of the Community Social Charter helped build fundamental social rights in Community law, and indeed encouraged harmonisation of social security rights in the Community. Although it has been accepted that the 
"construction of a dynamic and strong Europe depends on the recognition of a foundation of social rights", the Charter delegated the responsibility in almost all matters to the governments of the Member States [56].

The conditions for adopting social security legal measures remain unchanged in the Treaty on European Union, and article 118 remains pertinent to social security. Moreover, the requirement of unanimous voting in the Council is likely to thwart future adoption of measures within the Social Charter (which was appended in the last Treaty as an Agreement on Social Policy).

In view of the introduction of a common currency, the convergence criteria established by the Treaty on European Union (with regards to inflation, public debts and deficits) has sparked the most recent controversy over the future of the social security systems in the Community. Academic literature has shown the implications of the economic and monetary union for social security systems. Economic and monetary union will affect the established norms in the field of social security, industrial relations, and salary negotiations as well as fiscal and budgetary policies in general [57].

\section{Summary and conclusions}

The initial decision to create a common market did (as neofunctionalists have argued) set in motion a dynamic process of functional spillovers in the field of health legislation. Historically, it has been health considerations that justified differences in national market regulations. These differences have acted as non-tariff barriers to trade and distortions to competition. It was imperative to harmonise national legislations which represents the primary instrument of functional spillovers into fields such as medicine, environment, consumer protection as well as occupational health and safety. Health and safety legislation in these fields may also be seen as an example of reregulation that is taking place at the Community level.

Changes introduced by the Single European Act altered the institutional rules governing the Community harmonisation process. The introduction of qualified majority voting removed the ability of any single Member State to veto proposed legislation by the Commission. Thus, the process of harmonisation in all the fields mentioned above was facilitated. In addition, second readings and the co-operation procedures allowed the Parliament together with the Commission, to make amendments to Council Directives.

The Community did not attempt to directly harmonise national social and health care policies. Instead, the imperative to remove obstacles to the free movement of workers and the self employed led to spillovers, in the education of health professions as well as in the social security legislation of the Member States.

As far as the nature and the content of EC legislative initiatives in the field of medicines is concerned, we may say that the development of a single market for medicines required prior harmonisation of national criteria and procedures for the authorisation of medicines. As a result, a volume of Community legislation for ensuring health and safety of medicinal products circulating within the EC or exported 
from it was produced. In addition, a new Community system for drug approval was established in recent years. Apart from 'mutual recognition', this new system involves the establishment of a European Agency for the Evaluation of Medicinal Products, which handles central EC arrangements for the licensing of medicinal products derived from biotechnology and other innovative products.

The single market of medicines, the EC system of drug approval and other Community initiatives in patent protection, should all be seen as part of a strategy to enhance the competitive strength of the European pharmaceutical companies vis-à-vis the USA and Japanese companies. The EC has limited powers to intervene in national social security legislations regulating drug prices and reimbursement. Governments may no longer favour domestic over foreign pharmaceutical companies, but retain their powers to regulate profits, prices, and reimbursement.

The free movement of goods also led to a steady expansion of Community environmental and consumer legislation. Environment and consumer protection have become important Community regulatory areas. Disputes over proposed EC legislation usually consist of conflicting views about how to balance environment (or consumer) protection and industry interests. As new environmental (or consumer) issues emerge, some Member States will enact regulations that will be perceived by other Member States as non-tariff barriers to trade. These national legislation differences may be seen as an important feature for agenda setting in the EC. Even if this process serves to establish stricter Community-wide standards, it will be difficult to implemented changes, given the co-ordination problems between Brussels and the member countries.

Competition in a common market should not be based on differing working conditions and health and safety standards for workers. Community harmonisation moved into occupational health in the early 1970s. Indeed, occupational health was the only area of social policy that the EC was given powers to harmonise national regulations in recent years. In addition, qualified majority voting rules in the Council facilitated far more ambitious and wide-ranging EC legislative action than ever before. However, the actual impact on worker protection is limited by on the extent to which legislation is enforced by the national authorities.

Moreover, since the mid-1970s, the mutual recognition of professional qualifications has been the object of a series of Community directives on health professions. In the past, few doctors have moved to another Member State for work, and few may be expected to migrate in the future. As for social security, EC legislative action was primarily designed to promote mobility of the labour between the Member States. As a result, Community law was set up to protect migrant workers and the migrant selfemployed as well as their family members. Apart from this law, Member States have been reluctant to cede any power to the Community to harmonise national social security legislations.

The renewed attention to the internal market culminated the adoption of the Community Social Charter (in the form of a declaration) by all Member States, excluding the UK, in 1989. The Charter helped focus attention on the incorporation of social rights (including the right to social security) in Community law. However, in 
both the Single European Act Treaty and the Treaty on the European Union, conditions for the adoption of Community legal measures in the field of social security remain unchanged. In view of the common currency, the convergence criteria agreed in the last Treaty on European Union (by the Member States themselves) is likely to affect national social security policies as well as fiscal and budgetary policies in general.

1. Ingalil JM. Harmonization of social policies and social regulation in the European Community. European Journal of Political Research 1995;27(1):21-45.

2. Haas E. The uniting of Europe: political, social and economic forces, 1950-1957. Stanford: Stanford University Press, 1958, 1968.

3. Lindberg LN. The political dynamics of European Economic Integration. Stanford; Stanford University Press.

4. Webb C. Theoretical Perspectives and Problems. In: Wallace H, Wallace W and Webb C, eds. Policy Making in the European Community. London: John Wiley \& Sons, 1983.

5. Wallace W. Less than a Federation, more than a Regime: The Community as a Political System. In: Wallace H, Wallace W and Webb C, eds. Policy making in the European Community, London: John Wiley \& Sons, 1983.

6. Simon H. The study of the European Community: The Challenge to Comparative Politics, West European Politics 1994; 17(1):1-30.

7. Gehring $T$. Integrating Integration Theory: Neofunctionalism and International Regimes. Florence: European University Institute, Working Paper RSC No. 95/39, 1995.

8. Offe C. The Attribution of Public Status to Interest Groups. In: Offe C. Disorganized Capitalism. Polity Press, 1985.

9. Shackleton M. Financing the European Community. Royal Institute of International Affairs. London: Pinter Publishers, 190.

10. Walder $\mathrm{S}$. The budgetary procedure of the European Economic Community. Wien, Köln, Weimar: Bohlaus, 1992.

11. Commission des Communautés Européennes, Vade-Mecum Budgétaire,Edition 1993.

12. Hoffmann S. Obstinate or Obsolete: the fate of the nation - state and the case of Western Europe, Daedalus, 95 (Summer 1966), pp 862 - 915.

13. Moravcsik, Preferences and Power in the European Community: A Liberal Intergovernmentalist Approach, Journal of Common Market Studies, vol. 31, number 4, December 1993, pp 473 - 524.

14. Sbragia, Thinking about the European Future: The Uses of Comparison, in idem (ed), Euro-Politics, Institutions and Policymaking in the new European Community, Washington D.C: The Brookings Institution, 1992.

15. P. Kenis \& V. Schneider, The EC as an international corporate actor: Two case studies in economic diplomacy, European Journal of Political Research, number 15, 1987, pp 437 457. 
16. S. S. Andersen and K. A. Elliassen, The EC as a New Political System, in idem (eds), Making policy in Europe, London: Sage, 1993.

17. approximation of laws, Articles 100 to 102.

18. Swann D. The economics of the common market. London: Penguin Books, seventh edition 1992.

19. Jacques Pelkmans and Ad Vollebergh, The Traditional Approach to Technical Harmonization: Accomplishments and Deficiencies, in idem (eds), Coming to Grips with the Internal Market, Maastricht: European Institute for Public Administration, 1986.

20. Commission Européenne, Les Institutions de l'Union Européenne. Office des publications officielles des Communautés Européennes. Luxembourg, 1995.

21. Altenstetter C. Health Policy Regimes and the Single European Market. Journal of Health Politics, Policy and Law 1992;17(4);813-846.

22. Fernand Sauer, The European Medicines Evaluation Agency, in F.- J. Becker and C. D. Wielowski (eds), The Health Changes and Needs in Europe in 2010: "A Single Market in Medicines", proceedings of the Kangaroo Group Conference in Berlin on Martch 4th-5th, 1993

23. Granitza, The need for a European Medicines Agency, in F. -J. Becker - C. D. Wielowski (eds), The Health Changes and Needs in Europe in 2010: "A Single Market in Medicines, Proceedings of the Kangaroo Group Conference in Berlin on March 4th - 5th, Medical Trends, 1993.

24. Elias Mossialos, Panos Kavanos and Brian Abel - Smith, Policy options for Pharmaceutical Research and Development in the European Community, The European Institute, LSE Health, Occasional Paper in Health Policy No 1, November 1993.

25. Peter. de Wolf, The Pharmaceutical Industry: Towards One Single Market? in H. W. de Jong, The Structure of European Industry, Dordrecht: Kluwer Academic Publishers, Third revised edition, 1993.

26. See the analysis of Peter de Wolf and Graham Chambers and Paul John Belcher, The Consumption of Medicines in the European Union, in E. Mossialos, C. Ranos, B. Abel Smith (eds), Cost Containment, Pricing and Financing of Pharmaceuticals in the European Community: The Policy - Makers' View, LSE Health and Pharmetrica S. A, 1994.

27. See F. - J. Becker, The European Pharmaceutical Industry in the Internal Market, and R. Buscher, The Internal Market for Medicines is (almost) completed, in F.- J.Becker and C. D. Wirlowski (eds), the Health Changes and Needs in Europe in 2010: "A Single Market in Medicines", Proceedings of the Kangaroo Group Conference in Berlin March 4th - 5th, Medical Trends, 1993.

28. See E. Mossialos , C. Ranos amd B. A. Smith (Eds), Cost Containment, Pricing and Financing of Pharmaceuticals in the European Community: The Policy - Makers' View, LSE Health and Pharmetrica S. A., 1994.

29. D. Taylor, Prescribing in Europe - forces for change, BMJ, Vol. 34: 239 - 42, 1992.

30. Judge D, Earnshaw D, Cowan N. Ripples or waves: the European Parliament in the European Community policy process. Journal of European Public Policy 1994;1:27-52. 
31. Vogel D. The Making of EC Environmental Policy. In: Andersen SS, Elliassen KA, eds. Making Policy in Europe: The Europeification of National Policy - Making, London: Sage, 1993.

32. M. Pollack, Creeping Competence: The expanding Agenda of the European Community, Journal of Public Policy, Vol. 14, 1994, pp 95 - 145.

33. George Tsebelis, The Power of the European Parliament as a Conditional Agenda Setter, American Political Science Review, Vol. 88, No 1, March 1994.

34. European Voice, Survey Health: Campaign to strengthen biotechnology industry is the focus of ethical and environmental debate, 27 June - 3 July 1996.

35. Mark F. Cantley, Public perception, public policy, the public interest and public information: the evolution of policy for biotechnology in the European Community in John Durant (ed.), Biotechnology in public, A review of recent research, London: Science Museum, 1992.

36. See, European Parliament, Public Health and Consumer Protection: Activities of the Environment, Public Health and Consumer Protection 1989 - 1994, Working Paper - 7, Luxembourg: Directorate General for Research, 1994.

37. European Commission's Publication Unit, The Budget of the European Union, Luxembourg: Office for Official Publications of the European Communities, 1994

38. Nathalie de Grove - Valdeyron, Libre Circulation et Protection de la Santé Publique: La Crise de "La Vache Folle", Revue du Marché commun et de l'Union Européenne, n 403, decembre 1996, pages $759-767$.

39. Guy Peters, Agenda-Setting in the European Community, Journal of European Public Policy 1:1 June 1994, pp 9-26.

40. Daniel Lejeune, Securité au travail et normes européennes, in Revuc Francaise des Affaires Sociales, Novembre 1989.

41. Olivier Dutheillet de Lamothe, Hygiene, sécurité at santé au travail en Europe, in Revue Francaise des Affaires Sociales, Novembre 1989.

42. Phil James, Occupational Health and Safety, in Michael Gold, The Social Dimension:Employment Policy in the European Community, Macmillan Press, 1993.

43. Council Directive $89 / 391 / \mathrm{EEC}$ on the introduction of measures to encourage improvements in safety and health of workers at work, OJ No L $183 / 2,29.6 .89 \ldots$

44. European Commission, Europe for safety and health at work, Social Europe 3/93, Luxembourg, Office for Official Publications of the European Communities, 1994.

45. Commission of the European Communities, "Community Charter of the Fundamental Social Rights for Workers", Luxembourg: Office for Official Publications of the EC, 1990.

46. Treaty on European Union, Agreement on Social Policy, Article 2.1 and 2. 2. 
47. See Commission of the European Communities, Second Report on the application of the Community Charter of the Fundamental Social Rights of Workers, Social Europe, Supplement 1/93, Luxembourg: Office for Official Publications of the European Communities, 1993.

48. H. Siedentopf and J. Ziller, Making European Policies Work, The Implementation of Community Legislation in the Member States, Vol. I, Comparative Syntheses, European Institute of Public Administration, London: Sage, 1988.

49. Regulation 2064, OJ J216, 1994.

50. See L. Dubouis, L' Europe de la sante, Annales des droit de Louvain, 1991, pp 143-164, and European Public Health Alliance, Libre Circulation des Professionnels dela Sante, Dossier d' Information No.6, Avril 1995.

51. Philippa Watson, Social Security Law of the European Communities, Mansell Publishing, 1980.

52. Commission of the EC, Social Security for persons moving within the Community, Social Europe, 3/92, Luxembourg: Office for Official Publications of the EC, 1992.

53. Danny Pieters and Steven Vansteenkiste, Social Security in the European Community: Co-ordination, Harmonization or Thirteenth State?, International Journal of Public Administration, 18(10), pp $1639-1672$

54. Lammy Betten, Prospects for a Social Policy in the European Community and its impact on the functioning of the European Social Charter, in Lammy Betten (ed), The Future of European Social Policy, Deventer - Boston: Kluwer Law and Taxation Publishers, 1991.

55. W. J. van der Eijk et al, Europe 1992 and the consequences for health care, A first survey and discussion paper for management and board of the National Hospital Association of the Netherlands and the National Hospital Institute, Utrecht, 1988.

56. M. Theofilatou and R. Leidl, Public Health Policy and Health Services Research in the European Union, in U. Laaser, E. de Leeuw, and Christiane Stock (ed), Scientific Foundations for a Public Health Policy in Europe, Weinheim und Munchen: Juventa Verlag, 1995.

57. Observatoire Social Europeenne, Union Economique et Monetaire et Protection Sociale, Working Paper No 11, Mai 1995.

Acknowledgment. The authors are grateful to the following persons for their helpful comments on the earlier versions of this paper: Jan van der Made, Kostas Koikas, Ab Landerweerd and Tassos Kanatouris. We also wish to thank Nikos Papadimitriou responsible of the Greek library of the Commission's translation service for his invaluable help and Jan van Emmerik for his assistance in editing the manuscript. 


\section{6}

Social Security \& Health (care) Systems: from Harmonisation \&

Convergence to the Reality of Monetary Union 


\section{Introduction}

We emphasised in chapter three that despite a significant upward trend in the 1980s, the Community budget has always remained much smaller than national budgets. At present it is less than 1,2 percent of the GDP in the Community and less than 2,5 per cent of the total public expenditure of the Member States. The budget does not include any provision for social security nor for more programmes aiming at interpersonal redistribution of income. The common agricultural policy (CAP) is an exception. This policy primarily relies on price regulation to maintain farm incomes. In that sense, CAP may be considered part of a "welfare state of farmers".

The doubling of the structural funds, which was decided in 1988, was intended to reduce regional disparities across the Community. It did not aim at a reduction of individual differences between countries, at least not in a direct sense. As Majone pointed out, Community redistributive programmes are generally ineffective if judged by the criteria of social security spending i.e. social insurance and socialised medicine 1 .

In the previous chapter we also pointed out that topics relating to fiscal provisions and the rights and interests of employed persons were explicitly excluded from the harmonisation process of the single market i.e. articles 100 and $100 \mathrm{a}$.

Occupational health and safety were the only areas of social policy where the EC was given power to harmonise national legislation. As a consequence, harmonisation moved into the area of working conditions where large differences in national legislation could distort competition.

As to the social security regime for migrant workers (articles 48-51), Community regulations merely co-ordinate the operation of the national social security systems in order to facilitate free movement of workers and to provide appropriate social security cover for migrant workers, whether salaried employees or self employed, and their dependants. Issues of harmonisation and establishment of Community social security rights have been within the treaties since the establishment of the Community (article 117), but only in unspecific terms. Harmonisation was proposed but the Community was not given power to set common legislation nor to develop any form of financing mechanisms in social security and health care.

After a brief overview of the treaty provisions on social policy and historical interpretations of the term "harmonisation" in article 117, the first part of this chapter concentrates on recent discussions and initiatives concerned with harmonisation and/or convergence of social security systems, including health care. These discussions and initiatives took place within the context of EC social policy, in particular in the Community Social Charter, and referred to the existing social security (or social protection) rights, policies and systems in the Member States. They did not specifically focus upon health care issues.

We will analyse the Community's institutional structure for dealing with these issues and the difficulties in defining them in such a wide field. This analysis will help in 
understanding the problems facing the Community in developing a more active role in health (care) policy. For example, before focusing on the Community public health provisions (articles 129 of the Maastrict Treaty and 152 of the Amsterdam Treaty) it may help to better understand why issues relevant to health care rights, health care financing, organisation and delivery, were explicitly excluded.

The Single European Act, which committed the EC to complete the single market, revitalised the debate on the role of the Community in social (and industrial) relations. Discussions were focused on whether the single market mechanisms were sufficient to protect the social and economic rights of workers, and whether EC social regulation was required and, if so, in which way.

As a response to these concerns, the Community Social Charter was adopted by the Member States with the exception of the United Kingdom, in the form of declaration in 1989. It focused on the establishment of common or minimum standards of social security, including health care. Some fundamental questions in this respect were: to what extent should workers' rights be protected in the single market? If they should be protected, which rights should be covered? How should they be covered - through legislation, agreement, or a combination of both?

The Social Charter provided, for the first time, an institutional framework to discuss issues of social security among the Council, the Commission and the social partners. The Social Charter was annexed to the Social Protocol as an Agreement on social policy. The Protocol entitled the Member States, with the exception of the United Kingdom, to continue along the path laid down in the Social Charter.

We argue that this institutional framework is not a suitably visible forum for debating the establishment of Community social security rights. Rather, it reflects fairly accurately the disagreements characterising the development of active Community intervention in social security, including the health (care) sector and also demonstrates the lack of willingness (and determination) of discontented interest groups to carry their appeal to a wider forum.

Meanwhile, the Maastricht treaty established the provisions for Economic and Monetary Union (EMU) and required a set of strict economic conditions from every state in order to participate fully in EMU by January 1, 1999. States not meeting the cut-off levels for inflation, interest rates, budget deficits, and exchange rate stability would not enter the third and final phase in the formation of EMU i.e. the European Central Bank, the fixing of exchange rates and the substitution of a single currency for separate national currencies.

In the face of great disparities in economic development among countries (and labour costs) and in the absence of a federal taxation system and budget, governments used these nominal criteria to enforce price stability and budgetary discipline. The effects of EMU and the associated limitations for budgetary policies on social security have sparked the most recent controversy over the future of social security systems: How will EMU affect social security? Does it represent a fundamentally new context for questions in relation to a Community role in social security? If it does, what can the Community do within this context - through legislative acts or new spending 
commitments? And, what can the social partners and, notably, trade unions, do in the context of the Social Protocol or the Social Agreement?

The second part of this chapter briefly reviews reports and studies concerned directly or indirectly with the impact of EMU on social security and health care. Our intention is to get to grips with the arguments of this recent debate rather than to provide answers. Studies and reports carried out by economists are concerned with the impact of monetary union on government budgetary policies and public policies and with its impact upon what may be considered the public sector, or provision of public goods in Europe. That is, they do not examine the effects of monetary union on social security and/or health care programmes as such, referring to these areas only when they represent important items in government budgets.

We use alternatively the terms "social protection" and "social security" to refer to the full range of modern welfare functions covering old age pensions, sickness, invaliditydisability, occupational injury benefits, family and unemployment benefits. There is a general agreement that social protection is primarily concerned with interpersonal redistribution of income and hence solidarity. Applied to health, "solidarity", according to the Discursive Dictionary of Health Care published by the US House of Representatives (1976), is a term used mainly in European countries to denote compulsory risk-pooling in a public health insurance scheme, with payment for health care based on ability to pay and the offer of health care based on medical need ${ }^{2}$.

\subsection{The Social Provisions in the EC Treaties}

Some of the provisions concerning social policy require more detailed attention because of their relevance to health protection. The original provisions concerning social policy in the EEC treaty included the social provisions (articles 117-122) and the provisions for the European Social Fund (articles 123-128). The Single European Act (1987) introduced only a few social policy provisions to the main body of the treaty. These can hardly be referred to as a breakthrough from the social point of view. Nevertheless, the changes were substantial in the field of occupational health and safety (118a) and provided for the institutionalisation of social dialogue with the Euroorganisations of labour and industry (article $118 \mathrm{~b}$ ). When the Maastricht treaty came into force in 1993, Title III on Social Policy became Title VIII of Part Three of the EC Treaty ('Community Policies') entitled "Social Policy, Vocational Training and Youth". The Maastricht Treaty left the main provisions relating to social policy relatively unchanged and only introduced procedural changes for the European Social Fund (article 125) and new provisions on vocational training.

In fact, according to article 117 , the primary objective of social policy remained fairly the same since the establishment of the Community. It is worth quoting this article in full:

"Member States agree upon the need to promote working and living conditions and an improved standard of living for workers, so as to make possible their harmonisation while the improvement is being maintained. They believe that such a development will ensue not only 
from the functioning from the common market, which will favour the harmonisation of social systems, but also from the procedures provided for in this Treaty and from the approximation of the provisions laid down by law, regulation or administrative action".

In spite of the harmonisation envisioned in article 117, the Community was not given power to set up common or minimum social security standards or to develop some form of financial solidarity fund at the European level. The restrained role of the Community is represented in article 118 , which enabled the Commission to only make studies, deliver opinions, and arrange consultations in relation to various matters in the social field, including social security.

Article 118 remained unchanged in the main body of the Maastricht treaty in the area of social policy. In the Maastricht Treaty, social security was referred to as a matter of common measures to be adopted unanimously by the Council in article 121, but this explicitly concerned the measures for migrant workers (free movement of persons, articles 48 - 51). So far, the only harmonised legal measures in social security - three directives - have been based upon article 119 , which referred to the principle of equal pay for equal work between men and women.

Finally, a reference should be made to the policy responses to major health problems, which culminated in the inclusion of article 129 on public health. Since the mid-1980s policy responses to public health problems in the context of social policy include "Europe against cancer", "Europe against AIDS" and activities concerning drug addiction. Activities cover prevention, training of personnel employed in health care, medical and health research. In the following chapter, we examine the content of public health activities and the political significance of article 129. Here we concentrate on social security and next we discuss how the term harmonisation has been interpreted by various actors involved in this discussion since the inception of the $\mathrm{EC}$ in the 1950s.

\subsection{Harmonisation of the social security systems: Elements of a heated debate}

Various commentators have pointed out that the ambiguity of the term harmonisation in article 117 indicates the reluctance of governments to give the Community more power than mere co-ordination of national social security systems for the coverage of migrant workers and their families. A more important Community role would raise issues of Community-revenue and spending commitments. Bargaining on budgetary issues has been permanently adversarial in character since the establishment of the Community in the 1950s. It was always easier to reach agreement on the internal market, trade, regulation, and monetary union than on precise budgetary commitments to tackle their distributional or redistributional repercussions for social welfare. The question of who benefits from what and to what extent, has always raised political dilemmas and conflicts ${ }^{3}$.

Until now harmonisation and the establishment of Community social security rights remained the subject of discussions, studies and exchanges of information at the 
Community level, most of them initiated by the Commission on the basis of article 118. The discussions did not only involve the Commission and the governments, but also the European Parliament, employers, trade unions, the Economic and Social Committee and others. ${ }^{4}$

This debate raised a number of topics relating to national social security systems, for example: the percentage of the population covered; the methods of financing (i.e. obligatory contributions related to earnings or taxation related to personal income); the fields of application; the eligibility rules that govern access to benefits, (i.e. the extent to which eligibility rests on the degree of prior work performance); the duration and the level of those benefits; the benefits for those who have no income.

The conclusion reached was that harmonisation of social security systems, in terms of total unification of the social security protection for all citizens of all EC Member States, was not acceptable or politically feasible. Even Commission officials in favour of Community intervention in social security, found that the differences in financing, organisation, fields of application et cetera were great ${ }^{5}$.

Above all, it turned out that total unification was politically undesirable. Governments are in control of something approaching 50 per cent of the total national budget and are reluctant to loose control of their own spending. National social security administrations and trade unions are reluctant as well. They know that the lines of accountability lead directly to their governments whilst the democratic legitimacy and accountability of Community institutions is still disputed. For understandable reasons, trade unions also want to protect the particular achievements of individual national systems. To use the words of Hoffmann almost thirty years ago,

"those who argue in favour of a more integrated world, either under more centralised power or through various networks of regional or functional agencies, tend to forget Auguste Comte's old maxim that on ne detruit que ce qu'on remplace: the new formula will have to provide not only world order, but also the kind of social organisation in which leaders, elites and citizens feel at home. There is currently no agreement on what such formula will be. ${ }^{\text {th }}$.

Perhaps, the lack of solidarity and the sense of a European citizenship should be considered the most important obstacles to a widening of the agenda of European integration to include social security. Solidarity is a European term associated with interpersonal redistribution of income, but it takes different configurations as a part of the fabric of the nation-state. We should not forget that any form of solidarity at the Community level requires that there is a willingness on the part of citizens throughout the Community to accept cross-border transfers for the well-being of fellow citizens in other Member States.

Why then have there been social provisions in the Treaties since the establishment of the Community? The French concerns about social dumping - the process whereby capital seeks out those countries where labour costs are lowest, perhaps because of lower wage, social costs and labour conditions- to a large extent explain why the social provisions were introduced in the founding treaty of the $\mathrm{EC}^{7}$. The question of social 
dumping remained a central element of the debate. Concerns have constantly been expressed, especially after the Community enlargement to Greece, Portugal and Spain in the 1980s. The countries in the centre-north of the Community feared that lower labour costs in the south would have negative effects on the competitiveness of their firms and consequently would lead to lowering of their social standards. But this fear was not generally recognised on the argument that social security costs represent only one element of wage and total labour costs. Divergence in social security costs across countries, therefore, does not necessarily affect competition. Hence, they do not justify Community harmonisation of national social security systems ${ }^{8}$. Total labour costs, or more accurately, the labour costs per product unit (productivity of the workers), should be considered. Even then the infrastructures, tax, energy, capital costs, and many other factors would have to be examined.

Supporters of this social protectionist line of reasoning would give much greater scope to Community intervention not so much in terms of social rights, but in terms of promoting development in the less developed regions of the EC. Within the current financial perspective, the structural and cohesion funds and the trans-European networks may be seen as the first hesitant steps towards this developmentalist approach.

The problem of unemployment has become a more important issue than the harmonisation of national social security or health (care) systems during recent years. The unemployment rate reached on average 11 percent in the Community as a whole in 1996, varying from 22 percent in Spain, 16 percent in Finland, and 12 percent in Italy and France to 6,4 percent in the Netherlands and 5,3 percent in Austria. Young people and women were particularly affected. Europe's employment rate - the proportion of its population of working age that is in work - has fallen over the past two decades to 55,3 percent in 1996 and is the lowest of the industrialised world ${ }^{9}$. The steady increase in unemployment over the last twenty years led the social security systems into permanent financial crises in all countries.

"The one and only reason is unemployment" stated the Commission in explaining why it published its White Paper on "Growth, Competitiveness and Employment" in 1993 10. The White Paper called for Community investment in infrastructures and in particular, Trans-European telecommunications, transport and energy networks. In aiming to reduce unemployment, it called for reduction in the statutory contributions of unskilled and semi-skilled workers and proposed alternative financing methods of social security. For example, environmental taxes, taxes on capital, and taxes on consumption on health damaging products such as tobacco and alcohol.

Health services generate employment for a great number of professions and are a real source of job creation especially for women ${ }^{11}$. The White Paper emphasised this employment-creation aspect of health services, by including home help for the elderly and health (care) services in its list of sectors creating new jobs.

Did those who believed that there was a need for the incorporation of fundamental social rights, including social security rights in Community law and financing of social and health (care) programmes, lose their arguments? Nothing is less certain. In the 
light of the Single European Act and the 1992 project, voices were increasingly heard that market integration might not only have substantial territorial and sectoral effects, but also substantial distributional consequences between and within social classes or groups of citizens. The main argument was that the single market intensifies economic pressures which inevitably lead to corporate restructuring - particularly mergers and take-overs amongst the most successful enterprises and closures as well as redundancies amongst the least successful ${ }^{12}$. Concrete examples from the recent past prove that some people exaggerate the lack of competitiveness and the need to face competition from low wage countries in order to justify changes in, for instance, the employers' contributions to social security. ${ }^{13}$ Even those who neglected to link between competition and social wages, found it difficult to ignore the effects that economic integration might have on the national social security systems. The voices of those calling for an assessment of the effects of the European Monetary Union (EMU) and especially the convergence criteria of the Maastricht treaty (with regards to inflation, public debts and public deficit) were increasingly heard.

The pressures to reconsider the European social order have increased in recent years and the term "social" has undergone a partial change of meaning. Governments, Community officials, political parties and the Euro-organisations of labour and industry responded in both pragmatic and symbolic ways to the social consequences of economic integration. Pragmatically they reformed structural and cohesion funds. Symbolically they agreed principles that relate to fundamental social rights and i.e. the Social Charter took a more concrete form and was attached to the Maastricht treaty as the Agreement on Social Policy. In empirical terms, the recent discussions about convergence in the regulation of social security systems, the setting up of Community standards and the establishment of a Community solidarity fund were formulated in this framework. The following sections review these developments and examine their significance.

\subsection{From the Social Charter to the Convergence of Social Protection Objectives and Policies}

In the context of moves towards the single market programme, the Belgian Presidency of the Council of Ministers proposed the adoption of an EC-wide platform to revitalise the social rights debate ${ }^{14}$. The Community Social Charter of the Fundamental Social Rights of Workers was adopted in the form of a declaration by the governments of the Member States with the exception of the United Kingdom in 1989. It was intended to lay a foundation for the Community social dimension by establishing a set of rights systematically applicable to all workers and to certain groups of marginalised people across all Member States. The governments declared that it was their responsibility,

"to guarantee the fundamental social rights in this Charter in accordance with national practices, notably, through legislative measures or collective agreements".

They invited the Commission to set out a Social Action Programme to accompany it ${ }^{15}$. 
The Social Charter contains the following headings:

Freedom of movement

Employment and remuneration,

Improvement of working and living conditions,

Social protection,

Freedom of association and collective bargaining,

Vocational training

Equal treatment for men and women,

Information, consultation and participation of workers

Health protection and safety at the workplace,

Protection of children, adolescents and elderly persons

Disabled persons

Rights concern primarily labour relations, with four of them referring to social protection. Most of the social rights in the Community Social Charter are guaranteed by existing constitutional provisions and legislation of the Member States, international labour conventions (International Labour Organisation) and also by conventions concluded in the framework of the Council of Europe (European Social Charter of 1961, European Code of Social Security of 1964). To the extent that not all international and European conventions are binding on the Member States, the Social Charter represents a new Community "legal safety net" for the transposition of international conventions to national law. For example, the European Court of Justice, without explicit powers to do so, has found ways of developing general principles of Community law, including fundamental social rights ${ }^{16}$.

Overall, the Social Charter sparked off a double controversy: debate raged both round the substantive issues - the merits and demerits of individual measures - and the procedural issues which hinder their implementation. For example, its supporters maintained that the chances of implementation were severely limited if unanimous voting on the Council of Ministers was required to adopt the majority of its proposals. They opposed the argument that majority voting should be extended to cover all social policy initiatives, including social protection, not just health and safety as was then the case.

Although it was recognised that,

"the construction of a dynamic and strong Europe depends on the recognition of a foundation of social rights","

the Charter delegated the socio-political responsibility in almost all matters to the governments of the Member States. It did not allow for the adoption of binding social security measures nor for the establishment of Community social security rights. 
The Commission has proposed 47 individual measures in its Social Action programme relating to the Social Charter. The proposals included mainly updates of existing measures (redundancies directive and the 1983 asbestos directive); incorporation of measures already in progress and revamping of certain deadlocked measures (such as several of those under the headings labour market that relate to employment creation, employment contracts, vocational training, information and consultation of workers or the European Work Councils within EC scale companies); and certain new measures (such as those concerning the social protection of "atypical" workers, the organisation of work time, maternity leave and health and safety of workers) ${ }^{18}$.

The initiatives in the field of social security drawn up to date to achieve the objectives set out in the Social Charter consist merely of non-binding measures (i.e. recommendations). The Commission published two recommendations in 1991 that were both adopted by the Council in 1992. The first recommendation defines a common principle according to which a general right to sufficient resources and benefits should be guaranteed within the social protection system of each member state 19. The second recommendation sets out the objectives that each national social security system should pursue and advocates the establishment of a monitoring system on a Community level to ensure that this is achieved ${ }^{20}$. According to the second recommendation on the convergence of social protection objectives and policies, there can be no question of harmonising the national arrangements concerning the organisation and financing of social protection. Financing and organisation of social protection systems, including health care systems, remain the responsibility of each Member State. This particularly applies to the relative proportions of obligatory and supplementary protection resulting from agreements between the social partners in each member state. The following health policy objectives have been agreed in order to serve as common policy reference:

to ensure equal access to health care and illness prevention;

to maintain and where necessary develop a high quality health care system geared to greater prevention, scientific progress, chronic illnesses and elderly dependants;

to organise the rehabilitation and reintegration of convalescents;

to provide workers who are off work due to illness with benefits equivalent to the major part of their previous earnings.

The 1992 recommendation on convergence set in motion a process of monitoring and data collection at Community level. The Commission set up a group of experts to report on the implementation of this recommendation and published its first report on Social Protection in Europe in 1994. There is also the monitoring group MISSOC (Mutual Information System on Social Protection) which consists of national representatives from ministries and authorities responsible for social protection who also supply the data. As its name implies, MISSOC serves to exchange information on changes in social security laws and levels of benefits ${ }^{21}$. In addition, the Community, through Eurostat, has a system for analysing and comparing national social protection 
expenditures and receipts called ESSPROS (European System of Integrated Social Protection Statistics).

In the meantime, arguments were increasingly heard for the inclusion of fundamental social rights in the legal system of the Community, i.e. in the treaty, and not to leave them in the form of declared principles ${ }^{22}$. The need for common reference points was considered to be sufficient reason for their inclusion which would bring a different way of looking at integration without necessarily implying any particular redistribution of competence between the Community and national authorities. The choice of levels and forms of action could still remain largely open. Nevertheless, it would bring meaning to Community social policy.

In essence, the formal affirmation of social rights in the legal system would bring out the dual dimension inherent in any fundamental right or principle: both a limit to power and a goal imposed on power. It would embody both the wish to fix limits that may not be infringed and the wish to give public authorities, national or European, objectives to be achieved. In short, the term convergence would gain in consistency and legitimacy if was measured against the yardstick of these fundamental rights and objectives.

In the context of these discussions, the question of possible financing mechanisms was raised. The question of how to compare benefits in different countries also became very important. Such a comparison would be the basis for any system that tried to establish common standards. Belgian scholars, Dispersyn and his colleagues, elaborated the "social security snake" system which is analogous to the "European monetary snake", a precursor of the European Monetary System in the $1970 \mathrm{~s}^{23}$. In this system, the levels of social security benefits in different member countries would have to be constantly measured and compared to the average of social protection in the Community. A certain maximum deviation above and below the average level would be agreed in common with all other countries. Each significant deviation from these agreed limits would result in a consultation procedure leading to intervention. States, which deviated above the maximum agreed level of benefits, might be asked to contribute to a European Social Security Fund. Conversely, states, which deviated below the agreed minimum level of benefits, might be allowed subsidies from the Fund. An increased disparity in relation to the average would start the consultation procedure. This method would apply globally to the social security system or to any particular branch of it. The application of this system implies that care should be taken that Community subsidies will only be given if the Member States concerned make a corresponding effort to bring their standards up. Care should also be taken that in the long run the minimum agreed levels would not become the total benefits particularly in states with a well-developed social security system. One can imagine how difficult it would be to set up such a system. It would entail financial arrangements and budgetary negotiations, including automatic and regular payments from member countries with higher level of benefits to member countries deviating from the minimum agreed levels.

A new Community social security system was proposed by other Belgian scholars, Pieters and his colleagues. This proposal was based on the Community social security 
regime for migrant workers which co-ordinates national systems in order to facilitate free movement of workers. According to Pieters et al, the twelve social security systems as they were then, would remain intact, but, in addition, a "Thirteenth State" as they called it, would be introduced, i.e. the Community itself, to provide social security for intra-Community migrants ${ }^{24}$. The "thirteenth state" would be offered to migrants as an alternative to the current highly complex regulations that govern the entitlements of those who move between national jurisdictions. Should it be introduced, it must offer a high level of protection for every risk - which would increase the favourable influence over migrant workers. At a later stage the system may be opened to other categories of people on the basis of collective agreements. The financing of the system should, in principle, be based fully on employers' and employees' contributions ${ }^{25}$.

Finally, less comprehensive proposals in social security have mainly focused on the establishment of a Community insurance fund for unemployment. They were introduced as part of the work of experts dealing with issues of monetary union in the union, the introduction of the single currency in most of the current Member States. We will turn to these proposals in section 4 , looking at the changes that monetary union stimulates and how they touch on social security. In the following section, we discuss the inclusion of the Social Charter as a Social Protocol and Social Policy Agreement in the Maastricht Treaty and we look at the change it brings for Community intervention in social security.

\subsection{The Social Protocol and the Social Policy Agreement}

During the period of negotiations concerning the Maastricht treaty, including its ratification process in the Member States, the Social Charter and the Action Programme came to symbolise either all that was good or all that was bad in the harmonisation of social and labour policy in the EC. Opinion about the Social Charter seemed to polarise between the neoliberal and the social protectionist coalitions; between trade unions and employers; between Socialists, Christian Democrats and "free market" Conservatives; and even between observers and commentators in countries with labour policies based on statutory frameworks and countries based predominantly on voluntaristic frameworks (notably, the UK) ${ }^{26}$.

A Protocol on social policy was finally included in the treaty, which concerned all Member States with the exception of the United Kingdom. The Protocol states that the eleven "have adopted among themselves" an Agreement to continue along the path laid down in the 1989 Social Charter and that the contracting parties, including of course the UK,

"... agree to authorise those eleven Member States to have resource to the institutions, procedures and mechanisms of the Treaty for the purposes of taking among themselves and applying as far as they are concerned the necessary decisions". 
The Social Charter was annexed to this Protocol as an "Agreement on social policy reached between 11 Member States with the exception of the United Kingdom" ${ }^{\prime 27}$.

In purely legal terms, then, the Social Policy Agreement does not replace the existing social policy provisions in the main body of the EC treaty that were discussed in section 3.1. As a result, there has been considerable debate among scholars as to the legal status of the Social Protocol and Agreement. Curtin stated,

"We have difficulty disagreeing with the statement that lawyers may, after all, be better equipped than politicians for the kind of work the European integration process involves" 28.

We may eventually consider that two legal frameworks for Community social policy exist. This situation perfectly reflects the great dispute pertaining to social policy matters that could, in the future, lead to further disputes within the Social Policy Agreement.

The following areas are covered by the Agreement on Social Policy:

Improvement of the working environment, particularly with regard to workers' health and safety; working conditions; information and consultation of workers; equality between men and women with regard to labour market opportunities and treatment at work; and the integration of persons excluded from the labour market (article 2).

Social security and social protection of workers; protection of workers where their employment contract is terminated; representation and collective defence of the interests of workers; conditions of employment for non EC nationals; financial contributions for promotion of employment and job - creation (article 3)

The areas that are explicitly excluded from this Agreement pertain to matters that relate to pay, the right of association, the right to strike or the right to impose lock-outs (article 4, paragraph 6).

The Council may adopt directives on the first group of items through the co-operation procedure, which entails a qualified majority vote in the Council. This procedural amendment represents a significant extension of EC's competencies over the items listed, all of which, except the working environment and health and safety, previously required unanimous vote by the Council.

Unanimous vote by the Council is required to adopt measures on items listed in the second group. Although the requirement of unanimous voting is likely to thwart the adoption of legal measures in social security, the Community is given power to legislate in social security matters. In other words, the Social Policy Agreement offers a formal institutional framework to discuss social security issues.

Furthermore, the Agreement on social policy assigns a key role to the social partners in the policy the negotiation, agreement and implementation of the social policy. In article 3, the Commission must consult management and labour "before submitting proposals in the social policy field" (paragraph 3 ). This requirement gives employers' organisations and trade unions a formal, consultative role at the very earliest phases of decision making. 
Article 4 declares that,

“... should management and labour so desire, the dialogue between them at Community level may lead to contractual relations, including agreements".

These agreements can be implemented either

"in accordance with the procedures and practices specific to management and labour and the Member States or in matters covered by article 2, at the joint request of the signatory parties, by a Council decision on a proposal from the Commission".

The Council acts on a qualified majority on agreements which cover the items referred to in the first group, unless the agreement covers issues referred to in the second group, including social security, in which case unanimity is required.

The implications of the Social Protocol and Agreement for the future of Community intervention in social policy, and social security in particular, are open to interpretation. According to Lange,

"under the decision rules of the protocol there is distinctly less opportunity for cheap talk..With the disappearance of the opportunities for cheap talk, the growing pressures on the commission for progress on social policy, and the Maastricht social policy protocol, more intervention at the European level seems likely ${ }^{\text {,29. }}$.

The impact of the Social Protocol and Agreement procedure will, in practice, be mediated by the activities of the Council, the Commission and the social partners, the UNICE (for industrial and employers' confederations in Europe), the ETUC (for the confederations of trade unions in Europe) and the CEEP (for public enterprises). In the long term, it is difficult to predict what the outcome of these negotiations will be.

In the short term, the provisions can bring certain social legislation into place. The first directive to be agreed on the basis of the Protocol procedure in 1994 concerned information and consultation for workers or the European Work Councils and was followed by the Parental Leave Agreement, reached by social partners in $1995^{30}$. However, given the limited financial perspectives of the Community and the lack of authority to use fiscal policy, there is little the Community can promise labour for its co-operation ${ }^{31}$.

Following the developments, the Commission and the DGV (responsible for employment, industrial affairs and social affairs) in particular, presented its discussion document or "Green Paper" aiming to launch a wide-ranging debate on the future of social policy including social protection in the Community in $1993^{32}$. The green paper addressed new issues such as European citizenship and its social dimension and pointed to the growing public concern that the net impact of the integration process could be a levelling-down of social standards. It pointed to: inter-relations between social, employment and economic policies; the need for developing a consensus around these issues; and notably, the efforts required by the Member States and people 
themselves to arrive at consensus for a model of sustainable development that combines economic dynamism with social progress.

The paper further addressed some possibilities for new policies formulated, without comment, in the form of questions in a single list at the end. The section on the single market and the free movement of people discussed the cumbersome administrative procedures facing people who exercise the right to free movement. It asked, among other questions, whether equal treatment arising from the free movement of people should be extended to all Community citizens residents in a Member State to include, in particular, social and tax advantages (students, pensioners, etc.). This question might ultimately imply a Community role in setting levels of welfare benefits.

The questions on the convergence of social policies are notably found in the section concerning the social transition to economic and monetary union (EMU):

“... to what extent will EMU also require a more active social policy?

Could the Union issue recommendations in this process of economic and social convergence, after due consultation with all national authorities concerned and the social partners, with a view to making sure that the process of economic integration does indeed contribute to its most basic objectives as defined in Article 2 of the Maastricht Treaty?

Should the Union promote convergence of social policies alongside convergence of economic policies through: the definition of common objectives and monitoring (e.g. on the same basis as convergence of social protection policies and objectives)?;

possible recommendations on important economic issues, e.g. in preventing social dumping?; monitoring procedures for social policy in the transition towards EMU?; the strong involvement of the social partners in these procedures?; joint discussions of the national authorities responsible for economic affairs and for social policy?"33.

The concrete proposals of the Commission came in the "White Paper" on European Social Policy in 1994, which covers the period from 1995 to $1999^{34}$. The paper did not propose a new legislative programme. It concluded that the strategy of the Commission is to focus on the implementation of existing social legislation. As to the co-ordination of social security for persons moving within the Community, a wideranging "technical" revision and restructuring in order to simplify the existing rules was proposed. With regard to the convergence of social protection policies, the paper linked the convergence process with the social transition to EMU. The possible impact of EMU on social security was not, however, assessed.

Furthermore, the paper said that most of the contributions received by the Member States dealt with the issue of the social transition to economic and monetary union, but that they showed contrasting views. The paper proposed to continue to analyse and monitor social protection policies in Member States, notably, through the Social Protection in Europe report.

Another proposal was to consider recommendations, the weakest form of EC legislation. The Commission proposed to hold joint discussions with Directors General responsible for employment and social security, and consultations with the 
social partners and other economic and social actors. In its communication to the Council in 1995, the Commission called on the Council to acknowledge the importance of developing a framework for debate on the future of social protection and to agree to associate all the players concerned at national and Community level, notably, the social partners ${ }^{35}$.

In conclusion, the Commission avoided proposing any substantive European legislation in the form of directives and any new spending commitments. Was this strategy a realistic acknowledgement of the high national resistance to European policy initiatives in this field? Perhaps, the answer is yes. We may also say that is a "wait and see" strategy, where emphasis is put on consultations and information.

\section{Social Security and EMU}

\subsection{Social and Political Implications of EMU for Social Security}

The links between EMU, macroeconomic policy and policies to redistribute income and to alleviate social problems are complex. Both earlier attempts at EMU, the Werner Plan of 1970 and the Roy Jenkins initiative of 1977, stressed the close link that exists between monetary and budgetary policy in any economy because of public deficit funding and problems of external imbalance. To avoid these difficulties and to enhance budgetary solidarity, they envisaged a form of fiscal federalism entailing a transfer system between EMU participants.

In 1977, a reflection group set up by the Commission investigated the budgetary requirements of EMU and submitted a report - the MacDougall report - on the role of public finances in European integration. The MacDougall report analysed the quantitative role of public finances with respect to inter-regional redistribution and inter-personal solidarity in five federal states (ex-Federal Republic of Germany, United States, Canada, Australia and Switzerland) and three centralised states (France, Italy and the United Kingdom). The report did not advocate a big federal budget of 20 or 25 percent of GDP, as it is the case in the United States or Germany, but recommended a much larger pre-federal budget of between 5 and 7 percent of Community GDP (or between 7,5 and 10 percent if defence was included). In essence, this increase was seen as a first step to increase inter-regional redistribution and to eventually reduce inequalities in per capita income within an economic and monetary union. It did not envisage big Community intervention in social security or health care, but strongly recommended the establishment of a Community transfer scheme for unemployment ${ }^{36}$.

The Heads of State and Government took a decisive step towards economic and monetary union (henceforth EMU) at the Hanover summit meeting in June 1988. They set up a committee of central bank governors and technical experts, chaired by the president of the Commission, Jacques Delors, to examine the ways and means of gradually bringing about EMU. The Delors report' outlined the conditions for the 
creation of EMU and proposed a three-stage plan. Wayne Sandholtz summarises three points concerning the conditions:

"Price stability would be the overriding mandate of the monetary union; support for general economic policies of the Community was subordinated to maintaining price stability. The European System of Central Banks (ESCB) would have a federal structure; that is, the common monetary policy would be determined at the centre, and national central banks, as branches of the System, would be responsible for day-to-day operations. The ESCB bodies would be "independent of instructions from national governments and Community authorities." ",37.

The overall design of EMU remained remarkably consistent with the Delors report. The most fundamental features of EMU - central bank independence, and the mandate for price stability- simply were not contested. In fact, central bankers and political leaders shared a consensus that price stability should be the primary goal of monetary policy and that independent central banks were better equipped to realise that goal. As John Woolley pointed out:

"This development will be unprecedented in the modern history of central banking. Never before has a powerful, autonomous central bank been established to govern a monetary union that was not itself the creation of pre-existing political institutions unambiguously in a position to express the national sovereign will"38.

The final treaty provided four criteria to be met by any state before it could take part in the monetary union:

Budget deficit can not exceed three per cent of GDP, and public debt can not exceed 60 per cent of GDP;

Inflation should not be more than 1,5 per cent above the average level of the three states with the lowest level of inflation;

Long-term interest rates must not exceed by more than 2 percentage points the average level of the three countries achieving the best price stability;

Currency must be within the normal fluctuation margins of the EMS for at least two years.

The treaty provided these tight convergence criteria, but allowed for flexible application by taking into account the trends in economic performance. For instance, a situation in which a country's public debt was over the threshold but steadily declining would be acceptable.

In 1996 a strong political will emerged at the EC level to start the third stage of EMU at the beginning of 1999, the second frame option in the Maastricht treaty. Attention centred increasingly on which Member States would qualify in the first wave to EMU and which measures are to be used. Eleven countries are now participating in the first wave to EMU, with the exception of the United Kingdom, Sweden, Denmark (which fulfilled the convergence criteria, but have decided not to participate) and Greece, 
(which wanted to participate but realised from the very beginning that it would not be able to do so).

The Delors report and the Maastricht treaty made strong links between monetary and budgetary policies. By contrast to earlier proposals calling for an increase in the Community budget, this time emphasis was put upon constraints on national budgetary behaviour. Despite the doubling of the structural funds and the introduction of the cohesion fund, the present EC budget represents little more than 1 per cent of Community GDP.

Both the Delors' report and the Maastricht treaty included provisions for monitoring the overall budget position of Member States and for punishing states that persist in running excessive deficits. The budgetary guidelines that serve as entry qualifications (the convergence criteria) remain in force after the start of monetary union. Monetary union implies a European Central Bank and a single Community currency. Economic union means multilateral surveillance of members' economic policies and punishment of countries that persist in running excessive deficits.

The main priority of convergence or harmonisation of economic and budgetary policies in EMU is merely to reduce inflation differentials, which otherwise may threaten monetary and exchange rate stability. Other objectives - e.g. to reduce unemployment, to improve working conditions, to maintain adequate social protection, to fight social exclusion, to improve health - appear somewhat attached or subordinated. Obviously, indicators with respect to these objectives can well be established and guide the management or the convergence of economic and budgetary plans at the European and at the national level.

Next we focus on recent debates, studies and reports dealing with the impact of EMU on social security. Before discussing the issues raised in these reports, we should emphasise a few points that relate to the advantages of EMU presented in the official documents and are generally well known. EMU was launched with the prospect of ensuring price stability and eventually lower interest rates. Its establishment would mean a saving on transaction and information costs. It would also mean less speculative flows of capital and would lead to more economic use of international reserves for Europe as whole. A single currency would become an important international currency and add power in relation to Japan and the USA. Lower inflation and interest rates would eventually become advantageous for government finances. EMU would strengthen economic development and thus the prospects for employment and prosperity would become brighter. As a result, tax revenues and revenues on social security contributions would possibly increase. In principle EMU would, therefore, be beneficial for social protection and its financing.

On the one hand, the EMU provisions do not contain requirements specifically aimed at cutting pensions, health care benefits and other elements of social protection. On the other hand EMU places emphasis on inflation rates and budgetary constraints. It raised considerable concerns about the additional pressures that it might create on social security revenue, especially under the current circumstances of high unemployment. Fears have been expressed that the convergence criteria might well lead to a situation in which labour market measures, social security, health care, 
education, research and development, public investment, would be viewed from the limited perspective of being a possible obstacle to EMU and a burden on the economy. EMU, thus, would offer legitimacy to restructure and indeed to reduce the welfare state.

\subsection{A review of the proposals and options}

EMU entails a fully centralised monetary policy whilst economic policies (labour market policy, budgetary policy, response to adverse or specific asymmetrical economic shocks) remain merely decentralised at the national level ${ }^{39}$. Discussion on how EMU affects social security hinged on this issue in the studies commissioned by the Commission, the European Parliament and the trade unions.

Two sets of arguments have been put forward. The first relates to stability policy in EMU, i.e. the chances of balancing production and employment at times of economic imbalance, such as macroeconomic disruptions perhaps leading to increased underemployment. These arguments were mainly raised by economists examining issues of macroeconomic policy and budgetary discipline under the EMU circumstances, in studies commissioned by the Commission.

The second set of arguments is more political and relates directly to the impact of EMU on national social security policies. In the context of efforts of Member States to comply with the convergence criteria and especially those related to public deficits and debts, a core question concerns what kind of political and social consequences the measures taken by governments may have for social protection and health care. Another fundamental question relates to what could be done at the $\mathrm{EC}$ level to ensure that economic and monetary integration does not create an additional burden on social security.

We focus now on the first set of arguments that relate to stability policy. In monetary union governments give up the manipulation of their currency. This applies to the internal value (inflation) and the external value (currency exchange rate). With respect to adverse economic shocks, for example, they can only respond either through variations in their wage and price levels or through migration. Since a deliberate migration policy is excluded, in monetary union states will be tempted to adjust to shocks by wage cuts and cuts in social security contributions.

They could also respond by running up their budget deficit and debt; but this option is no longer available, since their fiscal and budgetary sovereignty is subject to binding upper limits on deficits and debt (in per cent of GDP) under EMU. Following this line of reasoning, problems associated with differential levels of taxes and contributions social dumping and social competition - are likely to get worse.

Under the current circumstances, commentators and experts do not make a case for a bigger Community budget. Instead of punishment, they continue to make a strong plea for the co-ordination of budgetary policies in Europe in order to ensure that stabilisation policy is used effectively to fight widespread unemployment and, more generally, to safeguard the size of the public sector in Europe. They also stress the 
need for establishing a Community-wide insurance scheme between EMU participants for unemployment compensation ${ }^{40}$, educational grants and health programmes.

Van der Ploeg analysed the need and scope for macroeconomic policy co-ordination in economic and monetary union. He defined the co-ordination of economic policies as the joint and mutually consistent setting of national instruments of economic policies to maximise joint welfare of the Member States of the European Community. Conversely, lack of co-ordination means that each country sets its own instruments of economic policy without taking into account the consequences on welfare in other European countries ${ }^{41}$. He concludes that EMU poses a serious threat to the size of the public sector in Europe unless the budgetary policies of the various treasuries are coordinated:

"There are at least three fiscal externalities which pose a danger to the size of public sector in Europe, unless of course, budgetary policies of the various treasuries are co-ordinated. The first is that, as Europe becomes more and more integrated, spending by national treasuries on items such as the environment, training, research and development, foreign aid (e.g. Eastern Europe), and infrastructures, becomes more and more like a public good to all citizens of Europe, whose supply will be inadequate unless the treasuries co-ordinate their policies. The second is that international competition between the treasuries of Europe drives tax rates down and leaves less room for exhaustive public spending. The third is that treasuries may wish to loosen their fiscal stance in order to appreciate the real exchange rate of Europe and boost the real income of their citizens. Since such a policy also has beneficial impacts on the rest of the EMU-countries, public spending will be too low unless co-operation takes place" ${ }^{\text {"4? }}$.

In his view there does not seem to be a firm public-finance case for imposing upper limits on public sector deficits. It may be more sensible to impose limits on Member State treasuries borrowing from treasuries outside the European Community. Otherwise there may be insufficient control over the value of Europe's currency in international markets.

Further, he regrets the fact that the Delors report did not contain any recommendations for the establishment of a European Federal Transfer Scheme. He makes a strong case for a scheme that transfers income from regions with over-employment to regions with unemployment and which is budget neutral at the Community level, similar to the system envisaged by the MacDougall report of 1977:

"The political merits of an EFTS should be clear, because it ensures an equitable distribution of the gains and losses of EMU, it responds to basic citizenship rights of people living in the EMU, and it fits with the principle of horizontal equity. It also fits in with the principle of subsidiarity, because the job of arranging such transfers cannot be left to individual governments. .. In practice, the scheme operates by transferring income from individuals of one nation to individuals of another nation and replaces, to a certain extent, the national 
unemployment compensation scheme. One could envisage a Community-wide tax, which in itself would act as an automatic stabiliser, whose proceeds are used to finance a Community-wide unemployment compensation scheme. It is crucial that such a version of the EFTS is budget neutral. To be more precise the budget of the EFTS should be inter temporally balanced so that taxes are smoothed and that in time of a boom debt, which was accumulated in times of a recession, is paid off ${ }^{\prime 3}$.

Charles Wyplosz examined how the creation of monetary union affects the conduct of national fiscal policies. He concludes the same:

"The creation of a monetary union in Europe will seriously affect the conduct of national fiscal policies. The Delors report points out the need to restrict them, setting a binding ceiling on budget deficits, presumably on the ground that discipline is jeopardised. The present study finds where such risk exists. Yet, there are numerous instances where fiscal discipline may actually be enhanced. Under two separate definitions of what discipline may really mean, it appears that extreme caution should be exercised before setting binding rules. On the other hand, everything points towards the heightened need for co-ordination in the area of fiscal policy. Without the exchange-rate instrument, fiscal policies may well be called upon to provide a substitute way of dealing with national shocks. The guiding principle suggested is that of an insurance programme, linking individual agents throughout the union. Over time, this calls for the devolution of a number of national taxes and transfer programmes" ${ }^{\prime 4}$.

Furthermore he stresses that

"....it is individuals who are hit, not States or regions ...The insurance scheme should cover the risks - more precisely the portions of the risks - due to the existence of $M U$, not the risks which would have occurred to same extent in the absence of the MU...Priorities should be given to operations through the tax system, especially its progressive aspects.... The subsidiarity principle suggests to channel spending to existing national transfer systems...In all cases, spending should be directed in priority towards individuals affected by the adverse implications of the MU....Examples of programmes are: unemployment benefits, educational grants, health programmes.. ${ }^{\text {*tS }}$.

Alexander Italianer, working for the Commission, presents the results of a study examining the establishment of an automatic "stabiliser mechanism" of financial redistribution at the European level. The study simulated a system of transfers between the Member States, based on monthly harmonised unemployment rates since the start of 1980 s and until 1991. The transfer mechanism was applied on the basis of relative changes to unemployment, in relation to other countries, rather than on changes in the unemployment rate in a single country. Within its results 0,2 per cent of the Community's GDP would help to achieve, on average, the same degree of stabilisation 
as in the United States, where the federal budget has reached 30 per cent ${ }^{46}$. It is worth mentioning that instead of waiting for the establishment of a European transfer scheme, the Finnish Trade Unions (SAK) concluded an agreement on the creation of counter-cyclical EMU buffer funds on 17 November 1997. This stabilisation fund should take full effect from 2002-2004 onwards, making it possible to fund social security schemes (pensions and unemployment) ${ }^{47}$.

We turn now to the second set of arguments that relate mainly to the impact of the convergence criteria on social security ${ }^{48}$. As Begg put it, unemployment in the EC is already at a record level and annual average growth in GDP in the first half of the 1990 s barely reached 1 per cent. In most Member States in which unemployment is disturbingly high, Begg argues, that the combination of tight fiscal and monetary policies to meet the convergence targets will, in the short-to-medium term, push up unemployment and hence, the demand for social benefits, while incomes and revenues fall. Strong pressures will develop to diminish the quality and coverage of social protection. This could have damaging social consequences that would eventually threaten the political legitimacy of EMU. The adverse social consequences will be felt more in the Member States facing the biggest adjustments to meet the convergence criteria - Greece, Italy, Portugal and Spain. The outcome may well be a Europe of two speeds in income, social standards and monetary arrangements. Begg, argues that if EMU helps the economy of the EC to raise its sustainable rate of growth and the resulting growth is adequately spread across the Member States, there could be then little cause for concern about its social consequences. But if convergence entrenches high unemployment or obliges some Member States to make excessive cuts in their social budgets, the effects could be highly damaging to the economic and political case for $\mathrm{EMU}^{49}$.

Miller also pointed out that EMU makes the problem of finding resources for social security even more acute and thus increases the pressures for cost reduction and general reforms. He referred in particular to the countries with the worst budgetary position - Greece, Spain, Italy, and Belgium. In addition, he addressed the growing perception of people in these countries, but also in the others which presented convergence plans, that the convergence process is linked with the lowering of their social standards and indeed with the rise in unemployment.

$\mathrm{He}$ points out that EMU convergence requirements would lead to increased multilateral surveillance of members' economic policies. Eventually this would imply a greater say in the economic policy choices of a country and the attachment of conditions to its aid from the structural or cohesion funds and to loans from the European Investment Bank. In effect, multilateral control could force cuts in social security spending on the country concerned. Finally, he urged European trade unions to explore the possibilities of a pan-European collective bargaining system in the social dialogue under the Social Protocol or Agreement. This eventually could produce collective agreements moderating the pressure of EMU on wage and social costs ${ }^{50}$.

Nowhere better illustrates what kind of impact the transitional stage has had on social security than an overview of how the budgets of 1997 have been presented to the 
public, and how the social aspects of the EMU criteria have been dealt with. Pakaslanti looked at information and impressions transmitted mainly in the news media. He concludes,

"... the national budgets for 1997 have emerged as a cornerstone of EMU strategy. In many cases the budgets appear to the public as EMU-budgets designed to meet the EMU criteria. .. A general conclusion is that in many Member States the welfare system and the level of social protection will be affected by EMU.. .. EMU is a contradictory process tied to difficult decisions and associated with eventual negative impacts on certain sectors. The impact of the transitional stage differs among the Member States, and therefore has varying affects at the national level depending, for instance, on the structure of financing social security, and on how easy or complicated is to meet the convergence criteria at the national level "st.

Looking at the similarities of the role of social protection in the national EMU strategy for 1997, he delineates four groups of countries. Particularly in Germany, but also in France, Belgium and Austria the EMU criteria have been used as a means to transform social protection. In Germany the government presented major austerity proposals that included drastic changes in social and health benefits. The proposals faced forceful protests from the trade unions. In France, the budget was presented as clearly tailored to EMU and indeed the public deficit criterion of 3 per cent of GDP. Instead of drastic structural measures, the French method of achieving the 3 per cent deficit limit was by means of a one-off payment by France Telécom - for the government to cover future pension liabilities. This equalled to 0.5 per cent of GDP and was described as a result of the "magic of Maastrichtian mathematics". The government also presented plans to reform the financing of social security and the health care system, and to reduce public sector jobs. It could not proceed with drastic cuts mainly due to the strike wave of 1995, the trucker's strike that paralysed France in 1996 and the upcoming elections. It proceeded by increasing taxes and levies on alcohol and tobacco. In Belgium, expenditure on social protection has been subject to the severest cuts, in absolute terms. The cuts concern pensions, health care, child allowances and unemployment benefits. In health care, the government that included a temporary reduction in the tariffs of doctors and medical personnel and long-term increase in the tariffs concerning the stay in hospital took additional measures later. The central aim of the austerity measures presented in Austria was to reach the 3 per cent EMU convergence criterion by reducing the means for social security and education and by raising taxes.

The second group of countries includes Portugal, Spain, Italy and Greece. Entry to EMU in 1999 became a national priority in Portugal, Spain and Italy. It did so also in Greece, although the aim is to participate in 2001. Governments presented their austerity budgets clearly in connection to EMU in 1996. Nevertheless, they tried to follow a double strategy of leaving social protection mainly untouched, while trying to ensure entry to EMU by all other means. In Italy, the budget deficit reduction is to be achieved by cutting expenditure and increasing taxes. The social state had not to be touched on. Instead of cuts, emphasis has been put on tax-increases. One of these measures is well known as the "Euro-tax" which the trade unions managed to make 
progressive and thus put a greater burden on the middle class. The budget remains a nightmare in Italy and many fear that new sacrifices will require cuts in social security. In Spain, stringency and austerity in the budget centred around a freeze on public sector wages and employment, cuts in subsidies to industry and the launch of a privatisation drive to collect privatisation receipts. In Portugal, the aim of the budget was to meet the EMU targets without raising taxes or cutting social spending. The government presented a huge privatisation programme to raise revenues. The aim of the government in Greece was to reduce more than three percentage points in the public deficit mainly through increased tax revenues, cuts and tighter spending controls on state enterprises and welfare organisations.

Despite a different approach toward EMU, in the Netherlands, Denmark, Sweden and Finland, all countries close to the convergence criteria, governments did not present the 1997 budgets as the EMU budget. Despite some structural and financial changes in social protection, the Netherlands maintains a high level of social protection - the "Dutch model"- and qualified without major restraints to the third stage of EMU. Denmark and Sweden also qualified for entry to EMU, but have decided not to participate whilst Finland joined. The strategic goal of the government in each of these countries is to preserve the basic elements of the Nordic welfare model. Major concerns expressed in the Nordic countries centred on the political legitimacy of the powerful and independent European central bank responsible for monetary policy. As to the social consequences of EMU, the worries expressed relate mainly to the complete loss of freedom to conduct monetary and currency policy and eventually the consequences this might have for stability policy and, more generally, employment and social security issues.

The fourth group comprises Luxembourg, Ireland and the UK, which also are close to fulfilling the convergence criteria. Luxembourg and Ireland are going to join the EMU core group and this process does not impose constraints in social protection. Strong economic growth in Ireland has increased demands for income redistribution. The UK has, since the Maastricht treaty, adopted a wait-and-see strategy. The drastic changes in social protection and health care are not linked neither to the EC's social policy nor to EMU. The levelling down of the British welfare model has been the result of the long course of nearly the last two decades.

The outcome of this discussion can be summarised as follows. The introduction of a single currency may well be used as an instrument to promote the sustainable rate of economic growth and the creation of employment in Europe. This cannot be the outcome of the introduction of the single currency alone. Further, EMU represents a fundamentally new context for fiscal and budgetary policy, industrial relations, wage bargaining, social security rights, the level of social protection and the quality of health care services. Political realism suggests that monetary union can not become an end in itself. EMU creates pressures to reconsider the European social order. In order to avoid oversimplifications and demagogy, the best thing to do at the Community and the national level would be to assess the social and political implications of EMU and to discuss the more delicate issues at stake: the level of employment and unemployment; the co-ordination of budgetary policies; long term fiscal discipline; 
country-specific shocks; the structure of social security financing; and the level and quality of social protection and health care services.

Finally opinions and recommendations for Community action seem to have been converged around the following topics:

The introduction of investment programmes in line with the existing proposals of the Commission in the White Paper on "Growth, Competitiveness and Employment" (transport, energy, telecommunications, social and health services)

Discussing the structure of social security financing and in particular measures concerning the substitution of statutory charges on labour by, for example, environmental taxes, taxes on consumption and taxation on capital.

Breaking the apparent silence surrounding the effects of EMU on social security, to provoke a wider debate (involving, for example the Commission, the Council, the Parliament, the main political parties and the social partners) and to assess the impact of EMU on social security at the European and national level

Improving data collection, measurement, comparison, analysis and monitoring of social security systems at Community level

Guaranteeing the protection of social rights in the treaty, and discussing issues concerning sufficient levels of resources and benefits, and focusing on measures designed to strengthen convergence in social protection policies, particularly in the context of the Social Protocol and/or Agreement

The creation of a Council on Social Affairs, Employment and Social Security and to introduce concrete indicators into the Community and national economic and budgetary convergence plans with respect, for example, to employment, long term unemployment, unemployment of young people and women, poverty and health status of the population.

Discussing issues of stability policy and in particular the introduction of Community or national transfer schemes for unemployment, educational grants and health programmes.

\section{Summing up and Conclusions}

In spite of the harmonisation envisioned in the social provisions of the EC' $s$ establishing Treaty, Community regulation remained limited to protect the social security rights of those exercising their right to free movement. Thus EC law is set up to ensure appropriate social security cover for migrant workers, whether salaried employees or self employed, and their dependants.

The term harmonisation that occurs in the article 117 has been open to lengthy discussions and interpretations, studies and exchanges of information at the Community level. The central element of this debate has been the issue of social dumping. This issue was not considered a serious problem. The prevailing argument was that social security costs represent only one element of wage and labour costs. Divergence in social security costs across countries, therefore, does not necessarily 
determine competition. Hence, they do not justify Community harmonisation of national social security systems. Yet, some social provisions were introduced in the Single European Act, particularly in the field of occupational health and safety. The Act also created an institutional framework for social dialogue with the Euroorganisations of labour and industry.

In the light of the of the 1992 project, fears have been expressed that market integration will not only have substantial territorial and sectoral effects (these being only partly offset by the structural and regional funds). It will intensify corporate restructuring, particularly mergers and take-overs amongst the most successful enterprises, and closures and redundancies amongst the least successful. It will also intensify pressures to increase competitiveness and pressures towards the lowering of the social security standards. In short, economic integration will have substantial distributional consequences between social classes and groups of citizens.

Governments responded in both pragmatic and symbolic ways to the social consequences of economic integration. By "pragmatic" we mean the structural and cohesion funds. Greater scope to Community intervention was seen not so much in terms of regulating social rights, but in terms of promoting economic development in the less developed regions of the EC. The doubling of the structural funds, the introduction of the cohesion fund under the current financial perspective (which runs until 1999), the trans-European networks and the White Paper on growth, competitiveness and employment can all be viewed as the first hesitant steps towards this interventionist approach.

By "symbolic" we refer to fundamental social rights and in particular the Social Charter, which all governments adopted in 1989 in the form of declaration with the exception of the UK government. The governments declared that it was their responsibility to at least protect the social security rights of workers and citizens in the competitive markets of the 1990s. For example, in accordance with national practices, notably, through legislative measures or collective agreements.

Recent discussions about convergence in the regulation of social security systems, the raising of standards and proposals for the development of possible Community financing mechanisms, were formulated within this framework. To date, the initiatives in the field of social security to achieve the objectives set out in the Social Charter consist merely of non-binding measures (i.e. recommendations). In the recommendation on the convergence of social protection objectives and policies, the Member States clearly declared that there can be no question of harmonising the national arrangements concerning the organisation and financing of social protection. In effect, the 1992 recommendation on convergence set in motion a process of monitoring and improving data collection at Community level - the report on Social Protection in Europe, the monitoring group MISSOC, and ESSPROS, the Eurostat system for analysing and comparing national social protection expenditures and receipts.

Meanwhile, arguments were increasingly voiced for the inclusion of fundamental social rights in the legal system of the Community, i.e. in the treaty, going beyond the form of declared principles. Their inclusion would bring out the dualism inherent in 
any fundamental right or principle: that it is both a limit to power and a goal imposed on power. In short, the term convergence would gain in consistency and legitimacy if it was to be measured against the yardstick of these fundamental rights and objectives. Questions of possible financing mechanisms and of how to compare benefits in different countries were raised.

In the meantime, Member States started negotiations on the Maastricht treaty. Apart from new provisions on vocational training, the treaty left the main provisions concerning social policy and indeed social security largely unchanged. However, a Protocol on social policy was finally attached to the treaty, which authorised the Member States to continue along the path laid down in the 1989 Social Charter. The Social Charter was annexed to this Protocol as an Agreement on social policy between the Member States with the exception of the United Kingdom.

The Social Protocol or Agreement represents an institutional framework to discuss social security issues among the Council, the Commission and the social partners. The implications of the Social Protocol and Agreement for Community intervention in social security are open to interpretation. In the long term, it is difficult to predict what the outcome of these negotiations will be. Given the limited financial perspectives of the Community and the lack of authority to use fiscal policy, there is little the Community can promise labour for its co-operation in the short-to-medium term.

The concrete proposals, which the Commission presented after the Maastricht treaty, did not propose: any substantive European legislation in the form of directives; any new spending commitments in social security; nor an evaluation of the possible impact of EMU on social security systems. It mainly concerned exchange of information, discussions and consultations.

Meanwhile, the Heads of State and Government took decisive steps towards establishing EMU by 1 January 1999. It was launched as an instrument that would eventually become advantageous for sustainable economic growth, employment and prosperity in Europe. In contrast to earlier attempts at EMU, the Werner plan of 1970 and the Roy Jenkins initiative of 1977 , which envisaged a form of fiscal federalism between EMU participants, heavy emphasis was put on the constraints on national budgetary behaviour.

The design of EMU raised considerable concerns about the additional pressures that might be created on social security revenue, especially under the current circumstances of high unemployment. Fears were expressed that the convergence criteria might well lead to a situation in which labour market measures, social security, health care, education, research and development, and public investment, would be viewed from the limited perspective of being a possible obstacle to EMU and a burden on the economy. EMU could thus: speed up the process of cutting the size of the public sector and; eventually lead to a sub-optimal provision of public goods in Europe. Further, EMU would offer legitimacy to restructuring and indeed reducing the welfare state.

Monetary union represents a major policy regime change in the making of national fiscal and budgetary policies. Reports and studies made a strong plea to either coordinate budgetary policies or assess the possible social impact of EMU. They also 
considered the strong inequality between instruments provided for the creation of the internal market and EMU and those for economic and social policies.

The studies and reports, commissioned by the Commission and the European Parliament and the Euro-organisations of labour, focus mainly on the need to ensure that stabilisation policy is used effectively to fight widespread unemployment, and also more generally to safeguard the size of the public sector in Europe.

Commentators and observers suggested an enhancement of existing economic instruments to stimulate economic growth and employment. They proposed economic measures in line with, for example, the structural and cohesion funds, and the Commission's proposals for an investment programme in the White paper, "Growth, competitiveness, employment". In addition, they emphasised the need to introduce new social measures to soften the impact of EMU on social security. Above all, studies and reports intended to break the apparent silence surrounding the effects of EMU on social security, and provoke a wider debate involving the Commission, the Council, the Parliament, the main political parties, the social partners, researchers and the concerned public.

\section{Chapter Six References}

1 Giandomenico Majone, Which social policy for Europe, in Yves Meny, Pierre Muller and Jean-Louis Quermonne, The impact of the European Union on national institutions and policies, Routledge, 1996.

2 quoted by W. A. Glaser, Health Insurance in Practice, International Variations in Financing, Benefits, and Problems, Jossey-Bass Inc. Publishers, 1991.

3 H. Wallace, Distributional Politics: Dividing up the Community Cake, in H.Walace, W. Walace and C. Webb (eds), Policy-Making in the European Community, H. Walace, W. Walace and C. Webb, John Wiley \& Sons Ltd, 1983.

4 For a detailed overview of the activities of the Commission, see L.H.J. Crijns, The EC and Social Security: State of Affairs and Future Prospects, Working Document, European Institute of Public Administration, Maastricht, the Netherlands, 1991.

5 See Odile Quintin, The Convergence of Social Protection Objectives and Policies: A Contribution to Solidarity in Europe, and Yves Ghassard, The Convergence of Social Protection Objectives and Policies: A New Approach, in Commission of the EC, The Convergence of Social Protection objectives and policies, Social Europe, Supplement $5 / 92$.

6 Stanley Hoffmann, Obstinate or Obsolete? The Fate of the Nation-State and the Case of Western Europe, Daedalus, 95, 1966, p 862-915, p 863.

7 I.Nikolakopoulou Stefanou, The Social Policy of the European Community: Trends and Prospects, in Th. Christothoulidis and K. Stefanou, The Maastricht Treaty: A Comprehensive View, Athens: I. Sideris, 1995. 
8 Y.Ghassard, La construction Europeenne et la protection sociale, in Observatoire Social Europenne, Economic and Monetary Union and Social Protection, Working Paper 11, Brussels, 1995.

9 Eurostat, Enquete sur les Forces des Travail, Resultats 1996, Luxembourg: Office for Official Publications of the EC, 1997.

10 Commission of the EC, Growth, Competitiveness, Employment, The Challenges and Ways Forward into the 21 st Century, White Paper, Luxembourg: Office for Official Publications of the EC, p.9, 1993.

11 M. Huber, Health Care Financing in European Union Member States. An Initial Perspective based on recent OECD work on overall social trends, in R. Leidl (ed), Health Care and its Financing in the Single European Market, IOS Press, Amsterdam 1998.

12 M. Gold (ed), in his introduction to The Social Dimension: Employment Policy in the European Community, The Macmillan Press, 1993.

13 K. Busch, Economic and Monetary Union, Socio-Economic Dilemmas of European Monetary Integration, in Observatoire Social Europeen, Economic and Monetary Union and Social Protection, Working Paper 11, Brussels, 1995.

14 M. Gold, Overview of the Social Dimension, in M. Gold (ed.) The Social Dimension, Employment Policy in the European Community, Macmillan Press, 1993.

15 Commission of the European Communities, "Community Charter of the Fundamental Social Rights of Workers", Luxembourg: Office for Official Publications of the EC, 1990.

16 European Commission, Labour Market, Fundamental Rights and Social Policy in the Community, Report prepared by the Forward and Strategic Planning Group for DG V, May 1993.

17 See Commission of the European Communities, "Community Charter of the Fundamental Social Rights of Workers", Luxembourg: Office for Official Publications of the EC, 1990 , p. 5.

18 Commission of the EC, Second report on the application of the Community Charter of the Fundamental Social Rights of Workers, Social Europe, Supplement 1/93, Luxembourg, 1993.

19 Council Recommendation 92/441/EEC on common criteria concerning sufficient resources and social assistance in the social protection systems, OJ L 245, 26/8/92.

20 Council Recommendation on the convergence of social protection objectives and policies, OJ L 245, 26/8/92.

21 European Commission, MISSOC, Social Protection in the Member States of the European Union, Situation on 1July 1996 and evolution, Luxembourg 1997.

22 European Commission, Labour Market, Fundamental Rights and Social Policy in the Community, Report prepared by the Forward and Strategic Planning Group for DG V, May 1993. 
23 M. Dispersyn and P. van Der Vorst, La Construction d'un serpent social europeen, Etude de Faisabilite, Revue Belge de Securite Sociale, Annee XXXIV, Nos 4,5,6, Brussels: Ministere de la Prevoyance Sociale, Avril, Mai, Juin 1992, 315-656.

24 D. Pieters and S. Vansteenkiste, Social Security in the European Community: Coordination, Harmonisation or the Thirteenth State?, International Journal of Public Administration, 18(10), 1995, p 1639-1672.

25 See Garry Miller, The future of Social Security in Europe in the context of Economic and Monetary Union, Observatoire Social Europeen, Brussels, 1993. See also Iain Begg, The Social Dimension of EMU: What degree of solidarity is necessary or desirable?, in Observatoire Social Europeene, Economic and Monetary Union and Social Protection, Working Paper 11, Brussels, 1995.

26 M. Gold (edit.). "The EC Social Dimension: Employment Policy in the European Community". Macmillan Press, 1993.

27 Treaty on European Union, Luxcmbourg 1992.

28 Deirdre Curtin, The Constitutional Structure of the Union: A Europe of Bits and Pieces, Common Market Law Review 30, 1993, p 17-69. p 62.

29 Peter Lange, The Politics of the Social Dimension, in Alberta M. Sbragia (ed), Europolitics, Institutions and Policymaking in the "New" European Community, Washington, D.C. : The Brookings Institution, 1992, p. 250, p. 251.

30 Laura Cram, Policy-making in the EU, Routledge 1997.

31 Michael J. Gorges, Interest Intermediation in the EC after Maastricht, in Alan W. Cafruny and Glenda G. Rosenthal, The State of the European Community, Vol.2, The Maastricht Debates and Beyond, Lynne Rienner Publishers, Longman, 1993.

32 Commission des Communautes Europeenes, Livre Vert sur la Politique Social Europeenne, Options pour l' Union, Luxembourg, 1993.

33 Commission of the EC, Green Paper, European Social Policy, Options for the Union, Summary, Luxembourg, 1994, p17, p. 18, p. 19.

34 European Commission, A White Paper, European Social Policy, A Way Forward for the Union, Luxembourg, 1994.

35 Commission of the EC, The Future of Social Protection, A Framework for a European Debate, COM(95) 466 final, Luxembourg 1995.

36 Commission des Communautes Europeennes, Rapport du Group de Reflexion sur le role des finances publiques dans l'integration Europeenne, Volume 1: Rapport General, Bruxelles, 1977.

37 Wayne Sandholtz, Monetary Bargains: The Treaty on EMU, in Alan W. Cafruny and Glenda G. Rosenthal (eds), The State of the European Community, The Maastricht Debates and Beyond. Vol. 2, Lynne Rienner Publishers, Longman, 1993, p.127. 
38 John T. Woolley, Policy Credibility and European Monetary Institutions, in Alberta M Sbragia (ed), Europolitics, Institutions and Policymaking in the "New" European Community, Washington, D. C. : The Brookings Institution, 1992, p. 181.

39 Christophe Degryse, The Euro-Council: On the Way to "Economic Governance"?, in EMUinfo, no3, European Social Observatory, February 1998, p 2-6.

40 Niels Thygesen, member of the "Delors Committee" 1988-1989, EMU, The Stability Pact and fiscal requirements for sustainability, paper presented in the Colloquium "Social Challenges of Economic and Monetary Union", Brussels, 20 January 1998.

41 Frederick van der Ploeg, Macroeconomic policy co-ordination issues during the various phases of economic and monetary integration in Europe, in Commission of the European Communities, The Economics of EMU, Background studies for European Economy No 44 'One Market, one money', European Economy, Special Edition No 1, 1991, p. 136164, p. 140.

42 ibid, p. 159

43 ibid, p. 144

44 Charles Wyplosz, Monetary union and fiscal policy discipline, in Commission of the EC, The Economics of EMU, Background studies for European Economy No 44, 'One market, one money', European Economy, Special edition No 1, 1991,pp 165-184,pl 82 .

45 ibid, p.181

46 Alexander Italianer, Should a stabilisation fund be set up?, in Observatoire Social Europeen, Economic and Monetary Union and Social Protection, Working Paper 11, Brussels, May 1995.

47 Enrique Moro, Denmark, Sweden and Finland: Where the Social Players Stand, Observatoire Social Europeen, EMUinfo, No 3, February 1988, p 7-12.

48 For a good summary of the discussion concerning the convergence criteria and the financing of social security see the report of the Parlement Européen, Commission économique, monetaire et de la politique industrielle, Rapport sur les criteres de convergence pour l' Union économique et monétaire et le financement des systémes de sécurité sociale dans les étas membres de l'Union éuropéenne, Rapporteur: M. Frederik A. Willockx, Documents de séance, A4-0255/97.

49 Iain Begg, The social dimension of EMU: What degree of solidarity is necessary or desirable?, in European Social Observatory, Economic and Monetary Union and Social Protection, Working Paper 11, May 1995, pp 37-45.

See also, Iain Begg and David Mayes, The social consequences of economic and monetary union, European Parliament, Directorate General for Research, Working Papers, Social Affairs Series NE-1a (external study), Luxembourg, April 1994.

50 Garry Miller, The Future of Social Security in Europe in the Context of Economic and Monetary Union, A report for the EC commission (DG V), Observatoire Social Europeen, Brussels, 1993. 
51 Johannes Pakaslanti, Does EMU threaten European welfare? Social and Political Implications of its transitional stage in EU Member States, Observatoire Social Europeen, Working Paper Nr 17, June 1997, p 51, p 52. 


\section{7}

EC Public Health Activities \& Programmes:

Prevention, Health Information, Education \& Research 
(Based on Maria Theofilatou and Reiner Leidl, Public Health Policy and Health Services Research in the European Union, in Ulrich Laaser, Evelyne de Leeuw, Christiane Stock (eds), Scientific Foundations for a Public Health Policy in Europe, Juventa Verlag Weinheim und Munchen, 1995, and Giovanni N. Fracchia and Maria Theofilatou, The European Community's Research Projects in the Field of Health Services, International Journal of Technology Assessment in Health Care, 9:4, 1993, pp 554-563.)

\section{Introduction}

".. Of course, cancer and AIDS are not the only factors that must incite us to reflect upon our collective goals and our concept of the individual and society. Other transformations also contribute to this.

However, these scourges act as revealers, and often-dramatic ones. If we wish to give back to politics its lost dignity, which is the art of governing men and administering over things, we must examine our individual and collective responsibilities.

In what way do we wish to make use of science's discoveries? Where do we draw the line beyond which a person's integrity becomes threatened? How do we plan to redistribute wealth generated by economic growth, especially in terms of redistribution between private property and collective property such as health care policies, urban development control plans, the aid to developing countries?"

Jacques Delors (former President of the European Commission) ${ }^{1}$

"..The second imperative is to give the Community true powers in the field of health. Yesterday the Commission presented a concrete proposal to the IGC (Intergovernmental Conference) for a substantially revised Article 129.

The proposal involves three major improvements:

an improved procedure for co-ordinating the policies pursued by the Member States

the possibility, where necessary, for harmonisation at Community level in the field of human health;

co-decision on health matters

It is my belief that the time has come to put health to the fore in Europe."

Jacques Santer (President of the European Commission) ${ }^{2}$

This chapter concerns Community action on public health, and research related to the treatment of diseases. The Maastricht Treaty was the first treaty to establish an explicit legal basis for public health. Article 129 provided the EC with a formal 
competence to set objectives and priorities in the area of public health, to take decisions for the finance of these activities and to organise arrangements for their implementation. Although public health entered the institutional policy agenda of the EC only recently, the Community has initiated various ad-hoc programmes within the context of its social policy since the mid-1980s. Among the major initiatives launched were the programmes 'Europe against Cancer' (1987) and 'Europe against AIDS' (1991). These programmes resulted from many decision-making processes within the EC institutions including those from meetings of the Council of Ministers and the Ministers for Health within the Council. Co-ordination of medical and health research activities also started as a part of the EC's research policy in 1978.

The main question of this chapter is as follows: how did the EC move from ad hoc programmes to more active policy-making in the field of public health?

We begin with an overview of two well-known public health activities of the Community, namely 'Europe against cancer' and 'Europe against AIDS'. Then follows an analysis of part of the Communities research policy, namely medical and health research policy. Finally, we pay attention to article 129 in the Maastricht Treaty, its revision by the Amsterdam Treaty, and its implications for Community policy-making in the field of public health.

\section{Public Health Activities: Prevention, health information and education}

\subsection{Introduction}

Until the Treaty on European Union, which came into force in November 1993, the EC had no explicit mandate for public health activities. Yet, this lack of mandate did not prevent the EC from policy development relating to public health. Issues gradually crept into the Community's agenda. Prior to the Maastricht Treaty two typical public health programmes were started, 'Europe against cancer' and 'Europe against AIDS'. There were also some modest funds made available for public health (see table 1). All these activities set in motion a process that eventually led to the inclusion of Article 129 on public health in the Maastricht Treaty. All the time the Commission's Directorate General for Employment and Social Affairs (DG V), Public Health Unit was in charge.

Table 1 presents an overview of the EC budget for public health. This budget has always been very small, even after it was substantially raised in the second half of the nineties. This raise was an immediate effect of the Maastricht Treaty. 
Table 1. EC Public Health Budget (in millions ECU)

\begin{tabular}{|l|r|r|r|r|r|r|}
\hline & Cancer & AIDS & $\begin{array}{r}\text { Health } \\
\text { Promotion }\end{array}$ & Drugs & $\begin{array}{r}\text { Health } \\
\text { Monitoring }\end{array}$ & Total \\
\hline $1988-1989$ & 10 & & & & & 10 \\
\hline $1990-1995$ & 50 & 27 & & & & 77 \\
\hline $1996-2000$ & 64 & 49,9 & 35 & 27 & 13,8 & 189,7 \\
\hline
\end{tabular}

Source: Data is based on the Official Journal of the European Communities

Data for the period 1994-1995 comes from the Commission report on the implementation of the "Europe against AIDS" action plan 1994-1995, COM(96), 720 final.

\subsection{Europe against cancer}

\section{Early institutionalisation (1985-1987)}

The initiative to set up an action program to fight cancer was launched by the Heads of State and of Government of the European Community in 1985. On 28 and 29 June in Milan, the European Council expressed interest in a French memorandum of President Mitterand advocating a co-ordinated programme against cancer. The initiative was supported by the Italian Presidency and later in 1985, during the summit meeting of the European Council at Luxembourg it was confirmed ${ }^{2}$. In response to the conclusions of the European Council, the Council of Ministers for Foreign Affairs authorised the Commission to convene an ad-hoc committee of cancer experts. The experts met in Brussels and Paris in 1986, and recommended the development of Community action in four areas: cancer prevention, information of the public, training of health professions and cancer research ${ }^{3}$.

From the outset the Commission attempted to define a broad agenda for action in the field of public health to allow itself maximum flexibility. In 1986, it presented an action plan for the period $1987-1989^{4}$ which proposed 75 legal and financial activities under the four headings mentioned above. Under the heading of prevention, the action plan presented the legislative activities of existing Community programmes on workers' safety and the protection of the public against ionising radiation. The plan also extended the scope for Community action into new areas such as tobacco and nutrition. The legislative proposals on nutrition were later closely linked to Community policy in the field of consumer protection. Tobacco was introduced into this plan for the first time as a Community issue. As we shall discuss in section 3.2 below, the legal measures against smoking marked a breakthrough in public health policy by the EC.

Furthermore, the action plan put emphasis on a programme for systematic screening and early diagnosis of certain types of cancer such as breast cancer, cervical cancer, skin cancer, and colocteral cancer. It also proposed financial measures for health information, education and research activities and gave a boost to the cancer 
dimension within the existing Community medical and health research programme and other technology programmes covering biotechnology and information technologies.

In the summer of 1986, the Council and the representatives of the Governments of the Member States meeting within the Council, adopted a resolution which authorised the Commission to initiate a five-year action program, the 'Europe against cancer' programme ${ }^{5}$. In the absence of an explicit competence in the field of public health, the Council rejected to base its action programme upon any of the articles of the Treaty. Article 235 of EEC Treaty, which has often been invoked to justify action on environment, consumer protection or research-related matters, would have been an option. The article allows for action

"if action by the Community should prove necessary to attain, in the course of the common market, one of the objectives of the Community and this Treaty has not provided the necessary powers".

The Council did not use this article, however, (to avoid political difficulties) and opted instead to refer in its resolution to the general objectives of the Treaty establishing the European Economic Community. So, the justification for Community action was that the Community has,
"as its task to create a common market and, ....to promote throughout the Community an harmonious development of economic activities, a continuous and balanced expansion and an accelerated raising of the standard of living and closer relations between the States belonging to it".

Thus, the Council preferred to give an ad-hoc public health political mandate to the Commission and delineated the framework for Community action.

The Council asked the Commission to examine the relevance of existing Community programmes and legislation measures on cancer prevention. The resolution of the Council mentioned, in particular, Community activities in environment, consumer protection, worker protection, nutrition and agriculture. Furthermore, it gave priority to: measures against tobacco; protection measures for workers and the population from exposure to chemical substances; and the assessment of research results in nutritional habits and alcohol consumption. It also emphasised the exchange of information and experience on cancer preventive strategies and early diagnosis programmes. Another priority was the exchange of information on the existing structures and procedures for cancer epidemiology in Member States as well as the improvement of collection, availability and comparability of epidemiological data on cancer and factors causing cancer. The need for co-operation with other international organisations active in cancer prevention was stressed.

The Council and the Ministers of Health gave very specific mandates to the Commission to fight cancer, but failed to make available the necessary funds. As far as new financial activities were concerned, they asked the Commission and its Directorate General for Employment and Social Affairs (DG V) to submit proposals on a European cancer information campaign. They also referred to the Commission's intention to submit research proposals. However, research did not fall under either the 
scope of this mandate nor within the competence of Health Ministers. Research activities, especially clinical and fundamental research, had to be developed in the Commission's Directorate General for Science, Research and Technology (DG XII). The activities would have to be part of the Community's research policy and the framework programmes. This meant that Ministers for Research and Industry would be more involved in the final decisions than Health Ministers in the Council. The fourth medical and health research programme (1987-1991) contained for the first time a special section devoted to cancer research. A training scheme on cancer research became fully operational in 1988 .

In short, the first public health programme to fight cancer was set up as an initiative of the Heads of State and Government in 1985 that gave an ad hoc political mandate to the Commission to develop action against cancer. The Commission, supported by leading cancer experts, defined a broad agenda including four priority areas: cancer prevention, information of the public, training of health professions and cancer research. The next section presents a descriptive analysis of the "Europe against cancer" programme.

\section{The first action plan (1987 - 1989)}

On summer 1988, the Council adopted a decision to implement an information and public awareness campaign on the prevention, early screening and treatment of cancer. ${ }^{6}$ It allocated the modest amount of 10 million ECU for it. The campaign was addressed to the public, teachers and members of the health professions. Governmental as well as non-governmental organisations were identified as legitimate partners in the implementation process.

In its Communication of May 1990, the Commission reported on the implementation of the first "Europe against cancer" programme. ${ }^{7}$ In the area of prevention, the Commission reported on the first directives and other non-binding legal measures against tobacco. The first directive ${ }^{8}$ harmonised cigarette labelling. It included the appearance of health warnings and information on the tar and nicotine content on cigarette packets in the EC. As a result, the printing of the general warning "Tobacco seriously damages health" as well as strong medical warnings such as "Smoking causes cancer" or "Smoking causes heart disease" became compulsory. The second directive $^{9}$ limited the amount of tar on cigarettes sold in the Community to the fifteenmilligram norm recommended by the World Health Organisation by the end of 1992 and to twelve milligrams by the end of 1997. The action plan also succeeded in banning all tobacco advertising on television ${ }^{10}$ and presented a proposal for a Council directive on restricting or banning bills, posters and press advertising. In addition, a resolution" was adopted on banning smoking in public places and public transport.

The Community moves to develop a policy against tobacco met the opposition of many vested interests, such as tobacco industry and the agricultural sector, and caused considerable controversy within the EC institutions. On one hand the EC was subsidising tobacco under the Common Agricultural Policy, while on the other, it launched public health measures to combat smoking even though it lacked an explicit legal mandate to do so. The head of the 'Programme against cancer' unit commented: 
"Not only were the poor tobacco owners of Greece opposed to it, but even the wealthy producers of Perigord in France and of Bayern in Germany complained that this directive would ruin them". ${ }^{12}$

The Commission managed to solve the legal controversy by to presenting its proposals on health warnings and tar and nicotine content as part of the single market program instead of under the heading of public health ${ }^{13}$. Once again the liberation of interstate commerce was used to justify the adoption of the Commission's proposals and subsequently Article 100a was invoked as a legal basis. To pass the directives, the Commission also coalesced with national anti-smoking associations. It was even actively involved in the creation of the first pro-European health pressure groups.

As yet, it has still not been possible to agree on legal measures concerning both effective of banning advertising in the Community, and the upward alignment of taxation on tobacco manufactured in the EC. Still, the Community policy of subsidising tobacco production involves resources that far exceed EC spending on cancer $^{14}$

The limited budget of around ten million ECU for the first action plan supported activities that may be seen as the pre-decisional phase of this programme. The wording usually referred to pilot projects, case control studies, comparative analysis of national provisions, analysis of existing information, evaluation of existing policies, and establishment of committees and subcommittees.

In the field of information and health education, the main achievement was the "European Year of Information on Cancer" in 1989. It was designed to promote awareness of the preventive messages in the European Code against cancer among the general public and school children. The committee of cancer experts in 1987 originally drew up the ten recommendations that comprised the code. Their essential message was that certain cancers may be avoided and that more of them may be cured if detected earlier. European 'Weeks against cancer' which focus on specific areas of health promotion have been organised annually ever since.

With regard to the training of health professions, the Commission asked the existing advisory committees on the mutual recognition of diplomas and qualifications to advise on cancer training and to make recommendations for improving such training. The committees agreed on a series of recommendations concerning the oncology content of training programmes for doctors, dentists and nurses. Given their central role for cancer prevention and screening, the training for general practitioners was given priority.

\section{The second action plan (1990 - 1994)}

In May 1990 the Council adopted a second action plan "Europe against cancer" for the period $1990-1994^{15}$. The Council Decision provided 50 million ECU

"to continue and strengthen, from 1990 to 1994, the action undertaken between 1987 and 1989 in the fields of prevention, information and health education, and training of members of the health professions" 
It placed high priority on the,

"wider dissemination of knowledge of the causes, prevention, screening and treatment of cancer"

as well as on the production of European information modules, the European Code against cancer, the European campaigns of cancer information, European teaching material, European pilot networks of the health professions and so on. Emphasis was also put on

"promoting co-operation and co-ordination of national activities as well as the stimulation of Community activities".

The Council Decision presented both a work-plan and rules for its implementation. The Decision stated:

"The Commission shall be assisted by an advisory committee consisting of representatives of the Member States and chaired by the Commission representative. The duties of the Committee shall be:

to examine projects and measures involving co-financing from public funds

to co-ordinate at national level projects partly financed by nongovernmental organisations

Furthermore, the Commission will involve the high-level Committee of Cancer experts and the private bodies active in the fight against cancer closely in implementing the action plan. It will co-operate with both the World Health Organisation and the International Agency for Research on Cancer.

The Commission will continuously assess the action undertaken

The Council and the Ministers of Health will carry out a scientific evaluation of the effectiveness of the action undertaken."

By establishing pilot projects, issuing communications, supporting networks, organising colloquia, conferences, workshops, promoting TV programs and information campaign material, the Commission has drawn a range of national and European actors into the EC policy process on cancer. It managed to persuade and to prepare the ground for future competence in the public health field.

\section{The third action plan (1996-2000)}

The European Parliament and the Council, in accordance with the co-decision procedure, adopted the third plan of action in 1996. An amount of 64 million ECU's was allocated to the third "Europe against cancer" programme (1996-2000). This plan proposes action that builds on the experience of the preceding action plans. It introduces new areas of activity such as quality control in prevention and care, including palliative care. It supports the dissemination of the results of basic cancer research carried out under the Community's medical research programme. The annex 
of the decision ${ }^{16}$ summarises twenty-two specific action areas that fall under four main headings:

\section{Data collection and research}

. Information and health

Early Detection and screening

Training and quality control and guarantees.

With regard to data collection, the work-plan puts emphasis on the collection of reliable and comparable data on the incidence of cancer, including paediatric oncology. Activities support data collection and dissemination by the national cancer registers as well the development of a European network in co-operation with the International Agency for Research on Cancer (IARC). Support is also given to European-scale epidemiological studies relating to the identification of carcinogens (physical, chemical, biological), with special attention to environmental factors and factors related to working conditions.

In the field of health information and education, activities promote the preventive messages of the European code against cancer through information and awareness campaigns. Activities to assess national prevention measures and to contribute to the dissemination of best practice include pilot projects, studies and analyses. In the area of early detection and screening, activities support European pilot project networks in the field of mass screening for breast and cervical cancer, as well as feasibility studies on mass screening for other cancers. Training networks for health professions, consensus conferences on good practice and teaching materials are another field of support. For the first time priority is given to the analysis of quality control methods in care.

Emphasis is put once again on the co-ordination between three activities: the activities carried under this action plan against cancer; cancer research within the framework of research and development policy, in particular the biomedical and health research programme; and the advanced informatics in medicine programme (AIM). The third action plan provides support to the establishment of an inventory of European basic and clinical research to stimulate the transfer of results of basic research to clinical trials, to develop exchange of information on clinical trials in progress and to support the launching of multi-centre and multinational clinical testing.

As a matter of routine, the implementation rules ensure that the Commission implements the third action plan in close collaboration with a committee made up of two representatives from each member state. ${ }^{17}$ After consulting the committee, the Commission establishes priorities for an annual work programme. Projects have to fit the 22 actions set in the Decision's work plan and the priorities set in the annual work programme. They should involve participants from various Member States and be financed on the principle of shared costs (splitting costs between the programme and the applicant). 


\subsection{Europe against AIDS}

\section{Early institutionalisation (1983 - 1991)}

In September 1983 the Commission and its Directorate General for Research (DG XII) set up a work group of experts to explore the research needs posed by the emergence of the problem of Acquired Immunodeficiency Syndrome (AIDS), caused by a virus known as HIV (human immunodeficiency virus). Montagnier, then head of the Pasteur Institute, and Gallo of the American National Institute of Health, who were later to become two of the main actors in AIDS research, participated in the meeting ${ }^{18}$. The Commission co-sponsored four seminars in Copenhagen (immunology), Paris (virology), Bilthoven (epidemiology) and Brussels (clinical research) in collaboration with the WHO Regional Office for Europe and national institutions ${ }^{19}$.

In January 1984 the European Parliament called for the establishment of an emergency European research programme on AIDS and for measures to prevent the spread of AIDS disease through blood products and blood plasma. ${ }^{20}$ But there was a lack of political will among the Member States to agree with an involvement of the Commission in AIDS research, which was illustrated by the rejection of the Commission's request in June the same year for additional funds in AIDS research through the Scientific and Technical Research Committee (CREST) - a high-level advisory committee with representatives of national scientific and research interests ${ }^{21}$.

Yet, the Council and the representatives of Governments of the Member States within the Council formally acknowledged AIDS as a policy issue in a short Resolution in May $1986^{22}$. In the absence of an effective vaccine or cure for the viral infection, the Council recognised the importance of the co-ordination of research efforts and activities in the field of health information and education. It also emphasised the importance of establishing Community legal measures to solve the problems of AIDS transmission.

In 1987, the Council authorised the convening of an ad-hoc Working Party of public health officials on AIDS with the participation of the Commission,

"... in order to draw up as soon as possible a common strategy leading to a plan of action and of co-ordination to be carried out by the Member States and at Community level ${ }^{\prime 23}$.

The same year the Commission issued a communication, which identified a number of areas of action in relation to prevention and control of HIV/AIDS transmission ${ }^{24}$.

It would take four years, before the Council and the Ministers for Health decided finally to launch public health action, namely, the first "Europe against AIDS" program for the period 1991 - 1993. In the meantime, the Commission took up the mandate of the Council and engaged through its Directorate General for Research (DG XII) in AIDS research activities under the 1987 - 1991 Fourth Medical and Health Research Programme (MHR4). The Medical and Health Research programme initiated a wide range of research activities concerning AIDS, including monitoring and 
prevention, viro-immunological research, clinical research, drug trials, as well as the development of the European Vaccine against AIDS (EVA). In 1987 the EC also launched an AIDS programme under the Lome convention to support Afro-Caribbean and Pacific countries (ACP). The next year the programme was extended to cover all developing countries. This part of action on public health was carried out by the Directorate General for Development (DG VIII). Research was administered by the Directorate General for Research (DG XII) and in particular the sub- programme Tropical Medicine ${ }^{25}$.

In brief, the Commission in 1983 and the Parliament in 1984 began a debate on making a commitment to AIDS research. AIDS and AIDS- related problems have been on the Council's agenda continuously ever since. The Community's strategy for AIDS developed in three fields, namely public health measures and co-ordination of prevention strategies, research and development programmes, and activities for developing countries. The discussion below is limited to a descriptive analysis of measures in public health, prevention and information. It includes the "Europe against AIDS" programme, managed by the Directorate General for employment and social affairs (DGV).

\section{First action plan (1991-1993, 1994-1995)}

During the period 1986 to 1991 the Council and the Ministers for Health adopted a number of non-binding texts in relation to AIDS, including resolutions and conclusions. In 1989, these texts drew attention to various aspects of the AIDS problem. They culminated in the adoption of a Council Decision on a first "Europe against AIDS" programme in June 1991.

In combating AIDS, the Council and the Ministers for Health stressed the ineffectiveness of systematic and compulsory screening and placed high priority on prevention strategies through health information and education. Furthermore, they pointed to the need for protecting individual rights and to measures against discrimination, particularly regarding employment ${ }^{26}$. In addition, they addressed the prevention of AIDS in intravenous (injecting) drug users ${ }^{27}$ and the need of awareness measures for health care personnel ${ }^{28}$. The Council and Ministers for Health also called for improvements in the collection of epidemiological data and asked the Commission, in co-operation with the WHO-collaborating centre in Paris, to guarantee the quality and comparability of all epidemiological data available in the Member States ${ }^{29}$. The Commission provided support to the European Centre for the Epidemiological Control of AIDS. This had been established as a WHO-centralised facility for the epidemiological monitoring of AIDS since the epidemic in St. Maurice near Paris in 1984. This centre is now a WHO-EC Collaborating Centre and collects, analyses and redistributes data from 31 European countries. In contrast to many other diseases, there are internationally agreed definitions on how to report on AIDS. Consequently, the incidence of AIDS and its mortality rates can be calculated.

Furthermore, the Council called for the establishment of Community legal measures and asked the Commission, 
"to examine, within the framework of the internal market, the possibilities for harmonisation of the technical requirements and availability of HIV self testing kits, and the possibilities for improving at Community level the HIV-related technical safety requirements for organs, tissues, semen and blood",30.

The Community's research policy on vaccines, treatment and epidemiology had also to be expanded. There was an urgent need for continuing and strengthening research activities.

In 1990, via a Resolution, the Council gave the Commission a new mandate in the exchange of information and experience ${ }^{31}$. The Resolution set six priority topics that guided the action within the "Europe against AIDS" programme. The priority topics covered the following activities in the field of prevention:

assessment of national prevention measures, including assessment of information campaigns and problems that may concern women or certain categories of persons,

preventive measures aimed at drug addicts,

technical ways of improving safety in the use of substances of human origin, care of infected persons,

health information and education for young people,

implementation of the conclusions of the Council and the Ministers for Health concerning AIDS and the place of work.

In June 1991 the Council and the Ministers for Health adopted an action plan "Europe against AIDS" for 1991 - 1993, and allocated an amount of six million ECU to finance activities in the field of prevention, health information and education for 1991-1992 ${ }^{32}$. As in the case of the "Europe against cancer" programme, reference was made to the treaty establishing the EC. Action against AIDS was not based upon any of the articles of the treaty. "Without prejudice to the responsibilities of the Member States in this area", an ad-hoc political mandate was given to the Commission to develop both exchanges of information and experience, and appropriate measures to prevent and control AIDS. The decision outlined ten action areas:

Assessment of the knowledge, attitudes and behaviour of the general public and target groups

Informing and increasing the awareness of the public and certain target groups

Health education for young people

Prevention of HIV transmission

Social support, counselling and medical treatment

Estimating the cost of managing HIV infection

Gathering data on HIV/AIDS

Enhancement of human resources 
Measures to combat discrimination against HIV - infected persons and persons close to them

Research and international co-operation.

The decision also stated rules for implementation. Implementation entailed close cooperation between the Commission and an advisory committee composed of representatives of the Member States. In implementing the action plan, the Commission would co-ordinate projects and measures involving co-financing from public funds as well as projects partly financed by non-governmental organisations. The non-governmental AIDS service organisations (ASOs) were thus recognised as legitimate partners. The European ASOs form part of an international ASOs network founded in 1990. The network also include gay and lesbian organisations, organisations for people with AIDS and organisations for drug users ${ }^{33}$. In implementing the action plan, the Commission was also asked to ensure complementarity with the research activities carried under its biomedical and health research programme and to seek collaboration with international organisations, in particular WHO and the Council of Europe.

From 1991 to 1993 the Commission supported the establishment of formal and informal networks and drew a range of actors, including national AIDS co-ordinators, other external organisations and social networks into the EC policy process. The Commission used advisory committees and expert groups and supported workshops, seminars, conferences, surveys, and prevention campaigns ${ }^{34}$. The budget for 19911993 was mainly allocated to actions concerning prevention, social support and counselling ${ }^{35}$.

The 1991-1993 "Europe against AIDS" programme was extended ${ }^{36}$ until the end of 1995. During this period 17,7 millions ECU were made available to support 134 projects. The average Community contribution per project was between 50 and 70 per cent ${ }^{37}$. Three areas of activity received priority and accounted for over 70 percent of the funds allocated. These areas included (a) the assessment of the knowledge, attitudes and behaviour of the general public and target-groups, (b) the prevention of HIV transmission among particular groups and in particular settings, and (c) gathering data on HIV/AIDS.

The Commission could thus report ${ }^{38}$ that those most involved in AIDS prevention participated in the activities of the programme. In addition, transnational networks were formed around target groups and specific settings including drug users, prisoners, prostitutes, travellers, migrant workers and ethnic minorities. The collection and analysis of data were also supported through the European Centre for the Epidemiological Monitoring of AIDS. In addition, Community legal measures ensuring the safety of blood products in the single market were established. For example, the Council Directive 89/381/EEC covered the safety issues for the industrially manufactured blood products. 


\section{The second action plan (1996 - 2000)}

In 1996, the European Parliament and the Council adopted the second plan of action for $1996-2000^{39}$. The amount of 49,6 million ECU was allocated to the prevention of AIDS and certain other communicable diseases, in particular tuberculosis, hepatitis, sexually transmissible diseases and other diseases treatable by vaccination. The new programme focuses on nineteen actions falling under four headings, these include:

\section{surveillance and monitoring of communicable diseases}

combating transmission

information, education and training

support for persons with HIV/AIDS and combating discrimination.

Let us, before we proceed with a discussion of the medical and health research section of the Community's research policy, briefly draw some general conclusions on both disease-related policy programmes of the EC. Our first conclusion is that the EC was involved in public health activities long before it was given a formal mandate to undertake such activities in the Maastricht Treaty on the European Union. One may argue therefore, that article 129 of the Maastricht Treaty was, at least to some extent, a codification of an already existing practice.

The second conclusion is that both programme titles suggested more than they actually brought. Neither 'Europe on Cancer' nor 'Europe on AIDS' were large-scale programmes supported by huge community resources. In fact, both programmes were small programmes for which only a modest amount of financial resources were made available.

The two programmes also point to political difficulties connected with the initiation of public health activities by the Community. Policy decisions of the Council and the Ministers for Health are only a first necessary step in the process of policy development. When it comes to a further concretisation of these decisions, there may be difficulties between the Member States in reaching agreement due to national interests and a certain reluctance to give the Commission a strong position in public health affairs. The Commission on its part had to manoeuvre very strategically in order to respect the subsidiarity principle and to make real progress. The strong emphasis upon co-ordination of national activities can only be understood against this political background.

Finally, our analysis hints to the fragmented structure within the Community's policymaking machinery. Whereas 'Europe against Cancer' and 'Europe against AIDS' were co-ordinated by DG V (Public Health Unit), research activities in both fields resided under DG XII. 


\section{Medical and Health Research as a part of Community's Research Policy}

\subsection{An introduction to the EC research and development (R\&D) policy : The Framework Programmes}

The study of Community medical and health research activities requires a brief history of the Community's research policy. The Community had started to fund R\&D activities under the ECSC Treaty (1951) and the Euratom Treaty (1957). Apart from agricultural policy field (art.41), the Treaty establishing the EEC, the Treaty of Rome (1957), did not include science and technology in its policy agenda. Co-operation mainly concentrated upon nuclear research. The first big nuclear research establishment, was the result of intergovernmental co-operation and was set up outside the Community institutional framework. The foundation of the European Organisation for Nuclear Research (CERN) in 1953 mirrored the preoccupation of scientists and governments with the creation of an European laboratory capable of promoting an ambitious plan of fundamental research in high energy particle physics.

Some 15 years later, the Commission undertook a series of initiatives to promote scientific and technological co-operation ${ }^{40},{ }^{41}$. Spinelli (1970), a convinced federalist and Commissioner for Industry, Research and Technology, constantly attempted to increase Community powers in research policy. He proposed to set up the European Research and Development Committee (CERD) and the European Research and Development Agency (ERDA), an ambitious project equivalent of the American NASA. Both initiatives failed to reach Council's approval. His successor Dahrendorf (1973), was convinced that research and development policy would remain a national policy issue at least in the short-to-medium term. Thus, he concentrated his attempts more on the co-ordination of national policies than on increasing the Community powers in research and development. In his view research and development should aim at two great objectives: improving the quality of life and regenerating the European industry. His work programme sought to define standards to determine what tasks rightly belonged at a European level. As far as science and education were concerned, his aim was to set up a "European Scientific Area", which would result in greater cooperation between the Member States. For this purpose it would be necessary to increase the mobility of researchers within the Community, and also to encourage joint actions and co-operation projects. Under this perspective, the work programme suggested the drawing up of a register of laboratories suitable for carrying out research at a European level, and the creation of a network of professionals working in these laboratories. The aims were to guarantee the co-ordination of effort in the case of expensive long-term projects, and to make particularly expensive installations function to common advantage ${ }^{42}$.

In 1974 the Member States finally agreed upon the proposals of the Commission and interpreted article 235 of the EEC Treaty in a manner that opened the way for the adoption of wide variety of Community research initiatives outside the nuclear field. The Council of Ministers adopted four resolutions and created a high level advisory 
Scientific and Technical Research Committee (CREST), made up of national representatives. The resolutions were the first of their kind and various research programmes would be based upon them, including the first Medical and Health Research programme in 1978. In the meantime, intergovernmental co-operation outside the EC institutional framework continued, resulting in the establishment of ESA (European Space Agency) in 1975 and the European Molecular Biology Laboratory (LEMB) in 1974. In addition, the European Science Foundation was established in 1974, associating 54 member research councils, academies, and other institutions in 20 countries $^{43}$.

European technological co-operation became an urgent issue at the beginning of the 1980 s. Economic preoccupation and in particular the loss of industrial competitiveness compared with Japan and the USA, dominated various EC and intergovernmental initiatives in the field of innovation. Industrial competitiveness became the most important priority in reinforcing EC action in the field of information, telecommunications, new materials and biotechnology. The EC support to industrial research did not cover activities leading directly to the development of new products. Rather, Community action was situated in a "precompetitive" or in some cases "prenormative" context, somewhere in between basic and industrial research. Moreover, the EC sought to integrate its disparate research programmes in 1984. This led to the first framework programme for Community R\&D activities (1984 - 1987). That was a strategic five-year plan that set general objectives and priorities as well as a budget for all specific research programmes.

Furthermore, an intergovernmental initiative under the name of Eureka (European Research Co-ordination Agency) was launched in 1985 after a proposal of the French president Francois Mitterand. Eureka aimed to support civilian applications of advanced technologies, directed both at private and public sector markets. Areas of action included information technologies, telecommunications, transport, biotechnology, robotics, laser, and environment ${ }^{44}$. The British and German governments did not adhere to the French idea concerning the establishment of a European research agency. Italy and the Benelux countries expressed their will to locate European technological co-operation in the institutional EC framework of action that would offer better guarantees to participants ${ }^{45}$.

The decisive breakthrough of a comprehensive Community strategy on research was made by the Single European Act in 1987. The Single Act brought science and technology within the formal competence of the EC (art. $130 \mathrm{f}$ to q). According to the provisions, industrial competitiveness remained central in the two Framework Programmes, adopted in 1987 and 1990. These programs did not put an explicit link between EC research policy and policies in the field of the environment, education or health. Yet, it was acknowledged that industrial competitiveness was not the only objective of EC research policy. Science and technology could also contribute to a better environment and better health care. The first report on the state of science and technology in Europe presented by the Commission (1988) made the pursuit of these goals a priority: 
"Science and technology are vital in improving Europe's competitive position in the context of the completion of the internal market. They also have a major contribution to offer in meeting the societal needs of the European society for a cleaner and safer environment and better health care". ${ }^{46}$

Activities relevant to health witnessed a steady expansion during the $1980 \mathrm{~s}$. The health issues covered by the research programmes ranged from prevention, to pure medicine and related fields such as biotechnology and the application of advanced informatics to medicine. Geographically, health problems addressed in these programmes ranged from the West to the East and to developing countries [e.g. the STD programme, (Science and Technology for Developing Countries) and the PECO programme, (Pays de l'Europe Centrale et Occidentale)].

The Treaty on European Union broadened the scope of Community research activities to support the application of various Community policies (art. 130f), including health. The inclusion of public health into the formal EC competencies further increased legitimacy and credibility to ongoing and new research activities in the field of medical and health research. ${ }^{47}$

Table 2 highlights major changes in EC priorities and funding between framework programmes for the period 1982-1998. The table highlights the enormous increase in the efforts to stimulate RTD action in the Community, from 3750 MECU in the first Framework programme to $12300 \mathrm{MECU}$ in the fourth programme - a growth of more than 325 percent.

In 1982, the EC budget was $500 \mathrm{MECU}$ of which 66 per cent was spent on energy, reflecting largely nuclear research activities based on the Euratom Treaty. Life sciences and technologies, including basic biotechnology research, biomedical and health research, and agricultural research, altogether represented only 3 per cent of the budget.

Table 2: Changes in RTD funding priorities between EC Framework programmes. (Unless otherwise indicated, figures represent percentages of total budget.)

\begin{tabular}{|l|r|r|r|r|r|}
\hline Homogeneous groups & 1982 & $\begin{array}{r}\text { 1st FP } \\
1984-1987\end{array}$ & $\begin{array}{r}\text { 2nd FP } \\
\text { 1987-1991 }\end{array}$ & $\begin{array}{r}\text { 3rd FP } \\
1990-1994\end{array}$ & $\begin{array}{r}\text { 4th FP } \\
1994-1998\end{array}$ \\
\hline $\begin{array}{l}\text { Information and } \\
\text { Communication technologies }\end{array}$ & 10 & 25 & 42 & 38 & 28 \\
\hline $\begin{array}{l}\text { Industrial and Material } \\
\text { technologies }\end{array}$ & 9 & 11 & 16 & 15 & 16 \\
\hline Environment & 9 & 7 & 6 & 9 & 9 \\
\hline $\begin{array}{l}\text { Life sciences and } \\
\text { Technologies }\end{array}$ & 3 & 5 & 7 & 10 & 13 \\
\hline Energy & 66 & 50 & 22 & 16 & 18 \\
\hline
\end{tabular}




\begin{tabular}{|l|r|r|r|r|r|}
\hline Homogeneous groups & & $\begin{array}{r}\text { 1st FP } \\
\text { 2nd FP }\end{array}$ & $\begin{array}{r}\text { 3rd FP } \\
\text { 1980-1994 }\end{array}$ & $\begin{array}{r}\text { 4th FP } \\
\text { 1994-1998 }\end{array}$ \\
\hline Transport & 0 & 0 & 0 & 0 & 0 \\
\hline Socio-economic Research & 0 & 0 & 0 & 0 & 1 \\
\hline International Co-operation & 0 & 0 & 2 & 2 & 3 \\
\hline Dissemination and & 0 & 0 & 1 & 1 & 3 \\
\hline Exploitation of results & & & & & $1987-1991$ \\
\hline Human Capital and Mobility & 3 & 2 & 4 & 9 & 6 \\
\hline Total \% & 100 & 100 & 100 & 100 & 100 \\
\hline Total amount (MECU) & 500 & 3750 & 5396 & 6600 & 12300 \\
\hline
\end{tabular}

Source: EC, "The European Report on Science and Technology Indicators 1994", EUR. 15897.

In 1984 the first framework programme (1984-1987) was launched with a research budget of $3750 \mathrm{MECU}$. Energy remained the major priority, taking half of the budget allocated to research. ICT and industrial RTD grew from 19 to 36 percent. The increased interest in these topics was also demonstrated by the establishment of the Industrial Research and Development Committee (IRDAC), consisting of members chosen by the Commission and European industrial organisations on a national basis. The relative position of life sciences slightly increased to 5 percent.

The second Framework programme (1987-1991) was adopted under the Single Act. This programme was even more oriented at industrial competitiveness and advanced technology. ICT and industrial RTD accounted for 58 per cent of the total budget. The ICT part included a specific programme directed at the health care sector (AIM). Specific objectives of this programme were the application of information and communication technologies (telematics) in health care as well as the improvement of quality and cost-effectiveness in medicine. The share of life sciences again slightly increased to 7 percent.

Industrial RTD and ICT remained a first priority in the third Framework programme (1990 - 1994), although their total share dropped by 5 percent. ${ }^{48}$ The modest but steady growth of life sciences continued. The budget allocated to biomedical and health research (BIOMED I) was 133 million ECU's for the period 1990 - 1994.

The fourth Framework (1994-1998), which now includes all the Community's research and development activities, was adopted under the policy-making rules of the Maastricht Treaty in May $1994^{49}$. Priorities became more diversified than ever. The share of life sciences further grew to 13 percent. Substantial increases in funds included both biotechnology, and biomedical and health research (BIOMED II).

Regarding the decision-making procedures, the adoption of the framework programme follows the rules of the co-decision procedure between Council and Parliament, while the adoption of the specific programmes is made through the co-operation procedure, requiring qualified majority voting by the Council and merely consultation by the 
Parliament. Wide consultations between the Commission and national, industrial and scientific interests precede the establishment of the framework program and the specific programmes as well.

If we briefly look back, our main conclusion must be that over the last twenty years the Community has significantly increased its efforts to stimulate research in a broad sense. The growth of the total budget for research clearly demonstrates this development. Nowadays, "Scientific Europe" comprises research activities carried out by universities, public and industrial laboratories, international non-governmental research centres, and so on. Contracting with the Community on research has gradually become a prestigious activity.

The growth in financial efforts was only one significant development, however. Another milestone was the adoption of the Single European Act in 1987, which brought science and technology under the formal competence of the Community. It took much political manoeuvring to achieve this result. Initially, Member States did not see a clear role for the Community. They preferred to collaborate with each other by means of intergovernmental initiatives. But the growing need for boosting the industrial and technological capacity of the Community to keep up with developments in the USA and Japan gradually paved the way for a formal Community role in research and development. The Treaty on the European Union further broadened the scope of Community research activities to support Community policies, including public health.

It is interesting to note that the lack of a formal competence in science and technology did not prevent the Community from initiating activities in this area. When the SEA was adopted there was already a budget for RTD. Furthermore, the first Framework programme was launched before the Community got a legal competence in research and science. Thus, we see here a similar pattern as in the field of public health where also various activities were undertaken without a specific competence of the Community.

An analysis of the spending under the fourth framework programme reveals interesting developments. Whereas the share for energy substantially decreased, the share for ICT and industrial RTD significantly increased. This changed spending pattern reflected the perception that the Community had to stimulate ICT and industrial RTD in order to protect and improve its competitive power in an even more competitive world. Furthermore, we can observe that the spending pattern, although remaining limited, became somewhat more diversified i.e. whereas Energy, ICT and industrial RTD accounted for 86 percent of the budget in the first Framework programme, their share in the fourth programme was still 62 percent.

Finally, we point to the fact that the share of life sciences and technology, of which the BIOMED-programmes formed a part has steadily grown from 5 percent in the first Framework programme to 13 percent in the fourth programme. 


\subsection{Medical and Health Research}

Community attempts to initiate a medical and health research programme date back to the establishment of the high level advisory Scientific and Technical Research Committee (CREST) in 1974. One of the then five specialised committees of CREST was the Committee of Medical and Public Health Research (CRM - Comité de Recherche Medicale). The CRM members, all national representatives, found it difficult to agree on what form Community intervention should take in medical and health research. To use the words of Baert, former head of the programme,

"national resources and strategies, public and private (including the pharmaceutical industry), seemed adequate in this area. On the other hand, it was impossible to ignore the number of Nobel Prizes going to American researchers in biomedicine. Why was Europe not matching this performance? The answer appeared to lie in the "critical mass" that an organisation such as the National Institute of Health in the United States could mobilise ${ }^{\prime 50}$.

However, Europe was not a nation and CRM members launched a series of preparatory activities, pilot studies, workshops and seminars before finally agreeing on some kind of Community co-ordination of national medical and health research activities. The Council adopted the first Medical and Health Research Programme (MHR1) in 1978. The initial pilot research programme was extended by a second programme (1980-1983 MHR2) and a third programme (1982-1986 MHR3). Specific co-ordination of projects in health services research started in the third programme. The fourth programme (1987-1991) contained specific cancer and AIDS research projects.

Remarkably, before 1988 there were no public calls for proposals and scientists had to rely on national representatives to keep them informed of funding opportunities. The selection process relied exclusively on the Management and Co-ordination Committee (CGC), advised by its Working parties (WPs) and Concerted Action Committees (COMACs), all composed of national representatives and scientific experts, nominated by the Member States. Since MHR4, public calls for proposals have been issued and project selection has become subject to peer review of independent scientific experts.

In contrast to all other Community research programmes, the medical and health research programme with one exception adopted the "Concerted Action" (CA) method of support. Research itself was not funded, only the costs of bringing the teams together. With the exception of the latest MHR, Community funds only covered the running of Trans-European research networks (about 5 per cent of the total research costs). Under this form of funding, the Community supported the scientific management of the network; the organisation of meetings and workshops; short-term staff exchanges and visits; centralised data handling, storage and statistical analysis; publications and more generally dissemination of information and results. In addition, a "centralised facility" could be provided to ensure appropriate European resources or services. Research itself remained financed by Member States and national bodies. The only exception to this general practice was the human genome project in the BIOMED 
1 programme for which support was provided through 'shared cost-actions' with the EC normally meeting up to 50 per cent of the cost of research.

The contribution of the Community budget for co-ordination purposes was one million ECU in 1978 and has increased to 336 million ECU in the BIOMED 2 programme, a growth of $150 \%$ (see table 3 ). Yet, the BIOMED 2 programme represents only $2.3 \%$ of the Community Framework budget for research (1994-1998).

Table 3: Funding of Biomedical and Health Research at EC level 1978-1998

\begin{tabular}{l|l}
\hline Research Programme & Funding (MECU) \\
\hline 1978-81 MHR1 & 1.09 \\
1980-83 MHR2 & 2.32 \\
1982-86 MHR3 & 13.3 \\
1987-91 MHR4 & 65 \\
1990-94 BIOMED 1 & 133 \\
1994-1998 BIOMED 2 & 336 \\
\hline
\end{tabular}

Source: European Union, Biomedical and Health Research, IOS Press, 1995, p.33.

The objectives of BIOMED 2 are to improve the health of European citizens and populations, to strengthen the scientific basis of the competitiveness of the European health industry, and to promote the transfer of research results into clinical practice. The funds are allocated to seven research priority areas: pharmaceuticals, biomedical technology and engineering, brain research, diseases with major socio-economic impact (cancer, AIDS, cardiovascular diseases etc.), human genome research, public health research, including health services research and research on biomedical ethics (see table 4). 
Table 4: BIOMED 2 (1994-1998): distribution of funds and main mode of implementation per research area

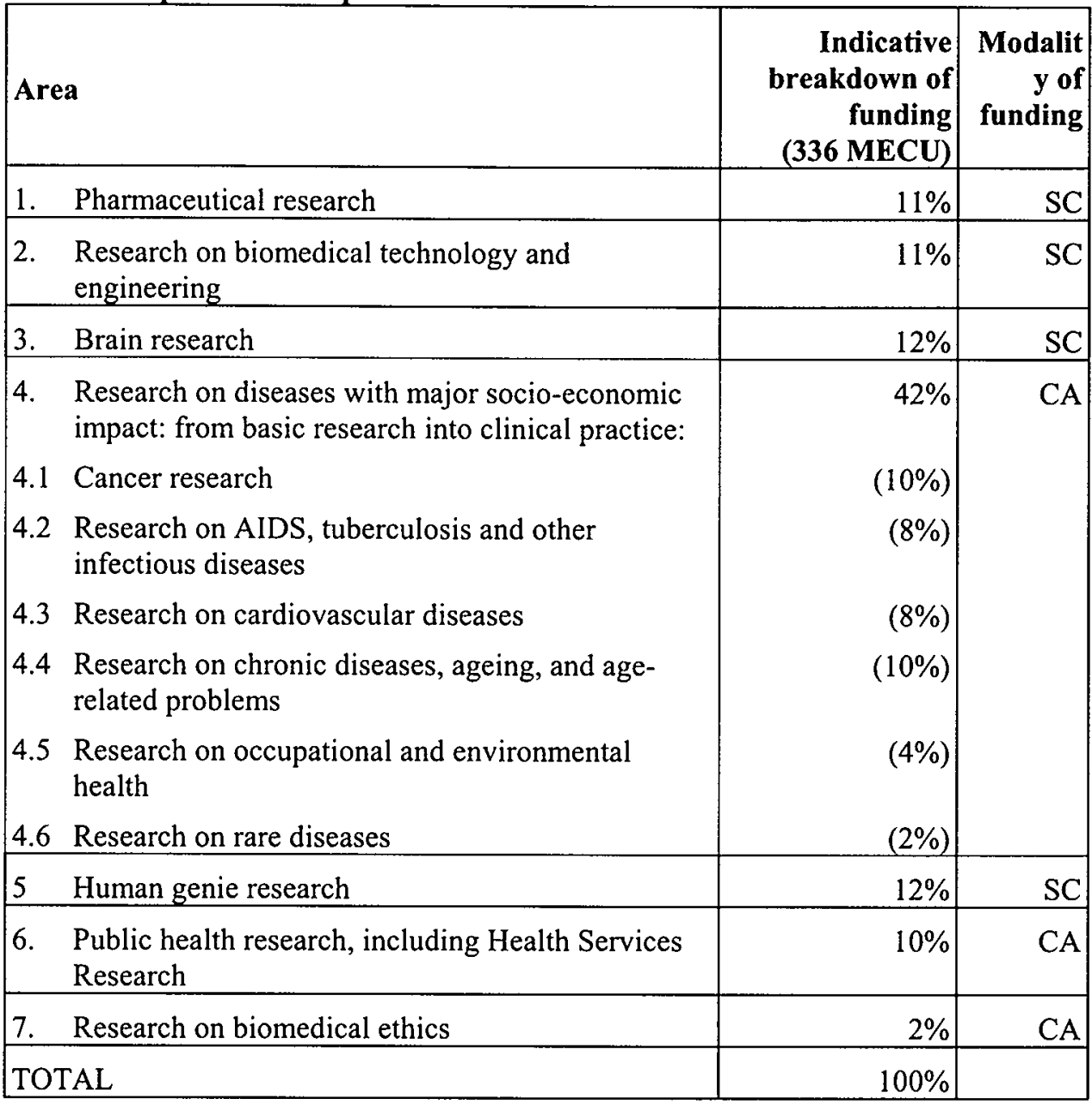

The increase in funds in BIOMED 2 opened the way for direct financial support of research activities. But the shift of emphasis from Concerted Actions (CA) and centralised facilities to shared cost actions (SC) in BIOMED2 occurred only in some research areas, namely, pharmaceuticals, biomedical technology, and brain research. The concerted action remains the predominant form of funding in research concerning diseases with major socio-economic impact and public health, including health services research.

How were the MHR-programmes evaluated? Here, it is interesting to pay brief attention to the Maynard report, which contained an evaluation of the fourth Medical and Health Programme. The report stated that 
"the Panel is impressed by progress that has been made in the beginning of new "collegial networks" of research workers across Europe, in the initiation of some Community data bases and in the opportunities for short-term training. Many of the participants have indicated that the creation of networks is a very limited objective. The Panel in interpreting the Council Decision of 1987 which laid out the objectives of the Programme, has assumed that increased collaboration was a means, rather the ultimate objective of MHR4. (....) They do not consider it adequate for what such research will surely be expected to do for the people of Europe". ${ }^{51}$

In short, the report stated that scientific achievements were insufficient, and that concerted actions were of only limited value.

Maynard and his colleagues also argued that political and financial factors influenced the outcome of MHR4. They saw the lack of an explicit Community competence in the health field as a major factor constraining both the design and implementation of research in med0icine and health. It was suggested that decisions about the programme's activities should not be determined only by Ministries of Research and Industry. Ministries responsible for health should also be involved in decisions about funding and the direction of the research programme. Furthermore, the principle of not funding research, but only the cost of bringing the teams together and the review system was questioned. A gap was identified between the level of Community research funding and the growing research requirements of EC legislative action in various policy fields including drug registration. In addition, the report stressed the need to determine the cost-effectiveness of health promotion as well as prevention, treatment and rehabilitation programmes. It indicated that financing of multi-centre studies with common protocols and databases should be stimulated. The use of common protocols with the rapid recruitment of patients for the evaluation of new technologies would improve the efficiency of health care systems. Common procedures could also facilitate the collection of health service data and epidemiological information across the Community, essential for prevention of chronic diseases, performance of clinical trials, and new forms of health care.

A second evaluation report, the so-called Laredo report ${ }^{52}$, studied the processes of collaboration (i.e. the research networks) under the MHR4. The report emphasised the achievements of the modest EC support in terms of an investment in lasting scientific infrastructures. Despite the limited EC financial support, there was wide and active participation on the part of research teams. The report concentrated on 3527 teams involved in MHR4, organised into a total of 117 concerted actions with an average of membership of 30 teams. It examined the chief characteristics of those teams, the results its members expected, and their opinions on the programme, its effects and its limitations. The report highlighted the complex process of building these networks and stated, for example that

"Each concerted action brings together an average of thirty teams belonging both to national systems with specific characteristics and to different professional environments. They need to get know each 
other, to define a common language and to ensure that their data are comparable. These may appear to be simple problems but they have major practical implications: harmonisation of terminology and laboratory practices, setting up of "common services" or "central facilities", etc. This structuring phase can take several years, and the time needed is almost always underestimated. (....)

The future of the Community intervention in medical research will depend heavily on the political answer to these questions since in the final analysis this programme produces...complex networks which cannot pay for themselves from the initial scientific results that they were set up to produce, thus raising the question of how to keep them in operation on a lasting basis. These and not the question of financing research on a cost-sharing basis, are the reasons warranting the opening of discussions on a Community form of NIH (National Institute of Health)" ${ }^{53}$.

The budget allocated to biomedical and health research has been increased from 65 million ECU in MHR4 (1987-1991) to 336 million ECU in the BIOMED 2. The BIOMED 2 went beyond co-ordination of research and directly funded research projects in some areas. Despite the increase in the level of funding, the oversubscription (or underfunding) increased significantly as well. So, the 1996 five-year assessment report of the BIOMED programme, which addressed this problem, called for a larger budget in the new programme to reduce wastage of many excellent initiatives. According to the report, the problem of insufficient national resources increased over the years. Scientists began to see the EC as an important additional source of funding. The problem of underfunding was particularly serious in biomedical technology, brain research, cancer research and cardiovascular research. As far as the health care contributions of the programme were concerned, the report showed that therapeutics was the primary goal of the projects, followed by epidemiology and disease prevention. Genetics, cancer, and AIDS represented the main areas of medicine that may benefit from the achievements produced by the programme. Finally, participants considered the transfer of knowledge to other countries, the creation of networks, national comparisons and development of new technologies to be the main outcomes of the BIOMED-funded proposals ${ }^{54}$.

The next topic concerns the EC co-ordination of national activities in the field of health services research (HSR) which started in the third programme. The inclusion of this research field reflects the intensification of earlier efforts in most Member States during the eighties to develop quantitative and qualitative methods - such as use of indicators, cost-benefit, cost-effectiveness analyses, surveys of need, evaluation research, and policy analysis - to support good choices by health policy makers as well as managers of research programmes. 


\subsection{The co-ordination of projects in the field of Health Services Research (HSR)}

The third EC medical and health research programme (1982-1986), in fact the first large co-ordination programme, was already oriented to optimising the costeffectiveness of health care through the appropriate use of health resources. The coordination of efforts in HSR was promoted with a view to defining priorities for health and health care policy. COMAC-HSR, the advisory board for HSR composed of national representatives and scientific experts, stated in this respect:
"Health services research is concerned with how health services work, are managed, financed, and planned, with a view to deciding priorities in health care. It is thus the basic tool for the development of methods, of formulating objectives, and of evaluating results. Health services research is concerned with the structure, economics, organisation, and outcome of health services and their relationship to social and environmental circumstances ".55

HSR places health and disease in a larger context that accounts for social, economic, and cultural factors. Research covers a wide range of subjects: the assessment of health status and needs of the population; the organisational structure, the planning, the resources, the delivery, and the evaluation of health services in terms of input, process and outcome. Collaborative research is often multi- and interdisciplinary work, involving, for example, epidemiology, social medicine, demography, policy science, health economics and law. In this type of research a common problem or a set of problems is investigated from the perspective of different disciplines, with the results brought together at the end. Although the same methods can be applied to similar problems in different countries, the findings and solutions are unlikely to be the same across different social, economic, political and cultural realities.

In the remaining part of this section we briefly discuss seven examples of concrete HSR-projects, six from MHR4 (1987-1991) and one from BIOMED 1 (1990-1994).

The six MHR4 projects were summarised in an overview volume ${ }^{56}$, which also serves as the basis for the following description.

The first project dealt with prevention. The 'EC Working Group on Health Services and Avoidable Death' undertook a standardised collection of mortality information for 17 potentially preventable causes of death for all Member States of the Community. It also covered information on the regions within the Member States. These 17 groups were agreed as indicators to measure the outcome of primary and secondary prevention and curative care. Three causes of mortality (lung cancer, cirrhosis of the liver, and motor vehicle accidents) were predominantly amenable through primary prevention at a national level. For the other diseases (tuberculosis, cervical cancer, cancer of the cervix and uterus, Hodgkin's disease, heart disease, childhood respiratory disease, maternal and perinatal mortality, etc.), ineffective treatment as well as primary and secondary prevention could be provided by health services. A significant variability in mortality rates both between Member States as well as within Member States was found and documented in the European Community Atlas on Avoidable 
Death $^{57}$. Future research plans include further work on the causes of the variations discovered. The role of health services could not sufficiently be linked with mortality differences so far.

The second example is directed at care delivery systems. Throughout the Member States, populations are expected to age remarkably in the forthcoming decades. The concerted action on 'Care Delivery Systems for the Elderly' thus focused on a problem that is expected to remain for a long time in the European public health agenda. The project investigated the situation of the elderly in Member States by survey methods. It concerned the pathways of the elderly through different settings of care, and analysed public policies with respect to this group ${ }^{58}$. Significant differences exist between the progress of ageing and its future development between the European societies. Similarly, differences were identified with respect to the cultural settings that to a great degree determine the amount of informal care available to the elderly. In general, the need to improve care systems was emphasised. For some northern Member States this concerned more the contributions of informal care, in some southern Member States more that of community services.

The third example is concerned with the field of health care organisation. It deals with a new information tool that is relevant for management and evaluation in hospitals. The concerted action 'Use of Diagnosis Related Groups (DRGs) to Support Hospital Sector Management in the EC' investigated data needs and procedures to classify European hospital patients into DRGs. Such classifications allow for the detailed measurement of the case-mix of patients treated in hospitals. Most Member States had started DRG experiments by the time the project began. The standardisation of DRG information, exchange on the experiences of DRG production and first explorations of DRG use for purposes such as internal management and quality assurance were major achievements of this project ${ }^{59}$. A significant variability in length of stay* in hospitals was reported both between and within Member States, pointing towards differences in treatment practice as well as in care efficiency. DRG use was investigated in more detail in a follow-up concerted action.

The fourth example is a project that dealt with the 'Methodology of Economic Appraisal of Health Care Technology'. It was a contribution to the research field of health technology assessment. The project aimed at the standardised development of research tools and at the improvement of evaluation studies on the European level. More standardised economic evaluations would enable a better division of labour between the Member States in the assessment of health care. Three technologies featuring different states of their life cycle were investigated by the project: laser technology, heart surgery, and pre-natal screening. Approaches that added contributions on different evaluation aspects were used as well as comparative approaches. A number of agreements on standards for future evaluations were

* Case-mix, standardized average length of stay 
achieved. For a better link with health policy and other decision making, an evaluation handbook for decision-makers was published ${ }^{60}$.

The fifth example is also a contribution to the research field of health technology assessment and more generally to the analysis of the regulatory mechanisms used in European countries to control the introduction and use of health technologies. Medical technology has been of enormous benefit in improving the quality of health care. It has, however, raised many issues about how society can afford to pay for these oftenexpensive developments and about associated ethical problems and their social impact. This project concerned the effect of these issues on the rate of diffusion of three technologies across the twelve EC countries and Sweden (not an EC member then), from the time of their introduction up to 1990. The three technologies were: prenatal screening for metabolic or anatomical disorders, especially Down's syndrome and neural tube defect; treatment of kidney stones by lithotripsy and endourological procedures; and kidney, heart and liver transplantation, with the attendant problems of organ donation and procurement. The results of this project have been published in three volume series ${ }^{(1)}$.

Three conclusions emerged quite clearly from this project: that the medical profession, as individuals and as a group, has been the dominant influence over the introduction and diffusion of these medical technologies; that the role of consumers has been surprisingly weak considering that several technologies involved major ethical issues about life, death and disability; and that in no country in this study was full central or governmental control over all the technologies attempted or achieved. However, The Netherlands and Sweden stand out as having gone further in this respect than others. Even accepting that the diffusion of medical technology will never be an entirely rational process, it appears that the combination of the three key factors makes the introduction and use of medical technology to be somewhat more successfully controlled in The Netherlands and Sweden. The acceptance of the government's role in undertaking technology assessments and the need for broad planning agreements played a major role in this respect.

The sixth example is the study on 'Economic Aspects of AIDS and HIV Infection ${ }^{62}$. Because economic impacts are closely linked with the epidemiological development of this infectious disease co-operation emerged with another project namely, the concerted action on Statistical Analysis and Mathematical Modelling of $\operatorname{AIDS}^{63}$. The collaboration contributed to research requirements formulated in a 1989 resolution of the EC Council of Health Ministers on the fight against AIDS which had, among others, called for 'analyses of the socio-economic consequences and future projections and scenarios'. EC scenario analyses on need for hospital beds and health care expenditures for patients with full-blown AIDS were developed. A follow-up concerted action, 'Multinational Scenario Analysis Concerning Epidemiological, Social and Economic Impacts of HIV/AIDS on Society' was started.

The seventh and the most recent example is a project concerned with "Health Care and its Financing in the Single European Market" ${ }^{\prime 64}$. This project aimed to: identify aspects in health care financing which are of relevance in a single market (including 
differences in health care and its financing in EC Member States which set incentives for interaction between systems); to analyse cross-border care with respect to its legal regulation, empirical extent, financing; and to investigate possibilities for alternative organisat; and to explore and analyse current and future impacts of the single market on health care financing, including impacts on organisation and performance of health care. Overall, the research results indicate that a single European health care system cannot be expected to develop within the coming years, independently of whether this is desirable or not. Nevertheless, the results show that we definitely have to deal with a European dimension of health care. This has been generally recognised in the field of pharmaceutical products, but it is also relevant for the other areas discussed. The European dimension is highlighted by the impact of economic integration policy on various parts and aspects of the operation of health systems, and by the increasing need for comparison, (including comparing the effects of the ongoing health care reforms). It is also highlighted by the increasing challenge of interaction between health systems, especially by cross-border care.

The above illustrations of HSR projects in the EC are, and can only be, selective - just seven out of a large number of projects were presented. A number of conclusions can be derived from these illustrations. HSR is a field of explicit relevance in the European context, and the EC provides a framework for its development. As in several other fields of EC activities, HSR benefits from international comparisons of national experiments and evaluations. HSR methodologies are improved by the discussions on standardisation and quality at the international level. For some issues, economies of scale can be realised at the European level as opposed to the national ones. Comparative and additive approaches in an EC context often allow a more clear and comprehensive elaboration of pending HSR issues. National analyses of the organisation and the performance of health services may benefit when experiences from other health systems are systematically integrated. In the course of time, a common understanding as well as a common body of knowledge about the EC health care systems may develop, and at some point establish a Community HSR culture may be established. Last, but not least, the concerted actions also emphasised the link with decision-making in health care and in health policy, thus moving research closer to the needs of our societies.

Next we focus on the Maastricht commitment to public health (Article 129), its revision by the Amsterdam Treaty (Article 152) and we discuss the implications of the new provisions to policy development.

\section{Public Health Policy after Maastricht and Amsterdam}

The importance of a Community "contribution to the attainment of a high level of health protection" is well demonstrated in the preamble of the Treaty on European Union. Article 3 , which sets out the Community policy agenda and related activities. Article 129 then sets out the general framework for Community action on public health. It is worth looking in some detail at what these provisions say (see also annex 1). 
Article 129 sets a clear policy objective. Community action in this field should be directed towards "ensuring a high level of human health protection". Furthermore it reads:

\section{"Community action shall be directed towards the prevention of diseases, in particular the major health scourges, including drug dependence, by promoting research into their causes and transmission, as well as health information and education".}

Importantly, public health action is very well delineated: incentive measures are adopted through a co-decision between the Council and the Parliament, and recommendations are adopted through qualified majority vote in the Council. The explicit ruling-out of harmonisation measures, for example directives or regulations, strongly limits the scope for changing national policies. This is hardly surprising after reading the previous chapter. We also saw a similar trend in the debate, discussions and symbolic deliberations of governments on harmonisation and convergence in social policy and the Social Protocol/Agreement. Article 129 leaves the primary responsibility for the resolution of European health policy problems at the national level. In other words, the "right to health care" is not yet recognised at the Community level ${ }^{65}$. Nevertheless, the article's provision that "health protection requirements shall form a constituent part of Community's other policies" may help better place public health on the general policy agenda of the EC. Unfortunately, it does not define how this objective will be enforced or which initiatives the EC institutions will take.

However, the existence of the new powers, as expressed in the new Treaty, generated a need for discussion of potential policy activities and programmes. The first policy documents issued by the Council, the Commission and the European Parliament, may help us to explore the intentions of the main institutions involved and the new possibilities for public health policy development as well.

In May 1993, the Council of Health Ministers adopted a resolution on "future action in the field of public health" ${ }^{\prime 66}$. The resolution stated explicitly that,

"public health policy as such, except in cases where the Treaties provide otherwise, is the responsibility of the Member States".

Community action should therefore continue to put emphasis on prevention and so should the Commission in its proposals for Community measures and activities.

What may be seen as new is that the Health Ministers recognised that there was a need to develop a long term approach to the planning of public health activities to ensure coherence and continuity. Accordingly, future policy activities would first have to be part of a long-term plan (of about six years), which would include the indication of their general objectives, areas of activity, resources and review clauses. Medium term work programmes then could be drawn up and organised for a period of about three years.

Health Ministers went further, setting out the broad criteria for selecting the areas of activity. The Commission in presenting its new initiatives and programmes to the Council would have to argue: that a significant health problem exists and appropriate 
preventive actions can be taken; that Community-added-value in relation to national action is involved; that the activity supplements or promotes other Community policies, including the smooth operation of the internal market; and that the activity is consistent with those of the other international organisations, such as the World Health Organisation.

In preparing its proposals, the Council would assist the Commission through a highlevel committee of representatives of the Member States. Finally, Health Ministers recognised the fact that some of the most important health-related aspects are dealt with by other Councils, (for example, in the fields of research, the environment, the safety and health of workers and the free movement of goods, services and persons). Thus, they also recognised the need to set up mechanisms, which could direct their attention to matters of particular importance for health in good time and enable them to bring their influence to bear on such matters. Nevertheless, they did not specify either the mechanisms nor the means.

In October 1993, the European Parliament and its Committee on Environment, Public Health and Consumer Protection issued its report on "public health policy after Maastricht", including its views, priorities and proposals for Community action. The Committee urged the Commission to provide wider consultation procedures, including not only the national representatives, but also health professionals, care providers, national health authorities and non-governmental organisations. The Committee also urged the Commission to review the current health competencies of its various Directorates General (primarily, III, V, VIII, XI, XII, and XIII) and appoint one of its Members to be responsible for the co-ordination of all aspects of health policy, including research.

The Committee report went on to make several proposals for Community action, including calling, for example, the Commission to: establish an epidemiological investigation service; collect, analyse and disseminate data on notifiable diseases; encourage exchange schemes for health professionals; encourage greater use of generic pharmaceuticals; execute new activities on health promotion and education campaigns focused on drug abuse, and accidents, and also on vaccinations and screening; implement the European Parliament's resolutions of 19 January 1984 on a European charter of patients rights and 16 November 1984 on patients' health cards; and publish regular reports on the "State of Health" in the Community in line with the existing "State of the Environment""

The Commission, in particular the public health unit of DGV, sought to capitalise on the new Treaty powers and the strategic deliberations of the Council and Parliament. In response to the long term planning approach of Health Ministers, the Commission published its first communication on a five year framework for public health action as soon as November $1993^{68}$. As it was asked by the Council, the document put emphasis on prevention activities, and also attempted to ensure continuation of existing programmes and reach prior consensus on new programmes and funds. In total, the document proposed eight specific programmes to be introduced on the basis of Article 129: health promotion, education, and training; cancer; drugs; AIDS and other communicable diseases; health data and indicators, and monitoring and surveillance of 
diseases; intentional and unintentional accidents and injuries; pollution-related diseases; rare diseases. In response to the recommendations made by the European Parliament, the Commission also proposed to establish a system of close co-operation and effective co-ordination between Member States in the field of surveillance and epidemiological control of communicable diseases ${ }^{69}$.

Although a planned and multi-annual public health strategy was discussed, what actually resulted was somewhat piece-meal in character with small, under-financed specific programmes. Furthermore, the approval of each specific programme soon became subject to the complex co-decision procedure between the European Parliament and the Council. For example, the general multi-annual framework programme for research is adopted through the co-decision procedure as a whole. Moreover, it is not clear how health requirements in a given area of policy were integrated. Criteria to judge success or failure had not been introduced.

The Commission began to report on the state of health in the EC in co-operation with the World Health Organisation. According to the first publication, health was improving in all countries, children were healthier and adults were living longer. There were still major problems and the main illnesses and indeed causes of premature death in adulthood were still the big ones - heart disease, stroke, cancer and accidents, while notified cases of AIDS were rising in all EC countries ${ }^{70}$. As for the state of women's health in the EC, the second report published showed that women enjoyed a high level of health in the Community as measured by a variety of health indicators and live, on average, over 6 years longer than men. Across all ages, the most frequent causes of death among women were diseases of the circulatory system and cancer. With the ageing of society, however, osteoporosis is becoming a growing concern ${ }^{71}$ To reduce death and disability, both reports suggest that the health services and other sectors with activities affecting health need to take preventive action directed at individuals and, through public health measures, at the population at large.

As many Community policy areas have an impact on health, the Commission also started the annual publication of a report on the integration of health protection requirements in Community policies ${ }^{72}$. The publication confirms once again that the most important health-related developments take place in social policy, internal market, agriculture, food and fisheries, research and development, environment and energy, transport and international co-operation.

In the meantime the cattle brain disease, BSE, and the human illness, CreutzfeldtJacob Disease, CJD, has brought into sharp focus the important shortcomings of both Governments and the Commission to protect the health of the citizens in the single market. In the event, the Commission set up a group of Commissioners on food health, chaired by Jacques Santer, the President of the Commission himself. A distinction of responsibilities was drawn between Directorates dealing with food legislation (Industry and Agriculture) and the Directorate dealing with the assessment of public health risks and inspection of foodstuffs. The Commission placed all the relevant scientific committees under its Directorate General on consumer policy (DG XXIV), which also became responsible for consumer health. 
The President of the Commission blamed the contradictions of the system itself, which do not allow for a full assessment of the effects of the single European market on public health. For this purpose, he called for the establishment of an independent European Agency on Foods and Drugs Administration equivalent to the United States Food and Drug Administration ${ }^{73}$.

It is beyond doubt that issues of food safety and inspection are likely to remain high in the policy agenda of the Community.

Under the threat of censure by the European Parliament, the Commission declared health to be a European priority and produced a proposal to change Article 129 during the Intergovernmental Conference discussions about the Treaty of Amsterdam ${ }^{74}$. As a result, article 129 was revised and appeared as article 152 in the Treaty of Amsterdam, signed in October 1997.

As we can see in Annex two, important health and safety matters, which were previously dealt with by Ministers for Industry or the Internal Market in the Council, now fall within the competence of Health Ministers. According to a new paragraph 4(a) (of article 129), Health Ministers in the Council will adopt the legal measures related to organs and substances of human origin, blood and blood derivatives. It is worth noting that this new paragraph reflects the importance attached to these health concerns by the Dutch Minister of Health, whose government hosted the Intergovernmental Conference.

In addition, some measures in the veterinary and phytosanitary fields, which used to be classed as purely agricultural, will now be treated as human health issues. This step reflects the recent concerns over BSE. Apart from these legal measures, Community action is again clearly limited to incentive measures dealing with major health scourges, research into their causes, their transmission, their prevention as well as health information and education.

By the year 2001 most of the current public health activities in the fields of prevention, health information and education will have expired. Discussions concerning the future of biomedical and health research as a part of the fifth framework programme for research are under way ${ }^{75}$. Similarly, suggestions for a multi-sectoral approach to formulate public health requirements for other Community policies have started to appear.

The Dutch Presidency has already launched the debate over the future framework for public health action and presented a paper as a basis for discussion at the Health Council on 5 June $1997^{76}$. The document argues for a broader rather than a narrow Community health protection strategy and stresses the need for a comprehensive plan with regards to future action. As to the priorities of the new framework, the document suggests that the focus should be on wide and unexplained health variations that exist between countries or regions. Secondly, the new framework should focus on diseases (and health challenges), which are important in all or most EC countries, or are "exported" from one country to another, or are of particular relevance to EC legislation and programmes. In developing action to prevent diseases, it suggests that EC action should pay particular attention to communicable diseases, associated with 
the free movement of consumer goods and services and of people; health and safety at the work-place and in traffic; lifestyle and behaviour-related health; and rare and emerging diseases. In addressing health variations, the document indicates the use of structural funds, research programmes and Trans European Network programmes.

To ensure and add legitimacy to the final policy document on the New Framework for Public Health, the document calls for wide and regular consultations involving the expertise and opinion of professionals and professional agencies, social partners, statutory and voluntary bodies, leading, for example, to a Green Paper on public health. As to the financial implications, it indicates the regrouping of existing public health budgets and tentative calculations of an additional budget.

What judgement, then, one can come to about the force and likely impact of the new Treaty provisions on public health? We may say that the new provisions mark the first formal recognition of the fact that Community policies do have important implications for the health of European citizens. This is particularly true of health and safety regulation. As we discussed in chapter five, health concerns have been addressed because, had they not been, they would have acted as a barrier to trade, with Member States possibly using health arguments to block the import of foreign goods.

However, the BSE crisis revealed the inadequacy of the system in protecting the health of European citizens. It also revealed that health concerns have been treated in many cases more as industrial or agricultural concerns than in their own right. After the Amsterdam Treaty, important legal measures for health and safety fall into the responsibility of Ministers for Health. It remains to be seen how the key players, (the Commission, the Council of Ministers, and the European Parliament) will change to improve the regulatory frameworks of the single market for the benefit of health of European citizens.

\section{Conclusions}

Our first conclusion is that the EC was involved in public health matters long before it was given a formal mandate to undertake such activities in the Maastricht Treaty. The first disease-related policy programme, 'Europe against cancer', was set up under the initiative of the European Council in 1985 and in particular that of the French President Francois Mitterand. The involvement of the Heads of State and Government thus began to play a significant role in public health policy initiation at the Community level.

Since the early 1980s National Health Ministers have been meeting to discuss the problems they have in common, for example, cancer and AIDS. We can draw some conclusions on both disease-related programmes. Our first conclusion is that the legacy of the past is full of conclusions, resolutions, ad hoc political mandates to the Commission, and the availability of only a modest amount of financial resources. The programmes are characterised by rhetoric deliberations, symbolic actions and pragmatic exercises with limited priority setting in the field of prevention. 
Activities eventually included the supporting of conferences, workshops, information campaign material, networks, the collection and analysis of comparable epidemiological data, and also the development of few legal binding measures. Their existence increased the impetus of the co-ordination of the biomedical research activities, carried out as a part of the EC's Framework programmes for research.

The two programmes (cancer and AIDS) also highlight the political difficulties connected to the initiation of public health activities by the Community. Their history shows the reluctance of the governments to give the Commission a strong position in health policy affairs, particularly so when matters of organisation and funding of health care were discussed. This is not surprising, however, as chapter six showed - the Community has faced many difficulties in developing a more active role over social security and health care. The Commission on its part had to manoeuvre very strategically in order to respect the principle of subsidiarity and make real progress. The strong emphasis upon co-ordination of national prevention strategies can only be understood against this political background.

If we look back to the history of the scientific co-operation between the Member States, our main conclusion is that the Community has significantly increased its efforts, over the last twenty years, to stimulate research in a broad sense. We also see here a similar pattern of policy development as in the public health field. The Single European Act in 1987 brought science and technology under the formal competence of the Community. Yet, the first Framework programme for research was launched before this time and there already was a budget for R\&TD. Despite this, it took a long period of political manoeuvring, argument, negotiation and compromise to place research and technology under the formal competence of the Community.

In comparison to other Community policies, including public health, research was given priority in budgetary terms. After agriculture and regional policy, it became the most important new Community policy. That Europe lacks behind the industrial and technological capacity of the USA and Japan was always an important argument in developing Community Framework programmes and new research activities. Industrial competitiveness was the main priority of this policy and its Framework programmes, until the Maastricht Treaty.

The changing spending pattern of the Framework programmes reflected the perception that the Community had to stimulate ICT and industrial RTD. However, the share of life sciences and technology, of which the medical and health research programme formed a part, has steadily grown from $5 \%$ in the first Framework programme to 13 percent in the fourth programme.

If we look back in the history of the medical and health research programmes, our main conclusion is that in comparison to public health activities, a relatively well established institutional structure such as the Framework programme helped to better articulate the issues and thus focus attention on European collaboration in medicine. However, the argument that Europe had to match the performance of an organisation such as the US National Institute of Health did not considerably increase the Community financial opportunities in biomedicine research. The principles of Community co-ordination were in dispute, the financial rules not clearly defined or 
constantly redefined and the objectives hotly contested within the Framework programmes. The emphasis on financial modes such as the concerted action can only be understood against such a political background. Nevertheless, the Framework programmes served to focus debate on Community scientific collaboration in health, and thus investing in it where this will be more cost-effective than national actions (or inaction).

The objective of the Maastricht Treaty provisions on public health was not to define a health policy strategy, which Member States would be compelled to follow, but to move the issue of health up the political agenda of the Community. The new public health provisions have already facilitated incremental additions to public health activities and research programmes, and have added legitimacy to the existing Community policy responses in the field of prevention, health information, education and research.

Given the constraints and limitations of the Community budget we do not expect a considerable increase in the Community funds for public health. The new provisions may potentially alter the legacy of an ad hoc and segmented approach to health action, and may eventually lead to the institutionalisation of a planned framework for the setting of priorities, the means of financing and delivering public health programs. Under these circumstances, even modest financial increases might make a significant difference in relation to a new policy are such as public health.

We may also expect that the Community will have a part to play in improving or developing systems for health data collection and transmission. It may also have a part to play in promoting research, which explains differences in mortality, morbidity and risk factors between and within different EC countries. These differences could be related to several factors, including access to health care and policies of health promotion and disease prevention ${ }^{77}$.

There was a curious contradiction between the relatively limited Maastricht commitment to public health and the considerable Community involvement in important health and safety matters. This has been manifested as demands on consumer and environmental protection, and on health and safety in the workplace. The contradiction is further exposed when we add to it the EC's role in regulating new high technologies, for example, the controversial biotechnology affairs. While Health Ministers were declaring that health care was their domain, ethical, commercial and research issues of new high technologies were being debated daily in committee rooms in Brussels.

The Maastricht commitment to extend health co-operation fell well short of defining a common EC health and safety policy. The BSE crisis revealed that health concerns have been treated in many cases more as industrial or agricultural concerns than in their own right. The revision of the public health article by the Amsterdam Treaty can thus be seen as a response to this fact.

It remains to be seen how the key players involved, the Commission, the Council of Health Ministers and the European Parliament, will change or improve European and 
national legal, administrative and policy regimes to regulate the single market for the benefit of health of the European citizens.

\section{Chapter Seven References}

1. Jacques Delors, The struggle against a solitary society: keeping vigilant against indifference, in Claude Jasmin and Gabriel Bez (eds) : Villejuif : International Council for Global Health Progress, 1993, p 275.

2. Speech by Jacques Santer, President of the European Commission, to the European Parliament, Debate on the report by the Committee of Inquiry into BSE, Strasbourg, 18 February 1997.

3. Report from the Commission to the Council on the conclusions of the high level express and on the state of work in progress at Community level in the fight against cancer, COM (86), 150 final, Brussels 7 Mars 1986.

4. 'Europe against cancer' programme, Proposal for a plan of action, 1987 - 1989 including a proposal for a Council Decision on informing the general public and the training of members of the health professions, COM (86) final, OJ No C50/1, 26.2. 87.

5. Resolution of the Council and the representatives of the Governments of the Member States, meeting within the Council, of 7 July 1986, on a programmeme for action of the European Communities against cancer, OJ No 184/19, 23. 7. 86.

6. Decision of the Council and of the representatives of the governments of the Member States within the Council, of 21 June 1988. OJ No L 160/52, 28.6. 1988.

7. Communication from the European Commission to the Council, the European Parliament and the Economic and Social Committee of 8 May 1990, regarding the "Europe against cancer" programme. Report on the implementation of the first plan of action $1987-1989$. Social Europe 1/921, Luxembourg: Office for Official Publications of the European Communities, 1991.

8. OJ No L $359,8 / 12 / 89$.

9. OJ No L137, 30/5/90.

10. OJ No L 298, 17/10/ 1989.

11. OJ C $189,26 / 7 / 89$

12. Michel Richonier, Following the U.S. example: How the European Community went into public health in Liam Fahey's (ed), Winning in the New Europe, taking advantage of the single market, Prentice Hall, 1992, p. 219.

13. Michel Richonier, Following the U.S. example: How the European Community went into public health in Liam Fahey's (ed), Winning in the New Europe, taking advantage of the single market, Prentice Hall, 1992.

14. M. Mckee, The influence of Europe on national health policy, in L. J Gunning-Schepers, G. J. Kronjee and R. A. Spasoff (eds), Conference report on the Fundamental questions 
about the future of health care, Netherlands Scientific Council for Government Policy, Sdu Uitgevers, The Hague, 1996.

15. OJ No L $137,30 / 5 / 90$

16. Decision No 66 of the European Parliament and of the Council of 29 March 1996 adopting an action plan to combat cancer within the framework for action in the field of public health (1996-2000), 0J No 95, 16/4/96.

17. Prevention No 1/1996, Progress in Community Public Health, European Commission, Directorate General V, Directorate F, Public Health and Safety at Work.

18. P. Fasella, The EU role in innovative health research: science-driven or problem solving?, in D. Evered, R. Kroes and E.C Klasen, Innovative research and appropriate health care for the citizens of Europe, European Commission, EUR 17786, 1997, pp 14-21.

19. Communication from the Commission on the fight against AIDS, (COM) 63 final, 11 February 1987.

20. Resolution of the European Parliament on an emergency programme of research into and measures to combat AIDS disease, OJ No C 46, 20/2/1984

21. Christa Altenstetter, European Community -Wide Efforts to address AIDS, Mannheim Centre for European Social Research, 1992.

22. Resolution of the Governments of the Member States, meeting within the Council, of 29 May 1986, on AIDS, OG No C 184, 23/7/86.

23. Conclusions of the Council and the Representatives of the Governments of the Member States, mecting within the Council of 15 May 1987 concerning AIDS, OJ No C 178 , 7/7/87.

24. Communication of the Commission, Community action against AIDS in 1987, COM(88) 268 final, 17 May 1988.

25. Christa Altenstetter, European Community -Wide Efforts to address AIDS, Mannheim Centre for European Social Research, 1992.

26. Conclusions of the Council and the Ministers for Health of the Member States, meeting within the Council, concerning AIDS and the place of work, OJ No C 28, 3/2/89.

27. Conclusions of the Council and the Ministers for Health of the Member States meeting within the Council of 16 May 1989 regarding the prevention of AIDS in intravenous drug users, OJ No C 185, 22/7/89.

28. Conclusions of the Council and the Ministers for Health of the Member States meeting within the Council of 16 May 1989, OJ N0 C 185, 22/7/89.

29. Conclusions of the Council and Ministers for Health of the Member States meeting within the Council, on the improvement of the general system for collecting epidemiological data, including the application of the new definition of AIDS cases, OJ No C 185, 22/7/1989. 
30. Conclusions of the Council and the Ministers for Health of the Member States meeting within the Council, regarding future activities on AIDS prevention and control at Community level, OJ No C 185/1989.

31. Resolution of the Council and the Ministers for Health of the Member States, meeting within the Council, on the fight against AIDS, No C 10, 16/1/90.

32. Decision of the Council and the Ministers for Health of the Member States, meeting within the Council, adopting a plan for action in the framework of the 1991 to 1993 'Europe against AIDS' programme, OJ No L175,4/7/91.

33. Christa Altenstetter, European Community - Wide Efforts to Address AIDS, Mannheim Centre for European Social Reseach, 1993.

34. Report from the Commission on the implementation of "Europe against AIDS" plan of action in 1991- 1992, COM((93), 42 final, Brussels, 10 March 1993.

35. Commission report on the implementation of "Europe against AIDS" action plan in 1993, COM (94), 525 final, 25. 11. 1994.

36. European Parliament and Council Decision No 1729/95/EC on the extension of the "Europe against AIDS" programme, OJ No L 168, 18/7/95.

37. Commission report on the implementation of the "Europe against AIDS" action plan 1994-1995, COM(96) 720 final, Brussels, 15.1.1997.

38. ibid.

39. Decision No 647/96/EC of the European Parliament and of the Council, adopting a programme of Community action on the prevention of AIDS and certain other communicable diseases within the framework for action in the field of public health (1996 to 2000), No L 95, 16/4/96.

40. M. André, "Research and technological development policy", European documentation, periodical 2/1988, Office for official Publications of the EC, Luxembourg, 1988.

41. P. Braillard et A. Demant, "EUREKA et l' Europe technologique", Collection Savoir, Bruylant Bruxelles, L. G. D.J - Paris, 1991.

42. Luca Guzzetti, A Brief History of European Union Research Policy, European Commission, Directorate General XII, Luxembourg 1995.

43. ibid.

44. EC, "The European report on Science and Technology Indicators", Figure 9.2, Office for Official Publications of the EC, Luxembourg, 1994.

45. P. Braillard et A. Demant, "EUREKA et l' Europe technologique", Collection Savoir, Bruylant Bruxelles, L. G. D.J - Paris, 1991.

46. Commission of the EC, First Report on the State of Science and Technology in Europe, COM (88) 647 final. p. 32. 
47. M. Theofilatou and R.Leidl, "Public Health Policy and Health Services Research in the European Union", in Laaser U, de Leeuw E, Stock C (eds), "Scientific Foundations for a Public Health Policy in Europe", Juventa Verlag Weinheim und Munchen, 1995.

48. Council Decision of 23 April 1990, concerning the framework programme of Community activities in the field of research and technological development (1990 - 1994), OJ NO L $117 / 28,8.5 .90$.

49. Decision No 1110/94/EC of the European Parliament and of the Council of 26 April 1994, concerning the fourth framework programme of the EC activities in the field of research and technological development and demonstration (1994 to 1998), OJ L 126, 18 May 1994.

50. André-Emmanuel Baert, History of Medical Research at EC level, in idem (ed), European Union, Biomedical and Health Research, The BIOMED I Programme, IOS Press, p 31.

51. A. Maynard, D, Frederickson, S. Garattini, H. Makela, R. Mattheis and M. Papadimitriou, Evaluation of the fourth Medical and Health Research Programme (1987-1991), Research evaluation - report no. 44, Commission of the EC, Luxembourg, 1990.

52. P. Laredo, B. Kahane, J.B Meyer, D. Vinck, The research Networks built by the MHR4 Programme, Commission of the EC, Research evaluation, Luxembourg, 1992, p vi, p 201.

53. P. Laredo, B. Kahane, J.B Meyer, D. Vinck, The research Networks built by the MHR4 Programme, Commission of the EC, Research evaluation, Luxembourg, 1992, p vi, p 201.

54. S. Ayme, U. Faust, G. Fink, A. Gravanis, J. Martin-Moreno, LD Notarangelo, 1996 fiveyear assessment report of the biomedicine and health programme, European Commission, DGXII, 30 October 1996.

55. A.E. Baert and G.M. van Etten, The future of health and health services research, paper presented at the International and Interdisciplinary Meeting on the Future of health and health systems in industrialized societies, Bellagio, Italy, 27-31 May, 1985.

56. G. N Fracchia and M. Theofilatou, Health services research, Amsterdam: IOS Press, 1993.

57. WW Holland, The European Community atlas of 'avoidable death', 2nd ed., Vol I and II, Oxford University Press, 1991 and 1993.

58. A. Jamieson and R. Illsley (eds), Contrasting European policies for the care of older people, Gower: Aldershot, 1990.

59. M Casas and M. Wiley (eds), Diagnosis Related Groups in Europe, Berlin: Springer, 1993.

60. FFH Rutten and MF Drummond, Making decisions about health care technology: a costeffectiveness perspective, Institute for Medical Technology Assessment, Erasmus University Rotterdam and Centre for Health Economics: University of York, 1994.

61. Margaret Reid: The Diffusion of Four Prenatal Screening Tests across EC countries and Sweden, Stefan Kirchberger: The Diffusion of Two Technologies for Renal Stone 
Treatment across EC countries and Sweden, Michael A. Boss: The Diffusion of Heart and Liver Transplantation across EC countries and Sweden, in Barbara Stocking Series editor, A Study of the Diffusion of Medical Technology in Europe, London, King's Fund Centre, 1991.

62. D. Schwefel, R. Leidl, J. Rovira and MF Drummond (eds), Economic aspects of AIDS and HIVinfection, Berlin, Springer, 1990.

63. JC Jager and E Ruitenberg (eds), AIDS-impact assessment, modelling and scenario analysis, Amsterdam, Elsevier, 1992.

64. R. Leidl (ed), Health Care and its Financing in the Single European Market, IOS Press, 1998.

65. M. Belanger, L'espace sanitaire Europeen selon le Traite de Maastricht, Revue du Marche commun et de l' Union europeenne., no 372, Novembre 1993, p 785.

66. Resolution of the Council and the Ministers for Health, meeting within the Council, on future action in the field of public health, OJ No C 174, 25/6/1993.

67. Committee on the Environment, Public Health and Consumer Protection, Draft Report on public health policy after Maastricht, Rapporteur: Ken Kollins, EP 205.804, 9/7/1993

68. Commission communication on the framework for action in the field of public health, COM (93) 559 final, Brussels, 24 November 1993.

69. Proposal presented by the Commission for a European Parliament and Council decision creating a network for the epidemiological control of communicable diseases in the European Community, COM(96) 78 final, Brussels, 7.3. 96.

70. Commission of the EC, Report on the state of health in the European Community, $\operatorname{COM}(95) 357$ final, Brussels, 1995.

71. European Commission, The state of women's health in the EC, Luxembourg, 1997.

72. Commission of the EC, Second report from the Commission to the Council, the European Parliament, the Economic and Social Committee and the Committee of the Regions on the integration of health protection requirements in Community policies, COM (96) 407 final, Brussels, 4.9.96.

73. Speech by Jacques Santer, President of the European Commission to the European Parliament. Debate on the report by the Committee of Inquiry into BSE. Strasbourg, 18 February 1997

74. Hans Stein, The Treaty of Amsterdam and Article 129, A Second Chance for Public Health in Europe, Vol. 3, Number 2, Summer 1997, pp 4-8.

75. D. Evered, R. Kroes and E.C. Klasen (eds), Innovative research and appropriate health care for the citizens of Europe, Proceedings of the invitational conference on the occasion of the Netherlands' EU Presidency, 24-25 April 1997, Noordwijk and Zee, The Netherlands, European Commission, Eur 17786, 1997. 
76. Paper prepared by the Dutch Presidency of the European Union as a basis for discussion at the Health Council on 5 June 1997, Future Framework for Public Health, Eurohealth, Vol 3, No 2, Summer 1997.

77. The Lancet Editorial, Health Issues for Europe, The Lancet, Volume 343, Number 8892, January 29, 1994. 

8

Conclusions 
We developed an analytical framework to provide an insight into the Community involvement in health policy matters, the political perspectives and limitations that underlie it, and their likely impact on national health (care) policies and practices. We do not pretend that we covered all the health issues actually dealt with in the EC context or that we provided causal explanations of the actions of the actors involved.

We assumed that Community policy-making in the public health field would be embedded into Community institutions, rules and policy-making practices, influencing the manner in which issues emerge, policy is made, and the policy-making outcomes. Before analysing the content of activities in the health field, it was essential to understand the political structure of the EC, the policy-making role of the three main institutions and the rules governing law making and budgeting.

The foregoing chapters concentrated on the Community politico-institutional setting drawing theoretical and analytical guidance from the study of comparative international politics, European integration, and EC institutions, institutional rules and policy-making. The intention was to highlight the debate on the present European political structure in order to contribute to its understanding and eventually flesh out the significance of the constraints imposed by it on existing and potential Community public health agendas.

As for specific Community actions relating indirectly or directly to health, all chapters have been concerned with description and analysis of primary and secondary data. These data (Council directives, decisions, recommendations, conclusions, Commission policy documents, Parliament reports, indicative budget spending on public health activities and research programs) aimed at supporting the analysis of reasons for initiating action, priorities, and methods of implementation, with particular emphasis on the nature of the instruments involved (legal or financial). Analytical guidance was also drawn from publications, studies and reports dealing with the major issues at stake, examining EC action (or inaction), making concrete suggestions and more generally being part of the on-going debate on the future of health (care) policies in the Community.

The following conclusions emerge quite clearly from this study:

The Community is far from constituting a European public health sphere. There is nothing like a Europe-wide discourse on the key health issues on the European agenda. Health is far from being an issue in European elections. Citizens crossing national borders are still facing considerable difficulties with access to health services. The recent Court cases of $\mathrm{Mr}$ Decker from Luxembourg (who was refused the reimbursement of a pair of spectacles with corrective lenses purchased in Belgium) and $\mathrm{Mr}$ Kohll from Luxembourg (who was refused the reimbursement of his dental treatment provided by an orthodontist in Germany) clearly demonstrate this fact.

The Treaties, their institutional rules, and policy making practices, have allowed national governments to control the timing and shape of institution building as well as the division of powers between them and the Community in various policy areas including the health field. The framework of Community policy-making, clearly established in agriculture, trade, economic and monetary policy sectors, less clearly 
established elsewhere, is still lacking in areas of social policy, such as social security and health care. Nevertheless the Community powers bear weight in significant and sensitive areas of domestic health politics.

The Maastricht Treaty seemed to be largely about the single currency, constitutional issues and conflicting interpretations of the meaning of subsidiarity. Health issues remained peripheral. Nevertheless, the Maastricht commitment to public health provided Community competence in the fields of prevention and research. It added legitimacy to the existing public health activities and research programmes and arguments for developing new programmes and priorities. The Maastricht provisions have fallen well short of defining a common health and safety policy. It has fallen even shorter of introducing issues of health care policies, services and practices.

Yet, important health and safety matters have been in the Community agenda, debated daily in committee rooms, defined and redefined in various Commission departments and Councils of Ministers for Agriculture, Industry and the Internal Market, Environment, Employment, Social Affairs and so on. The BSE crisis forced to recognise the impact of the internal market legislation on public health. The revision of the public health article by the Amsterdam Treaty can be seen as an attempt to give back to Health Ministers the responsibility over the expanding Community health and safety affairs.

As health is a new policy, we cannot be conclusive about the specific patterns of policy making in the health field or the intentions and views of the actors involved. Health policy lacks a coherent institutional structure that would serve to focus debate, and articulate issues, conflicts, negotiation and choices. We can only expect that the new provisions may alter the legacy of an ad hoc and segmented approach into a more institutionalised planned framework to discuss health priorities and means for action.

Successful policy making in this field requires the recognition of the perennial disintegrative tendencies in the Community system, and the capability to take preventive and remedial action. The settlement of divisive health issues will require resolving serious disputes in a largely non-consensual multinational context. In such a context, policy-making tends to be dominated more by the search for acceptable compromises than for the solution of the problems. In a new policy area such as health, acceptable compromises will tend to be more concerned with the development of new institutional structures and ways to deal with the issues at stake, than with the health issues themselves. This is the fate of new policies, however.

In this study we placed the greatest emphasis on how issues have been introduced in the Community agenda. The chapters devoted to EC harmonisation policies, social policy, public health activities and research programs covered the emergence of a Community health agenda. Both the political discourse and the content of the European health agenda are very fragmented. Health is an example of fragmentation in the Commission as well as in the other Community institutions.

In the policy-making arena, we were only able to outline a pattern that can be found in other areas of Community action. According to the founding Treaty of the EC (Treaty of Rome), there is a specific pattern of Community policy-making in which the Commission would propose, the Parliament would advise and the Council would 
decide. The overall pattern of policy-making and the balance between the institutions may have remained the same. However, the recent Treaty changes sought to considerably increase the ability of the Community to adopt legal instruments in the health and safety field, and, to a far lesser extent, the financial resources corresponding to the binding regulations, the stated policy objectives of the ad-hoc public health programmes, and existing research activities.

Health issues were continuously introduced into the Community agenda through the Commission departments, which sought to use effectively the power of initiative to establish the single market as a legal basis for introducing new health legislation. Health issues may be introduced through the European Parliament as it seeks to test its new legislative powers and budgetary authority, influencing thus the allocation of the Community budget to support the introduction of new health activities. The European Court may also help, through expanding interpretations, to include issues of citizens, human, social or health rights. The European Council has introduced new health priorities as well. The Council of Ministers for Health and the Council for Research introduced issues and defined common problems. Still, the fragmentation of the health agenda turns out to be detrimental to the handling of issues over which there has already emerged a minimum consensus as to the need for their management at the Community level.

Market regulation lies at the centre of Community legislative activities linked to public health. The Community plays a governing role in regulating health, safety and more generally quality of life. From the point of view of health and safety considerations, it will take some time before the single market will be complete. As new environmental and consumer protection issues emerge, some member states will continue to enact regulations that will be perceived by other member states as non-tariff barriers to trade. These differences in national legislation can be seen as an important feature for agenda setting in the EC.

Even if this process serves to establish stricter Community-wide health and safety standards, the Community has neither a local administration, tribunals, nor controllers capable of enforcing implementation of directives or objectives, which frame European actions. The inadequacy of the system in protecting the health of European citizens from single market failures can be seen as a stimulus for changes in the organisational structure of Community as well as in national policy processes and administrative practices. At the beginning of the $90 \mathrm{~s}$, we witnessed the establishment of various European agencies such as the European Environmental Agency (Copenhagen), European Agency for the Evaluation of Medicinal Products (London) or the European Agency for Safety and Health at Work (Bilbao) and the European Agency for Drugs (Lisboa). Equally, we may witness the establishment of a European Agency for food safety.

Given that the Community budget represents a tiny fraction of national budgets, we do not expect a considerable increase in the Community funds for public health. The Community will continue to promote health data collection and transmission, experimentation in national health policy and seek to encourage the diffusion of public health activities and research programs, which have achieved some success. 
Despite the social provisions in the Treaty, Community competence in social security remained limited to the co-ordination of national systems to protect the social security rights, including health, of those exercising their right to free movement, the migrant workers and their families. The establishment of the single market and the single currency have always raised distribution and redistribution issues. Equally, discussions on the establishment of Community social security rights have always raised the difficult issues of: Community revenue and financing; the different situations in national labour markets; and national organisational and financial health (care) arrangements and benefits. The only concrete result has taken the form of an institutional structure to frame these discussions, the Agreement on Social Policy, for governments in the Council, the Commission, the UNICE (for industrial and employers' confederations in Europe), the ETUC (for the confederations of trade unions in Europe) and the CEEP (for public enterprises).

While the "right to health care" is not yet recognised at the Community level, national health (care) policies and systems will escape neither the direct nor the indirect consequences of Community decisions, be they the European single market or monetary union. Our tentative analysis of the strategic questions facing the national fiscal and budgetary policies in the prospect of EMU can only support this argument. Making sense of the implications of Community action on national health (care) policies and delivery systems will require informed and careful analyses of relevant domestic data.

Governments have voluntarily accepted to be bound by both the Maastricht convergence criteria and the Stability and Growth Pact in the Amsterdam Treaty, which include the threat of sanctions to countries running deficits above the $3 \%$ of GDP reference value. These rules introduce a major policy regime change in the making of national fiscal and budgetary policies and now dominate the EMU debate.

Among the emerging developments, of greatest importance is the fact that governments face different national concerns in relation to a variety of issues. Examples include the level of deficit and debt, employment and unemployment, the structure of social security financing and the level and quality of social security and health (care) services. From a purely national perspective, this generates questions about what kind of consequences the measures taken by governments may have for social security and health care.

At the European level, the Commission is currently co-ordinating a Community-wide reduction in government deficits. This will involve increasing pressures on governments to take measures aimed at reducing their budgetary imbalances. At the same time, the Community budget, which is now little more than $1 \%$ of Community GDP, is likely to be insufficient to counterbalance the undesirable consequences that these "corrective" measures may imply. The Community has been seen up to now as a secondary player in a health (care) reform process, which is still situated within the member states. Monetary union, if successful, would almost certainly force a revision of this judgement.

No strong predictions are possible about the implications of EMU on social security and health care. Whether predictions are optimistic or pessimistic, we must conclude 
that EMU creates pressures to reconsider the European social and health care model. Budgetary co-ordination must embrace fiscal stabilisation as the price for effective public agency, while rejecting economic and political auctions which would simply erode public sector spending, for instance, on social security benefits and health services.

"On any balanced view, the economic success of Europe in the 'golden age' of post-war expansion was supported by social settlements - in a variety of national forms - which gave legitimacy to political and economic leaderships and aligned the vast majority of citizens with their strategic decisions"'.

The political forces which identify with the underlying values of the European health model - solidarity and equal access to health care - are important everywhere. It remains to be seen whether they are capable of originating new forms of social solidarity, institutional rules, arrangements and programmes compatible with the bewildering complexity of European economic and monetary union.

\section{Chapter Eight References}

1. John Grahl and Paul Teague, Is the European Social Model Fragmenting? New Political Economy, Volume 2, Number 3, November 1997, pp 405-424, p. 423. 
Annexes 


\section{Annex One}

\section{MAASTRICHT TREATY}

\section{Article 129}

1. The Community shall contribute towards ensuring a high level of human health protection by encouraging co-operation between the Member States and, if necessary, lending support to their action.

Community action shall be directed towards the prevention of diseases, in particular the major health scourges, including drug dependence, by promoting research into their causes and their transmission, as well as health information and education.

Health Protection requirements shall form a constituent part of the Community's other policies.

2. Member States shall, in liaison with the Commission, co-ordinate among themselves their policies and programmes in the areas referred to in paragraph 1. The Commission may, in close contact with the Member States, take any useful initiative to promote such co-ordination.

3. The Community and the Member States shall foster co-operation with third countries and the competent international organisations in the sphere of public health.

4. In order to contribute to the achievement of the objectives referred to in this Article, the Council:

acting in accordance with the procedure referred to in Article $189 \mathrm{~b}$, after consulting the Economic and Social Committee and the Committee of the Regions, shall adopt incentive measures, excluding any harmonisation of the laws and regulations of the Member States;

- $\quad$ acting by a qualified majority on a proposal from the Commission shall adopt recommendations. 


\section{Annex Two}

\section{Treaty of Amsterdam}

\section{The Revised Article 129 (Article 152 in the new Treaty)}

1. A high level of human health protection shall be ensured in the definition and implementation of all Community policies and activities.

Community action, which shall complement national policies, shall be directed towards improving public health, preventing human illness and diseases, and obviating sources of danger to human health. Such action shall cover the fight against the major health scourges, by promoting research into their causes, their transmission and their prevention, as well as health information and education.

The Community shall complement the Member States' action in reducing drugsrelated health damage, including information and prevention.

2. The Community shall encourage co-operation between the Member States in the areas referred to in this Article and, if necessary, lend support to their action.

Member States shall, in liaison with the Commission, co-ordinate among themselves their policies and programmes in the areas referred to in paragraph 1. The Commission may, in close contact with the Member States, take any useful initiative to promote such co-ordination.

3. The Community and the Member States shall foster co-operation with third countries and the competent international organisations in the sphere of public health.

4. The Council acting in accordance with the procedure referred to in Article 189b, after consulting the Economic and Social Committee and the Committee of the Regions, shall contribute to the achievement of the objectives referred to in this Article through adopting:

a) measures setting high standards of quality and safety of organs and substances of human origin, blood and blood derivatives; these measures shall not prevent any Member State from maintaining or introducing more stringent protective measures;

b) by way of derogation from Article 43, measures in the veterinary and phytosanitary fields which have as their direct objective the protection of public health;

c) incentive measures, designed to protect and improve human health, excluding any harmonisation of the laws and regulations of the Member States.

The Council acting by a qualified majority on a proposal from the Commission, may adopt recommendations for the purposes set out in this Article.

Community action in the field of public health shall fully respect the responsibilities of the Member States for the organisation and delivery of health services and medical care. In particular, measures referred to in paragraph 4(a), shall not affect national provisions on the donation or medical use of organs and blood. 
212 


\section{Summary}

The book aims at developing an analytical framework to explain the role of the EC in health policy matters and the political perspectives and limitations that underlie it.

The recent formulation of public health may suggest that Community intervention in health issues is completely new. This study shows that the Community has always dealt with health issues since its creation in the fifties. How and why did the Community move into health issues? In which health issues does EC intervention happen and in which not? How can we explain the variations in policy development from one policy field to another? What judgement can one then come about the likely impact of the new Treaty provisions on public health? Our analysis of Community policy-making in health is based upon the assumption that potential Community public health agendas would be embedded into Community institutions, rules and policy making practices, which in turn influence the manner in which issues emerge, policy is made and the policy making outcomes.

Chapter one presents the rationale and objectives of this study and the layout of the book.

First we analyse the role of official institutions: the Council of Ministers and the European Council, the European Commission and the European Parliament. Chapter two points out several salient features of these institutions, paying attention to how they are involved in Community policy-making in health. In general terms, it may be said that rules governing the relationships between those institutions, which were established by the Treaty of Rome in 1957, indicated a pattern of policy and policymaking in which the Commission would propose, the Parliament would advise, and the Council would decide. The general balance between the institutions has always remained the same. Yet, changes introduced by the Single European Act and the Maastricht Treaty altered the policy agenda of the EC, the locus of decision-making and the relationships between the three institutions. The Member States acting within the Council of Ministers retain the final powers in making policy decisions and legislation in the Community. For a large number of health policy related areas that are covered by this study, decision making in the Council relies now more on coalition building than on national vetoes for protection. These areas include legally binding acts such as directives related to medicines, environmental, consumer protection as well as occupational health and safety. The areas also include spending programs on public health and framework programs for research and technological development. The Council may accept or may not accept a proposal, but it cannot act without initiation by the Commission. The Commission is a body appointed by the member governments and has only an indirect representation through the European Parliament. The Commission's agenda-setting role clearly represents its most important policymaking function. The role of the Commission in policy implementation is limited. National bureaucracies have great powers over its implementation as it takes place in line with their administrative traditions. An emerging policy area such as health is an obvious example of fragmentation within the Commission and in the other institutions as well. For example, the Directorates concerned with internal market; the 
environment, consumer affairs, social affairs and research prepare the proposals related to health matters. Therefore, health issues may be defined in a way that best suits one organisation or another. The European Parliament, directly elected since 1979, is the only institution based on direct popular legitimacy. The absence of a legislative function has impeded any major impact on the establishment of policies until recently. The lack of coherence of most of the party groups and internal majority requirements further constrained the development of party-ideological positions on EC policy choices. However, the Single European Act and the Maastricht Treaty increased the Parliament's powers over a range of policy issues, including health policy issues. In addition, the Parliament has increasingly sought to involve itself in a conscious strategy of agenda setting. Its Committee on the Environment, Public Health and Consumer Protection has a good reputation in doing so. Chapter two also contains a brief description of the European Court of Justice. Its role has been often associated with the process of 'constitutionalisation' of the Community Treaty. While the Court's ability to make policy is non existent, through judicial interpretation, it fills gaps in law and creates new laws in relation to many policy fields of apparent, restricted and marginal Community competence. We refer to cases concerning the health and safety of goods, the social security entitlements of migrant workers, and the provision of medical goods and services to insured persons within the Community, even without prior authorisation of the insured person's national social security institution.

Chapter three provides a brief insight into the nature of legal acts (regulations, directives, decisions, recommendations and opinions), the institutional procedures for their adoption and the budgetary resources at the Community's disposal in the health field. With respect to the adoption of legally binding acts in the health field, we describe and analyze three legislative procedures: the consultation procedure, the cooperation procedure and the co-decision procedure. The workings of the consultation procedure apply to the Treaty provisions relating to social security rights of migrant workers and their dependants. Since the establishment of the Community and up until today the Council adopts the legal measures (regulations) by a unanimous vote in the social security field and the Parliament is asked only for an opinion and on only one occasion. In the $1980 \mathrm{~s}$, the co-operation procedure accelerated the adoption of legally binding acts such as directives related to medicines, the environment, consumer protection as well as occupational health and safety. We discuss in detail Community task expansion into health legislation in chapter five. Today, the workings of the codecision procedure cover the adoption of directives relating to the internal market as well as the adoption of action programs in public health, consumer protection, the environment and the general framework program for research. In contrast to the act adopted by the latter procedures, which is an act of the Council, the act resulting from co-decision is adopted jointly by the European Parliament and the Council. It is a very complex procedure, but it increases the influence of the European Parliament over the establishment and the content of policies, which in the past has been very limited. The power of the Community to use legal instruments may have increased. The power to use financial instruments is modest and relatively new. In essence, the budget for health is subject to the overall limitations of the Community budget. Despite a significant upward trend in the 1980 s, the Community budget remains much smaller than national budgets. It is not concerned with social security. Public health is not even 
mentioned as a specific budget item. Some public health programs and research activities are supported by the Community budget. Chapter seven reviews the development of these activities and the money involved.

Our analysis of the Community's institutions is completed in Chapter four, which addresses the question, what kind of political organization is the Community? Two theoretical perspectives to the study of Community politics are differentiated: International Relations and Comparative Politics. International Relations see Community integration and policy-making within the context of relationships between nation-states. Attention is paid to their main theoretical propositions, especially those of neo-functionalism and intergovernmentalism. Neo-functionalism represents the first theoretical effort to explain and predict task expansion - that is, the movement from the removal of barriers to trade to the pro-active co-ordination of common policies in order to fulfil economic and welfare objectives. A central role is envisaged for supranational institutions, in particular the Commission, in the Community policymaking process as well as task expansion. The alternative approach, often labelled as the intergovernmentalist (realist) perspective, emphasises the dominant role of the Member States in the integration process. The Community is conceptualised as an international rather as than a supranational entity. In this perspective, the governments of the Member States and indeed the Council of Ministers dominate policy-making. Early realist interpretations of the EC helped also to focus attention on the significance of the differences in the national circumstances, cultural experiences and institutional practices of the countries engaged to integrate. The Comparative Politics approach does not conceptualise the Community as a process of interactions between NationStates but rather as a (partial) polity of its own. Having accepted that the Community does represent a new level of governance, successive commentators suggest the use of concepts and principles deriving from the study of the nation state to analyse Community politics and policy-making. We find that comparisons provide a useful way to better understand the classical political questions related to the governance that the Community must solve in order to develop further in the future. We also find that comparisons help us to better understand Community policy- making. Apparently, the Treaties are not constitutions. Norms, rules and decision- making procedures may exist, but the Community authority is still actively contested and the balance between Community and national authorities unsettled. Comparative analysis points out that, even in Community policy sectors operating within a relatively well established consensus, the principles are in dispute, the rules are not yet defined or are constantly redefined and the objectives hotly contested. While this also applies to Community policy-making in the health sector, our analysis is faced with even more difficulties. Public health is a new field of policy. Thus, policy-making in this field lacks a coherent institutional structure to help to articulate issues, conflicts, negotiation and choices, and thus focus the debate. Patterns of policy-making in the health field are also markedly different from those in the Member States because the issues at stake are different. The financing of social security programs, "the right to health care", the access to available or new health services, their financing and organization, all are predominant issues within national agenda. Whether proposals are based on Article $100,100 \mathrm{a}$ or other specific articles, we find in chapter five that health and safety issues dominate Community health agendas mainly through their limits to the regulation of 
the internal market program. The initial decision to create the common market did (as neofunctionalits argued) set in motion a dynamic process of functional spillovers into the field of health and safety legislation. Historically, it has been health considerations that justified differences in national market regulations. It was imperative to harmonise national legislations which represents the primary instrument of functional spillovers into fields such as medicine, the environment, consumer protection as well as occupational health and safety. Issues of harmonisation of social security and the establishment of Community social rights (and health rights) were within the Treaties, but largely in non-specific and conditional terms. Apparently, the social provisions did not set in motion a dynamic process of functional spillovers into social security and health care policies. In chapter six, we find that Governments responded in both pragmatic and symbolic ways to the social consequences of economic integration. By "pragmatic" we mean the establishment of the structural and cohesion funds in the 1980s. Greater scope to Community intervention was seen not so much in terms of regulating social (health) rights, but in terms of promoting economic development in the less developed regions of the EC. By "symbolic" we refer to fundamental social rights and in particular the Social Charter. The Social Charter, which became the Agreement on Social Policy (the Social Protocol) in the Maastricht Treaty, and finally was integrated by the Amsterdam Treaty, establish an institutional framework for governments, Community institutions, trade unions and employers, which may help to focus debate around social security issues. We also find that this structure is not suitable for clarifying the implications of monetary union, the convergence criteria and associated rules for budgetary policies, for national social security systems and health policies. The Maastricht public health provisions codified the lack of consensus over Community policy in health care by explicitly excluding Community intervention in the financing and organisation of health (care) services. In chapter seven we find that the new public health provisions codified the consensus and added legitimacy to the existing Community policy responses in the field of prevention, health information, education and research. Since the early 1980s National Health Ministers have been meeting to discuss the problems they have in common, for example, cancer and AIDS. We find that the legacy of the past of the two public health programs (cancer and AIDS) is full of conclusions, resolutions, ad hoc political mandates to the Commission, and the availability of only a modest amount of financial resources. In comparison to public health activities, research was given priority in budgetary terms. If we look back in the history of medical and health research programs we also find a similar pattern of policy development, a long period of argument and negotiation, as in the public health field. A relatively well established institutional structure such as the Framework program helped to better articulate the issues and thus focus attention on European collaboration in medicine and health. No one really expected that the next revision of the treaty (the Amsterdam Treaty) would change the limited consensus over Community public health policy. The BSE crisis forced to recognise the impact of the internal market legislation on public health. The revision of the public health article can thus be seen as a response to this fact. Health and safety matters, which were dealt with by Councils of Ministers for Agriculture, Industry and the Internal Market, are now responsibility of the Council of Ministers for Health. The revision can 
also be seen as an attempt to give back to Health Ministers the responsibility over the expanding Community health and safety affairs.

Finally, chapter eight picks up some of the observations and conclusions of the preceding chapters. Given the constraints and limitations of Community budget, we do not expect a considerable increase in the Community funds for public health. As health is a new policy, we cannot be conclusive about the specific patterns of policy making in the health field or the intentions and views of the actors involved. We can only expect that the new provisions may alter the legacy of an ad hoc and segmented approach into a more institutionalised planned framework to discuss health priorities and means for action. Under these circumstances, even modest financial increases might make a significant difference in relation to a new policy such as health.

Successful policy-making in this field requires the recognition of the perennial disintegrative tendencies in the Community system, and the capability to take preventive and remedial action. The settlement of divisive health issues requires resolving serious disputes in a largely non-consensual multinational context. In such a context, policy-making tends to be dominated by the search for acceptable compromises than for the solution of the problems. In a new policy area such as health, acceptable compromises will tend to be more concerned with the development of new institutional structures and ways to deal with the issues at stake, than with the health issues themselves. This is the fate of new policies, however. 



\section{Curriculum Vitae}

Maria Theofilatou was born in 1962 in the island of Kefallonia in Greece. She studied at Athens University from 1980 to 1985 where she gained degree in Economics. She got one year post-graduate training at the Athens' School of Public Health where she was granted the diploma of Hospital Administrator in 1988. She worked as a civil servant in social security at the Ministry of Health and Social Affairs from 1985 to 1987. She worked as a researcher at the Department of Sociology of the Athens' School of Public Health for October 1988 - February 1990. She then moved to Brussels to work as a national expert in the DG Research of the European Commission for February 1990 - February 1993. She has worked for one year in health technology assessment in the FAST programme and for two years in the field of Health Services Research in the Biomedical and Health Research programme. She then moved to The Netherlands to work as research fellow of Maastricht University- Faculty of Health Sciences from September 1993 to February 1995 and research fellow (onderzoeker) of the same University from January 1996 until July 1998. She lives in Brussels and she is currently working as a European civil servant at the Quality of Life Programme in the DG Research of the European Commission.

\section{Publications}

Theofilatou M., Social Security and Mental Health, Tetradia Psychiatrikis, Vol 24, November - December, Athens 1988, pp 21-34.

Fracchia G.N and Theofilatou M.(eds), Health Services Research Results of the 4th EC Medical and Health Research Programme, IOS Press, 1993.

Fracchia G.N and Theofilatou M., The European Community's research projects in the field of Health Services Research, International Journal of Technology Assessment in Health Care 9:4, 1993, pp 554-563

Theofilatou M. and Leidl R., Public Health Policy and Health Services Research in the European Union, in Laaser U, de Leeuw E., Stock C (eds), Scientific Foundations for a Public Health Policy in Europe, Juventa Verlag Weinheim and Munchen, 1995.

Theofilatou M. and Maarse J.A.M, Community harmonisation and Spillovers into Health Regulation, in Leidl R. (ed), Health Care and its Financing in the Single European Market, IOS Press, 1998. 
